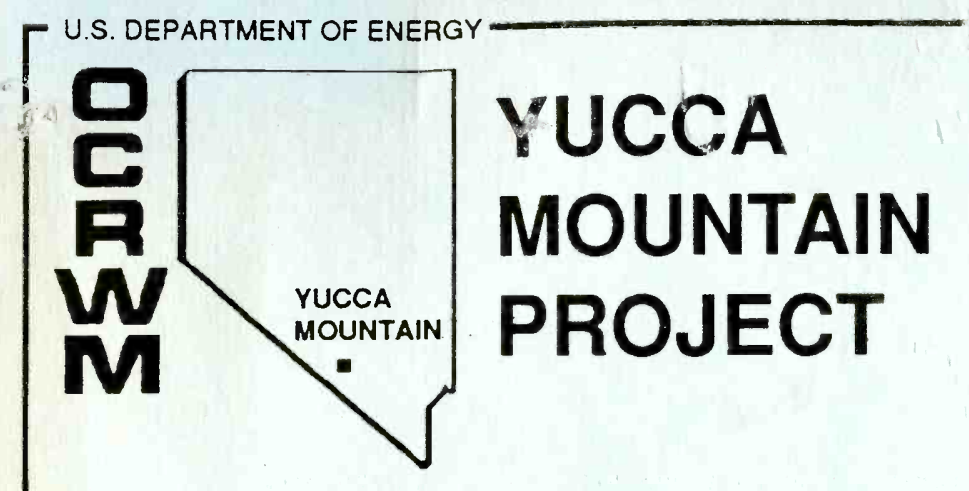

\title{
LITERATURE REVIEW AND ETHNOHISTORY OF NATIVE AMERICAN OCCUPANCY AND USE OF THE YUCCA MOUNTAIN AREA
}

INTERIM REPORT

JANUARY 1990

WORK PERFORMED UNDER CONTRACT NO. DE-AC08-87NV10576

Technical \& Management Support Services SCIENCE APPLICATIONS INTERNATIONAL CORPORATIŌN

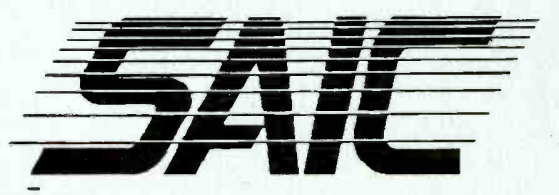




\title{
YUCCA MOUNTAIN PROJECT
}

\section{LITERATURE REVIEW AND ETHNOHISTORY OF NATIVE AMERICAN OCCUPANCY AND USE OF THE YUCCA MOUNTAIN REGION}

\author{
Interim Report \\ January 1990 \\ by \\ Richard W. Stoffle \\ John E. Olmsted \\ Michael J. Evans \\ Institute for Social Research \\ University of Michigan \\ Ann Arbor, Michigan \\ Prepared for
}

U.S. Department of Energy, Nevada Operations Office under Contract No. DE-AC08-87NV10576

by

Science Applications International Corporation Las Vegas, Nevada 


\section{Table of Contents}

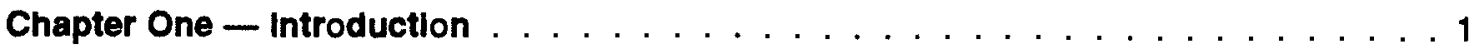

Repository Site Characterization . . . . . . . . . . . . . . . . . . . 1

Involved Indian Tribes . . . . . . . . . . . . . . . . . . . .

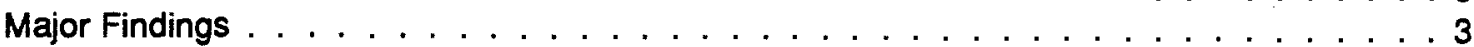

Organization of Report . . . . . . . . . . . . . . . . . . . . 7

Chapter Two - Summary of Methods and Effort . . . . . . . . . . . . . . . . . 8

Early Traveler Reports Analysis . . . . . . . . . . . . . . . . . . . . . . . 8

Government Documents Analysis. . . . . . . . . . . . . . . . . . . . . . . . . 8

Early Government Reconnaissance Expeditions . . . . . . . . . . . . . . . . . . . 8

Annual Reports of the Nevada Indian Agents . . . . . . . . . . . . . . . . . . . . . . . 9

United States Census . . . . . . . . . . . . . . . . . . . . . . . . 9

Reports of the U.S. Geological Survey and the Nevada Bureau of Mines . . . . . . . . . .9

Archaeological Surveys, Cultural Resource Surveys, and Planning Studies . . . . . . . .9

Nye County Documents . . . . . . . . . . . . . . . . . . . . . . . . . . . .

School Enrollment Records. . . . . . . . . . . . . . . . . . . . . . . . . . . .9

Ethnographic and Historical Documents Analysis . . . . . . . . . . . . . . . . . . 10

Ethnographic Literature. . . . . . . . . . . . . . . . . . . . . . . . 10

Historical Literature. . . . . . . . . . . . . . . . . . . . . . . . . 10

Unpublished Manuscripts . . . . . . . . . . . . . . . . . . . . . . . 10

Photographs . . . . . . . . . . . . . . . . . . 10

Local Newspapers Analysis. . . . . . . . . . . . . . . . . . . . . . . . . . 10

Visits to Archives in Nevada . . . . . . . . . . . . . . . . . . . . . . . . 13

Chapter Three - Natlve American Groups with Tles to the Study Area. . . . . . . . . 14

Traditional Native American Groups (Pre-1850) . . . . . . . . . . . . . . . . . . . . 14

Traditional Holy Land. . . . . . . . . . . . . . . . . . . . . . . . . . . . 14

Overlapping and Shared Territory. . . . . . . . . . . . . . . . . . . . . . 14

Ethnic versus Band Affiliation. . . . . . . . . . . . . . . . . . . . . . 15

Recent Native American Occupants (Post-1850) . . . . . . . . . . . . . . . . . . . . 18

Involved Native American Groups Based on Literature Search . . . . . . . . . . . . . . . 19

Contemporary Involved Native American Groups . . . . . . . . . . . . . . . . . . . . 20

Chapter Four - Summary of Native American Occupancy and Use . . . . . . . . . . 23

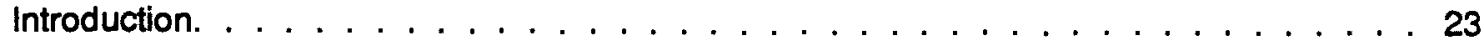

Native American Use Areas . . . . . . . . . . . . . . . . . . . . 23

Core Areas. . . . . . . . . . . . . . . . . . . . . . . 23

Permanently Occupied Springs . . . . . . . . . . . . . . . . . . . . 26

Areas of Seasonal or Temporary Use. . . . . . . . . . . . . . . . . . . . . . . . . . 27

Territories Encompassing All Three Kinds of Use Area . . . . . . . . . . . . . . . . . . 27

Major Factors and Vectors Affecting Native American Occupancy and Use Since Contact . 27

Disease . . . . . . . . . . . . . . . . . . . . 27

Violence . . . . . . . . . . . . . . . . . . . . . 28 


\section{Table of Contents (continued)}

Appropriation of Resources . . . . . . . . . . . . . . . . . . . . . . 28

Cultural Change . . . . . . . . . . . . . . . . . . . . 30

Place-by-Place Chronologies . . . . . . . . . . . . . . . . . . . . . . 31

Oasis Valley Core Area. . . . . . . . . . . . . . . . . . . . . . . . . . . . . . 31

Ash Meadows Core Area . . . . . . . . . . . . . . . . . . . . . . . . . . . . . . . 37

Pahrump Valley Core Area . . . . . . . . . . . . . . . . . . . . . . . . . . . . . . .41

Permanently Occupied Springs North and East of Yucca Mountain and

Fortymile Canyon. . . . . . . . . . . . . . . . . . . . . . .443

Yucca Mountain and Fortymile Canyon Area . . . . . . . . . . . . . . . . . . 48

Conclusion . . . . . . . . . . . . . . . . . . . . . . . . . 49

Chapter Five - Keyword Chronological Data Base . . . . . . . . . . . . . . . . 50

Introduction. . . . . . . . . . . . . . . . . . . . . 50 50

Pre-Contact and Early Contact Period, Undated . . . . . . . . . . . . . . . . . . 50

Late 1800 s and Early 1900s, No Exact Date . . . . . . . . . . . . . . . . . . . . . . . . 56

Post-Contact Period to $1900 \ldots \ldots \ldots \ldots \ldots$

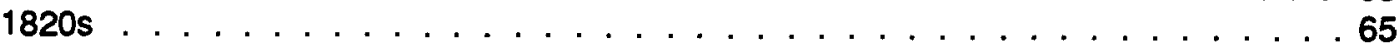

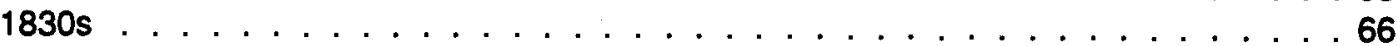

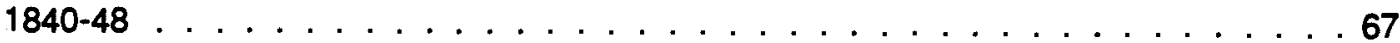

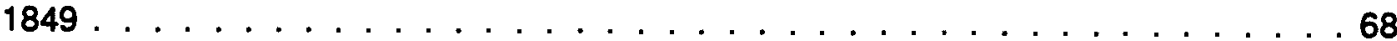



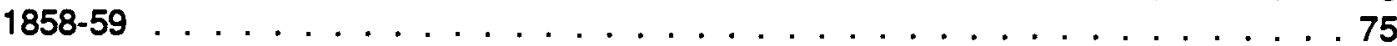

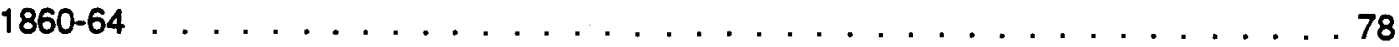

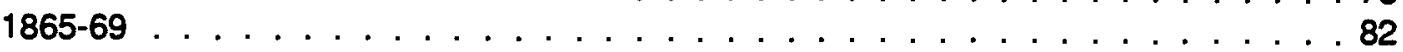

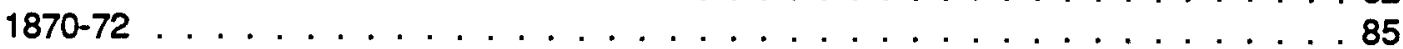

$1873-74 \ldots \ldots \ldots \ldots$

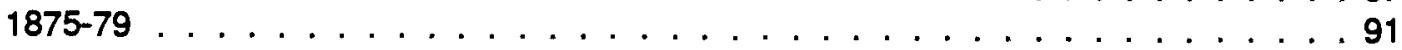

$1880-84 \ldots \ldots \ldots \ldots \ldots \ldots$

$1885-89 \ldots \ldots \ldots \ldots$. . . . . . . . . . . . . . . . . . . . . . . . . . .

$1890-91 \ldots \ldots \ldots \ldots$. . . . . . . . . . . . . . . . . . . . . . . . . . .

$1892-99 \ldots \ldots \ldots \ldots \ldots \ldots \ldots$

Post-Contact Period Since $1900 \ldots$. . . . . . . . . . . . . . . . . . . . . . 107

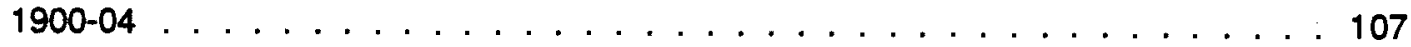

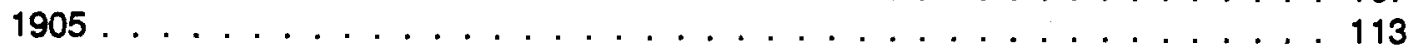

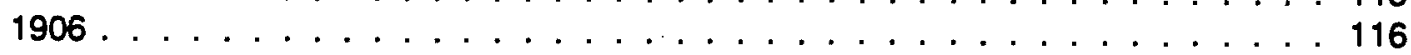

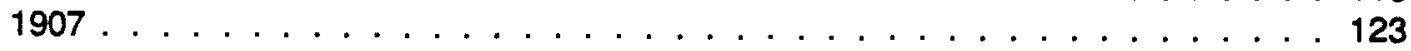

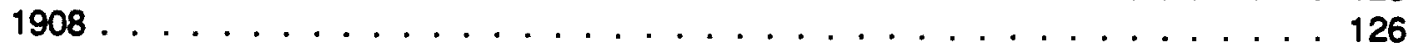



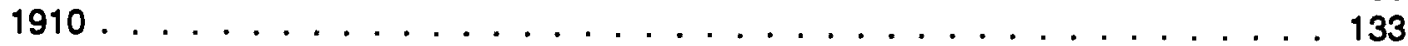

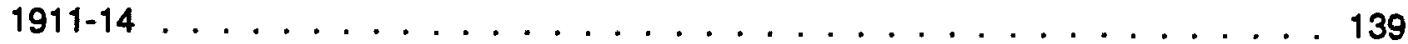



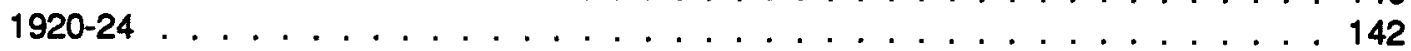

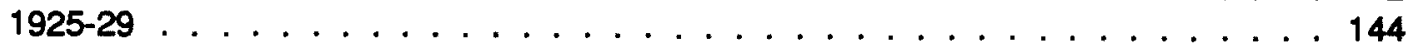




\section{Table of Contents (continued)}

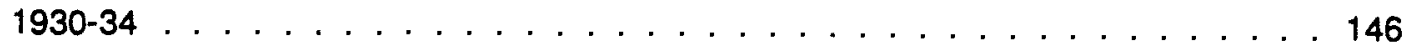

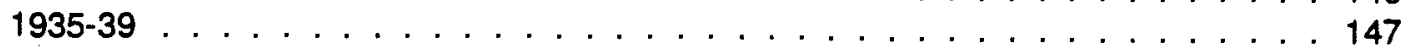

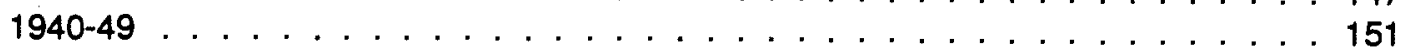

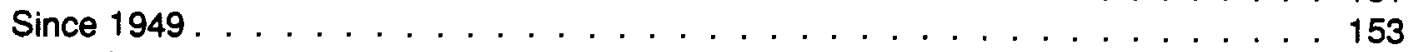

Twentieth Century, No Exact Date . . . . . . . . . . . . . . . . . . 155

Blbllography. . . . . . . . . . . . . . . . . . . . . 168

Books, Journal Articles, and Government Publications . . . . . . . . . . . . . . . . 168

Nye County Government Documents . . . . . . . . . . . . . . . . . . . . . . . . . . . 182

Unpublished Manuscripts and Taped Interviews . . . . . . . . . . . . . . . . . 183

Photographs . . . . . . . . . . . . . . . . . . . . . . . . . . 184

Newspaper Articles. . . . . . . . . . . . . . . . . . . . . 185 


\section{List of Tables}

Table

1 Number and Location of Indian People Involved in the Yucca Mountain

Cultural Resources Study. . . . . . . . . . . . . . . . . . . . . . . . . . . . 21

2a Documented Native American Occupancy or Use, by Place and Decade . . . . 24

2b Documented Native American Occupancy or Use, by Place and Decade . . . . . 25

3 Southern Paiute Tribal Groupings, Populations, Political Leadership and

Regional Links, 1870s . . . . . . . . . . . . . . . . . . . . . . . . . 89

41900 Census Data on Native American People in Southern Nye County . . . . 108

51910 Census Data on Native American People in Southern Nye County . . . . 134

\section{List of Illustrations}

Map

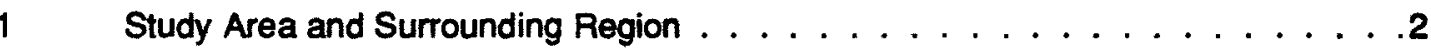

2 Traditional Ethnic Boundaries and Locations of Tribes Involved in the

Yucca Mountain Project . . . . . . . . . . . . . . . . . . . . . 4

Southern Paiute Bands . . . . . . . . . . . . . . . . . . . . . 16

Routes of the Forty-Niner Emigrants . . . . . . . . . . . . . . . 45

Routes of the Forty-Niners . . . . . . . . . . . . . . . . 46

Some of the Archaeological Sites on the Nevada Test Site . . . . . . . . . . 157

Springs, Settlements, Roads, and Railroads in Southwestern Nevada,

1909 . . . . . . . . . . . . . . . . . . . . . . . . . . . . 158

Ranches, Mines, and Settlements in the Amargosa Region, 1870-90 . . . . . 159

Towns, Mining Camps, and Railroads in the Amargosa Region, 1890-1910 . . . 160

Towns, Mining Camps, and Railroads in the Amargosa Region, 1910-33 . . . . 161

Photo

1 Native American Settlement at Bullfrog, Nevada, $1906 \ldots \ldots$. . . . . . . . . 162

2 Native American Camp, Rhyolite, Nevada, circa $1910 \ldots \ldots$. . . . . . . . . . 163

$3 \quad$ Native American Women in Fourth of July Foot Race in Rhyolite, 1908 . . . . . 164

$4 \quad$ Native American Residents of Rhyolite, 1907 . . . . . . . . . . . . . 165

$5 \quad$ Native American Women near Beatty, circa 1901 . . . . . . . . . . . . . . 166

6 The M.M. Beatty Family at the Beatty Ranch, circa 1905 . . . . . . . . . . . . 167 


\section{CHAPTER ONE}

\section{Introduction}

This report presents a review of the literature concerning Native American occupancy and use of the Yucca Mountain area and vicinity. It draws on a wide range of material, including early traveler reports, government documents, ethnographic and historical works, and local newspapers. The report complements two other concurrent studies, one focused on the cultural resources of Native American people in the study area and the other an ethnobotanical study of plant resources used by Native American people in the study area. Both concurrent studies are based on interviews with Native American people.

The literature review has had two principal purposes: to determine the completeness of the Yucca Mountain Native American study design (Stoffle, 1987) and to contribute to the understanding of the presence of Native American people in the Yucca Mountain area. A review of the existing literature about the Yucca Mountain area and southern Nye County, supplemented by the broader literature about the Great Basin, has verified three aspects of the study design. First, the review has aided in assessing the completeness of the list of Native American ethnic groups that have traditional or historical ties to the site. Second, it has aided in the production of a chronology of Native American activities that occurred on or near the site during the late nineteenth and early twentieth centuries. Third, it has helped to identify the location of cultural resources, including burials and other archaeological sites, in the study area and vicinity.

\section{Repository Site Characterization}

The Nuclear Waste Policy Act of 1982 proposed a plan to safely dispose of commercial power plant wastes, to conduct environmental investigations, and to involve Native Americans in site selection proceedings. A national search for a site where a high-level radioactive waste facility could be located culminated in the environmental assessment studies recommending three candidate sites for further consideration: Hanford, Washington; Deaf Smith County, Texas; and Yucca Mountain, Nevada. When the present study was initiated (June 22, 1987), the U.S. Department of Energy (DOE) was beginning site characterization activities at all three sites. The Nuclear Waste Policy Act, as amended in December 1987 by the United States Congress, now specifies that Yucca Mountain, Nevada, will be the only candidate site to be characterized.

Site characterization includes laboratory and field activities undertaken to establish the geologic and hydrologic condition of the site and the ranges of parameters needed to evaluate the suitability of the site as a potential location for a repository. In conjunction with site characterization, environmental studies are being conducted to assess how site characterization activities may affect the environment. The studies will form the basis for actions to minimize any significant adverse environmental impacts. The literature review and ethnohistory is one product of the Native American cultural resources study, which is part of this environmental research. The cultural resources study area is indicated in Map 1.

Science Applications International Corporation (SAIC), Las Vegas, Nevada, is providing support to the DOE for site characterization and environmental research at Yucca Mountain. SAIC subcontracted the Native American cultural resources study to anthropologists from the Institute for Social Research at the University of Michigan. 




Map 1. Yucca Mountain Cultural Resources Study Area (SAIC modification of DOE, 1986). 


\section{Involved Indian Tribes}

As outlined in the preliminary research design (Stoffle, 1987), the Native American cultural resources study pertains to three ethnic groups-Owens Valley Paiute, Southern Paiute, and Western Shoshone-whose cultural resources are found in the Yucca Mountain region. Ethnographic experiences in the southern Nevada area and an extensive literature review led to the selection of sixteen Indian tribes that potentially would be involved in the Native American cultural resources project. After meeting with each of the sixteen tribes, all requested that they be included in the project. Their involvement has included participating in in-depth ethnographic interviews, tribal council presentations, reviews of cultural resources project reports, and site visits to the Yucca Mountain study area.

The location of contemporary reservations for the sixteen Indian tribes and the approximate boundary of the Owens Valley Paiute, Southern Paiute, and Westem Shoshone ethnic groups in the late 1800s is presented in Map 2.

\section{Major Findings}

Documents examined in the literature review reveal that the study area and vicinity are most usefully thought of as comprising three different types of Native American use areas. There are (1) core areas of permanent Native American occupancy to the west and south of Yucca Mountain (Oasis Valley, Ash Meadows, and Pahrump Valley), (2) permanently occupied springs to the north and east of Yucca Mountain (Captain Jack Spring, Whiterock Spring, Oak Spring, Tippipah Spring, and Cane Spring), and (3) areas of seasonal and temporary use (Yucca Mountain, Fortymile Canyon, Timber Mountain, and Pahute Mesa).

Documents examined in the review dispel any notion that the Native American population disappeared or dwindled to insignificance after Euroamericans settled in the region.

Documents show that Native American people continued to occupy permanent villages, settlements, and homesites in core areas in the vicinity of Yucca Mountain throughout the postcontact period (up to the present in the case of Oasis Valley and Pahrump Valley and through at least the 1950s in Ash Meadows). In the core areas adjacent to the study area, Euroamericans appropriated many of the springs, but Native American people retained use of some of the springs well into the twentieth century. Native American people continued to own and operate a few farms and ranches well into the twentieth century in Oasis Valley and Ash Meadows, in addition to working on Euroamerican-owned farms and ranches. Documents show that as late as the 1930s Native American people comprised a substantial portion of the population in Oasis Valley and in southern Nye County generally. Documents also indicate that Native American people continued to reside seasonally or year-round at some of the springs to the north and east of the study area through at least the 1930s.

Native American people continued to use seasonal and temporary use areas, including Yucca Mountain and Fortymile Canyon, well into the post-contact period. However, events in the Yucca Mountain area and in the adjoining areas of Fortymile Canyon, Timber Mountain, and Pahute Mesa are poorly documented in Euroamerican documentary sources. This is not surprising, because the general area remained a forbidding, arid, back country zone for most Euroamericans-a zone that has never had any substantial permanent Euroamerican settlement. The results of the literature review suggest that for information on Native American 


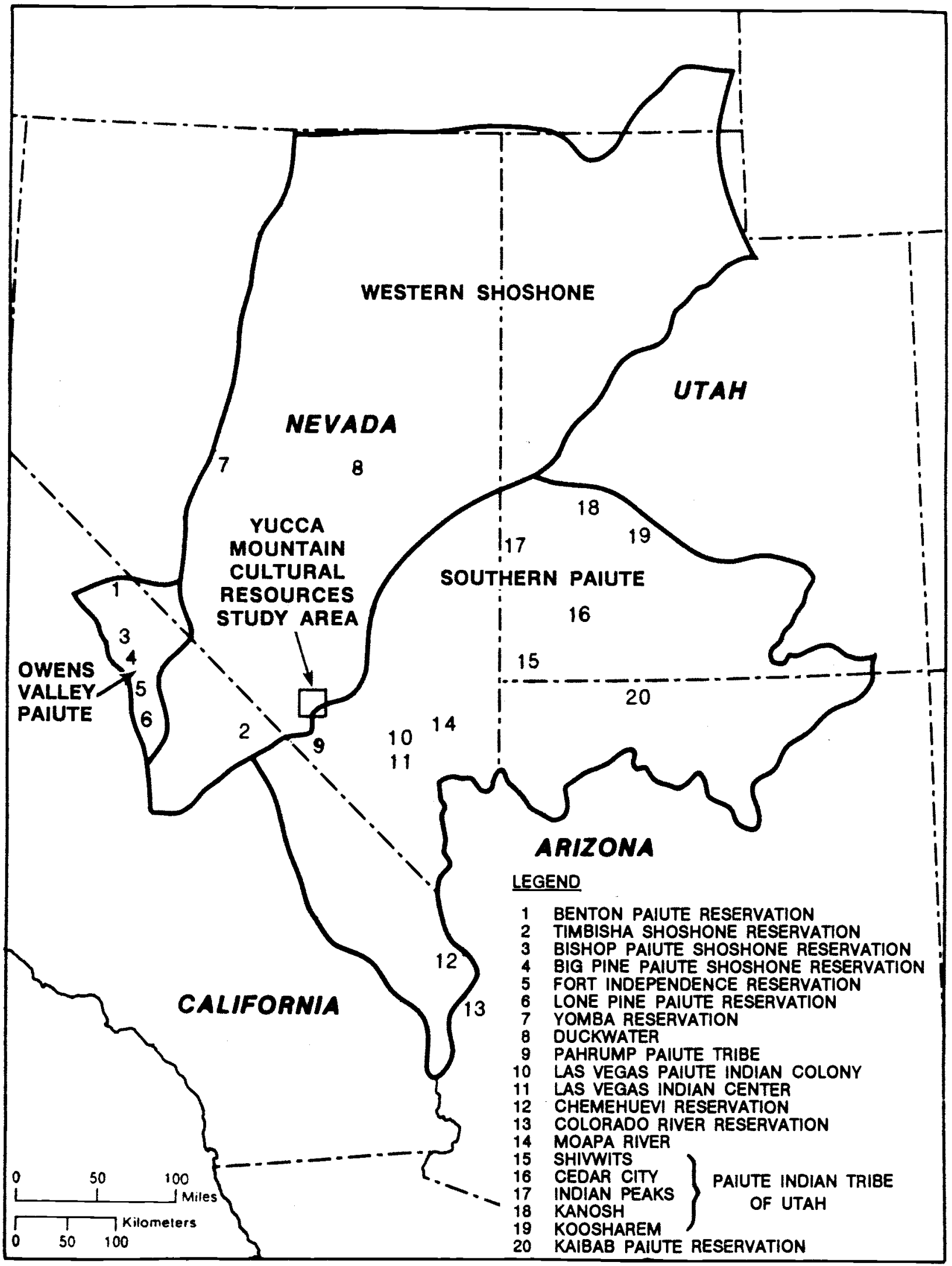

Map 2. Traditional Ethnic Boundaries and Locations of Tribes Involved in the Yucca Mountain Project (adapted from D'Azevedo, 1986). 
occupancy and use in the Yucca Mountain area itself, ethnographic interviews with Native American people must be the primary source. However, the literature review does provide abundant documentation for continued occupancy of Native American people in the surrounding core areas, as well as documentation that these Native American people have continued to practice traditional activities throughout the post-contact period, activities that take them into temporary and seasonal use areas like Yucca Mountain. Documents show that people in the Oasis Valley area and in Pahrump Valley continued to harvest and use medicinal plants, wild food plants, and basketry plants through at least the late 1930s, and to derive part of their cash income as well as part of their non-cash livelihood from these sources. Documents show that most of the jobs and occupations filled by Native Americans in the Euroamerican economic sector through at least the 1930s were temporary, seasonal, or intermittent, enabling Native American people to continue their traditional transhumant adaptive pattern of leaving the core areas to inspect the progress of plant and animal crops to be harvested later; to harvest pinyon nuts, seed grains, medicinal plants, and game; and to participate in social events. The literature review also documents that Native American people in the vicinity of Yucca Mountain were actively involved in mineral prospecting well into the twentieth century, another activity that took them into seasonal and temporary use areas like Yucca Mountain. It should be noted that Native American people played a significant part in the development of mining in southern Nye County.

The literature review indicates that Native American people in the study area and vicinity early adopted many Euroamerican cultural elements, while retaining most of their traditional culture. They early adopted the use of industrially produced clothing and other industrially produced goods. This adoption poses a problem for interpreting post-contact archaeological sites in the study area. Native Americans occupying a rock shelter or cabin in the early twentieth century, for example, would have left much the same kind of debris as a Euroamerican prospector using the same site. While adopting a wide range of Euroamerican goods and techniques, and learning sufficient English to take jobs in the Euroamerican economic sector, Native American people retained most of their traditional culture, and continued to harvest a wide range of wild plant and animal crops, to harvest and use traditional medicinal plants, and to produce and use traditional implements like baskets.

The review indicates that several of the earliest Euroamerican settlers in the vicinity of the study area married local Native American women. These intermarriages enabled Euroamerican settlers to secure allies and to gain access to local indigenous knowledge of climate, topography, water sources, wild food sources, and mineral resources. These intermarriages and their "mixed blood" descendants were important in the development by Native American people of a new cultural synthesis of Native American and Euroamerican cultural elements. Intermarriages between Native Americans and early Euroamerican settlers and the children of these marriages were also important in enabling Native American and Euroamerican ethnic groupings to achieve a modus vivendi of coexistence.

Native American people from outside Nevada were among the wave of immigrants who settled in the vicinity of the study area in the late 1800 s and early 1900 s. The 1900 census recorded a family in which the three children were identified as half-Indians born in North Carolina. Correspondence and documents left by Indian Agent Lorenzo D. Creel indicate that a Cherokee man settled at Ash Meadows in the early 1900 s and lived there through at least the early 1920s. 
Documents analyzed in the literature review indicate that Native American burials have been excavated in the study area and vicinity - at Cane Spring and in the Pahute Mesa areaand that there are numerous Native American archaeological sites throughout the study area. Artifact assemblages from some of the rock shelters and other sites suggest Native American occupancy well into the post-contact period.

Aboriginal agriculture, with corn and squash as the major crops, was evidently practiced at Ash Meadows, Cane Spring, and Pahrump Valley, as attested by early traveler reports, reports of early Indian Agents in Nevada, ethnographic studies by Steward (Steward, 1938; Steward, 1941), and recent research by Lawton et al. (1976). After Euroamerican settlement, Native American people in the vicinity of the study area continued to farm, both as farm laborers and on their own behalf-both for subsistence use and for commercial sale.

Several limitations of the documentary data must be noted. These shortcomings of Euroamerican documents underscore the importance of ethnographic interviewing as a source for information about Native American occupancy, use, and cultural resources in the study area.

One important limitation has already been mentioned: Euroamerican sources provide very limited information about Native American occupancy and use in the Yucca Mountain area. This limitation is not surprising because there has never been substantial, permanent Euroamerican settlement in the immediate area. As one moves farther from Yucca Mountain, into the Oasis Valley area, there is much better documentation for some periods, particularly the period between 1905 and 1912, when there were several mining boomtowns and newspapers in the Oasis Valley area. Likewise, in the Ash Meadows area there was a greater concentration and continuity of Euroamerican settlement, and thus more developed Euroamerican documentary sources. Oasis Valley newspapers and newspapers published in more distant locations provide some coverage of the study area, but the coverage is very limited. One cannot move from the dearth of documentation concerning the Yucca Mountain area in Euroamerican sources to a conclusion that Native Americans did not continue to occupy and use the Yucca Mountain area. Rather, one must acknowledge that Euroamerican sources provide very limited data concerning Native American occupancy and use in this particular area.

Second, many Euroamerican observers, particularly in the early contact period, failed to make discriminating distinctions between different Native American ethnic groupings. Native American people in the region were often indiscriminately grouped together under the term "Piute," "Digger," or simply "Indian." Thus, in many documents the term "Piute" is apparently used indiscriminately to refer to Shoshones as well as to Paiutes.

Third, many sources with potentially relevant data concerning the study area remain beyond the scope of this literature review, particularly in terms of newspapers with coverage of the study area and vicinity. The review has attempted to identify and examine basic references relevant to understanding Native American occupancy and use in the Yucca Mountain area, but particularly in the category of local newspapers with coverage of the study area, the authors achieved a sampling rather than a complete examination of all the relevant sources. There are hundreds of additional reels of newspaper microfilm with varying degrees of coverage of the study area that have not been examined. The literature review effort included only limited searching of newspapers in the more recent period since the withdrawal of the study area from public use. However, it is clear that Native American people continued to use the study area even after the area began to be progressively withdrawn from public use. 


\section{Organization of Report}

A summary of methods and effort is presented in Chapter Two. Literature review findings related to the study design are then presented in the next three chapters. Chapter Three discusses Native American groups that may have traditional or historic ties to the site. Chapters Four and Five present a chronology of occupation and use of the study area and southeastern Nevada by Native American groups. Chapter Four summarizes and analyzes the data concerning chronology, in terms of (1) major factors and vectors of change and (2) place-by-place chronologies for Oasis Valley, Ash Meadows, Pahrump Valley, permanently occupied springs north and east of Yucca Mountain, and the Yucca Mountain and Fortymile Canyon area. Chapter Five provides a detailed data base conceming occupancy and use, organized chronologically and indexed by keywords. The Bibliography is organized into several sections: (1) books, journals, articles, and government publications; (2) unpublished manuscripts and taped interviews; (3) newspaper articles; (4) government documents; and (5) photographs.

Data regarding the chronology of Native American occupancy and use obtained through the literature review are thus presented in several ways: (1) organized by place, in Chapter Four (Summary); (2) analyzed in terms of different factors or vectors of change, also in Chapter Four (Summary); (3) organized by date, in Chapter Five (Keyword Chronological Data Base); (4) organized by keywords, also in Chapter Five (Keyword Chronological Data Base); and (5) organized by source and author, in the Bibliography. 


\section{CHAPTER TWO}

\section{Summary of Methods and Effort}

This chapter discusses the methods utilized in the literature review and takes note of the extensive body of relevant literature that remains to be examined.

The review of the relevant literature on the Yucca Mountain area examined four major categories of documents: (1) early traveler reports, (2) govemment documents, (3) ethnographic and historical documents, and (4) newspapers. In each instance, the first step in the analysis was an effort to determine the extent of available materials in each of these categories. Then a non-random sample of documents was acquired to assess the quality of data available in the different types of sources. Finally, a subset of documents, usually stratified by time period, were intensively searched for data relevant to the Native American study design topics discussed in the previous chapter. The literature search was begun on June 22, 1987.

\section{Early Traveler Reports Analysis}

Early traveler reports encompass diaries and other records of travelers from the 1820 s through the 1850s. The multivolume series edited by Hafen and Hafen (1954-61) was pivotal as a starting point for accessing and analyzing early traveler reports. The series contains numerous reports and diaries written by early travelers along the Old Spanish Trail, by travelers who crossed the study area in 1849, and by travelers on other expeditions in the area, as well as commentary by the editors. Also important as a starting point was Lingenfelter (1986) for its wealth of citations and the bibliographic entries. Citations and the bibliography in Lingenfelter (1986) identified many early traveler reports and analyses of early traveler reports published in the decades since the publication of the Hafen and Hafen series. Another important starting point were the articles and bibliography in D'Azevedo (1986).

Several recent studies examine the passage of a few parties of transcontinental travelers through the study area in 1849, parties now generally referred to as the "Jayhawkers" (Johnson and Johnson, 1987; Nusbaumer, 1967; Koenig, 1984). These works reprint the diaries and reports of people who traveled through the Nevada Test Site area and Fortymile Canyon.

\section{Government Documents Analysis}

The category of government documents searched and analyzed encompasses several distinct subgroupings. These subgroupings are discussed in the following sections.

\section{Early Government Reconnaissance Expeditions}

Reports of early government reconnaissance expeditions in the study area include the 1859 expedition led by John W. Davidson (Wilke and Lawton, 1986), the 1869 and 1871 expeditions under the leadership of George M. Wheeler (Wheeler, 1871, 1875), and the reports of ethnographic research by John Wesley Powell and G.W. Ingalls in southem Nevada in 1869 (Powell and Ingalls, 1874). 


\section{Annual Reports of the Nevada Indlan Agents}

The annual reports of Nevada Indian Agents were published for some years in the annual reports of the Secretary of the Interior. For other years, the reports were published in the Executive Documents Series of the House and Senate.

\section{United States Census}

Not all the U.S. census records for Nevada are available for the years since 1864, when Nevada became a state. The 1870 and 1880 census records do not enumerate Native American people. The 1890 census rolls have been destroyed. The Nevada census records for 1900 and 1910 include detailed enumerations of Indian individuals in southern Nye County, with data on personal names, ethnic grouping, tribal affiliations, occupations, housing, and language. The detailed enumeration for later censuses are sealed; the 1920 and 1930 census rolls, for example, will remain sealed until 1992 and 2002, respectively.

\section{Reports of the U.S. Geological Survey and the Nevada Bureau of Mines}

The principal sources in this category were Ransome (1907) and Mendenhall (1909). Reports from the Nevada Bureau of Mines were also important (Kral, 1951; Cornwall, 1972).

\section{Archaeological Surveys, Cultural Resource Surveys, and Planning Studies}

Several archaeological surveys, cultural resource surveys, and planning studies for Yucca Mountain, the Amargosa region, and the Death Valley region were used in the literature review. Sources included Worman (1969); Pippin, Clerico, and Reno (1982); Pippin (1984, 1986); DOE (1986); Greene (1981); Kensler (nd); and Busby, Findlay, and Bard (1979).

\section{Nye County Documents}

Nye County documents are located at the Nye County Courthouse in Tonopah, Nevada. Relevant materials include records of court proceedings in criminal and civil cases, reports of inquests, and oaths of office. Two visits to the Nye County Courthouse were successful in locating records of proceedings for a limited number of the court cases and inquests for which names of defendants and judges had previously been identified. Many of the documents sought have apparently been lost, although they are listed on the ledgers with accompanying file reference numbers. Local interviews in Beatty identified Native American people who had been employed as sheriff's deputies, and their oaths of office were obtained from the Recorder's Office in the Nye County Courthouse.

\section{School Enrollment Records}

An effort was made to obtain enrollment data for the Beatty school system from the early 1900 s through the 1940s, in order to document the cohort of Native American students. Unfortunately, neither the District School Offices in Tonopah nor the Beatty School had retained any ledgers for this period. A former Beatty School teacher indicated she had retained ledgers for the 1938-39 school year, but she was unable to locate them. Photographs and oral histories document that Native American students comprised a substantial fraction of Beatty School students through at least the late 1930s. 


\section{Ethnographic and Historical Documents Analysis}

The category of ethnographic and historical documents searched and analyzed encompasses several distinct subgroupings. These subgroupings are discussed in the following sections.

\section{Ethnographic Llterature}

D'Azevedo (1986), written by a recognized authority on Great Basin Indian tribes, was a key starting point in identifying the relevant literature in this category. Also important were searches through recent decades of the Journal of California Anthropology, the Journal of California and Great Basin Anthropology, and the Ballena Press Publications in Archaeology, Ethnology, and History.

\section{Historical Literature}

Historical literature includes published materials on the history of mining, mining towns, and railroads in southern Nye County. Among the important points of access to this literature were Lingenfelter (1986), catalogs and indexes at the Nevada Historical Society and at the University of Nevada-Reno's (UNR's) Special Collections Department, Elliott and Poulton (1963), and cultural resource studies (Stoffle and Dobyns, 1982; Stoffle, Dobyns, and Evans, 1983). Unfortunately, the key source for information on railroads in the area (Myrick, 1962) provides neither citations nor leads toward more detailed documentation of railroad-related activities in southern Nye County.

\section{Unpublished Manuscripts}

Several sources, including Lingenfelter (1986), the catalogs and indexes of the Nevada Historical Society, the University of Nevada Oral History Program, and the UNR Special Collections Department, were important in the identification of potentially relevant unpublished manuscripts written by residents of and visitors to southern Nye County. The UNR Special Collections Department's "A Guide to the Lorenzo D. Creel Collection" led us to correspondence by Indian Agent Lorenzo Creel concerning Native American people and Native American claims to water in the Ash Meadows area.

\section{Photographs}

Photographs can often be a useful source of relevant historical data. The authors searched two photograph collections: those of the Nevada Historical Society and of the Central Nevada Historical Society.

\section{Local Newspapers Analysis}

Analysis of newspaper coverage of events in the southern Nevada region provided a wealth of information about Native American people in the area and their activities. The pivotal starting point for the newspaper search was Lingenfelter and Gash (1984), supplemented by a similar earlier work by Folkes (1964). Lingenfelter and Gash (1984) identifies all the newspapers published in Nevada and in adjacent counties of neighboring states, organized by geographic location; gives the dates of publication; and provides fairly accurate information about locations of microfilm copies of newspapers, if copies are extant. These reference works made it possible to (1) identity the newspapers published in towns closest to the 
study area for each period of time, (2) identify which newspapers were available at what libraries, and (3) select a suitable sample of newspapers from different time periods and locations.

The specific search procedure varied from one newspaper to the next. Most of the newspapers searched consistently devoted one or two inside pages to local and regional news items, with other pages devoted to national and intemational news and to nationally syndicated columns. Once the pattern had been identified for a particular newspaper, typically only the front page and the local news page or pages needed to be searched. In their search, the authors looked for articles mentioning Native American people, locations in or near the study area, or events in which mention of Native American involvement was likely, such as public celebrations on major holidays. The authors also searched through the columns dedicated to local and regional news.

Since Nevada libraries are the sole sources for most of the Nevada newspapers involved in this search, the initial phases of the newspaper search were conducted via interlibrary borrowing. A field visit to archives in Nevada was crucial for the newspaper search, making it possible to search or sample a large number of newspapers over a wide range of years.

There is no single best newspaper source that covers the study area from the inception of the first newspapers in Nevada through the increasing restriction upon use of the study area in the period since 1940. For each period of time, the search effort focused on newspapers published in the towns that are (or were) nearest the study area, often enhanced by a limited sampling of newspapers from more distant parts of Nevada. In addition, many relevant newspaper articles were identified via citations in books and articles. These newspaper articles were then searched out and photocopied.

Nevada's first newspaper was the Territorial Enterprise, which began publication in 1858, initially in Genoa, then in Carson City, and then in Virginia City. No searches were conducted in newspapers published this far from the study area, as a matter of prioritizing effort.

For the period from 1870 to 1901 , the Nevada newspapers located nearest the study area were published in Pioche, Belmont, De Lamar, and Tybo. Califomia newspapers located at an only slightly greater distance were published in Bishop and Independence. All of these newspapers contain some coverage of the study area and its immediate vicinity. A number of newspapers were based in Pioche, most of them short-lived. The Pioche Daily Record, the Pioche Weekly Record, and the Lincoln County Record-the same publication with different names at different times-has been published almost continuously from 1870 to the present. This newspaper was searched for the years 1872-75, 1878-84, 1886-91, 1894-97, and $1900-05$, although there is undoubtedly relevant material throughout the balance of its lengthy period of publication. Belmont had short-lived newspapers during the years 1867-69. These papers were followed by the Belmont Courier which was published from 1874-1901. The Belmont Courier was sampled for the years 1888, 1890-91, 1897, and 1899. De Lamar, closer to the study area, had a newspaper published briefly in 1892-93 (the Ferguson Lode), which was followed by the De Lamar Lode from 1894-1906. These papers were not searched. Tybo, near Belmont, had a newspaper published from 1877-80, the Tybo Sun, which was not sampled. Independence, at about the same distance from the study area as Tybo, has had a newspaper from 1870 to the present (the Inyo Independent), as well as 
other shorter-lived newspapers. Bishop had a newspaper published in 1881-82 (the Bishop Creek Times) and from 1885 through the 1920s (the Inyo Register), as well as shorter-lived newspapers. None of these Owens Valley area newspapers were searched, although they contain coverage of events in and around the study area, as do newspapers in more distant locations in California (as indicated by articles cited in a number of books and articles dealing with the study area). Priority in the search effort was assigned to sources closer to the study area, so potentially valuable searches of many other sources have yet to be done. Citations in historical works like Lingenfelter (1986) and Zanjani (1988) guided the authors to specific articles in several newspapers that were not otherwise searched or sampled.

Beginning in 1901, newspapers began to be published in Tonopah, about the same distance from the study area as Pioche. Newspapers published in Tonopah included the Tonopah Bonanza, published from 1901-29; the Tonopah Daily Times, published from 1915-29; the Tonopah Miner, published from 1902-21; the Tonopah Mining Reporter, published from 1921-29; the Tonopah Sun, published from 1904-10; the Tonopah Times-Bonanza, published from 1929 to the present; and several other papers that were short-lived or that began publication in the 1960s. Newspapers searched for the 1901-05 period were the Tonopah Daily Sun, for 1905-06, and the Tonopah Miner, for 1903-05.

For the period 1905 to 1916, there were several newspapers published in the mining boomtowns of the Oasis Valley region just west of the study area. From 1905-09, there were several contemporaneous papers in this area. From 1910-12, there was only one, and from 1913-16 there was one. Because of their proximity to the study area, the limited number of years these newspapers were published, and the limited number of pages per issue, it was feasible to conduct a full search of all the Oasis Valley newspapers for this period. A full search was completed for all issues available on microfilm of the Beatty Bullfrog Miner, published from 1905-09; the Bullfrog Miner, published from 1905-09; the Gold Center News, published from 1906-07; the Pioneer Topics, published from 1904-09; the Rhyolite Daily Bulletin, published from 1907-09; the Rhyolite Herald, published from 1905-12; the Transvaal Miner, published briefly in 1906; and the Carrara Obelisk, published slightly later in 1913-16. In this same period, newspapers began to be published in Goldfield, including the Goldfield News, published from 1904-56; the Goldfield Review, published from 1908-09; the Goldfield Tribune, published from 1906-30; and a number of shorter-lived papers. The Goldfield News was searched for the years 1905-06. Newspapers began to be published in Las Vegas in this same period, beginning with the Las Vegas Times and the Las Vegas Age, both in 1905, with coverage encompassing the study area. Of the Tonopah newspapers for this period, only the Tonopah Sun was searched, for the year 1910. No search was performed in the Las Vegas, Pioche, Caliente, or Belmont papers for this period.

From 1916 through 1946, the newspapers published closest to the study area were those published in Goldfield, Tonopah, Pioche, Caliente, Las Vegas, and the Owens Valley. There was also coverage of events in the study area in newspapers published elsewhere in Nevada and in California. For this period, the Tonopah Mining Reporter was searched for the years 1922-26, the Tonopah Daily Times for the years 1928 and 1933, and the Caliente Herald for the years 1928-29. Sources like Lingenfelter (1984) and Zanjani (1988) were used to guide reviewers to a selected number of relevant articles for this period in a number of newspapers for which no further search was performed. 
From 1946 to 1956, the Goldfield News published a section titled "The Beatty Bulletin," which provided detailed coverage of the Oasis Valley, Amargosa, and Pahrump areas. A full search of "The Beatty Bulletin" and the Goldfield News was conducted for the years 194649, 1950, and 1953.

From the early 1960s through at least the 1970s, the newspaper published closest to the study area was the NTS News, published on the Nevada Test Side. In its coverage of Native American people, the NTS News provides information about the early twentieth century and about archaeological finds, but not about contemporary Native American people in the study area. Both the Nevada Historical Society and the Central Nevada Historical Society have incomplete holdings of the NTS News, of which all available issues were searched for the years 1964-69.

Data from newspapers has been cited as fully as possible, both in the text and in the bibliography. This has been done to assist readers in accessing the original sources.

Early twentieth century small town newspapers often printed out-of-sequence, erroneous volume numbers, issue numbers, and issue dates. Often pages were not numbered. Furthermore, in microfilm reprints it is often not clear what the original sequence of pages may have been if the pages are not numbered.

To provide as much assistance as possible for readers who may wish to examine any of the newspaper items cited in this report, newspaper citations in most cases contain all of the following: (1) both the date of publication and the volume and issue number, if the original contains both; (2) the page number (if pages were not numbered in the original, in most cases page numbers have been assigned, corresponding to the sequence of pages in the microfilm print); and (3) the column number. In many cases, the title or header of the article or item is also included in the citation.

The authors believe that the disadvantage of having lengthy citations in the text is outweighed by the advantage of providing several cross-referencing data points to readers who may wish to locate the original newspaper sources.

\section{Visits to Archives in Nevada}

The importance of visits to archives should be emphasized. Many sources not available to the authors in the collections of the University of Michigan library were obtained through interlibrary borrowing. Unfortunately, many valuable sources located in Nevada collections do not circulate. Many noncirculating materials of relevance to the study were not listed in any published work and not listed in interlibrary cataloging systems. The on-site searches at the Nevada Historical Society, the Central Nevada Historical Society, UNR Special Collections Department, UNR Oral History Program, and UNR Government Documents Department were essential for identifying and examining many relevant books, manuscripts, and photographs. The on-site archival visits were also very important for the newspaper search. In several days of on-site work at the University of Nevada-Reno, the authors searched through a number of newspapers they had not yet been able to obtain through interlibrary borrowing. They also performed much more extensive searches of other newspapers for which they had previously been able to examine only a few rolls of microfilm. 


\section{CHAPTER THREE}

\section{Native American Groups With Ties to the Study Area}

The issue of how many recent Native American occupants have left traditional cultural properties in the Yucca Mountain area can be partially determined with available data. The location and approximate number of these Native American people, as well as of those who traditionally occupied the Yucca Mountain study area, can be established with some certainty.

\section{Traditional Native American Groups (Pre-1850)}

The Westem Shoshone, Southern Paiute, and Owens Valley Paiute are the Native American ethnic groups having the most direct affiliation with traditional cultural resources located in the Yucca Mountain area. These groups are well-documented as having lived in the area for hundreds of years before the arrival of the first Euroamericans in the mid-1800s (Kuykendall et al., 1978).

\section{Traditional Holy Land}

The Yucca Mountain area is located on the northern boundary of the Mojave Desert and southern boundary of the Great Basin Desert, and is an important area to many Native American ethnic groups. These groups resided there for thousands of years, using the land and its resources and building these into a cultural definition of themselves as a people. Most of these groups perceive that they were created in these two deserts and that, in so doing, the Creator gave them a special supernatural responsibility to protect and manage the land and its resources. In western terminology, these deserts are their Holy Land (Spicer, 1957).

The Southern Paiutes, for example, believe that they were created by the supernatural near Charleston Peak-called Nuvagantu-located in the Spring Mountains, twenty-five miles southeast of the proposed Yucca Mountain high-level radioactive waste repository (Kroeber, 1970; Laird, 1976; Stoffle and Dobyns, 1983). According to Laird (1976:122):

In prehuman times Nuvagantu was the home of Wolf and his brother, Mythic Coyote. It was the very heart of Tuwiinyaruvipu, the Storied Land.

There was and is no place in Southem Paiute traditional territory more sacred than the Spring Mountains and the areas around them. Concerns for this sacred area have been expressed repeatedly in cultural resource studies involving Southern Paiute people (cf. Stoffle, Dobyns, and Evans, 1983). Most recently, Nevada Paiutes expressed concerns for Pahrump Valley as a sacred area (Stoffle, Evans, and Jensen, 1987) because of its relationship to the Spring Mountains.

\section{Overlapping and Shared Territory}

Traditional occupation and joint-use boundaries have changed over time, so that for the last thousand years, three or four Native American ethnic groups could have occupied any specific location in the Mojave Desert or Great Basin Desert, such as the Yucca Mountain area. Each of these ethnic groups could have traditional cultural values regarding any specific location, including the Yucca Mountain area. 
An extensive national debate over which Native American ethnic groups resided in what lands at the time of European intrusion was conducted during the federal Land Claims Commission hearings (Kuykendall et al., 1978). During these legal hearings, it was generally agreed that Yucca Mountain was located on the border between lands traditionally used by the Southem Paiutes and the Western Shoshones (see Map 3; Kelly, 1934). Accepted historical, archaeological, and ethnographic documents place the two ethnic groups in the Yucca Mountain area for hundreds of years before Euroamerican intrusion (Kroeber, 1970; Pippin and Zerga, 1983; Steward, 1938). There is little scientific argument as to which Native American ethnic groups have a primary traditional claim to the Yucca Mountain area.

\section{Ethnic versus Band Affillation}

It is essential to distinguish between the concept of an "ethnic group," such as the Westem Shoshone, Southern Paiute, or Owens Valley Paiute, and a "localized band," like the Yomba or Moapa. The difference between these two types of social groups has important implications for defining which Native American groups should be consulted regarding site characterization activities at the proposed Yucca Mountain high-level radioactive waste facility.

The last two hundred years of Southern Paiute ethnic group history can be used to illustrate the two concepts and to demonstrate their importance to the study. The Southern Paiutes are a people (an ethnic group) who share a common culture, language, and society. They traditionally occupied and used a wide territory ranging from Black Mesa, Arizona, in the east to Yucca Mountain, Nevada, in the west and from Sevier Lake, Utah, in the north to Palo Verde Valley on the lower Colorado River in the south (see Map 3; Kelly, 1934). Within this ethnic group territory there were a number of local subterritories that were the primary residence of local bands of Southern Paiutes (see Map 3; Stoffle, Jake, Bunte, and Evans, 1982). The broader ethnically-based social unit-termed here the "nation"-functioned to move goods and services back and forth between ecological zones, thus increasing the population carrying capacity of the region under ethnic control (Stoffle and Evans, 1976; Stoffle, Jake, Bunte, and Evans, 1982). Just as goods and services moved within Southem Paiute national territory, so did people. The same pattern of an ethnic nation with an extensive ethnic group territory subdivided into a number of local subterritories also characterized the Western Shoshone people and the Owens Valley Paiute people.

The effects of disease and territorial encroachment by Euroamericans combined to virtually eliminate the national functions and integration of the Southern Paiute nation by the $1840 \mathrm{~s}$ (Stoffle and Dobyns, 1982; Stoffle, Dobyns, and Evans, 1983). After this time, local bands increased in political importance; however, ethnic identity and the movement of people between ecological zones persisted. As agricultural lands along rivers and springs were appropriated by Euroamericans and as wild food species were reduced by the impact of Euroamerican livestock and by the cutting of pinyon and mesquite trees, wage employment became an increasingly important component of Paiute and Shoshone subsistence. Sometimes this meant relocating the primary residence to Euroamerican settlements or to their fringes (cf. Crum et al., 1976:99-89,91,101; Bowers and Muessig, 1982:22; Forbes, 1967:153; Rusco, 1975:128). In southern Nye County, Euroamerican settlements developed in the same oasis core areas where the bulk of the Native American population already 


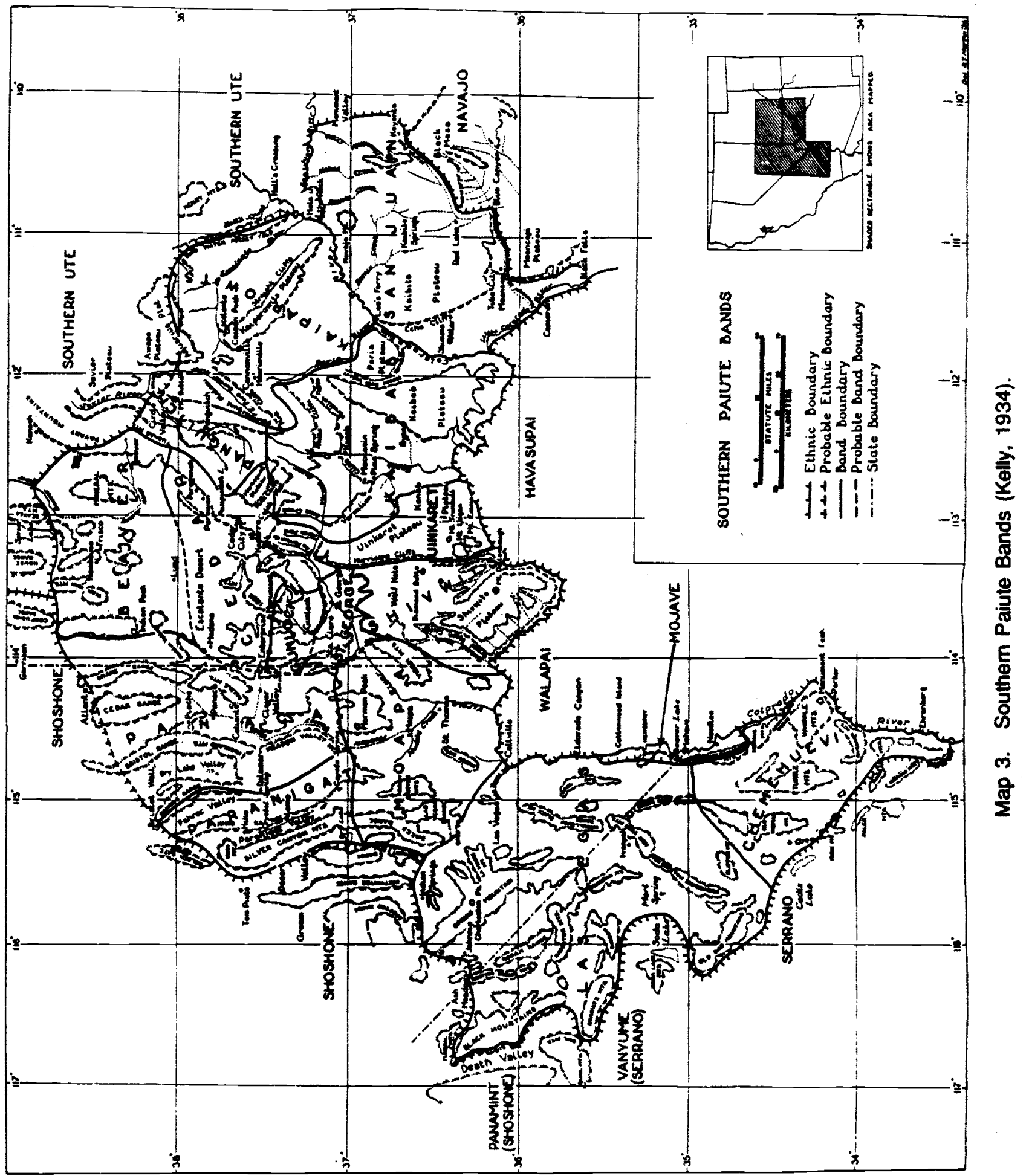


made its primary residence. Here, for much of the Native American population that had survived the impacts of epidemics, employment in the Euroamerican economic sector meant relatively little change in residence site. Some of the Native American families who had their primary residence at springs north and east of the study area probably did relocate into the core areas as Euroamerican impact upon the springs intensified. From these residential "labor camps," whether located at or near the site of traditional villages or in new locations adjoining the Euroamerican towns, Paiute and Shoshone people continued to retum to traditional locations to harvest wild food plants in areas that had not been too heavily impacted by Euroamerican development activities, including the Yucca Mountain area. For much of the twentieth century, Paiute and Shoshone peoples' livelihood derived both from employment in the Euroamerican economic sector and from traditional activities of farming and of harvesting nondomesticated flora and fauna.

In the nineteenth century, Euroamericans established state territorial boundaries and jurisdictions that divided Westem Shoshone lands between two states, Nevada and California, and divided Southern Paiute lands between four states, Nevada, Utah, Arizona, and California. These developments contributed to an undercutting of the national functions and integration of these ethnic groups. In the twentieth century, the federal government began to set aside portions of traditional territory as reservation lands for Western Shoshone, Southern Paiute, and Owens Valley Paiute people. In doing so, the federal government began to treat local labor camp populations as tribes and their leaders as chiefs. This political fiction recognized legitimate local leadership and control over local resources, but ignored the traditional cultural rights and obligations of the larger nations to use and manage the natural resources throughout their ethnic group territory. For each of these nations, their territory had been conceived as their Holy Land and their responsibilities toward the natural resources had been understood as responsibilities toward a Holy Land.

Despite the divisive effects of the federal political fiction of the localized tribe, Southern Paiute, Western Shoshone, and Owens Valley Paiute people continue to try to maintain national functions and ethnic group integration. Perhaps one of the more obvious mechanisms for this is the practice of placing children of the same couple on different tribal registration rolls. So if, for example, a man on the roll at the Las Vegas Paiute Indian Tribe marries a woman on the roll at the Moapa Paiute Tribe, they may register their children with either tribe. If one of the children marries a person from the Shiwwits Paiute Indian Tribe, their children could be registered at any one of three reservations.

For Western Shoshone people in Nevada, particularly elders, it is not uncommon for individuals to be registered at a location where they do not live nor have ever lived. The federal government told these people they had to register someplace, so they simply picked a location, often for unexplained reasons.

Owens Valley Paiute people also often live in a location different from where they are officially registered. This is usually due to different parents originating from different locations, similar to Southern Paiute people. And so Southern Paiute, Western Shoshone, and Owens Valley Paiute people continue to weave themselves back together through kinship ties in an effort to compensate for state and federal administrative decisions that force separation of the ethnic group. 
The most important implication of the distinction between traditional ethnic group concerns and the concerns of contemporary localized tribes is that all of the tribes that currently exist within the traditional ethnic territory must be consulted to permit a complete ethnic group response to a project occurring somewhere within the traditional territory. If county and state boundaries are utilized to define the limits of who should be consulted, only those tribes that happen to have a reservation located within those Euroamerican political units are consulted. In order not to exclude some or even most of the ethnic group's members, it is important to consult with any contemporary tribe that contains living members who are identified with a traditional ethnic group territory.

\section{Recent Native American Occupants (Post-1850)}

Euroamerican encroachment on Western Shoshone, Southern Paiute, and Owens Valley Paiute traditional territories began in the 1820s. In southern Nye County, many of the most valuable and productive natural resources were in the hands of Euroamericans by the 1870 s and 1880s. Western Shoshone, Southem Paiute, and Owens Valley Paiute people increasingly gravitated towards wage labor opportunities during the late 1800 s, as did other Native American people in Nevada.

Both the literature survey and field interviews have confirmed that Native American people lived and worked on many of the Euroamerican-owned farms and ranches in Oasis Valley, Ash Meadows, and Pahrump Valley. Some Native American people occupied their own farms and lived in their own villages near the Euroamerican farms where they were employed. In addition, most Euroamerican mining and railroad camps had an adjoining or nearby camp where Native American workers and their families lived. The literature survey documented such Native American settlements on the outskirts of Beatty, Rhyolite, and Bullfrog, as discussed in Chapter Four later.

Living on or near Euroamerican-owned ranches in Oasis Valley, Ash Meadows, and Pahrump Valley, and living in camps adjoining Beatty, Bullfrog, and Rhyolite, Native American people were in fact continuing to occupy the same core areas they had occupied traditionally, though many of the springs had been appropriated by Euroamericans. Native American people continued to make their primary residence in their traditional core areas, and they continued to travel outward from these core areas to harvest natural resources in seasonal use areas like Yucca Mountain. Western Shoshone, Southern Paiute, and Owens Valley Paiute people have continued to be knowledgeable about the Yucca Mountain study area over the years. In 1950, Dick Shutler was guided on an early archaeology survey of the Yucca Mountain area by a Shoshone man from Beatty (Pippin and Zerga, 1983:26). In recent interviews, the authors of this review were told many details of the area by Native American people who used to live and work in the study area before it was withdrawn from the public domain (Stoffle, Evans, and Harshbarger, 1988).

The Euroamerican economic sector of mining, railroad construction, and large-scale commercial agriculture attracted Native American people of many ethnic backgrounds. Railroad lines facilitated the movement of Native American people over great distances, and the use of railroads by Native American people in Nevada is well-documented (CIA, 1874c:281; "Indians Will Join in Celebration," Tonopah Daily Sun, July 3, 1906, inside p., col. 4). The literature survey documented that Native American people from southeastern tribes emigrated to Ash Meadows and Pahrump Valley around the turn of the century (1900 Nevada census 
rolls; Correspondence Files for 1917, Lorenzo D. Creel Collection, UNR). Native American laborers often were recruited by Euroamerican companies for construction labor or other jobs. In southern Nevada, there were numerous ephemeral peaks of mining activities. After an initial find of high grade ore in a location, a large mining camp would often grow up almost ovemight, drawing prospectors from all over the continent as well as laborers from waning camps elsewhere in the region. If the ore proved disappointing, a mining camp might depopulate as quickly as it had grown. In southern Nye County, there were numerous ephemeral boomtowns and camps, including several in the study area. Transvaal and Wahmonie are two of several mining districts within the boundaries of the Nevada Test Site and Nellis Air Force Range (Pippin and Zerga, 1983:55,62-63). Native American people from ethnic groups other than Paiute and Shoshone may have been among the influx of laborers at these camps.

Native American people who immigrated to the traditional lands of the Westem Shoshone and Southern Paiute in southern Nevada to work for Euroamerican commercial operations or to farm on their own behalf may have begun to use and perceive the new land and its resources as they had their own traditional territories. For example, Drover (1985) points out that Navajo workers who came to build a railroad across the Mojave Desert remained as maintenance crew members and lived in isolated communities along the railroad. Drover points out that these Navajo people created sweat-lodges, hogans, and other dwellings near the railroad that have cultural value to the Navajos as historic and religious structures. In another recent study (Stoffle, Evans, and Jensen, 1987:14-15), it was noted that Navajo women who were relocated to the Colorado River Indian Tribes reservation replaced most of their weaving and medicine plants with ones available in the Mojave Desert. Also important for the immigrants was leaming where minerals for pigment and medicine were located. Inevitably these people died and were buried in the new lands. In general, these data suggest that immigrant Native American people do develop culturally important attachments in traditionally consistent manners to cultural resources in new lands. The data further suggest that the longer the immigrant Native American people remain in the new lands, the more cultural attachments they will form to those lands.

\section{Involved Native American Groups Based on Literature Search}

The authors believe that the assessment of tribes in the area made in the initial stages of research remains accurate. The literature search did not document the residence of specific ethnic groups of Native American people other than Southern Paiutes and Western Shoshones in the study area. The literature review did document that a Cherokee man farmed at Ash Meadows from the early 1900s through at least 1920. The literature review also documented that among the early emigrants to Ash Meadows was a family with three children of mixed Euroamerican and Native American ancestry whose mother was identified as an Indian from North Carolina (1900 Nevada census rolls; Letter to L. D. Creel from William Morris, 1917, Lorenzo D. Creel Collection, UNR).

In addition to the presence of Westem Shoshones and Southem Paiutes in the study area, the literature search also documented (1) the entry into the region of Native American people from outside Nevada for trading purposes in the late 1800 s (Pioche Weekly Record, vol. 27 , no. 4 , October 6,1883 ) and (2) the presence of Native American people from unidentified ethnic groups in Idaho as part of a public dance performance in the Beatty area in 1908 (Bullfrog Miner, vol. IV, no. 12, June 20, 1908). The literature search did not locate documentation for the presence of Native Americans other than Southem Paiutes, Westem 
Shoshones, and Owens Valley Paiutes as laborers during the construction and operation of the railroads adjacent to the study area, although this may have occurred given the numbers of unskilled laborers employed (Rhyolite Herald, vol. II, no. 34, December 21, 1906), the shortage of local labor (Bullfrog Miner, vol. II, no. 9, May 28, 1906), advertisements for Native American laborers for railroad construction work published in the community of Searchlight just across the border in California (Searchlight, vol. 2, no. 4, July 3, 1903, p. 6, col. 2), and the documentation of Navajo people's roles in railroad construction in the larger region in the early 1900s (Drover, 1985).

\section{Contemporary Involved Native American Groups}

The literature search supports the assumption (that guided the Native American study design) that the Western Shoshone, Southem Paiute, and Owens Valley Paiute ethnic group members are the most directly involved with the cultural resources of the Yucca Mountain study area-particularly members of the Western Shoshone and Southern Paiute ethnic groups. The literature search further supports the assumption that most of the involved people are enrolled at one of fourteen reservations listed in Table 1; are in contact with the Las Vegas Indian Center, Nevada; or are members of the nonward Pahnump Paiute Indian Tribe. All of these groups have been consulted and literature has been searched regarding the ethnohistory of all three of these ethnic groups.

There are a number of Native American people (estimated at more than 5,000 ) who do not belong to the Western Shoshone, Southern Paiute, or Owens Valley Paiute ethnic groups and who are living in southeastem Nevada. These people are living far from their traditional lands and reservations in towns (especially Las Vegas) located within a couple of hours drive from Yucca Mountain. Most of the Native American people who live off-reservation in southeastern Nevada are not enrolled at one of the local reservations. For example, the State of Nevada Employment Security Department estimates that there were 5,640 Native American people living in Clark County in 1985, of which only $298(5.3 \%)$ were enrolled at the Las Vegas Paiute or Moapa Paiute Indian reservations. Similarly, the Employment Security Department estimates that there were 120 Native American people living in Lincoln County, where there are no reservations. These off-reservation Native American people have been involved in the study through the Las Vegas Indian Center, which has served as the official point of contact.

Table 1 is a listing of the location and approximate number of involved Native American peoples. The population figures in Table 1 reflect the best population information available. The numbers of Native American people living at any one place is a reasonable estimate based on previous field work and available published reports. The exact numbers of people enrolled with each tribe changes because of deaths and births. Different sources of information were used when the authors perceived that a more recent source provided a more accurate population figure (see Table Notes). While the actual population figures will vary slightly, the relative percentage of the Native American people living and/or enrolled at one location is not expected to be significantly different from that presented in Table 1. 
Table 1. Number and Location of Indian People Involved in the Yucca Mountain Cultural Resources Study

I. Southern Paiute Tribes ${ }^{a}$

Chemehuevi Paiute Tribe, California

Chemehuevi Paiutes, Colorado River Indian Tribes, Arizona

300

Las Vegas Paiute Tribe, Nevada

300

Moapa Paiute Tribe, Nevada

113

Paiute Indian Tribe, Utah

185

Kaibab Paiute Tribe, Arizona

516

$\underline{200}$

Subtotal

II. Owens Valley Paiute Tribes

Lone Pine, Califomia

Fort Independence, California

Big Pine, California

50

Bishop, California

500

Benton, California

$\underline{050}$

Subtotal

III. Western Shoshone Tribes ${ }^{c}$

Timbisha, California $\quad 199$

Yomba, Nevada $\quad 60$

Duckwater, Nevada $\quad \underline{106}$

Subtotal

IV. Ott-Reservation American Indian Peoples

Pahrump Valley, Nevada

Las Vegas, Nevada

Subtotal

Total Involved Indian Peoples

a Since 1977, Richard Stoffle has been in regular contact with these tribal groups and has conducted numerous surveys which have required a listing of tribal members from the tribal rolls. These figures reflect his most current knowledge about these groups.

b These figures are derived from a book by the U.S. Department of Commerce Federal and State Indian Reservations and Indian Trust Areas.

c The Timbisha Shoshone figure comes from their Federal Acknowledgment documents; none of these Indian people are members of any other Indian tribe (Federal Register, vol. 47 , no. 214 , November 4,1982 ). Only about 50 of these Indian people live at Furnace Creek, California, but as soon as this new tribe receives full government services and land, many of the tribal members are expected to return to the Death Valley area. The last two figures are derived from the 1980 U.S. Census and were checked with a member of one of these two tribal governments. 
- The Pahrump Paiute population figure comes from the personal knowledge of Richard Arnold, Director of the Las Vegas Indian Center. An unknown (but perhaps significant) number of Native American people reside on farms and ranches in Nye and Lincoln Counties. The Las Vegas population is an estimate based on the State of Nevada Employment Security Department report for 1985. The figure was derived by taking the 5,640 Clark County Indian population estimate and subtracting the 113 people enrolled at the Las Vegas Paiute reservation and the 185 people enrolled at the Moapa Paiute reservation. These figures were checked by the Director of the Las Vegas Indian Center, who works on a daily basis with Indian people not enrolled at a southeastern Nevada reservation. They live either in the City of Las Vegas or in the rural areas of Clark, Lincoln, and Nye Counties. 


\title{
CHAPTER FOUR
}

\section{Summary of Native American Occupancy and Use}

\author{
Introduction
}

This chapter presents summary chronologies for the Nevada Test Site and for adjacent areas whose Native American residents used the Nevada Test Site area: Chapter Five presents a detailed chronological data base in which each item is flagged by keywords identifying places, activities, and ethnic grouping if known. Chapter Four summarizes and analyzes the data presented in greater detail in Chapter Five.

This chapter is divided into three main sections, followed by a conclusion. The first section provides a conceptual discussion of three different categories of use area: core areas, permanently occupied springs, and temporary or seasonal use areas. The second section discusses the major factors and vectors of change that have affected Native American occupancy and use of the study area and vicinity since contact, including epidemic disease, interethnic violence, appropriation of resources by Euroamericans, new pattems of employment and trade, and cultural change. The third section presents a place-by-place chronological summary of Native American occupation and use for the following areas: (1) Oasis Valley, a core area; (2) Ash Meadows, a core area; (3) Pahrump Valley, a core area; (4) permanently occupied springs in the vicinity of Yucca Mountain; and (5) Yucca Mountain and Fortymile Canyon, a seasonal and temporary use area.

Tables $2 a$ and $2 b$ provide a simplified summary overview of the data on Native American use and occupancy.

\section{Native American Use Areas}

\section{Core Areas}

The term "core area" is used to refer to places where large numbers of Indian people kept permanent residences and from which they went out to manage, harvest, and hunt other resources. Oasis Valley, located near Beatty, Nevada, west of the Nevada Test Site, Ash Meadows to the south of the Nevada Test Site, and Pahrump Valley to the southeast have all been core areas of Native American occupation both prior to and since Euroamerican contact in what is today southern Nye County. Each of these core areas contains numerous large springs supplying abundant water. In each core area the abundant water supported several Native American villages located within easy walking distance of each other. There was aboriginal agriculture of com, squash, and beans in the Ash Meadows and Pahrump Valley core areas (Steward, 1941:231-232; Steward, 1938:183) and there may have been aboriginal agriculture in the Oasis Valley core area as well. The core areas were continuously inhabited, though the roster of individuals and families present in the core areas varied over time.

For their residents, these oasis core areas served as the primary residence within a much larger territory that included other places inhabited seasonally and areas used seasonally for harvesting plant, animal, and mineral resources. From the core areas, people traveled to seasonal camps at higher elevations and in more arid locations to harvest pinyon nuts, wild 
Table 2a. Documented Native American Occupancy or Use, by Place and Decade Through the 1940s: Tabular Summary of Data Presented in Chapters Three and Four

\begin{tabular}{|c|c|c|c|c|c|c|}
\hline Decade & $\begin{array}{l}\text { Oasis } \\
\text { Valley }\end{array}$ & $\begin{array}{c}\text { Amargosa } \\
\text { Valley }\end{array}$ & $\begin{array}{c}\text { Ash } \\
\text { Meadows }\end{array}$ & $\begin{array}{l}\text { Pahrump } \\
\text { Valley }\end{array}$ & $\begin{array}{l}\text { Spring } \\
\text { Mountains }\end{array}$ & $\begin{array}{l}\text { Springs: } \\
\text { Captain Jack } \\
\text { Whiterock } \\
\text { Oak } \\
\text { Tippipahb }\end{array}$ \\
\hline \multicolumn{7}{|l|}{$1820 \mathrm{~s}$} \\
\hline \multicolumn{2}{|l|}{$1830 \mathrm{~s}$} & & $\mathbf{R}$ & & & \\
\hline \multicolumn{2}{|l|}{$1840 s$} & & $x$ & $x$ & & $x$ \\
\hline \multicolumn{2}{|l|}{$1850 \mathrm{~s}$} & & & $\mathbf{R}$ & & \\
\hline \multicolumn{2}{|l|}{$1860 s$} & & $x$ & $\mathbf{R}$ & $\mathbf{R}$ & $\mathbf{R}$ \\
\hline $1870 \mathrm{~s}$ & $\mathbf{R}$ & $\mathbf{R}$ & $\mathbf{R}$ & $\mathbf{R}$ & $\mathbf{R}$ & \\
\hline 1880s & $\mathbf{R}$ & & $\mathbf{R}$ & $\mathbf{R}$ & $\mathbf{R}$ & \\
\hline $1890 \mathrm{~s}$ & $\mathbf{R}$ & & $\mathbf{R}$ & $\mathbf{R}$ & & \\
\hline $1900 \mathrm{~s}$ & $\mathbf{R}$ & & $\mathbf{R}$ & $\mathbf{R}$ & & \\
\hline $1910 \mathrm{~s}$ & $\mathbf{R}$ & & $\mathbf{R}$ & $\mathbf{R}$ & & $x$ \\
\hline $1920 \mathrm{~s}$ & $\mathbf{R}$ & & $\mathbf{R}$ & $\mathbf{R}$ & & $\mathbf{R}$ \\
\hline $1930 \mathrm{~s}$ & $\mathbf{R}$ & & $\mathbf{R}$ & $\mathbf{R}$ & & \\
\hline $1940 \mathrm{~s}$ & $\mathbf{R}$ & & & $\mathbf{R}$ & & \\
\hline \multicolumn{7}{|c|}{$\begin{array}{l}\text { The symbol " } \mathrm{R} \text { " has been used to indicate that residence of Native American people is } \\
\text { documented for an area in a particular decade. The symbol " } \mathrm{x} \text { " indicates that presence o } \\
\text { use by Native Americans is documented. Lack of documentation of Native American resi- } \\
\text { dence or use in the Euroamerican sources examined does not, of course, mean that } \\
\text { Native American people did not reside in areas and periods of times that lack } \\
\text { documentation. }\end{array}$} \\
\hline \multicolumn{7}{|c|}{$\begin{array}{l}\text { Captain Jack Spring, Whiterock Spring, Oak Spring, and Tippipah Spring have been } \\
\text { grouped together because of their proximity to one another. }\end{array}$} \\
\hline
\end{tabular}


Table 2b. Documented Native American Occupancy or Use, by Place and Decade Through the 1940s: Tabular Summary of Data Presented in Chapters Three and Four

\begin{tabular}{|c|c|c|c|c|c|}
\hline Decade & $\begin{array}{l}\text { Cane } \\
\text { Spring }\end{array}$ & $\begin{array}{l}\text { Yucca } \\
\text { Mountain }\end{array}$ & $\begin{array}{c}\text { Fortymile } \\
\text { Canyon }\end{array}$ & $\begin{array}{c}\text { Tempiute } \\
\text { area }\end{array}$ & Pahranagat \\
\hline \multicolumn{6}{|l|}{$1820 \mathrm{~s}$} \\
\hline \multicolumn{6}{|l|}{$1830 \mathrm{~s}$} \\
\hline $1840 \mathrm{~s}$ & $R$ & & & & $x$ \\
\hline \multicolumn{6}{|l|}{$1850 \mathrm{~s}$} \\
\hline $1860 \mathrm{~s}$ & & & & $x$ & $R$ \\
\hline $1870 \mathrm{~s}$ & & & $\mathrm{R}$ & & $R$ \\
\hline $1880 \mathrm{~s}$ & & & & $x$ & $R$ \\
\hline \multicolumn{6}{|l|}{$1890 \mathrm{~s}$} \\
\hline \multicolumn{6}{|l|}{$1900 \mathrm{~s}$} \\
\hline $1910 \mathrm{~s}$ & & & & $x$ & \\
\hline \multicolumn{6}{|l|}{$1920 \mathrm{~s}$} \\
\hline \multicolumn{6}{|l|}{$1930 \mathrm{~s}$} \\
\hline $1940 \mathrm{~s}$ & & & & & \\
\hline
\end{tabular}

a The symbol " $R$ " has been used to indicate that residence of Native American people is documented for an area in a particular decade. The symbol " $x$ " indicates that presence or use by Native Americans is documented. Lack of documentation of Native American residence or use in the Euroamerican sources examined does not, of course, mean that Native American people did not reside in areas and periods of times that lack documentation. 
grains, medicinal plants, rabbits, sheep, deer, and other plant, animal, and mineral resources. It was also necessary to travel through the territory at various times during the year to assess the development of crops to be harvested later, so as to plan the timing and location of harvesting efforts. Individuals and families who made their permanent residence in one of these core oasis areas also left the core area to visit relatives living in other core areas or at permanently occupied springs and to participate in social events including seasonal festivals, funeral ceremonies, and less formal social gatherings. Individuals and families also might shift their residence from one core area to another for a variety of reasons, including marriage and obligations to or disagreements with relatives.

Extending beyond the core area of primary residence, the territories used by families and bands were very extensive. For example, an individual or family whose primary residence was in Oasis Valley might visit the Death Valley area, Yucca Mountain, the southern end of the Belted Range, Shoshone Mountain, Ash Meadows, and various points in between over the course of a year or several years to carry out a variety of activities. Which parts of the territory a family visited in a particular year would vary with climatic factors that had affected the growth of flora and fauna. Where families traveled also would be influenced by the scheduling and location of social events in the region in that particular year.

After contact, Euroamericans took control of most of the springs in these core areas. In Oasis Valley and Ash Meadows, Native American people retained control over a few of the springs and engaged in independent farming and ranching well into the twentieth century.

\section{Permanently Occupled Springs}

To the east and north of Yucca Mountain are several springs that were used by Native American people from pre-contact times to the 1950s. Some of these springs were occupied year-round, others seasonally, and still others on a regular but intermittent basis. These springs include Tippipah Spring and Toboban Spring on the slopes of Shoshone Mountain; Cane Spring on the slope of Skull Mountain; the Ammonia Tanks, Captain Jack Spring, Whiterock Spring, and Oak Spring around the southern end of the Belted Range; and numerous other smaller springs and water catchments.

Some families apparently made their primary residence at one of these springs. Other families apparently resided at one of these springs only during the winter season. Still other families came to the area and used the springs only during the fall season to conduct rabbit drives on the flats, harvest pinyon nuts in the mountains, and harvest wild grains at a variety of locations. A fall festival held in the Ammonia Tanks area in some years drew people to the area from Oasis Valley and elsewhere.

Aboriginal agriculture of corn and squash was documented for Cane Spring by the Jayhawker emigrants in 1849 , and was probably practiced at other springs in the vicinity as well. Although Native American people used and inhabited these spring sites, the springs in the area north and east of the cultural resources study area do not constitute a core area like Ash Meadows or Oasis Valley. The springs north and east of Yucca Mountain are not concentrated together in a single basin and do not provide a concentrated water resource sufficient to support several Native American villages in close proximity. Because the water sources and Native American habitation sites were more spread out in this area, the impact of Euroamerican appropriation of water resources was even heavier here than in the core areas, where there were sufficient springs to support Euroamerican settlements and enable 
Native American people to retain the use of at least a few springs. Some of the springs in this area were appropriated for the use of stage relay stations during the last three decades of the nineteenth century. After this period, it is possible the springs may have reverted to use by Native American people for a time. Scattered and often ephemeral Euroamerican ranching, prospecting, and mining activities that made use of springs in the area apparently coexisted with continued Native American use of at least some of these springs until the creation of the Nevada Test Site.

\section{Areas of Seasonal or Temporary Use}

Areas at high elevations and areas with limited water sources including small springs, seeps, and tinajas (rock catchments) were used seasonally. Such areas were used seasonally by Native American people who made their primary residence in a nearby core area or at one of the permanently occupied springs like those to the east of Fortymile Canyon. From the core areas and permanently occupied springs, people traveled to seasonal camps at higher elevations and in locations with limited water sources for the purpose of harvesting pinyon nuts, wild grains, rabbits, sheep, deer, and other plant, animal, and mineral resources. It was also necessary to travel through these seasonal use areas at various times during the year to assess the status of crops or game species that would be harvested later and plan the timing and location of hunting and harvesting efforts. Yucca Mountain is a seasonal and temporary use area, used for harvesting wild grains and medicinal plants; hunting deer, sheep, and other game; and hunting or capturing wild horses.

\section{Territories Encompassing All Three KInds of Use Areas}

The territory used by any particular band, family, or individual would encompass both a primary residence in a core area or at a permanently occupied spring and a very extensive area in which a variety of seasonal activities were performed. Territories of different families and of different bands would often overlap and interpenetrate in areas used seasonally, and people would often reciprocally share the use of their territories with other families and other bands.

\section{Major Factors and Vectors Affecting Native American Occupancy and Use Since Contact}

\section{Disease}

Throughout the Americas, and throughout the Great Basin and Mohave deserts, Native American populations were drastically reduced by the introduction of diseases carried by Euroamericans, diseases to which Native American people had no prior exposure or acquired immunity. The impact of disease upon Native American population levels is welldocumented for areas of Nevada that had newspapers by the mid-nineteenth century. Native American people in southem Nye County were exposed to the same disease vectors, but there were few Euroamericans settled in the region prior to the twentieth century and there were no newspapers in the area until the early 1900s. By the time events in southern Nye County began to be chronicled in detail by Euroamerican sources, the Native American population had already been severely reduced. What appeared to be the baseline Native American population to early settlers in Oasis Valley and Ash Meadows was undoubtedly a much smaller population than had occupied the area before contact. And the decline continued during the first decades of Euroamerican settlement in the region. Harsha White, who 
moved to Pahrump Valley in the late 1870 s and took the census for that region in 1900 , observed that the local Native American population had declined dramatically during the period of his residence. He attributed the decline to the impacts of liquor, changes in diet, and venereal diseases from contacts with Euroamericans (Beatty Bullfrog Miner, vol. I, no. 27 , September 23, 1905, p. 1, col. 1). There is considerable data on succeeding waves of epidemics and their fatal impact upon Native American people for the Pioche area, where publication of a newspaper began in 1870. Until 1904, Pioche was the location nearest to the study area with a newspaper. It can be assumed that the waves of epidemics reported in the area around Pioche (some fifty miles from the study area) also impacted Native American people in the study area, Oasis Valley, Ash Meadows, and Pahrump. Native American people throughout southern Nevada traveled widely, facilitating the spread of disease from one location to another. Even in areas without permanent Euroamerican settlement, there was frequent contact between local Native American people and Euroamerican prospectors and travelers, with water sources often serving as loci for the communication of disease.

\section{Violence}

Violent conflicts between Native Americans and Euroamericans were another important demographic factor contributing to a reduction of the Native American population in and around the study area. Euroamericans began killing Native American people as soon as contact began and this pattern continued well into the twentieth century. In Nevada, as elsewhere, the number of Native American people killed by Euroamericans was far greater than the number of Euroamericans killed by Native American people, as noted by a Euroamerican in the Pioche area in 1873 (Pioche Daily Record, vol. 6, no. 13, April 1, 1873, p. 3, col. 3). Shootings of Native Americans by other Native Americans in southern Nye County were also all too frequent following the acquisition of alcohol and guns in combination with the economic, social, and cultural stresses upon Native American populations engulfed by the Euroamerican frontier.

Violence perpetrated upon Native American people by Euroamericans fesulted in efforts by Native American people to avoid contact with Euroamericans in the early post-contact period. Accounts by the forty-niner emigrants of their travels through the Nevada Test Site area document this pattern of withdrawal from contact. The same accounts record that the forty-niners took Native American people as captives in the Nevada Test Site area. The travelers saw numerous indications of Native American habitations and presence, and on several occasions saw Native American people fleeing from their approach.

\section{Appropriation of Resources}

In a desert region like southern Nevada, water is the crucial resource. Well before there was any permanent Euroamerican settlement in the vicinity of the study area, Euroamerican livestock were heavily impacting resources important to Native American people in the study area and vicinity. From the 1830 s on, large numbers of livestock were moved through southern Nevada along the Old Spanish Trail, consuming wild grasses Native American people harvested for seed grains and impacting springs in the vicinity of the trail. Livestock of the emigrants who crossed the Nevada Test Site area in 1849 undoubtedly had a heavy impact on springs and associated plant resources along the routes. Mormon and other mining and livestock grazing activities in the region intensified in the 1850s. In the study area and vicinity, Native American resistance to Euroamerican presence and Euroamerican appropriation 
of resources often focused on livestock, with Native Americans shooting oxen, horses, and cattle. In 1849, several forty-niner oxen that had grazed at the Native American farm at Cane Spring for ten days were shot two days after the party of forty-niners had resumed its joumey (Johnson and Johnson, 1987:61; Belden, 1954:64). At Ash Meadows, Native Americans specifically targeted the work horses in the herd of livestock brought to the area by the Younts in 1876, killing all the horses with collar marks, in an apparent attempt to prevent Euroamericans from establishing a ranch there (Doherty, 1974:166-167).

Beginning in the 1870 s, Euroamericans began establishing permanent ranches in the vicinity of the study area and appropriated many of the springs in the Oasis Valley, Ash Meadows, and Pahrump core areas, as well as some of the springs in the area east of the cultural resources study area. Native American people, however, retained control over some of the spring water resources in each of the three core areas.

Euroamerican appropriation of water resources accelerated after 1904 with the mining boom that centered in the Oasis Valley area. This boom soon led to the construction of a railroad through the region. Many of the Oasis Valley springs were acquired by corporations that supplied piped water to the Oasis Valley boomtowns and to the ore processing mills servicing the mines of the region. Even in the boom years, however, Native American people continued to retain the use of some of the springs in the Oasis Valley area and in Ash Meadows.

It is important to note that Native Americans and Euroamericans perceived transactions concerning water differently. In the Euroamerican understanding, when Euroamericans traded money or other goods to Native Americans for the use of a spring, the Euroamericans believed that they had acquired outright ownership of the spring and that the Native American people had relinquished any prior rights. In their understanding of the same transaction, Native American people believed that they had accepted gifts or payments in return for sharing the use of water sources over which they, the Native Americans, retained jurisdiction. It was, of course, the Euroamerican legal system and Euroamerican interpretations of these transactions that prevailed. In 1918, Ash Meadows Charley gave evidence of just such a clash of viewpoints. He testified that he had accepted payment from a Euroamerican in exchange for permitting the Euroamerican to use some of the water from a spring for one year only. The Euroamerican challenged Ash Meadows Charley's rights to any further use of the spring water on the basis of the payment the Euroamerican had made to him ("Testimony Taken in Ash Meadows," September 29, 1917, Correspondence Files of Lorenzo D. Creel). At springs where they saw no permanent habitation, Euroamericans believed no one owned the spring and that it was their right to claim the spring, even though Native American people may have had traditional rights to the spring and may have used it on a regular basis. A case in point are the "wild grapes" which Euroamericans observed at many of the springs throughout the region. What looked like wild grapes to Euroamericans was probably a significant, regularly harvested crop for Native American people in the core areas.

Euroamerican settlement in the Oasis Valley, Ash Meadows, and Pahrump Valley core areas began in the late $1800 \mathrm{~s}$. In the early $1900 \mathrm{~s}$, a mining boom in the vicinity of Oasis Valley resulted in a massive influx of Euroamerican population, the establishment of numerous towns and mining camps in and around Oasis Valley, and the construction of a railroad across the northern edge of Ash Meadows and through Oasis Valley. As these develop- 
ments occurred, Native American people took up a variety of new employments, in addition to continuing their traditional pursuits of cultivating corn, beans, squash, and other crops; harvesting pinyon nuts, wild grains, and other plants; hunting game; hunting and capturing wild horses; harvesting firewood; and harvesting selected mineral resources.

Many of the jobs local Native American people took in the Euroamerican economic sector were similar to, or extensions of, their traditional employments. Many local Native Americans worked as farm and ranch laborers for Euroamerican employers. Some continued to farm independently, marketing crops to the new mining towns, including traditional crops like melons. Local Native American men worked as prospectors, guides, cowboys, trackers, and deputies, all of these being jobs to which Native Americans brought a superior knowledge of terrain, water sources, game species, and mineral resources, acquired through generations of intimate familiarity with the extensive territories used by local Native American families. Local Native American men worked as wood cutters, construction laborers, teamsters, and mine laborers. Local Native American women worked as domestics, cooks, and laundresses, again extensions of traditional domestic tasks. Some local Native American women wove baskets for commercial sale. Native American people harvested and marketed pinyon nuts and firewood in the new mining towns, traditional activities that now had an expanded market during the boom years of the mining camps and towns. It should be noted that most of these occupations were temporary, seasonal, or intermittent, enabling Native American people to maintain their traditional transhumant adaptive pattern of seasonally leaving the core areas to inspect the progress of plant and animal crops to be harvested later; to harvest pinyon nuts, seed grains, medicinal plants, and game; and to participate in fall festivals and other social events.

Native American people played a major role in the development of mining in southern Nye County. Many local Native Americans were active prospectors on their own behalf, locating their own mining claims. Many of the producing mines in southem Nye County were initially located by local Native American people. Several Native American people guided Euroamerican prospectors to valuable ore deposits, but were not made equal partners as they may have expected and may have been promised. Mineral prospecting was one of the activities that took Native American people into the cultural resources study area. Native Americans also worked as mine labórers.

\section{Cultural Change}

Native American people in the study area and its environs early adopted many aspects of Euroamerican culture. They adopted Euroamerican clothing styles and new modes of transportation including the wagon, the railroad, and later the automobile. They leamed sufficient English to function in the Euroamerican economic sector. Native American people adopted new cultural elements from Euroamerican culture, while retaining most of their traditional Native American culture. Alongside employment in the Euroamerican economic sector, they continued to practice their traditional pattern of seasonal harvesting of wild food resources. They continued to use extensive territories and to define their territories in the same way as they had for generations. Traditional medical practices and the use of traditional medicinal plants continued. Native American people continued to speak their traditional language. The 1900 census indicates that in many of the Native American families in southern Nye County, wives and children did not speak English, while most male heads of household are listed as speaking English. 
Native American people achieved a new synthesis of traditional Native American culture and Euroamerican culture, functioning in two overlapping cultural worlds. Intermarriages between local Native American women and Euroamerican men and the resulting "mixed blood" descendants were important loci for this synthesis.

Once Native American people had adopted industrially produced clothing and other industrially produced goods, the archaeological remains of a remote Native American habitation site became difficult to differentiate from the archaeological remains of, for example, a prospector's camp. It is sometimes assumed that because a site (or strata of a site) contains industrially produced goods, this indicates it was occupied by Euroamericans, overlooking the fact that Native Americans acquired and used most of the same goods during a period that is now over a century in duration. Artifacts at Whiterock Spring illustrate this issue. The artifacts include the remains of a 1928 Buick, from which Worman concluded that ranching was probably carried on there into the 1930s (Worman, 1969:36). In recent field interviews, a Shoshone man who had lived at Whiterock Spring pointed out the remains of the old Buick and stated that it had been abandoned there by another Shoshone man now living at Duckwater. Both men had resided at Whiterock Spring in the 1920 s and 1930 s.

From the mid-1800s on, Native American people in the study area and vicinity selectively adopted much of Euroamerican culture, while retaining most of their traditional culture, creating a new synthesis. The Ghost Dance movement in the period $1889-90$ was a dramatic instance of this synthesis. The Ghost Dance movement was a synthesis of traditional elements of Native American culture and elements of Christianity. Frequent Ghost Dances are documented for the area around Pioche in those years. It is likely that some Native American people in the Oasis Valley, Ash Meadows, and Pahrump core areas and in the arc of permanently occupied springs to the east and north of Yucca Mountain participated in the Ghost Dance movement. However, unlike the Pioche area, none of these areas had a newspaper to chronicle local events during that period.

Native American people were also impacted by some of the addictions purveyed by Euroamerican culture. Michael Hittman documents widespread use of opium by Paiute people in Smith and Mason Valleys in the nineteenth century, as a response to the demographic, economic, and cultural stresses resulting from the impact of the Euroamerican frontier upon Native American communities (Hittman, 1973). This pattern may or may not have occurred in the study area as well. Certainly alcohol had a major impact on Native American society in the area. Alcohol consumption is implicated in many deaths of local Native American people - deaths resulting from quarrels between Native Americans and Euroamericans, as well as from quarrels between Native Americans.

\section{Place-by-Place Chronologies}

\section{Oasis Valley Core Area}

Oasis Valley was a core area of Native American occupancy in pre-contact times, and Native American people have continued to occupy the area up to the present. Oasis Valley has numerous large springs and an intermittent watercourse, the Amargosa River.

The literature review documents the continuing residence of Native American people in Oasis Valley from the 1870s, when the first Euroamericans settled there, through the 1960 s 
(see Table 2). Field interviews document that Native American people have continued to reside in Oasis Valley to the present. When Euroamerican settlement in Oasis Valley began, there were several Native American villages located at major springs along the valley. Several of these locations continued to be the site of Native American communities well into the twentieth century. Other Native American settlements grew up on the outskirts of the mining boomtowns located in the Oasis Valley area in the decade beginning in 1904.

Oasis Valley was a core area of primary residence within a much more extensive territory of seasonal use areas. The territory used by Native American people residing in Oasis Valley encompassed Yucca Mountain, Shoshone Mountain, Yucca Flats, the Belted Range, and the Grapevine Mountains (Steward, 1938:36,93,96). They traveled even further to visit relatives and participate in social events in the Kawich Mountains and in the Pahrump area (Steward, 1938:96,185). The territory used by Oasis Valley Native American people thus encompassed the cultural resources study area. As of the late 1800s, Oasis Valley area Native Americans had a long-established pattern of uses on Yucca Mountain and uses in the area north and east of Yucca Mountain. Many of these uses continued until the creation of the Nevada Test Site. Oasis Valley area Native American people periodically journeyed through the study area to join people living at the springs around the southern end of the Belted Range for fall rabbit drives, harvesting of grains and pinyon nuts, and a five-day fall festival. People from Ash Meadows also participated in the fall festivals held in the area at the south end of the Belted Mountains and sometimes harvested as far north as Shoshone Mountain, just east of Yucca Mountain (Steward, 1938:90,183-185).

The Native American population of Oasis Valley was undoubtedly drastically reduced by disease in the nineteenth century. Much of this reduction occurred prior to Euroamerican settlement in the area and well before newspapers began to provide detailed chronicles of events in the area. By the time Euroamerican documentation of the area began, much of the demographic impact of disease upon the Native American population had already occurred. After several decades of population decline, the Native American population seems to have reached a reduced plateau by the late 1800 s. Since the late $1800 \mathrm{~s}$, the Native American population in the Oasis Valley area seems to have remained fairly constant or declined only slowly through at least the 1940s. This was in contrast to enormous fluctuations in Euroamerican population levels during the same period. There was only a handful of Euroamerican settlers living in Oasis Valley until 1904, when a mining boom struck the area. Within a few years, the town of Rhyolite had attained a population of several thousand (Weight and Weight, 1985:18,26). There were many other smaller towns and mining camps including Bullfrog, Beatty, Springdale, Pioneer, Gold Center, Transvaal, and others, all in Oasis Valley or in the surrounding mountains within a few miles of Oasis Valley. By 1909, the boom had passed and the Euroamerican population was in decline. By the time of the 1910 census, the population of Rhyolite had already declined to 630 persons identified as Whites and 10 persons identified as Indians (1910 Nevada census rolis). Rhyolite and most of the other settlements were soon transformed into ghost towns. The peak of population reached in Oasis Valley sometime during the first decade of this century has never been equaled since then. The 1920,1930,1940, and 1950 censuses show a population of only a few hundred people in all of southern Nye County. In 1960 and 1970, the population of the Oasis Valley area (censused as Beatty township) had barely surpassed 1,000. In 1980 the population of Beatty township was about 3,500 , still considerably less than the population of Rhyolite at its peak.

At least since the late 1800 s, there apparently have been both Shoshone and Paiute families and intermarriages involving Paiutes and Shoshones living in the Oasis Valley area. 
1870-1900 Perlod Powell and Ingall's survey of Numic peoples in 1871 apparently missed the Oasis Valley area, giving population figures and other data for Pahrump, Ash Meadows, and the Amargosa south of Ash Meadows, but not for the Oasis Valley area. Julian Steward's Shoshone interviewee with the initials "TSt," of Beatty, stated that there were half a dozen Native American villages in the Oasis Valley in the vicinity of Beatty in about 187580. According to "TSt," there were villages at (1) Indian Camp at the head of Oasis Valley; (2) Howell Ranch near Springdale; (3) Hu:nusu, probably the location of Goss Springs; and (4) Hick's Hot Springs, as well as several smaller camps at the mouth of Beatty Wash (Steward, 1938:94).

Montillus Murray Beatty, one of the earliest Euroamerican settlers in Oasis Valley, married a local Native American woman after he arrived in about 1894. Reportedly the local Native American community offered him hospitality for a time, then asked him to leave. When he did not, the intercession of the Native American woman he later married was apparently crucial to sparing his life and permitting him to remain in the area (Earl, 1986:10-13). M.M. Beatty's son Montillus Murray Beatty, Jr., identified his mother as a local Paiute (M.M. Beatty, Jr., Taped Interview, 1968). Intermarriages between local Native American women and some of the earliest Euroamerican settlers in the Oasis Valley and Ash Meadows enabled these ethnic groups to coexist. Similarly, intermarriages of Paiutes and Shoshones in the same region presumably facilitated coexistence between Paiutes and Shoshones in those areas where their territories met and overlapped.

1900-09 Period This is the period with the fullest documentation, because during this period there were several mining boomtowns in the Oasis Valley area. Newspapers were published in three of these towns, including a newspaper published daily in Rhyolite in 1907-09.

M.M. Beatty, Jr., stated that during his childhood (late 1890s and early 1900s) several bands of Native Americans camped at his father's ranch near the later site of Beatty, with several different bands of 15 to 20 persons each spending some of their time there and spending other parts of the year as far away as Furnace Creek and Pahrump (M.M. Beatty, Jr., Taped Interview, 1968). M.M. Beatty, Jr., also stated that young Native Americans whose families were staying in the area often accompanied M.M. Beatty, Sr., into the mountains to the east to capture and tame wild horses (M.M. Beatty, Jr., Taped Interview, 1968).

Until 1906, a band of about 25 Native American people, which had a man named Panamint Joe Stuart ${ }^{1}$ as its headman, lived at a ranch at the spring where the town of Springdale was later established. Euroamerican sources typically refer to Panamint Joe as a Shoshone Chief. In 1906, Panamint Joe Stuart sold the ranch to A.J. Lidwell and relocated his band to a wood camp in the Grapevine Mountains (Bulfrog Miner, vol. II, no. 23, August 31, 1906, p. 1, col. 2; Bullfrog Miner, vol. II, no. 24, September 7, 1906, p. 3, col. 6; Rhyolite Herald Pictorial Edition, Midwinter Supplement, March 1909). Testimony from a 1906 court case documents that there was a Native American-owned and operated ranch near Howell's ranch (Beatty Bullfrog Miner, vol. 1, no. 42, January 6, 1906, pp. 3-4).

1 Some sources use the spelling "Stuart," while others use the spelling "Stewart," when referring to Panamint Joe Stuart or other relatives. For consistency, this report uses the spelling "Stuart" when referring to Panamint Joe Stuart. 
There was another Native American settlement at the northem edge of Rhyolite. In 1908, a fight between two Native American men at the Native American camp north of Rhyolite resulted in a death (Rhyolite Daily Bulletin, vol. 1, no. 233, October 13, 1908, p. 1, col. 1). Later that year, at Christmas, the sheriff jailed the entire camp of Native Americans residing at the northern edge of Rhyolite after Euroamerican neighbors complained about a great deal of drinking and quarreling in the Native American sector (Rhyolite Daily Bulletin, vol. 1, no. 294, December 26, 1908, p. 4, col. 1). Photographs also document the presence of Native American people in Rhyolite. Postcards from Rhyolite's boom days provide photographs of nine Native American people seated in front of a building in Rhyolite ("Some of Rhyolite's First Inhabitants," A.E. Holt album, Nevada Historical Society), a Native American encampment near Rhyolite ("Indians Gambling- A Bunch of Piutes in Camp at Rhyolite, Nevada," Indian Photograph \#549, Ethnic File, Nevada Historical Society), and a "squaw race" in Rhyolite (Indian Photograph \#544, Ethnic File, Nevada Historical Society). There is also a group photograph of Panamint Joe Stuart, his son Young Joe, and a Euroamerican named Pete Busch, all in Rhyolite (Ritter, 1982:no page number). Another photograph shows an Indian camp near Bullfrog, a few miles from Rhyolite (inscribed "Our Neighbors at Bullfrog Nevada," Indian Photograph \#550, Ethnic File, Nevada Historical Society).

Native American people also lived in and near the town of Beatty. A Native American woman identified as the wife of Captain Jack died of pneumonia in Beatty in 1906 (Beatty Bullfrog Miner, vol. II, no. 37, December 1, 1906, p. 12, col. 2). In 1907, two Native American women engaged in a violent quarrel in the street in Beatty and several other Native Americans were onlookers, as well as a crowd of Euroamericans (Beatty Bulfrog Miner, vol. 3, no. 40, December 28, 1907, p. 1, col. 2). Photographs show an apparent family grouping ("Indians in Beatty," Indian Photograph \#553, Ethnic File, Nevada Historical Society) and three Native American women standing next to a small building ("Indians near Beatty," Indian Photograph \#555, Ethnic File, Nevada Historical Society). When M.M. Beatty became postmaster of Beatty in 1905, a Tonopah newspaper noted and described him as "very popular with whites and reds alike" (Tonopah Miner, vol. IV, no. 5, July 15, 1905, p. 6, col. 4).

Native American people from Oasis Valley and the surrounding region participated in Fourth of July celebrations and other public sporting events and entertainments in Rhyolite and Beatty. Fourth of July celebrations in the Oasis Valley towns during the mining boom sometimes included special racing events limited to Native American participants. Native American women participated in a "squaw race" as part of the Fourth of July program in Rhyolite in 1908 (Bulltrog Miner, vol. IV, no. 16, July 11, 1908, p. 5, col. 3). A photograph exists of one such "squaw race" in Rhyolite ("Squaw Race, Rhyolite Nevada," Indian Photograph \#544, Ethnic File, Nevada Historical Society). Native American people also participated in races not limited to Native American participants. In 1907, the winner of a Fourth of July horse race in Beatty was a horse owned by a Euroamerican and ridden by a Native American girl (Beatty Bulfrog Miner, vol. 3, no. 15, July 6, 1907, p. 1, col. 2). In 1908, Panamint Joe ran in a Fourth of July 70-yard dash for men over 50 in Rhyolite (Bullfrog Miner, vol. IV, no. 16, July 11,1908 , p. 5, col. 3).

Native American people gave several public performances of Native American dances in the Oasis Valley towns. In 1908, Panamint Joe orchestrated several such performances in Rhyolite and Bulfrog, including one on the Fourth of July. On at least one of these occasions, a troupe of Native American dancers from Idaho was scheduled to perform (Rhyolite 
Daily Bulletin, vol. 1, no. 178, April 20, 1908, p. 1, col. 3; Bullfrog Miner, vol. IV, no. 5, April 25, 1908, p. 8, col. 3; Rhyolite Herald, vol. IV, no. 8, June 17, 1908, p. 5, col. 5; Rhyolite Herald, vol. IV, no. 10, July 1, 1908, p. 10, col. 4; Rhyolite Daily Bulletin, vol. 1, no. 228 , October 7, 1908, p. 4, col. 1).

Native American people in the Oasis Valley area worked as prospectors, guides, trackers, and cowboys in the surrounding region, and marketed pinyon nuts and firewood harvested in the surrounding mountains. A 1906 court case documents that Bob Montgomery met "Indian Johnny" in Oasis Valley and hired him to work as a prospector, staking claims for Montgomery in the surrounding region (Beatty Bullfrog Miner, vol. 1, no. 42, January 6, 1906, pp. 3-4). In 1906, Panamint Joe marketed pinyon nuts in Rhyolite (Bulffrog Miner, vol. II, no. 24, September 7, 1906, p. 3, col. 6). in 1908, three Native American men-Panamint Joe Stuart, Wild Bill, and Amargosa Albert-accompanied a mining engineer and another Euroamerican to survey mining claims owned by the Native American men in the Panamint Range. Later Panamint Joe was back in Beatty showing samples of ore from his mining claims (Beatty Bullfrog Miner, vol. IV, no. 13, June 20, 1908, p. 4, col. 2; Bullfrog Miner, vol. IV, no. 12, June 13, 1908, p. 5, col. 3). In 1909, Panamint Joe lost his life, apparently from food poisoning, while he and his wife Maggie guided a party of Euroamericans through the Death Valley region (Rhyolite Herald, vol. V, no. 13, July 24, 1909, inside p., col. 4). Bob Montgomery helped provide financial support for Panamint Joe's widow as a reward for the Stuart S' services to Euroamericans, sending money to her in Beatty (Rhyolite Herald, vol. V, no. 13 , July 24, 1909, inside p., col. 4; Rhyolite Herald, vol. V, no. 21, September 18, 1909, p. 2, col. 3).

1910-19 Perlod The 1910 census enumerated 30 Native American people in Springdale precinct, north of Beatty. Their occupations included three cowboys, two prospectors, two farm laborers, and one laundress. All were listed as paying taxes. All were identified as Shoshones (1910 Nevada census rolls).

The 1910 census enumerated ten Native American people in Rhyolite precinct. Their occupations included two basket weavers and two woodcutters. All were identified as Shoshones (1910 Nevada census rolls).

In 1915, the Carrara newspaper published several editorials complaining about illegal sales of liquor to Native American people in the surrounding area and calling for stricter law enforcement measures toward both Euroamerican and Native American parties involved in such sales (Carrara Obelisk, vol. II, no. 24, April 17, 1915, p. 8, col. 2; Carrara Obelisk, vol. III, no. 4, November 27,1915, p. 8 , col. 1). Carrara, today a ghost town, was located a few miles south of Beatty.

1920-29 Period Beatty's Fourth of July program for 1923 included a race "solely for the Indian maids on their ponies" (Tonopah Mining Reporter, vol. 1, no. 44, July 1, 1923, p. 2, col. 7). In 1924, Mike Hughes, a Native American man living in Beatty, shot his next-door neighbor, Ika Shaw, who was also a Native American. The two men were brothers-in-law. Mike Hughes served prison time for the non-fatal shooting (Tonopah Mining Reporter, vol. III, no. 37, May 10, 1924, p. 4, col. 6; State of Nevada vs. Mike Hughes, 1924). Native American people from Beatty were among those employed in the construction of Scotty's Castle during the period 1925-31 (Sennett-Walker, 1987:83). 
1930-39 Perlod A joint report by the Bureau of Indian Affairs (BIA) and the Soil Conservation Service states that in 1937 there were about fifteen Native American families living in Beatty and another four families living at a ranch two miles northwest of Beatty. The report indicated that many of the families used the camp at Beatty as a winter camp, while others made it their residence year-round (TC-BIA, 1937b:4,7). Another BIA joint report includes the names of eight Native American men from Beatty who were employed by the Works Progress Administration (WPA) during 1936: Holley W. Charley, Wilbur Patterson, John Scott, Louie Sharp, Ike Shaw, Sullivan Shaw, Tom Stewart, and Jud Stewart (TC-BIA, 1937a:21). The BIA survey noted that during the 1930 s many of the Beatty area Native American people had been employed in the construction of Death Valley Scotty's Castle, and that local ranch jobs formerly filled by Native Americans had been filled by importing labor from elsewhere. With the construction work at an end, Beatty area Native Americans no longer had access to ranch jobs and had also lost their former "squatters' rights" to the use of land on ranches where they had formerly been employed (TC-BIA, 1937b:2,4). As of the late 1930s, WPA employment was the most important source of income.

An oral history by Ert Moore, who taught at Beatty School from 1936 to 1942, provides additional information about the Beatty Native American community in the late 1930s. Moore stated that there was a Shoshone Indian camp located across the Amargosa River from the town of Beatty (Moore, 1979:20-21). Harvesting wild food resources was still a major part of subsistence for Oasis Valley Native American people. In the fall of 1936, the entire Native American camp at Beatty was empty and none of the Native American students were in school, having gone north to harvest pinyon nuts (Moore, 1979:25). Living in the Native American community at Beatty was a medicine man who, according to the schoolteacher, had considerable influence among the local Native American community (Moore, 1979:25).

In the 1930s, Native American students formed a substantial fraction of the student body of Beatty School. A photograph of the Beatty junior high school class in the 1932-33 school year shows a total of eleven students, at least three of Native American ancestry (Photograph, File 309, Palsgrove Collection, Central Nevada Historical Society). In 1936, Beatty School had a total enrollment of about $\mathbf{5 0}$ students, the majority of them Native Americans. In a high school class of ten students, eight were Native Americans. In the lower grades, there were about 25 Native Americans and 15 Euroamericans (Moore, 1979:20-21). Even for the most advanced Native American students, English was still a second language (Moore, 1979:20-21). A photograph of the entire Beatty School student body for the school year 1938-39 shows 49 students, 19 of them with visible Native American ancestry (Collection of Chloe Calvin Lisle).

In the late 1930s, two Beatty Shoshone men, Ike Shaw and Tom Steward, were among those Native American people in the Beatty area interviewed by Percy Train and others in a study of medicinal plants used by Nevada Indian people (Train et al., 1974:1,4). Train stated that lke Shaw of Beatty "had a wide knowledge of medicinal plants and a substantial record of effective cures" (Train et al., 1974:4). Julian Steward also carried out ethnographic interviews with Native American people in Beatty in 1935 (Stewart, 1938:preface, no page numbers).

Court documents also substantiate the continued residence of Native American people in Oasis Valley in the 1930s. In 1932, Mike Hughes, a Native American resident of Beatty, was accused of assisting Fred $\mathrm{E}$. Lea in illegally branding cattle belonging to Samuel S. Lockett 
in the Black Mountain area. Two other Native Americans were hired as trackers in an attempt to locate the horses and the places at which the accused men had camped (State of Nevada vs. Fred E. Lea and Mike Hughes, 1932; and State of Nevada vs. Frederick E. Lea, 1933).

1940-49 Period In 1947, players on the Beatty softball team included several men of Native American ancestry: two members of the Cottonwood family and two members of the Strozzi family (Goldfield News and Beatty Bulletin, vol. 44, no. 12, August 1, 1947, p. 1, col. 7; Goldfield News and Beatty Bulletin, vol. 44, no. 15, September 5, 1947, p. 1, col. 4). In 1949, Danny Shoshone, a Native American youth from Beatty, was jailed for robbery and later escaped (Goldfield News and Beatty Bulletin, vol. 47, no. 1, May 13, 1949, p. 1, col. 1). Players in a Labor Day horseshoe pitching contest with teams from Beatty, Shoshone, and Tonopah included several Native American men from Beatty: Bombo Cottonwood, Spike Cottonwood, Bobby Shoshone, and Joe Strozzi (Goldfield News and Beatty Bulletin, vol. 47, no. 18 , September 9,1949 , p. 1 , col. 6).

1950-61 Perlod In 1950, Bessie Shaw died in Beatty. She was known as a medicine woman, the wife of Ike Shaw, and had lived in Beatty for many years (Goldfield News and Beatty Bulletin, vol. 48, no. 31, November 3, 1950, p. 1, col. 4). In 1953, David Shoshone of Beatty was injured while riding in a truck with a Euroamerican family (Goldfield News and Beatty Bulletin, vol. 50, no. 39, June 26, 1953, p. 1, col. 2). In 1953, Gilbert Landis, a Paiute man who grew up in the Lida area, became the deputy sheriff for Beatty. In 1957, he was promoted from part-time to full-time status and served until 1968, when he retired (Tonopah Times Bonanza and Goldfield News, July 5, 1968, p. 4, col. 1). In 1959, Joseph Strozzi, a local man whose mother was a local Native American, became another sheriff's deputy for the Beatty area (Oath of Office, 1959). In 1961, David Shoshone was killed in an automobile accident. His belongings were taken to the Cottonwood family (Inquest File, 1961).

Perlod Since 1961 Field interviews have documented the continued residence of Native American people in Oasis Valley through the 1960s, 1970s, and 1980s to the present. An expanded literature search for this period would be expected to locate published documentation as well.

\section{Ash Meadows Core Area}

Ash Meadows has been a core area of Native American occupancy in both pre-contact and post-contact times. Native American people continued to reside in Ash Meadows at least through the 1950s. Ash Meadows has numerous large springs and was an area where aboriginal irrigation agriculture of corn, beans, squash, and sunflowers was practiced by Paiutes (Steward, 1941:231-232). The literature review located documents substantiating continuing residence of Native American people in Ash Meadows from contact through the 1930s, and field interviews documented continued residence of Native Americans through the 1950s. The data indicate that, at least in the twentieth century, there were both Paiute and Shoshone families living in the Ash Meadows core area.

Ash Meadows is directly south of Yucca Mountain, with no intervening mountains, and it is likely that Native American people from the Ash Meadows area entered the Yucca Mountain area frequently. Indeed, it is probable that many historical references to the Ash Meadows region encompass the southern portion of the Yucca Mountain area. According to Steward's Native American interviewees in Ash Meadows, Native Americans from Ash Meadows some- 
times journeyed to Shoshone Mountain, east of Yucca Mountain, to harvest pinyon nuts. Sometimes they harvested sand bunch grass seeds (Oryzopsis hymenoides) at Big Dune, just south of Yucca Mountain. They also occasionally hunted deer at Shoshone Mountain, butchering them there and drying the meat and skins before transporting them home (Steward, 1938:183). Ash Meadows people also traveled north, presumably through the cultural resources study area, to participate in fall festivals held in some years in the area around the Ammonia Tanks (Steward, 1938:90,98).

1840-80 Period Ash Meadows Native Americans attacked a party of emigrants who had crossed the study area in 1849, according to Ash Meadows Charley, an Ash Meadows Native American leader who was apparently a child in 1849 (Zanjani, 1988:62). Reportedly, Charles Breyfogle stayed in a Native American camp in Ash Meadows in 1864 and was trailed by an Ash Meadows Native American youth when he left there (Beatty Bulfrog Miner, vol. 1, no. 15, July 1, 1905, p. 5, col. 1). Powell and Ingalls' field survey of Numic people in 1871 listed a population of 31 Native Americans for Ash Meadows, identifying them as the "Kay-yai-chits tribe" led by Chief Nu-a'-rung (Powell and Ingalls, 1976:12). In 1876, a party of Euroamerican travelers led by Joseph Yount pastured a large herd of livestock in the mountains at the eastern edge of Ash Meadows. All the work horses were selectively killed by Native American arrows near "Horsehutem Springs." Reportedly the key party responsible for the killings was a Native American man thereafter known as "Hos Killim" (Brookes, 1970:10-11,39). When Euroamericans began settling in Ash Meadows in the late 1870s, many of the Ash Meadows Native Americans moved to a single large ranch of their own at a spring a mile east of Longstreet Spring (Lingenfelter, 1986:21).

1880-1900 Perlod In 1880, a Euroamerican man named Rockwell stole a mule from Shoshone people at a Shoshone settlement in Ash Meadows. After the Native Americans countered by confiscating his possessions and sending him away, Rockwell returned to the settlement at night and killed four Native American people (Lingenfelter, 1986:141). In 1891, there were three ranches in Ash Meadows. One of the three ranches was owned and operated by a Native American man named "Indian Charley" (Belmont Courier, vol. 18, no. 19, June 13, 1891, p. 2, col. 3). An 1892 article in the American Anthropologist indicates that the Native American population in Ash Meadows was a mixture of Paiute and Shoshone people (Coville, 1892:359). Mary Scott, an Ash Meadows Shoshone woman, found gold during a hunting trip east of Death Valley, and traded information on the location to Bob Black, an Ash Meadows Paiute man (Zanjani, 1988:114-115). According to Zanjani, there were two Native American camps near Longstreet's ranch during the 1890 s, one on a hillside behind Longstreet's cabin and another at Point of Rocks (Zanjani, 1988:76). One of the Native American families living in Ash Meadows at that time was the Black family, which was Paiute. One of the Black family members, Fannie Black, later married Jack Longstreet. This was one of many intermarriages in the region between Native American women and Euroamerican men, intermarriages that apparently enabled the different ethnic groups to $c \infty$ exist in the area.

1900-09 Period In the early 1900s, Native American men from Ash Meadows worked as laborers mining borax in the Ash Meadows area (Sennett-Walker, 1987:83). Ash Meadows Charley, a Shoshone resident of Ash Meadows, owned and operated a 200-acre ranch there. Mary Scott, also a Shoshone resident of Ash Meadows, owned and operated a 160acre ranch that produced vegetables, hay, and livestock (Beatty Bulffrog Miner, vol. 1, no. 
44, February 3, 1906, p. 3, col. 4). Among the Native American people identified in the 1900 census for the Pahrump precinct-encompassing all of southern Nye County -is the family of "Chartey Ash Meadow" (1900 Nevada census rolls).

Information about several murders also provides documentation about Native American people in Ash Meadows during this period. In 1905, Bob Black, an Ash Meadows Paiute man, killed his wife, his brother, and two other persons, all four of them Native American residents of Ash Meadows. Several Native Americans from the Ash Meadows area went to the authorities to give information on the whereabouts of the killer (Goldfield Review, vol. I, no. 38, July 13, 1905, p. 6, col. 2; Lingenfelter, 1986:314). Zanjani notes that Native American people usually preferred to handle crimes between Native American people themselves, but that in this case they were willing to cooperate with Euroamerican authorities because Bob Black had killed so many people (Zanjani, 1988:113-119). Bob Black was never tried or sentenced, however.

1910-19 Period The 1910 census enumerated 54 Native American people in the Johnnie precinct. The Johnnie precinct encompassed Ash Meadows and Pahrump Valley and the census data do not indicate which families lived in which area within the census precinct. For the Ash Meadows Charley family, it is clear that Ash Meadows was home, as it probably was also for the Ash family and the Meadows family. All the Native American people whose occupations are listed are identified as either farmers or farm laborers. Seven of the twenty Native American families listed in the census are identified as owning a farm. Thirtysix individuals are listed as having a Paiute mother and a Paiute father. Eight are identified as having both a Shoshone father and a Shoshone mother. Six are identified as having a Paiute father and a Shoshone mother (these are all children of Ash Meadows Charley). One is identified as having both a Panamint Shoshone father and a Panamint Shoshone mother. One is identified as having a white father and a Shoshone mother. Two are identified as having a white father and a Paiute mother (1910 Nevada census rolls).

In 1910, a Rhyolite newspaper reported that Indian farmers at Ash Meadows were shipping "dandy" melons to market in Rhyolite (Rhyolite Herald, vol. 6, no. 17, August 20, 1910, p. 1, col. 6).

Disputes over water rights in this period also provide documentation for the continued residence of Native American people in Ash Meadows and their continuing use of Ash Meadows springs to irrigate their own fields. In 1917, State Engineer J.G. Scrugham took testimony from Ash Meadows Charley regarding Charley's rights to spring water for irrigation. Ash Meadows Charley had accepted payment ten years earlier from a Euroamerican man, G.G. Davis, for the use of spring water for one year, and Davis was now challenging Ash Meadows Charley's rights to continue using the spring (Testimony Taken in Ash Meadows, September 29, 1917, Correspondence of Lorenzo Creel, UNR). William Gideon Morris, a Cherokee Indian who settled in Ash Meadows around 1907, filed claims and sought the assistance of Indian Agent Lorenzo D. Creel to perfect his title to water there (Letter to L. D. Creel from William G. Morris, December 28, 1917, Correspondence of Lorenzo Creel, UNR). Correspondence from 1918 by Indian Agent Lorenzo Creel indicates that "a number" of Native American people were residing and farming in Ash Meadows (Letter to Marguerite David from L. A. Dorrington and L. D. Creel, Lorenzo D. Creel Collection, UNR). 
1920-29 Perlod In 1920, William Gideon Morris, a Cherokee man self-employed as a farmer in Ash Meadows, wrote to Indian Agent L.A. Dorrington concerning three orphaned Paiute children under the guardianship of Mary Scott and Shoofly Jim, Shoshone residents of Ash Meadows. Morris stated that the children's deceased grandfather had left the children a home with three small springs, which the grandfather had used for irrigation since 1904. Morris also expressed concern about a syphilitic white man infecting the Native American community in Ash Meadows with venereal disease (Letter to L.A. Dorrington from William Morris, November 9, 1920; Letter to William Morris from L.A. Dorrington, November 24, 1920, Lorenzo D. Creel Collection, UNR). In the late 1920s, Native Americans from Ash Meadows were among those who were employed as laborers in the construction of Scotty's Castle during the period 1925-31 (Sennett-Walker, 1987:83). The 1928 obituary of Jack Longstreet stated that his Native American wife, Fannie Black, still had relatives living in Ash Meadows (Tonopah Mining Reporter, vol. 6, no. 46, July 28, 1928). After Longstreet's death, Fannie Black left the Kawich Range, where the Longstreets had been living, to stay with Native American relatives in Ash Meadows. However, she apparently found the pressure of her relatives upon her inheritance too much to bear and eventually left Ash Meadows (Zanjani, 1988:146-147).

1930-39 Perlod A BIA report indicates that, as of 1937, there were four Native American families living in Ash Meadows at an isolated location. Two of the families, comprising eight individuals, were studied. Population data for the other two families are not included in the report. The report stated that the community was headed by an elderly Native American woman who claimed ownership of the land. The report indicated that the land was apparently in the public domain and the woman's ownership uncertain, but that a recent controversy over water rights at that location had been decided in favor of the Native American people (TC-BIA, 1937b:10). About an acre was under cultivation as garden and orchard and another ten acres were irrigated as pasture. The report indicates that the cash income of this community was "supplemented rather substantially by the food, fruits, and vegetables the families raised" (TC-BIA, 1937b:10). The report noted that the bulk of the families' cash income was from wages in the private sector, working on ranches, and working for nearby mining companies (TC-BIA, 1937b:11,12).

Julian Steward conducted ethnographic interviews with three Native American residents of Ash Meadows: "AH" [apparently Albert Howell] identified as a "half-Negro, half-Southern Paiute man;" "MHo," identified as a "full-blood Southern Paiute woman" married to AH (the couple moved from Pahrump to Ash Meadows at the time of their marriage); and "MS," identified as "three quarters Southern Paiute, one-quarter Shoshoni," born about 1865 in Ash Meadows and still living there in the 1930s (Steward, 1941:212-214).

Period Since 1940 The literature review did not uncover documents concerning Native American occupancy in the more recent period, but field interviews have documented the continuing residence of Native Americans in Ash Meadows through the 1950s. Detailed census rolls for 1940 are sealed until 2012. More extensive sampling of the hundreds of microfilm rolls of Nevada and California newspapers with potential coverage of the Ash Meadows area would be expected to uncover documentation of Native American occupancy in Ash Meadows for the period since 1940 . 


\section{Pahrump Valley Core Area}

Pahrump Valley was a core area of Native American occupancy in pre-contact times, and Native American people have continued to occupy the area up to the present. Pahrump Valley has numerous springs and was an area where aboriginal cultivation of com, beans, squash, and sunflowers was practiced by local Paiute people (Steward, 1938:183). Pahrump Valley is southwest of Ash Meadows. The two areas are linked by numerous passes through low hills.

There is little physical separation between Ash Meadows and Pahrump Valley and there has been continuing close interaction between Native American people in Ash Meadows and in Pahrump Valley. Likewise, there has been continuing interaction between people in the Pahrump/Ash Meadows area with people in Oasis Valley and people in the area of permanently occupied springs north and east of Yucca Mountain. Thus, the study area is surrounded by core areas on the west and south and an arc of permanently occupied springs to the north and east. People in these surrounding areas of permanent occupancy maintained ongoing ties. They often participated in each others' festivals, intermarried, and sometimes shared the use of harvesting areas. In traveling between these zones of permanent occupation, undoubtedly Native American people frequently traveled through the study area.

Evidence for the close linkage between Pahrump and Ash Meadows, and thus for the linkage between Pahrump and Oasis Valley and the southern Belted Range, includes the following information. Julian Steward's Native American interviewees in the 1920s and 1930s stated that, in the nineteenth century and into the early twentieth century, the location of major festivals in the area rotated between Pahrump Valley, Las Vegas, and Moapa, with Native American people also coming from Ash Meadows, Oasis Valley, and San Bernardino to participate (Steward, 1938:184). Steward interviewee "AH" stated that Tecopa was chief of both Pahrump and Ash Meadows (Steward, 1938:185). In the 1900 census, Native American people in Ash Meadows and Pahrump (and in Oasis Valley as well) were enumerated together in a single census precinct called the Pahrump precinct. In the 1910 census, Native American people in Ash Meadows and Pahrump were enumerated together in a single census precinct called the Johnnie precinct, named after the mining district and mining camp that was located at the juncture of Ash Meadows and Pahrump Valley. In 1907, a Native American man, apparently a son of Ash Meadows Charley, was killed at the Pahrump ranch (Rhyolite Daily Bulletin, vol. 1, no. 4, September 26, 1907, p. 1, col. 2; Lingenfelter, 1986:21). In 1947, Bessie Shaw, an Oasis Valley Shoshone and a medicine woman, was in Pahrump for the funeral ceremonies honoring an Indian girl killed a year earlier (Goldfield News and Beatty Bulletin, vol. 44, no. 15, August 22, 1947, p. 1, col. 4).

1860-1900 Perlod In the 1860s, a Paiute man, Mormon Charlie, started the first stock ranch in Pahrump Valley (Lingenfelter, 1986:97). The 1869 expedition led by George M. Wheeler reported that a substantial number of Paiute people lived at Pahrump Spring and cultivated corn, squash, and melons there (Wheeler, 1872:84). The report also noted quantities of grapes growing at the spring. Wheeler referred to them as "wild grapes," but they were probably tended and harvested by the local Native American people. The report of the Wheeler expedition states that Paiute camps were found at several locations in the Spring Mountains, to the east of Pahrump Valley (Wheeler, 1875:37). Wheeler estimated a population of three or four hundred Native American people in the area from Las Vegas westward, encompassing the Spring Mountains and adjacent lowlands, with the greatest concentration 
in the Spring Mountains (Wheeler, 1875:21). It is not entirely clear how much territory is encompassed in Wheeler's estimate. It probably includes Pahrump Valley and may include Ash Meadows and the study area, as well as Spring Mountain. In any case, it indicates a substantial Native American population in the vicinity of the study area. A second expedition led by Wheeler in 1871 employed a number of Native American people from the Spring Mountain region: "From among the Pah-Utes, in the Spring Mountain Range, often as many as seven or eight guides and messengers were employed at one timen (Wheeler, 1871:28). In the report of their field studies in 1871, Powell and Ingalls listed a population of 56 Native American people at Pahrump Spring, identitying them as the "Par-room'-pats tribe under the leadership of Chief Ho-wi'-a-gunt" (Powell and Ingalls, 1873:11). By the mid-1870s, a number of local Paiute people were employed on a ranch in Pahrump Valley owned by a Euroamerican, Mr. Bennett (Doherty, nd:1-4). A traveler through the region in the late $1880 \mathrm{~s}$ noted that there were only a few Euroamericans living in Pahrump Valley and that most of the local population was Native American (Spears, 1892:86-87).

During this period, Native American people of Pahrump Valley were involved in the development of mining in the mountains around the valley. In 1878, Chief Tecopa of Pahrump showed Euroamerican settlers in Pahrump Valley locations of ore in the Spring Mountains, and mines were developed there by Euroamerican investors, including the Younts and the Whites of Pahrump Valley (Doherty, nd:5-6). In 1891, several Native American men were involved in a mining dispute at the Johnnie mine in Pahrump Valley. The dispute led to a shoot-out in which several Native American men were wounded and Phil Foote, a Euroamerican man, was killed (Lewis, 1969:5).

1900-09 Perlod The 1900 census for the Pahrump precinct enumerated a total population of 107 persons. Seventy-four were identified as full-blood Native Americans and three were identified as mixed-bloods with a Native American mother from North Carolina (1900 Nevada census rolls). Pahrump was the only census precinct in all of southern Nye County. Thus, the totals for both Native Americans and Euroamericans include Ash Meadows and Oasis Valley, as well as Pahrump Valley. In 1905, some 100 Paiute people participated in a ceremony at Pahrump to honor Chief Tecopa who had died a year before. Ponies were killed and clothing was burned in the traditional manner of honoring the dead ("Indian Powwow," Beatty Bullfrog Miner, vol. I, no. 27, September 23, 1905, p. 1, col. 1). In 1907, a Native American man, apparently a member of the Ash Meadows Charley family, was killed by a Euroamerican man named Charles Clay at Pahrump ranch, where a number of Native Americans were employed. Clay went to the Native American camp near the ranch and demanded that some of the men there procure a Native American woman for him to sleep with. When the Native American men refused, Clay shot and killed a man who was apparently the son of Ash Meadows Charley. A posse of Native American men from Pahrump accompanied the sheriff in pursuit of the killer (Rhyolite Daily Bulletin, vol. 1, no. 4, September 26, 1907, p. 1, col. 2; Bullfrog Miner, vol. III, no. 27, September 28, 1907, p. 1, col. 2). In 1909, "Indian Henry," the brother of M.M. Beatty's Native American wife, was killed in Pahrump by two Native Americans: John Scott, a son of Ash Meadows Charley, and Ed Bruce. The killing was reportedly linked to Indian Henry's failure to honor traditional burial customs. Indian Henry had continued to use a wagon belonging to the Black family after Bob Black had killed other members of the family two years earlier. According to tradition, the wagon should have been burned in honor of those deaths (Bullfrog Miner, vol. V, no. 18, July 24, 1909, p. 4, col. 1; Inquest File of Indian Henry, 1909). 
1910-19 Perlod The 1910 census enumerated 54 Native American people in the Johnnie precinct, encompassing both Ash Meadows, Pahrump, and the Johnnie area, which lies between Pahrump and Ash Meadows (1910 Nevada census rolls). A map titled "Pahrump Valley Ranch, 1916 and $1917^{\prime \prime}$ shows a Native American village located near the pond and swimming pool, and about three quarters of a mile from the main ranch buildings, which included a hotel (Lynch, 1978:89).

1920-29 Perlod The literature review did not locate documentation regarding Native American occupancy in Pahrump Valley during the 1920s. More extensive sampling of Nevada and California newspapers for this period would be expected to document the activities of Native American people in the area during this period.

1930-39 Perlod A BIA report indicates that, as of 1937, there were five Native American families and about thirty Native American individuals living in Pahrump. Four families, comprising twenty-six individuals, were studied. No population data are provided for the fifth family (TC-BIA, 1937b:17). The report indicates that $23.1 \%$ of the aggregate cash income for the four families studied came from the "Sale of Wild Foods" (TC-BIA, 1937b:17). The report states that during the summer months most of the families left the camp to work on ranches; some on nearby ranches, others at a greater distance (TC-BIA, 1937b:16).

1940-49 Period The 1940 census enumerates a total of 43 persons in the category "Other Races" (other than "White" or "Negro") for Beatty township, which encompassed all of southern Nye County. Many of these 43 persons can be presumed to be Native Americans, some of them living in Pahrump Valley, but the census enumeration for 1940 will remain sealed until 2012 (1940 Census). In 1947, the Nye County Sheriff went to Pahrump to investigate a report that three Native American girls living there had been shot with poisoned arrows. The sheriff discovered that Shoshone and Paiute people in Pahrump had been observing a cry dance honoring a Native American girl who had been killed there a year earlier. Native American participants believed that Bessie Shaw, a medicine woman from Beatty who was participating in the ceremonies, had magically shot the girls in response to a failure to follow proper ceremonial procedures (Goldfield News and Beatty Bulletin, vol. 44, no. 15, August 22, 1947, p. 1, col. 4).

Perlod Since 1950 Native American people were still living in Pahrump in the 1970s and 1980s. In 1971, two grandnieces of Chief Tecopa, both residents of Pahrump, were among the participants in an official ceremony to dedicate a monument to Chief Tecopa at the Pahrump cemetery. A photograph shows them seated on the speakers' platform (Lynch, 1971:191). in 1987, the Pahrump Band of Paiutes filed a petition with the BIA for federal acknowiedgment as an Indian tribe (Federal Register, vol. 52, no. 237, December 10, 1987, Notices, p. 46842). More extensive sampling of Nevada and California newspapers would be expected to uncover additional published documentation of Native American occupancy and activities in Pahrump Valley since 1950.

\section{Permanently Occupled Springs North and East of Yucca Mountain and Fortymlle Canyon}

To the north and east of Yucca Mountain are several springs that were used by Native American people in pre-contact times and after contact well into the twentieth century. These springs include Tippipah Spring and Toboban Spring on the slopes of Shoshone Mountain; Cane Spring on the slope of Skull Mountain; the Ammonia Tanks, Captain Jack Spring, Whiterock Spring, and Oak Spring around the southern end of the Belted Range; and nu- 
merous other smaller springs and water catchments. Some of the springs were occupied year-round, others were occupied seasonally, and others were used on a regular but intermittent basis. Although Native American people used and inhabited these spring sites, the springs in the area north and east of the culture resources study area do not form a core area comparable to Ash Meadows or Oasis Valley. The arc of springs north and east of Yucca Mountain are not concentrated together in a single basin and do not provide a concentrated water resource sufficient to support several Native American villages in close proximity.

The first documentation of Native American use of the springs north and east of the Nevada Test Site was by the emigrant parties who crossed in 1849 what is now the Nevada Test Site. William Lewis Manly, John Rogers, and Sheldon Young all recorded numerous indications of Native American occupancy and use in this area. The emigrants saw Native American people at several points (Manly, 1928:135,139,140) and captured Native American people on at least two occasions to obtain information about water sources (Manly, 1928:137; Nusbaumer, 1967:36). The emigrants found food cached in caves (Manly, 1928:148) and they found that Native American people had made beneficial improvements at many springs. At one spring they found Native American people engaged in cleaning accumulated sand out of the spring, at another they found a rock cover over the catchment, while at still another they found a clay catchment constructed under a seep on a canyon wall (Manly, 1928:134-135,137,148,160; Nusbaumer, 1967:36). Native American people forcibly detained by the emigrants gave the emigrants directions to the location of springs in the southwesterly direction the emigrants were traveling. One of the springs to which the emigrants were directed was apparently Whiterock Spring (Long, 1941:174-176).

Aboriginal agriculture of corn and squash is documented as having been practiced a Native American rancheria at Cane Spring when the first Euroamericans known to have traveled through the Nevada Test Site area arrived there in 1849 (see Maps 4 and 5). A party of Jayhawker emigrants with William Lewis Manly and John Rogers as its scouts stumbled upon a Native American rancheria at Cane Spring and noted a comfield that had already been harvested. When they arrived at the rancheria, Manly and Rogers were given a handful of corn by one of the Native American people living there (Manly, 1928:151). While Manly and Rogers rejoined their party and led it to the spring, the Native Americans fled, apparently taking their store of corn with them. The Euroamericans camped at the spring for over a week and discovered a cache of harvested squash, which they consumed (Manly, 1928:148,151,156; Nusbaumer, 1967:38,40,42; Rogers, 1894:64). Two days after leaving the rancheria, some of the party's oxen where shot with arrows. Manly and Rogers concluded that this was retaliation for the party's having eaten up the cache of squash at the rancheria (and presumably also for the impact of the party's livestock on the plant resources at the spring) (Manly, 1928; Rogers, 1894).

Native American occupancy and use of the springs in the area north and east of the Nevada Test Site is not well-documented in Euroamerican sources. The arc of springs, and the area around them, never attracted substantial permanent Euroamerican settlement. Euroamericans saw this area as a forbidding, arid back country, as evidenced by the wellpublicized sufferings of the Euroamerican emigrants who crossed the area in 1849. Euroamerican uses of the area were mainly temporary uses by prospectors, hunters of wild horses, bootleggers, and outlaws on the run. A few Euroamerican livestock ranching operations came and went at some of the springs. In the late 1800s, the freight and mail stagecoach route from Salt Lake City to southern California crossed the Nevada Test Site area. 


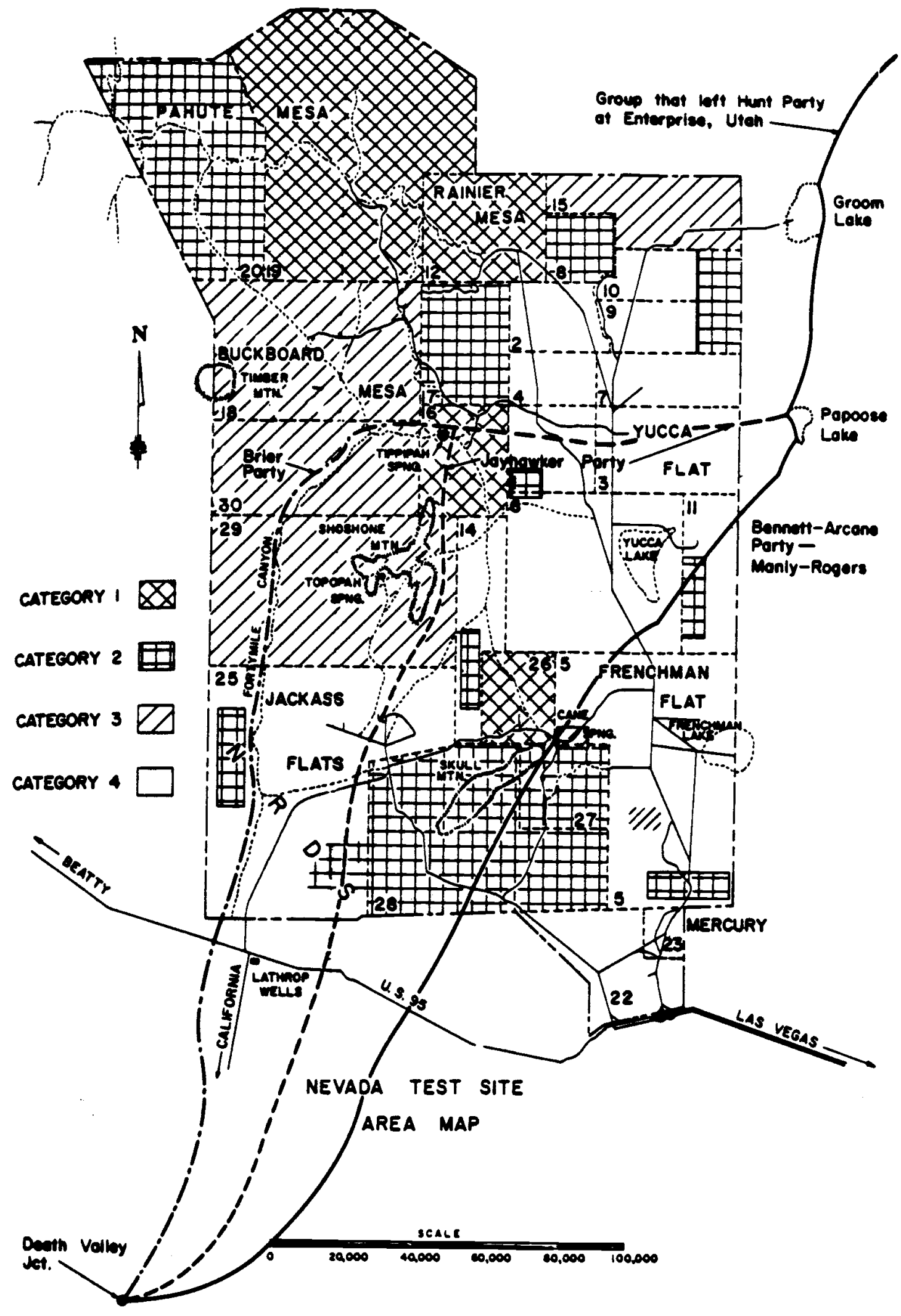

Map 4. Routes of the Forty-Niner Emigrants (Worman, 1969). 


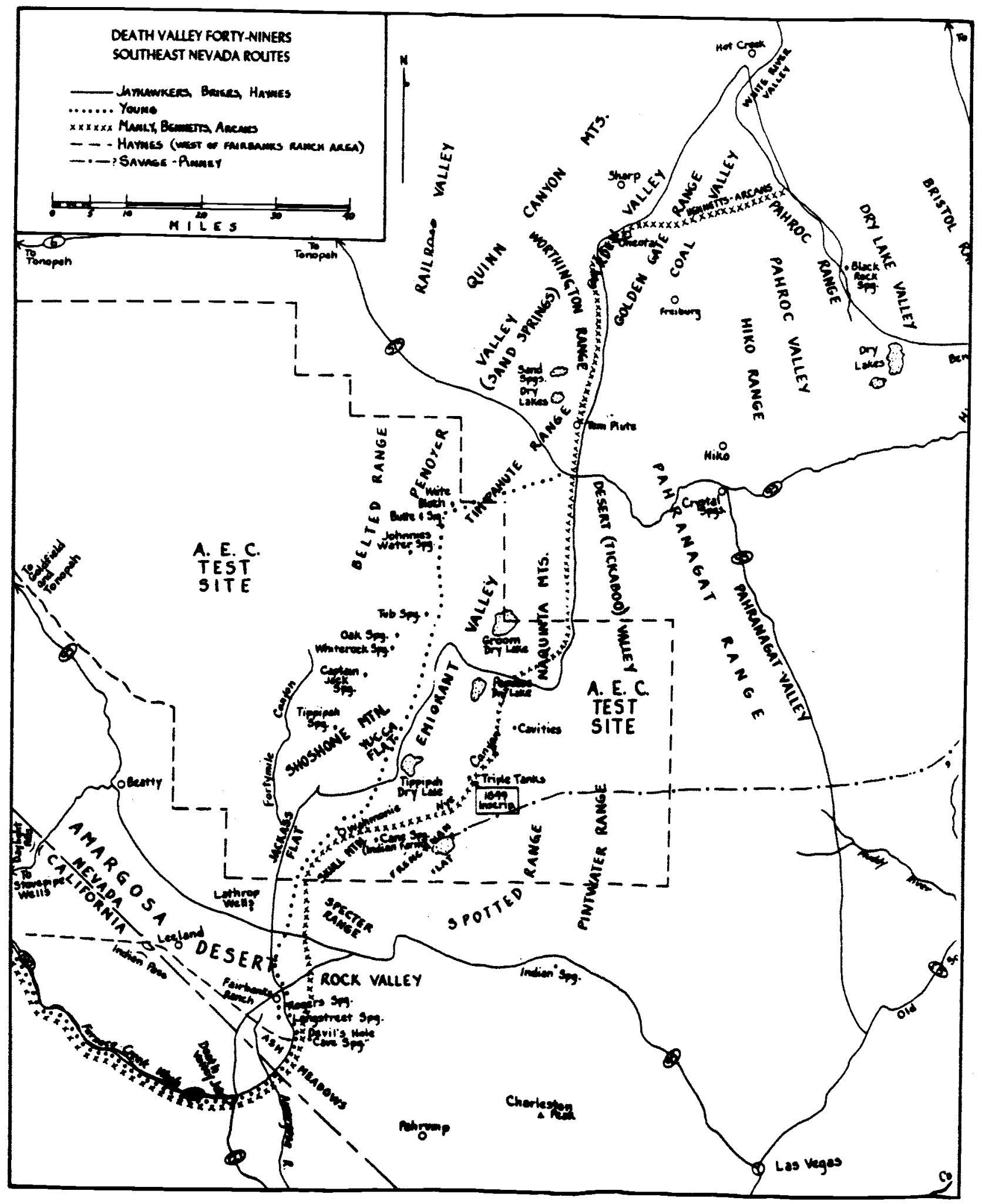

Map 5. Routes of the Forty-Niners (Koenig, 1984). 
Whiterock Spring, Cane Spring, Tippipah Spring, and an unspecified location in Fortymile Canyon are all identified as having been the sites of relay stations along the stage route or routes during the period from about 1870 to 1900 (Pippin and Zerga, 1983:54,57; Worman, 1969:12-15; NTS News, vol. VII, no. 2, January 24, 1964, pp. 4-5). There were a few smallscale mining operations in the region, most of them involving limited production and few of them in operation for more than a short time. There was an ephemeral boom of prospecting and mine development work near Cane Spring in 1928. After the discovery of gold in the Skull Mountain area, the camp of Wahmonie was established. It reached a population estimated at between 1,000 and 2,000, and then emptied out, all in the span of a few months. During its existence, the camp was supplied with water from Cane Spring (Koenig, 1984:90).

None of these Euroamerican uses led to any substantial permanent Euroamerican settlements in the area. Thus, it is not surprising that little documentation of this region exists in Euroamerican sources, and that Euroamerican sources yield very limited information about Native American people's occupancy and use of the area.

Based on his interviews with Native American people in Oasis Valley in the 1920s and 1930s, particularly with the interviewee he identified with the initials "TSt, "Steward documented that Native American people had winter camps at many of the springs to the north and east of Yucca Mountain and Fortymile Canyon. "TSt" stated that in his youth, in the late 1800s, Native American people were living at winter camps at the following locations: (1) Tunava at Whiterock Spring, (2) Wi:va at Oak Spring, (3) Kuikun at Captain Jack Spring, (4) Tupipa at Tippipah Spring, (5) Pokopa at Topopah Spring, (6) Pagambuhan at Cane Spring (7) Wuniakuda near the Ammonia Tanks, (8) Mutsi near "Tanks", and (9) Sivahwa near Small Tank (Steward, 1938:93-95). "TSt" gave the names of the families, the individuals, and the inter-relationships of the Native American people he identified as living at these springs (Steward, 1938:93-95).

Steward's data indicate that some families apparently made their primary residence at one of these springs. Other families apparently resided at one of these springs only during the winter season. Still other families came to the area and used the springs only during the fall season. In the fall, rabbit drives on the flats, pinyon nut harvesting on Shoshone Mountain, wild grain harvesting at a variety of locations, and a fall festival held in some years in the Ammonia Tanks area drew people to the area (Steward, 1938:93-99). Steward's primary interest was in reconstructing the locations and populations of Native American people prior to or at the time of the earliest Euroamerican settlers. It is not clear from the data Steward provided how much later the various sites were occupied by Native American families (Steward, 1938:93-95, map facing p. 58).

Belted Range people maintained sweat houses at Whiterock Spring and Oak Spring (Steward, 1938:96-98). In some years, fall festivals were held at Wuniakuda near the Ammonia Tanks, involving days and nights of dancing, gambling, and socializing, with people coming from Oasis Valley to participate. In other years, the fall festival was held in Oasis Valley and the Belted Range people came to participate in the festival there (Steward, 1938:97-99).

Captain Jack, the Native American man for whom Captain Jack Spring is named, reportedly occupied a rock shelter in the area of Whiterock Spring from the late 1800 s through the early 1900s, returning later to reoccupy the shelter and dying there in 1928. As of 1948, the shelter reportedly contained a hammered brass bracelet "of the type popular with Indian women during the 1850 s and 1860 s," several mealing stones, and a variety of rusted metal 
goods ("Archaeologist and Party in Survey of 40-Mile Country," Goldfield News and Beatty Bulletin, vol. 44, no. 50, April 23, 1948, p. 2, col. 4). Excavations of rock shelters in the vicinity of Captain Jack Spring in the 1960 s yielded both lithic and industrially produced artifacts (Worman, 1969:19-22,40).

A Native American burial located at Cane Spring was excavated by Frederick Worman in the 1960 s. The burial had already been vandalized, but screening the fill yielded 62 glass beads (Worman, 1969:14,136). There are archaeological remains of several Native American campsites in the vicinity of Cane Spring (Worman, 1969:12).

Excavation of two rock shelters near Whiterock Spring disclosed both blue and white glass trade beads (Worman, 1963:no page numbers). Artifacts at Whiterock Spring include the remains of a 1928 Buick (Worman, 1969:36). A Shoshone interviewee who resided at Whiterock Spring in the 1920s and 1930s identified another Shoshone man, now living at Duckwater, as having abandoned the Buick there.

In the vicinity of Tippipah Spring, there are archaeological remains of numerous Native American campsites (Worman, 1969:11).

\section{Yucca Mountain and Fortymile Canyon Area}

Events in the Yucca Mountain and Fortymile Canyon area are very poorly documented. Euroamericans regarded this area as a forbidding, arid back country. Euroamerican uses of the area were mainly temporary uses by prospectors, hunters of wild horses, and outlaws. Several mines were operated in the Fortymile Canyon area, most of them small-scale and/or short-lived. The principal, more permanent use was the freight and mail stage route that ran through Fortymile Canyon in the late 1800 s, with a relay station located somewhere in the Fortymile Canyon area. There has never been any significant permanent settlement of Euroamericans in this area. Thus, it is not surprising that there is little documentation concerning the region in Euroamerican sources, and not surprising that Euroamerican sources provide very little information regarding Native American people's occupancy and uses in the area.

In about 1880 , a prospector reportedly entered the Fortymile Canyon area to search for the location of ore he had been shown by one of the emigrants who had crossed the Nevada Test Site area in 1849. The prospector was looking for a spring with a cottonwood tree near a conjunction of Native American trails. As he neared the location, he was reportedly confronted and driven away by Native American people (Carrara Obelisk, vol. 2, no. 1, May 8 , 1914 , p. 6, col. 3).

In the early 1930s, Steward's interviewee, "TSt" of Beatty, stated that during his childhood in the late 1800s, Native American families from the Oasis Valley area had harvested Salvia on Bare Mountain and Yucca Mountain (Steward, 1938:96). In July, families from the Belted Range harvested hu:gwhi, a large grass seed resembling wheat. Later the families harvested rye grass (Elymus) seeds in the area around the Ammonia Tanks (Steward, 1938:96). In September, Oasis Valley people went to the Belted Range to harvest pinyon nuts (Steward, 1938:96). Fall rabbit drives were held on the flats south of Whiterock Spring, "under the direction of Wangagwana, the local chief." Rabbit drives lasted about a month and often included participants from Ash Meadows, Death Valley, Lida, and the Kawich Mountains (Steward, 1938:97-98). 
The Carrara newspaper reported that a Native American man who had been involved in locating the Montgomery-Shoshone mine took some high-grade ore to a broker in Goldfield in 1912. He did not say where the ore came from, but was later trailed by interested parties as far as Oak Spring. They lost track of the Native American prospector in the Fortymile Canyon area (Carrara Obelisk, vol. II, no. 1, May 8, 1914, inside p., col. 3.)

A Native American burial was excavated in the 1960 s in the Pahute Mesa/Ranier Mesa area. Archaeologists recovered 1,311 glass beads and a skull with buckskin and basketry coverings (NTS News, vol. 7, no. 21, October 30, 1964, pp. 1,4,5,8). Other material was removed by vandals or amateurs before the excavation was completed. Several rock shelters on Pahute Mesa were partially excavated in the 1960 s and yielded both lithic and industrially produced artifacts (Worman, 1969:19-22,40). At the McKinnis site, located in the Timber Mountain area and overlooking Fortymile Canyon, surface surveys and limited, shallow test excavations yielded a wealth of Native American artifacts Worman, 1969:29-36,89116). Unfortunately, testing of nuclear devices has disrupted and left an overburden of up to 50 feet over the McKinnis site. Worman was only able to carry out limited test excavations before the site was obliterated. "Big George's Cave" in Cat Canyon in the Buckboard Mesa/ Timber Mountain area contained hundreds of petroglyphs, including petroglyphs on small rocks (Worman, 1969:27).

\section{Conclusion}

Native American occupancy of the core areas to the west and south of the culture resources study area is well-documented. Native American occupancy and use of the arc of springs to the north and west of the study area is documented in a limited way. Not surprisingly, there is very little documentation concerning Native American occupancy and use of the Yucca Mountain and Fortymile Canyon area. Euroamerican sources provide little documentation of Native American activities in this area, because there has never been any substantial permanent Euroamerican settlement there. While there were producing mines in the area, none were big producers and many were short-lived. Throughout most of the area, Euroamerican use was ephemeral use by prospectors, hunters of mustangs, and outlaws. The area remained a forbidding, arid, marginal back country zone for Euroamericans. Thus, for information on Native American activities in the culture resources study area, it is logical that interviews with Native American people be used as a primary source of data. 


\section{CHAPTER FIVE}

\section{Keyword Chronological Data Base}

\section{Introduction}

This chapter provides a detailed chronology of events, activities, and places bearing upon the identification of Native American peoples and their patterns of occupation and use in the study area and vicinity. This data base offers detailed documentation for the analytical summary of chronology presented in Chapter Four and makes possible a fairly detailed tracing of the changes and continuities in Native American activities in the study area and vicinity. The bulk of the included items refer specifically to the activities of Native American people. Also included are items that do not refer specifically to Native Americans, but concern mining activities, railroad construction, diversion of springs to towns and mines, and other development activities that had major impacts upon local Native American occupancy, use, and activities.

This Keyword Chronological Data Base is chronologically organized and divided into five subsections: (1) Pre-Contact and Early Contact Period, Undated; (2) Late 1800s and Early 1900s, No Exact Date; (3) Post-Contact Period to 1900; (4) Post-Contact Period Since 1900; and (5) Twentieth Century, No Exact Date. Items in the third and fourth sections are chronologically organized by year. Each item in the data base is preceded by italicized keywords and followed by a citation referring to the bibliography. Five maps and six photographs relevant to some items in the data base are presented at Page 156.

Data from newspapers have been cited as fully as possible, both in the text and in the bibliography. This has been done to facilitate the re-accessing of original sources by interested readers. Early twentieth century small town newspapers often printed out-of-sequence, erroneous volume numbers, issue numbers, and issue dates. Pages were often not numbered. In microfilm reprints, it is frequently not clear what the original sequence of pages may have been, if the pages were not numbered. To provide as much assistance as possible for readers who may wish to examine any of the newspaper items cited in this report, newspaper citations in most cases contain all of the following: (1) both the date of publication and the volume and issue number, if the original contains both; (2) the page number (if pages were not numbered in the original, in most cases page numbers have been assigned corresponding to the sequence of pages in the microfilm print); and (3) the column number. In many cases, the title or header of the article or item is also included in the citation.

It is believed that the disadvantage of having lengthy citations in the text is outweighed by the advantage of providing several cross-referencing data points to facilitate the process of locating the original newspaper sources by readers who may wish to do so.

\section{Pre-Contact and Early Contact Period, Undated}

Paiutes: Pahute Mesa/Ranier Mesa: burial - Map in Worman (1969) shows location of "Paiute Burial" in the Pahute Mesa area. [Worman 1969:2]

Paiutes: Pahute Mesa/Ranier Mesa: burial site - "Test Site employees Ray Hansen, Jim Christensen and Richard Lamb, all of REECo's Architect and Engineering Department, discovered the burial site. The men were stationed in the forward area....on a rock-strewn slope about 100 feet above the floor of a small 
valley. Four talus boulders formed a narrow crack about eight feet long and three inches to two feet wide....the skull and basketry fragments were brought to Mercury....The Sheriff's Office notified Fred Worman of LASL (he is official AEC archaeologist for NTS) of the find and turned the skull over to him... Unfortunately, word of the discovery of the burial site had gone out over Test Site radios and some amateur archaeologist...cleaned out the rest of the burial site before Worman and Tuohy could investigate it." Following are excerpts from headers under photographs accompanying the article quoted above:

a. $\quad$ "Ray Hansen (left) shows Chief Deputy Sheriff Bob Revert the Indian burial site he discovered with other Test Site employees in a remote area of NTS."

b. "Pat Provo and Fred Worman examine the skull in the NTS News office." Archaeologists Worman and Tuohy carefully screened debris from the excavation and found 1,311 glass trade beads. Positive association with the interment was established when a red and white trade bead tumbled out from the foramen magnum of the skull.

c. "The skull and basketry fragments being removed from the burial site. They were given to the Nevada State Museum and Curator Donald Tuohy reports: 'Preliminary studies of the brain case and mandible indicate that the individual was a child, probably less than ten years old at the time of death....Small bits of tissue still adhered to the skull... The skull and mandible apparently were placed inside an open-work twined carrying basket. The basketry fragments are heavily coated with pine pitch; they are from a stiff twined basket made from peeled willow....Adhering to the cranium was a fragment of buckskin. Proper archaeological excavation of the burial site would have yielded valuable information on orientation of the burial, but other remains and artifacts were removed in an unauthorized excavation before Archaeologists Tuohy and Worman got to the site." [NTS News, vol. VII, no. 21, October 30, 1964, pp. 1,4,5,8]

Paiutes: Cane Spring: burial - Worman briefly discussed his excavation of a "Paiute grave." "Historical artifacts included 62 whole or broken beads found by screening the fill from a Pailute grave 'dug' by some past vandal. Photographs of the 36 best samples are shown in Plate 8-B." A small map on page 14 showed the location of the 'Paiute Grave.' [Worman, 1969:14,136]

Archaeological sites: Nevada Test Site: burial: Paiutes - Donald R. Tuohy, Nevada State Museum Curator of Archaeology noted that as of 1969: "The archaeology of the Nevada Test Site, a federal preserve embracing much of southern Nye County, is little known. A systematic survey of the archaeological resources has never been undertaken, and it may be safely assumed that hundreds of archaeological sites have already disappeared beneath highways and other installations. The archaeological potential of the Nevada Test Site is high. The full range of archaeological sites from habitation caves to burial sites and petroglyph sites may be found on the preserve. Artifact preservation is excellent in some of these shelters. During a one-week visit, the author visited seven archaeological sites and partially excavated two of them. The excavated sites, a burial site and a cache site yielded cultural materials, open work twined basketry, glass trade beads, digging sticks, and one-piece hardwood arrows. The presence of small triangular projectile 
points, small side-notched projectile points, and Southern Paiute utility Brown Ware potsherds and vessels...also indicates Southern Paiute occupation and utilization of the Test facility. At the same time, the presence of Pueblo pottery types, North Creek Black-on-gray and Washington Corrugated indicates trade with Pueblo groups, or actual occupation of the Test facility by these people....Tuohy says it seems paradoxical that an area set aside for scientific purposes lacks a planned study of the prehistoric cultural landscape that might be obliterated by missile age developments." [NTS News, vol. VII, no. 21, October 30, 1964, pp. 5,8]

Archaeological sites: Nevada Test Site: rock shelter - Worman provided details on numerous archaeological sites on the Nevada Test Site, including latitudinal and longitudinal coordinates of the locations; listings, tables, and discussions covering excavated materials; and photographs of the sites and many of the artifacts.

Sites described include:

a. Tippipah Spring - "Prehistoric campsites surround the spring to a distance of approximately one-half mile." As of 1969, there had been no excavations at the site, but material found on the surface included Southern Paiute Brownware sherds, knives, projectile points, and a scraper. [Worman, 1969:10-11]

b. Cane Spring - "Indian campgrounds lie on hillops and gentle slopes to the east, west, and northeast....Three rock-outlined circles were found...on cleared bedrock....abundant materials were recovered from loose sand at all levels... The recovery of 122 artifacts in the small portion of the one campsite tested is a good prognostication of the amount of material that must remain.... Artifacts excavated from the limited sample included 62 glass beads (from a grave site). Artifacts included points, knives, scrapers, pendant, drill, gravers, metates, and a lead bullet." Worman suggested that the rock circles may have been hunting blinds. "The circles are smaller than the 'sleeping circles,' described by Rogers, from the San Dieguito culture. I found lying down in them, on the hard rock, extremely uncomfortable after a short time. However, placing shrubs between the rocks converted the structures into excellent blinds where a hunter could wait for animals..." [Worman, 1969:12-15,32]

c. Topopah Spring - "Artifacts and flakes were found throughout the area." [Worman, 1969:15-16]

d. Fortymile Canyon area - Unnamed rock shelters in the Buckboard Mesa Quadrangle "in a side canyon to the north of the road into Forty Mile Canyon...This area has a number of small shelters...and may deserve further archaeological investigation. Two shelters, showing evidence of occupation, were chosen as being representative... Both shelters had been disturbed previously as indicated by small piles of screened fill in front of the openings..." Worman 1969:16-18] 
e. Pahute Mesa - Among six rock shelters in the Timber Mountain area were:

- Rock shelter \#1, which had already been disturbed. "Materials from this shelter, entirely of a historical nature, consisted of eight trade beads."

- Rock shelter \#2, which yielded both lithic artifacts and industrially produced artifacts including a rivet, a nail, a boot lace hook, and glass beads, as well as a pumice pipe and a shell bead. "A semicircle of stones in front appears to be the remains of a small pen, possibly for confining a burro or two."

- Rock shelter \#3. "The fill was one inch deep at the maximum, and the only artifact was a four-hole metal trouser button." [Worman, 1969:19-22]

f. Big George's Cave, Buckboard Mesa/Timber Mountain area - There is a large rock shelter on the south side of Cat Canyon. "A well-made wall has been built across the front of the cave to act as a windbreak and to create added comfort for the inhabitant....Artifacts, hundreds of petroglyphs (some even on small rocks) and an open site...immediately above the cave serve as an indication of considerable Indian occupation....Materials shown in Plate 24 and described in Table XVI were all removed from a 3 foot by 3 foot by 4-inch deep test pit...A splinter awl and a blue, hexagonal trade bead." [Worman, 1969:25-27]

g. Unnamed site, Buckboard Mesa Timber Mountain area - "[A] campsite on a flat area in the bottom of the north end of Forty Mile Canyon.... The site is about 100 yards in diameter....Surface artifacts were present but not abundant." [Worman, 1969:28]

h. Paiute Pinon Cache, Timber Mountain $Q$ area - "The opening of the cache was covered with mud and interwoven branches....An 18-inch circular hole opens into a circular cavity 6 feet in diameter and about 14 inches high." The cache contained a tin pan. [Worman, 1969:29]

i. McKinnis site, Timber Mountain/Fortymile Canyon area - The McKinnis Site is located on the east flank of Timber Mountain on a flat overlooking Fortymile Canyon. This site is now covered with an overburden up to 48 feet deep created by "Project Buggy," part of the Plowshare Program. "Fortunately, the surface of this area was well examined in advance of the event, and it was possible to do some trenching.... Only a small portion of the archaeological area remains uncovered.... Notification of the archaeological nature of a part of the site came to me from William McKinnis of LRL, who had picked up a large number of artifacts....Saller collections were also made by John M. Townley of the AEC Nevada Operations Office and Donald G. MCGuffin of LRL. All three men were very cooperative and loaned me their collections...Proveniences are not given for the materials which I collected. By the time I became aware of the site, it was a matter of surveying, as rapidly as possible, mainly because of the impending program.... a 50 - by 4foot trench and three 5 - by 5-foot test pits were dug...maximum depth was 8 inches."

Artifacts from Worman's surface survey and shallow excavations at the McKinnis site (not including collections made by other individuals) included: 
- 85 pottery sherds (including 81 of Southern Paiute Brownware)

- 154 projectile points of various types

- 158 knives or partial knives

- 34 scrapers of various types

- 4 drills, 2 choppers, 2 graver, 1 axe or maul

- 1 shaft polishing stone, 2 crescents [Worman, 1969:29-36,89-116]

j. Whiterock Spring - A stone cabin and corral remain, as well as the body and chassis of a 1928 model Buick (Worman, 1969:39-40). [Field interviews indicate that the Buick left at Whiterock Spring was left there by a Western Shoshone man now living at Duckwater (Ted Shaw. Personal communication).]

k. Captain Jack Spring - "Several types of Indian sites were represented at short distances from the spring. Two rockshelters had been used. Several small sites were protected by pinon trees. Artifacts from the site included both lithic materials and enamelware, canteens, pots, and pans of industrial manufacture." [Worman, 1969:40]

Archaeological sites: Nevada Test Site: rock shelter - Rodgers Rock Shelter, on Ranier Mesa, about two miles from Whiterock Spring, was excavated by Frederick C. Worman in 1962. Among the artifacts recovered were two types of glass beads, indicating the rock shelter was used in the post-contact period. There were 17 white opaque glass beads identified as "of the type known as the 'seed' bead, an early trade item in the northwest...introduced into the Plains area before 1850" and 8 dark blue glass beads known as "Hudson's Bay Beads" that were "among the earliest used in the Canadian trade. These beads could have been introduced into NTS at any time after 1850 through trade with tribes to the north." Worman, 1963:no page numbers]

Archaeological sites: Fortymile Canyon - Ceremonial rock circles in Fortymile Canyon are shown in photograph. [Koenig, 1984:71]

Archaeological sites: Nevada Test Site: rock shelters - Worman stated that "two excavated rock-shelters and four observed ones were all occupied, at least sporadically by traveling bands, into fairly recent times. [Worman, 1963:no page numbers]

Archaeologists: Cane Spring: camps - Numerous Native American campgrounds were located on hills to the east, west, and northeast of Cane Spring. Test diggings revealed an abundance of artifacts. [Worman, 1969:12-15]

- Native Americans: central Nevada: aboriginal agriculture - Steward said that in pre-contact times "wild seeds were sown broadcast in central Nevada but neither irrigated nor cultivated....The main species sown were uep: (Cheno-podium album, goosefoot, or lambs-quarters) and kuha or kuhwa (Mentzelia dispersa)." All groups burned brush to facilitate growth of wild tobacco and sometimes of other wild-seed plants. [Steward, 1941:232]

Paiute: Ash Meadows: aboriginal agriculture - Steward said that Southern Paiute at Ash Meadows practiced "true horticulture" in "pre-Caucasian times." He recorded the following as "Native plants" at Ash Meadows: 
a. Corn.

b. Pumpkins or squash.

- Padan'a, a crooked-neck squash occurring in all colors.

- Hama'tats, a round, deeply furrowed, greenish or brownish variety.

c. Beans. Tuwunt', a large, round, green variety.

- Kaka'-damudi, black-eyed beans.

- Wa'samudi, brown beans. [Steward, 1941:231-232]

"Small gardens, cultivated by both men and women, were made wherever there was water. Moist ground near a stream was preferred; otherwise land was irrigated. Weeds, of which AH said there were formerly few, were pulled by hand or by means of the digging stick; mesquite might be burned off. Seeds were dropped into holes punched with the digging stick. Corn was shelled and kept in a flat-bottom pot....Pumpkins and squash were cut into long strips, which were tied together, dried and stored in dome-shaped brush houses. Beans were kept in buckskin bags or pots" (Steward, 1941:231-232). According to Steward, "The northwestem limit of aboriginal horticulture was probably Pahrump Valley and Ash Meadows. Crops grown were corn, squash, beans, and sunflowers.

Cultivation...entailed planting small fields in moist soil near streams and using a little irrigation. The cultivated fields at Manse and Pahrump in Pahrump Valley were scattered in small plots. Apparently there was insufficient arable land for all families to own plots. Those without land traded wild plant foods for cultivated crops. AH seemed to think that these foods were freely distributed rather than actually borrowed." [Steward, 1938:183]

Paiutes: Ash Meadows: Pahrump: aboriginal agriculture - Steward indicated there was aboriginal horticulture of corn, squash, beans, and sunflower in Ash Meadows and Pahrump. [Steward, 1938:183]

Southern Paiute: aboriginal agriculture - Fowler and Fowler noted that "Southern Paiute horticulture antedated White contact. Escalante in 1776 reported small fields of maize and the use of irrigation ditches on Ash Creek...Jebediah Smith reported Paiute farms along the Colorado River in 1826 and there are frequent references to Paiute farms and irrigation ditches and dams in the journals of early Mormon settlers in southern Utah and southern Nevada." [Fowler and Fowler, 1971: 283]

Native Americans: Pahranagat: agriculture - According to Davis, "The Pah-ran-agat Indians are a branch of the Ute family and derive their tribal appellation from the cultivation of the watermelon, which in their language is called pah-ran-a-gat (pah meaning water, and ran-a-gat meaning melon or vine-growing). As the prospectors first entered the country occupied by them they found this band inclined to peace and engaged after their rude manner in tilling the soil. Although they raised a small quantity of wheat and some corn, their principal crop was the squash. A diminutive species of sunflower was also planted for the seeds it yielded, and some watermelons were also to be found in their cultivated patches. Grass seed was also largely used by them as food. To irrigate the land under tillage they had constructed several ditches which were creditable to these primitive engineers." [Ingalls, 1913:187] 
- Paiutes: Muddy River area: aboriginal agriculture - "The Piutes did little or no farming. They grew some corn, beans, and squash, with no soil preparation or system as they didn't have any tools to work with." [Hafner, 1967:8]

Paiutes: Owens Valley: aboriginal agriculture - Steward concluded that irrigation of wild plants in Owens Valley was of aboriginal origin. [Steward, 1930:156; Steward, 1970:123; Steward, 1977:376-377]

- Paiutes: Owens Valley: aboriginal agriculture - Steward's informants stated that irrigation in Owens Valley began in aboriginal times. [Steward, 1930:149-156; Steward, 1933:247-249]

Paiutes: Owens Valley: aboriginal agriculture - Lawton concluded that irrigation by Owens Valley Paiutes "was almost certainly of indigenous origin and that they were engaged in agriculture by definition." It was suggested that ditch irrigation of wild plants may have extended over a broader area of the Great Basin than just Owens Valley. [Lawton et al., 1976:15]

Paiutes: Owens Valley: aboriginal agriculture - Busby et al. (1979) stated that "[d]eliberate irrigation was used by the Owens Valley Paiutes to increase the natural yield of several root and seed plants through the maintenance of community owned diversion dams and ditches.... The honorary position of head irrigator (tuvaija) was filled each spring by election at a popular assembly....Irrigation was primarily directed towards two plants, tupusi and nahavita, in the irrigated plots, although the overflow water also irrigated other wild seeds and tubers (Steward, 1933:247)....Nahavita and tupusi have recently been classified as the wild hyacinth (Dichelostemma pulchella) and yellow nut grass (Cyperus esculentus) by Lawton et al. (1976:33-36) after an intensive investigation of irrigation among the Owens Valley Paiute.... Lawton et al. concluded that a well developed agricultural system existed in Owens Valley at the time of white contact focused on the irrigation of 'root crops' rather than the traditionally grown species of other Native American conventional agricultural systems as in the rest of North America. Operating as an adjunct to the hunting and gathering of wild food items, the system was probably of an independent origin." [Busby, Findlay, and Bard, 1979:164-165]

\section{Late 1800 s and Early 1900s, No Exact Date}

Shoshones: Paiutes: territories - According to Lingenfelter, Shoshones occupied the northern half of Death Valley, the Panamints and Grapevines, and the upper Amargosa River basin from Ash Meadows north. Paiutes occupied Death Valley south of Fumace Creek and the southern reaches of the Amargosa River.

Kawaiisu occupied the extreme southern end of Death Valley and of the Panamint Range. Paiutes occupied Death Valley. Actual boundaries were "ill-defined," blurred by intertribal marriages. [Lingenfelter, 1986:16]

Oasis Valley: Belted Range: villages - Julian Steward conducted his ethnographic fieldwork with Paiutes and Shoshones, including informants from the region of Beatty and the Belted Range, from 1926-1935. He generally attempted to reconstruct the patterns of use and occupancy typical of an earlier period, drawing on the knowledge of older informants. For the Beatty area villages, Steward presents a reconstruction for the period of "1875 or 1880." Some of these pattems of use 
and occupancy continued up to the time of his interviews and beyond, but Steward does not specify to what degree there had been changes or continuities, since his interest was in constructing a portrait of "traditional" cultural patterns. His data derive from ethnographic interviews with Paiute and Shoshone informants conducted between 1926 and 1935. [Steward, 1938: preface (no page number)]

Paiutes: California tribal groupings - Paiute tribal groupings in California included Saline Valley Shoshone; Koso Valley Shoshoni; Owens Lake and Lone Pine Paiute; Fish Springs Paiute; Independence Paiute; Big Pine Paiute; Deep Springs Valley Paiute; and Bishop, Laws, and Round Valley Paiute. [Steward, 1933:236-7]

Shoshones: Paiutes: mixed intermarriage of Shoshones and Paiutes: mixed population - Steward viewed "southern Nevada from the Amagrosa (sic) Desert eastward to the Pintwater Range and possibly beyond" as Shoshone territory, but noted that "it is probable that the population along the area of tribal contact was a mixture of Paiute and Shoshoni like that at Ash Meadows." Steward documented that there was intermarriage between Shoshones and Paiutes in the Beatty area, in the Belted Range area, and in the Ash Meadows area. [Steward, 1938:93,94-95]

- Shoshones: Oasis Valley: Belted Mountains: villages - Steward listed fifteen locations of winter camps in the region of Beatty and the Belted Mountains. Most of the locations were clustered around Beatty and the Oasis Valley and in the Belted Mountains "because of the unusual number of springs" in these areas. Steward notes that relatively detailed information is available for the Beatty and Belted Range areas due to the clustering of villages in both. The Beatty people and the Belted Range people were linked together through "considerable intermarriage and some cooperation." The Beatty people also "associated occasionally" with Death Valley people. The Belted Range people associated with the people of the Kawich Mountains. [Steward, 1938:93]

Oasis Valley: villages - According to Steward, Oasis Valley people had winter camps at the following locations:

a. Indian Camp at the head of Oasis Valley.

b. Howell Ranch near' Springdale.

c. Hu:nusu, later Burns Ranch, near Goss Springs.

d. Ta:kanawa, later Hick's Hot Springs.

e. Three camps at Sakainaga, at the mouth of Beatty Wash.

f. Pa:navadu at the mouth of Beatty Wash.

[Steward, 1938:93-95, map facing p. 58]

Belted Range: villages - According to Steward, Belted Range people had winter camps at the following locations:

a. Wuniakuda, a rock shelter near the Ammonia Tanks.

b. Mutsi, near waterholes called "Tanks" on USGS maps.

c. Sivahwa, "Small Tank" on USGS maps.

d. Tunava, at Whiterock Spring (where the chief of this area lived).

e. Wi:va, at Oak Spring.

f. Kuikun, at Captain Jack Spring.

[Steward, 1938:93-95, map facing p. 58] 
Cane Spring: Tippipah Spring: Topopah Spring: camps - According to Steward, there were winter camps of Native American people at:

a. Tupipa, or Tippipah Spring.

b. Pokopa, or Topopah Spring (both Tippipah and Topopah are on the flanks of Shoshone Mountain).

c. Pagambuhan, or Cane Spring.

Steward notes that the camp at Cane Spring "was probably affiliated with Ash Meadows Southern Paiute as much as with Shoshoni and had a mixed population." [Steward, 1938:93-95, map facing p. 58]

- Shoshones: Oasis Valley: villages - According to Lingenfelter, Shoshones had several winter camps in Oasis Valley. The main camp was at Sakainaga on Beatty Wash about three miles from the later town of Beatty. Other nearby camps included Panavadu, Takanawa, and Hunusu. [Lingenfelter, 1986:2,20]

Shoshones: Belted Range: camps - At the southem end of the Belted Range were several camps, including camps at Tippipah Spring and Topopah Spring, totaling 40-50 people. [Steward, 1938:94]

- Shoshones: Panamint: village sites and camp sites - Grosscup (1977) lists 19 village sites and 14 camp sites for the Panamint Shoshones. [Grosscup, 1977:118]

Native Americans: Oasis Valley: camps - M.M. Beatty, Jr., stated that bands of Native Americans camped at his father's ranch (near the town of Beatty in the 1890 s and early 1900s). Several bands traveled the area, making their rounds between Beatty, Pahrump, and Furnace Creek, each band with 15 or 20 persons and its own headman. [Taped Interview with M.M. Beatty, Jr., November 1, 1968, Nevada Historical Society]

- Native Americans: Oasis Valley: study area - M.M. Beatty, Jr., stated that his father would take Native American youths who camped in the area around the Beatty ranch into the mountains to the east to capture and tame wild horses. [Taped Interview with M.M. Beatty, Jr., November 1, 1968, Nevada Historical Society]

- Shoshones: Oasis Valley: Belted Range: fall festival - Beatty area people celebrated a fall festival at Beatty in some years and at the Ammonia Tanks at the south end of the Belted Range in other years. Ash Meadows people also participated in festivals at these locations. [Steward, 1938:98,90]

Shoshones: Oasis Valley: northern Death Valley: hunting: fall festivals Shoshones of northern Death Valley sometimes joined people of the Oasis Valley area for rabbit drives and fall festivals. The two groups also intermarried. For example, in the post-contact period, one of Cold Mountain Jack's daughters (from northern Death Valley) married a man from the Beatty area. Joe Button's younger brother married Maggie from Sigai. After the marriage, the couple moved to Beatty. [Steward, 1938:86]

Shoshones: Oasis Valley: Belted Range: sweat houses - Sweat houses served as meeting places for people of neighboring camps. Sweat houses served as community centers. There were sweat houses at the head of Oasis Valley, at the mouth of Beatty Wash, at Whiterock Spring, and at Oak Spring. [Steward, 1938:98] 
Native Americans: Amargosa: Death Valley region: fall festival - The major con. munal social gathering for villages in Death Valley and along the Amargosa was the annual fall festival, which was held after the pinyon nut harvest and celebrated for several days "with a circle dance, feasting, gambling, and a mourning ceremony at which all the belongings of anyone who had died that year were burned." [Lingenfelter, 1986:18]

Shoshones: Oasis Valley area: wild plant harvesting - Steward noted that "the annual round of food seeking of the families near Beatty during TSt's [Steward's identifying initials for this informant] childhood required travel over an extensive area of about 1,300 square miles." [Steward, 1938:95]

Shoshones: Oasis Valley area: wild plant harvesting: Beatty area - People harvested Salvia on Yucca Mountain and Bare Mountain, rye and other grass seeds near the Ammonia Tanks east of the Belted Range, and pine nuts in the Belted Range. [Steward, 1938:36]

Shoshones: Beatty: pinyon nuts - The Beatty area people gathered pinyon nuts in the Belted Range and intermarried with people there. Beatty area people also intermarried with people in the Kawich Mountains. [Steward, 1938:96]

Shoshones: Oasis Valley: pinyon nuts - Oasis Valley Shoshones usually went to Shoshone Mountain and the Belted Range for pine nut harvesting. [Lingenfelter, 1986:20]

Shoshones: Oasis Valley: Belted Range: hunting - Oasis Valley area people had communal rabbit drives on Yucca Flats in the area south of Whiterock Spring, with visitors coming to participate from Ash Meadows, Kawich, Death Valley, and Lida. [Steward, 1938:97]

Shoshones: Belted Range: intermarriage of Shoshones and Paiutes: Panamint Joe Stuart - Panamint Joe Stuart was from a Belted Range village near the Ammonia Tanks. He "married a Paiute woman in the Charleston Mountains and lived with her," but later returned to the Beatty area "where he was 'chief' of the Shoshoni at the time of the Rhyolite mining boom." His oldest brother married a Paiute woman at Pahrump. His other brother married a Paiute woman at Indian Springs. [Steward, 1938:95]

Paiute: Pahrump: Ash Meadows: Las Vegas: pinyon nuts: territories - Steward said that for the Southern Paiute of Pahrump, Ash Meadows, and Las Vegas, "[p]ine-nut tracts were owned by men and inherited by their sons. A woman gathered on her husband's land. Trespass sometimes caused fights but usually resulted merely in verbal exchange. It was generally avoided, however, because owners were believed to practice witchcraft against trespassers. Permission to gather on a tract was readily extended to families which owned tracts in areas where the crop had failed. Thus, Shoshone people from Ash Meadows were often invited to pick on the Spring Mountains, and when the Spring Mountains crop failed, Paiute were invited to pick in the Shoshoni Mountains." [Steward, 1938:183]

Shoshones: Northern Paiutes: Lida Spring area - Most of the Shoshone in the Lida area lived at Pauwaha, now Lida Spring. Most of the Paiute lived at Tunava, now Pigeon Spring. Palmetto Dick, a Northern Paiute, was pakwinavi of all the people in the area in the late nineteenth century. [Lingenfelter, 1986:22] 
Paiutes: Shoshones: Ash Meadows: mixed population - People at Ash Meadows were a mixture of Shoshones and Southem Paiutes. [Lingenfelter, 1986:21]

Paiutes: Ash Meadows: Pahrump: fall festival - Steward reports that "in recent times" the location of the fall festival rotated between Manse, Pahrump, Las Vegas, and Moapa, with visitors coming from Beatty, Ash Meadows, Pahrump, Las Vegas, and other places as far distant as San Bernardino. According to Steward, the last such festival was held in the first few years of the twentieth century. [Steward, 1938:185]

Paiutes: Amargosa: Pahrump: fall festival: pinyon nuts - Four villages celebrated fall festival together at Pahrump (Pahrump, Yaga, Mogua, and Nogwa), and they all harvested pinyon together in the Spring Mountains. [Lingenfelter, 1986:22]

Paiutes: Amargosa: Pahrump: Chief Tecopa - Tecopa of Pahrump was pakwinavi of all four villages (Pahrump, Yaga, Mogua, and Nogwa) in the latter hatf of the nineteenth century. [Lingenfelter, 1986:22]

Paiutes: Pahrump: pinyon nuts: hunting - Pahrump Paiutes hunted as far as the Shoshone Mountains. Ash Meadows Shoshones were often invited to harvest on the Spring Mountains, and when pinyon nut crops failed in the Spring Mountains, Paiutes were invited to harvest in the Shoshone Mountains. [Steward, 1938:183]

- Paiutes and Shoshones: Ash Meadows: pinyon nuts - Ash Meadows people gathered pinyon nuts in the Spring Mountains together with Southern Paiutes from villages farther south. [Lingenfelter, 1986:21]

- Paiutes: Ash Meadows: Oasis Valley: wild plant harvesting - Ash Meadows people harvested sand bunch grass seeds at Big Dune, just south of Yucca Mountain. There they sometimes met Shoshone people from Beatty. [Steward, 1938:183]

- Paiutes: Shoshones: Owens Valley: mixed population - Steward reports that, in aboriginal times, Fish Lake Valley in the Owens Valley area had a mixed population of Paiutes and Shoshones. [Steward, 1938:58-59,62-65]

Shoshones and Paiutes: Belted Range: Spring Mountains: intermarriage of Shoshone and Paiutes: Panamint Joe Stuart - Panamint Joe Stuart was from the Belted Range. He married a Paiute woman from the Charleston Mountains (in the Spring Mountains). [Steward, 1938:95]

Native Americans: Oasis Valley: Death Valley: Southern Nevada: territories: kinship ties - Families from Fish Lake Valley, Lida, and northern Death Valley were connected by marriage and bloodlines to families from Beatty, Furnace Creek, Saline Valley, Darwin, and other areas of the Panamint Mountains. "Home generally referred to the large area used by a family as the home range; the place of an individual's birth was a specific location within that range...These ranges can be traced back through time for at least three generations." Among examples of home ranges for specific families is that of the Stewart family from Beatty. They "traveled to the east into the Belted Mountains, west into Death Valley, and north to Lida." [Sennett-Walker, 1987:82-83] 
Native Americans: Oasis Valley: Amargosa River: intermarriage of Native Americans and Euroamericans - "Long prior to the discoveries of ore at Tonopah and Goldfield the springs in Oasis Valley, just north of the site of Beatty, proved attractive to a few desert wanderers who took Indian wives and established rude ranches along the Amargosa River, the only stream of drinkable water within a radius of 40 miles." [Ransome, 1907:41]

Paiutes: Pahrump: camp: farm labor - George T. Childers, grandson of Joseph Yount (first owner of the Manse Ranch) spent his youth at Pahrump. He noted that a "Piute squaw" served as the doctor at his birth in Tecopa in 1878 and that "Piutes, who lived on the slope above our adobe house, did all the work on the farm." "I still speak Piute [noted Childers] as I had no white playmates." ["Early History of Pahrump, Death Valley Told in Letter," Goldfield News and Beatty Bulletin, vol. 47, no. 1, June 24, 1949, p. 1, col. 4]

Paiutes: Pahrump: Native American prospecting: Chief Tecopa - Chief Tecopa of Pahrump agreed to show George Montgomery gold ore in the mountains near Pahrump in exchange for a new suit of clothes every year. [Cook, nd:24]

Native Americans: Ash Meadows: Pahrump: political leadership: Chief Tecopa Steward's interviewee "AH" of Ash Meadows named 'Tacopa' as the chief for the region of Ash Meadows and Pahrump. [Steward, 1938:185]

Paiutes: Ash Meadows: intermarriage of Native Americans and Euroamericans: Black family - Jack Longstreet's common law wife from the early 1900 s until his death was a Paiute woman, Fannie Black Longstreet, of the Black family from Ash Meadows. Fannie's sister was the wife of Albert Howell. As of about 1906, Fannie Black was living with a gambler in Rhyolite. After being beaten by the man, Fannie sought protection from Longstreet who was in Rhyolite at the time, indicating that the two at least knew each other at that time. There was a confrontation between the gambler and Longstreet, and Fannie lived with Longstreet from that time on. [Zanjani, 1988:109-111]

Paiutes: Ash Meadows: Native American prospecting: Black family - Bob Black accompanied Walter Scott (Death Valley Scotty) on several prospecting trips. Black located some "rich float while hunting mountain sheep in the Avawatz Mountains." Scott and Black made several attempts to locate the ledge where Black had found a chunk of nearty pure gold. [Zanjani, 1988:116-117]

Ash Meadows: outlaws - In the late 1800s, "Ash Meadows was a favorite stopping place for travelers on the way to Calitomia, as well as a notorious hideout for outlaws." [Lewis, 1969:5]

Ash Meadows: outlaws - Zanjani noted that Ash Meadows was frequented by outlaws and desperadoes in the late 1800 s and early 1900 s. Many murders were committed in the Ash Meadows region, but the area was largely outside the sphere of effective law enforcement. [Zanjani, 1988:112-114]

Native Americans: Ash Meadows: mine workers - "[T]he borax works east of Death Valley employed indian men from Ash Meadows." [Sennett-Walker, 1987:83] 
Native Americans: Whiterock Spring. rock shelter: Captain Jack - A 1948 archaeological survey team examined a rock shelter north of Whiterock Spring, believed to have been occupied by Captain Jack in the late 1800s and early 1900s. The guide of the survey first saw the rock shelter in 1931. At that time, it contained a wide array of industrially produced household goods. In 1948, a hammered brass bracelet "of the type popular with Indian women during the 1850 s and 1860 s" was $^{\text {" w }}$ found, as well as several mealing stones and a variety of rusted metal items. Captain Jack is said to have been a "Paiute renegade Indian who left his tribe and hid out in the hills, making his headquarters in this open faced rock shelter... From this place he is alleged to have raided an emigrant train and returned again with his loot. He had a small band of outlaws with him and was ultimately outfoxed by the United States cavalry. All of his band except himself and two others were killed. Captain Jack and his two henchmen fled to Mexico (so it is said). Later, Captain Jack returned to Nevada. He died at his cave about 1928." ["Archeologist and Party in Survey of 40-Mile Country," Goldfield News and Beatty Bulletin, vol. 44, no. 50, April 23, 1948, p. 2, col. 5]

Native Americans: Rhyolite: camp - A postcard published by A.E. Holt is titled "Indians Gambling-A Bunch of Piutes in Camp at Rhyolite, Nevada," circa 1910. [A.E. Holt album, Photo Collection, Nevada Historical Society]

Native Americans: Beatty - A photo shows three Native American women and a Native American girl and is inscribed "Indians near Beatty," circa 1910. [Indian Photograph \#555, Ethnic File, Nevada Historical Society]

Native Americans: Beatty - A photo of a Native American man, woman, and child, inscribed "Indians in Beatty," no date. [Ethnic File, Photo Collection, Nevada Historical Society]

Shoshones: Rhyolite - A photo of three men captioned "Pete Busch with Young Joe and Panamint Joe, Chief of Rhyolite Shoshone Indians." [Ritter, 1982: np]

Native Americans: Rhyolite: entertainment - In the boom years of Rhyolite, a Sells Floto circus performed. "Rhyolite tumed out en masse," including "Indians from miles away." [Ritter, 1982:6]

Native Americans: Oasis Valley: Panamint: Death Valley: intermarriage and kinship ties - Native Americans interviewed by Beth Sennett-Walker indicated that "families from the northern areas, Fish Lake Valley, Lida, and northern Death Valley, were connected by marriage and blood lines to families from Beatty, Furnace Creek, Saline Valley Darwin, and other areas of the Panamint Mountains. ' $[\mathrm{H}] \mathrm{ome}$ ' generally referred to the large area used by a family as the home range; the place of an individual's birth was a specific location within that range.... These ranges can be traced back through time for at least three generations." [Sennett-Walker, 1987:82]

Native Americans: Timber Mountain: pinyon nut harvesting - Worman examined what he identified as a Paiute pinyon nut cache on Timber Mountain. The cache included a tin pan, documenting that the cache dated to the post-contact period. [Worman, 1969:29] 
Pahrump: towns: Native American employment - The town of Sandy was located in Pahrump Valley and had a post office from 1896 to 1910, at which time the name was changed to Ripley. Sam Yount, son of Joseph Yount, ran a store and post office there. "There was an Indian mail carrier." [Boyer, nd:67,72; Carison, 1974:209]

Paiutes: Pahrump area: Native American leadership: interactions between Native Americans and Euroamericans: Indian runners - "Years before this incident [in 1904] Tecopa had sent word by runners to the miners in Calico of an intended raid on them by some renegade Indians. miners were so grateful to him for saving their lives that they asked him what he would like as a gift. He said he wanted a high silk hat and a red blanket. So, thereafter, as long as he lived, the miners in Calico kept him supplied with a silk hat and a red blanket." [Boyer, nd:77]

Paiutes: Timpahute area: hostilities between Native Americans and Euroamericans - Two Native Americans, Tempiute Bill and Moquitch, were suspected of killing a man at Crescent. Hearing this, the two fled, but were apprehended by officers. They were then lynched by vigilantes. Hostilities between Native Americans and Euroamericans in the area flared after the lynching. Six miles east of Hiko, Native Americans attacked three easterners walking the Emigrant Trail to California, killing two of them. Euroamericans organized to hunt down Native Americans in response, capturing and hanging the two Native American men believed responsible for the attack and attacking "two of the main Indian camps in daybreak raids. At the largest, on the site of Pahranagat's present community center, seventeen Indians were killed. About the same number were slaughtered at another camp further up, probably around Crystal Springs." [Ashbaugh, 1963:78-79]

Jack Longstreet: relations between Native Americans and Euroamericans Longstreet "spoke fluent Paiute, was regarded as a leader among the Indians, and his role as mediator for Indian rights in the white world was the one that historians have found frontiersmen married to Indian women typically played. Indian agency officials tended to regard these men as troublemakers, but it is also possible to see them as champions of Indian rights." [Zanjani, 1987:45]

Native Americans: Death Valley: mineral resources - Raiph "Dad" Fairbanks "was browsing around out back of Shoshone one day and went into the Indian camp. There I found an Indian woman, Panamint Tom's squaw, washing her hair. She was doing it in an old gold pan full of something that looked like a mixture of mud and water and about the thickness of buttermilk. I watched her, and when she'd finished the job her hair was soft and clean and glossy. I asked where she got the stuff and she pointed out a certain hill. I immediately went to the hill, found a veritable mountain of valuable filtering clay, and staked out my claim to it. When I first started prospecting, this claim wouldn't have been worth a thin dime. But the change from oats to gasoline had made a big difference. I knew that this clay was extensively used in the refinement of petroleum and that, up to the time of my finding the deposit, the entire supply used in this country had been imported." Fairbanks sold the claim to the Shell Oil Company. [Lisle, 1974]

Native Americans: southern Nye County: disease and population decline - From 1890 to 1905, roughly two-thirds of the Native American population in southern Nye County died from "sickness of body and spirit that the census taker ascribed to the white man's whiskey and his love." [Zanjani, 1988:111] 
Paiutes: Owens Valley: fandangos - The locations for fandangos were at Bishop, Big Pine/Independence, Benton, Oasis, and Mono Lake. Western Mono and Miwok people sometimes attended. [Steward, 1933:321]

Paiutes: Owens Valley: population - Aboriginal population in Owens Valley was estimated at between 1,700 and 2,000. [Liljeblad and Fowler, 1971:415]

Paiutes: Owens Valley: population - Aboriginal population in Owens Valley was estimated at over 2,000. [Wilke and Lawton, 1976:46]

Rhyolite: population - The peak population of Rhyolite during the decade 19001910 was estimated at over 10,000. [Weight and Weight, 1985:26]

Fortymile Canyon: stage road - In the early mining days, a road was cut through Fortymile Canyon to Tippipah. [Koenig, 1984:72]

Fortymile Canyon: stage routes - During the period 1870-1900, there were freight and mail routes through the Nevada Test Site, specifically through Fortymile Canyon. [Pippin and Zerga, 1983:57]

Fortymile Canyon: stage road - The Emigrant Trail was used as a part of the mail and freight route between Salt Lake and Los Angeles, with relay stations at Whiterock Spring, Tippipah Spring, Fortymile Canyon, and Ash Meadows. [NTS News, vol. 12, no. 6, August 8, 1969, p.7]

Fortymile Canyon: mining activities - It is reported that a lead-silver mine was worked in Fortymile Canyon in about the 1880s. In 1905, the old mine was rediscovered and worked again. Mr. Doser, one of the owners, brought some of the old tools into Beatty from the mine. "A certain party in Beatty, while a resident of Eureka, Nevada, over twenty years ago [sometime before 1885] remember (sic) an outfit of Mexicans that made irregular trips into this country and returned with a string of animals loaded with silver ore identical in appearance with that of the old mine in Forty Mile. This party is of the opinion that they mined their ore at this place, transported it on mule back over 200 miles, and made a good profit. A quantity of selected and sorted material was mined and put aside for another trip but for some reason was never removed." ["The Old Lead-Silver Mine of Forty Mile," Beatty Bullfrog Miner, vol. 2, no. 47, February 23, 1907, p. 2, col. 2]

Oasis Valley area: Fortymile Canyon: mining activities - "[A] generation before the discovery of Tonopah and Goldfield, persons unknown, presumably mexicans, mined ore at a number of points in the eastern portion of Bullfrog district....Proof...is had in the decaying rock heaps and chimneys between Beatty and Gold Center, and in the slag and quantities of copper-lead ore scattered about the 'ancient reduction works'....M.M. Beatty, who resided near this town of his name for ten years, told a Miner representative this week that prospectors, before Bullirog was thought of, discovered another arastra three miles east of Beatty Other old mines, worked by people and at times unknown, have been stumbled upon by latter day prospectors and promptly located...Messrs Doser and Llewellyn of Beatty own a valuable piece of property in Forty Mile canyon... which was worked in the past by Mexicans." ["The Old Mines of the District," Beatty Bullfrog Miner, vol. 2, no. 51, March 9, 1907, p. 9, col. 1]

- Cane Spring: stage road - Cane Spring has structures used for a stop on the freight road between Utah and San Bernardino before 1900. [Worman, 1969:12-15] 
Beatty area: trails - A historic trail follows Yucca Wash until it crosses a low pass east of Chocolate Mountain into Beatty Wash, probably dating to early twentieth century prospecting. [Pippin, Clerico, and Reno, 1982:77]

Oasis Valley area: mining activities - Many years before the mining boom around Oasis Valley in the first decade of the twentieth century, there was a Mexican mine in the Bullirog area, a few miles southwest of Beatty. The miners left a shaft 100 teet deep, a stone house, and a corral. [Tonopah Miner, vol. IV, no. 16, September 30, 1905, p. 1]

- Bare Mountain: mining activities - There were gold-producing Mexican claims on Bare Mountain about 12 miles southeast of Beatty. [Cornwall, 1972:3-6]

- Wahmonie: mining activities - The Hornsilver mine in the vicinity of Cane Spring dates prior to 1905. [Kral, 1951:206]

Calico Hills: mining activities - The Quartz Gold Company mining operations were located in the Calico Hills, just south of Shoshone Mountain and east of Fortymile Canyon. [Myrick, 1963:494]

- Wahmonie district: mining activities - In addition to the Hornsilver mine, there were two travertine quarrying operations in the southern portion of the Specter Range and a copper prospect known as the Lucky group in the Striped Hills (both areas south of Skull Mountain). [Kral, 1951:207]

- Panamint Valley: Owens Valley: mining activities - In the early 1900s, the mining industry revived in the Panamint and Owens Valley regions. [Greene, 1981:23]

Chemehuevi: Charleston Mountain: hunting territories - Van Valkenberg's

Chemehuevi informants indicated that Chemehuevi families had hereditary rights to hunting territories and pinyon nut gathering territories on Charleston Mountain. The informants also referred to Chief Tecopa as one of the last two chiefs. [Van Valkenberg, 1976:13]

- Paiutes: Owens Valley: agriculture - The two principal plants produced in the irrigated fields were apparently the wild-hyacinth (Dichelostemma pulchella) and the yellow nut-grass (Cyperus esculentus). Other plants that also benefited from irrigation apparently included love grass, wheat grass, wild rye, and sunflower. [Wilke and Lawton, 1986:47; Lawton et al., 1976]

\section{Post-Contact Period To 1900}

$1820 \mathrm{~s}$

1826 Paiutes: Santa Clara River: agriculture - Jedediah Smith saw 15 to 20 Indian people as he scouted far ahead of his party along the Santa Clara River. After rejoining his party and returning to the spot chosen for a camp. Smith and his group saw 20 or 30 Indian people there. Smith eventually persuaded one Indian to approach him, and then "10 or 12 of them came bringing in their hands an ear of corn as an emblem of peace...As provisions was our greatest present desire we were much pleased to hear that they had corn and pumpkins close at hand. The Indian people brought quantities of corn and pumpkins." Smith traded various 
goods for a supply of corn. Two days later he reported: "I visited some Indian lodges a mile above our camp on the creek for the purpose of seeing how they farm. Their little corn patch is close on the bank of the creek for the convenience of water. The Creek is dammed about and the water is conducted in a trunk to a place where it can be spread over the surface. For a hoe they use a piece of wood 3 in broad and 4 feet long." Smith also recorded farms of corn, pumpkins, and squash at the Muddy River. [Smith, 1977:57-59,64]

1827 Paiutes: Santa Clara River: agriculture - Jedediah Smith led a party of trappers through the Rockies, Utah, and southern Nevada on the way to California. Smith's joumal records that they encountered a "nation" of "Pa-Ulches" raising corn and pumpkins along "Com Creek," the Santa Clara fork of the Virgin River. [Hafen and Hafen, vol. 1, 1954:115]

1827 Native Americans: Santa Clara River - When Jedediah Smith revisited the Santa Clara River where he had observed Indian farms and traded for corn and squash, he found the site deserted: "Not an Indian was to be seen, neither was there any appearance of their (sic) having been there in the course of the summer their little Lodges were bumed down." [Smith, 1977:58]

1829 Old Spanish Trail: Santa Clara River: trappers - A party of trappers including Pegleg Smith (Thomas L. Smith) trapped along the Santa Clara and Rio Virgin rivers. Two of the men then transported the skins to Los Angeles, but there is no information about the route they took. [Hafen and Hafen, vol. 1, 1954:136]

\section{$1830 \mathrm{~s}$}

1829-30 Amargosa River: Spring Mountains: trade - A livestock trading expedition traveled from New Mexico to Califomia, under the leadership of "commandant" Antonio Armijo, who kept a diary. The party crossed southem Nevada from Las Vegas to the Spring Mountains, and traveled along the Amargosa River to Resting Springs. [Hafen and Hafen, vol. 1, 1954:159; Hafen and Hafen, vol. 2, 1954:18-9]

1830 Native Americans: Amargosa Valley - On January 7, Rafael Rivera, a scout with the Antonio Armijo party, returned to the party's main camp at the mouth of Las Vegas Wash and reported he had found an Indian village on the Amargosa River. [Hafen and Hafen, vol. 1, 1954:167]

1830 Paiutes: Amargosa Valley: village: interaction between Native Americans and Euroamericans - Antonio Armijo's pack train traveled from the Las Vegas Wash southwestward across the Nevada desert. On January 14, it arrived at the Amargosa River, which Armijo's diary refers to as the "River of the Payuches." The diary states that there was a peaceful encounter between the travelers and the residents of a Paiute village. Armijo's diary entry reads: "At the River of the Payuches, where a village was found: nothing happened for it was gentle." [Hafen and Hafen, vol. 1, 1954:164,167]

1830 Amargosa Valley: Old Spanish Trail: trade - A trading party led by William Wolfskill and George C. Yount was the first recorded party to follow the route later known as the Old Spanish Trail on a journey from New Mexico to California. [Hafen and Hafen, vol. 2, 1954:19] 
1830s Old Spanish Trail: trade - From 1830 on, there was regular traffic along the Old Spanish Trail, conveying woolen blankets westward in the fall, and driving herds of horses and mules eastward in the spring. The Old Spanish Trail had become "an established, well-worn route long before the Mormons came to settle in the Great Basin in 1847." [Hafen and Hafen, vol. 2, 1954:19-21]

1830s Paiutes: Old Spanish Trail: Native American slave raids - American Indians of the southern Nevada deserts were among those captured by slave traders for sale in New Mexico. Paiutes of the Nevada deserts were often raided by other Native American ethnic groups and their children were then traded into slavery. [Hafen and Hafen, vol. 2, 1954:21,261-2]

1830s Paiutes: Amargosa/Death Valley - The largest American Indian village in the area was at Yaga (now Tecopa Hot Springs) with about 70 residents, seen by Euroamericans in 1830. [Lingenfelter, 1986:21]

1834 Owens Valley: Euroamericans: trappers - Joseph Reddeford Walker made several traverses of the Owens Valley in the 1830s and 1840s, the first apparently a beaver-hunting expedition, which he led in 1834. [Wilke and Lawton, 1986:9]

\section{0-48}

1844 Native Americans: Resting Springs: hostilities between Native Americans and Euroamericans - Mexican livestock traders with a herd of some thirty horses were attacked by a band of some 100 Native Americans while camping at Resting Springs. Two men survived, and joined the Fremont party when it passed through the area shortly thereafter. [Hafen and Hafen, vol. 1, 1954:289; Fremont, 1845:261]

1844. Amargosa Valley: Fremont expedition - John C. Fremont was the first official American explorer to travel a substantial portion of the Old Spanish Trail, traveling from west to east and passing through the Amargosa Valley, Resting Springs, Pahrump Valley, and Mountain Spring in the Charleston Mountains. [Hafen and Hafen, vol. 1, 1954:286-298]

1844 Amargosa Valley: Fremont expedition: hostilities between Native Americans and Euroamericans - In late April 1844, the Fremont expedition reached Agua de Tomaso (Bitter Springs). There Kit Carson and another scout went to track down the horses stolen from the party of Mexicans whose survivors had joined the Fremont expedition, and to find the Indians who were responsible. They found the horses some fifty miles from Bitter Springs; they killed two Indians, returning with their scalps. [Hafen and Hafen, vol. 1, 1954:290; Fremont, 1845:262]

1844 Amargosa Valley: Fremont expedition - On about April 28, the Fremont expedition reached the Amargosa River. On April 29, the party reached Archilette (or Resting Springs) and found the corpses of two men who had been driving the herd of horses that had been attacked a few days earlier. [Fremont, 1845:264-5]

1844 Pahrump: Spring Mountains: village: Fremont expedition - On April 30 and May 1, the Fremont expedition traversed Pahrump Valley. On May 1, the expedition ascended the slope to Mountain Spring in the Spring Mountains. Fremont describes his campsite as "the site of an old village." [Fremont, 1845:265; Hafen and Hafen, vol. 1, 1954:685] 
1844 Virgin River: Fremont expedition: interaction between Native Americans and Euroamericans - On the Rio de Los Angeles branch of the Rio Virgin, "Indians crowded numerously around us in the morning...Several times during the day the camp was insulted by the Indians...Some of the Indians were on the bottoms, and others haranguing us from the bluffs; and they were scattered in every direction over the hills...A man who appeared to be a chief, with two or three others, forced himself into camp...In the evening I gave a fatigued horse to some of the Indians for a feast; and the village which carried him off refused to share with the others, who made loud complaints from the rocks of the partial distribution...During the day they occasionally roasted and ate lizards at our fires..." Along the Rio Virgin, "Indians appeared in bands on the hills, but did not come into camp...For several days we continued our journey up the river...the sandy soil was absolutely covered with the tracks of Diggers, who followed us stealthily." [Fremont, 1845:267-268]

1844 Virgin River: Fremont expedition: interactions between Native Americans and Euroamericans - American Indians killed a mule and one of Fremont's "best men" along the Virgin River. Along the Santa Clara River, Fremont's party was "constantly dogged by bands, and even whole tribes of...marauders." [Fremont, 1845:269]

1847 Cane Spring: early Euroamerican presence - At Cane Spring, there is a rock inscribed "F.O. Byor 1847." [Nusbaumer, 1967:39]

1849

1849 Utes: Utah: forty-niner emigrants - William L. Manly encountered Chief Walker on the Green River. Using sign language and drawing a map. Walker gave Manly advice and directions on routes through Utah and beyond and information on areas with hostile Indians to be avoided. [Manly, 1928:111-114]

1849 Utah: forty-niner emigrants - In Fall 1849, between 300 and 500 people and at least 500 oxen and cattle left the Salt Lake area to pursue a southern route to California. About 100 persons followed various routes through southwestern Nevada, including the study area, and on through Death Valley. These groups included what have come to be referred to as "the Jayhawkers, the Bennett-Arcane group, the Brier party and an assortment of independents. There were also subdivisions such as the Mississippians, the Georgians, and [the] Town-Martin 'messes." "The Death Valleyites, about a hundred in all, left Mt. Misery relatively united. But gradually the unity disintegrated. Within the present Atomic Energy Commission test site in Nevada, the Jayhawkers, Briers, and independents veered westward on separate courses. The Bennetts and Arcanes, with Nusbaumer's small group, circled southward. In all, eighty-four men, three women, and eight children are believed to have crossed the wastelands of Nevada into the valley of death..." [Nusbaumer, 1967:3-4,6]

1849 Forty-niner emigrants: livestock: study area - The party of forty-niner emigrants that broke into smaller units and took various routes through the study area and vicinity, including Fortymile Canyon, included about 500 horses and cattle when it left the Salt Lake area. [Manly, 1928:124]

1849 Desert Valley: forty-niner emigrants: interactions between Native Americans and Euroamericans - In Desert Valley, west of the Pahranagat Mountains, Native Americans stole two horses, according to the account of one of the Briers. [Long, 1941:169] 
1849 Paiutes: Tempiute area: Manly-Rogers party: interactions between Native Americans and Euroamericans - At "Sand Spring" near Tempiute, the ManlyRogers party captured two Native American men who guided them to another water source ten miles to the southwest, covered by a "great flat rock." [Nusbaumer, 1967:36]

1849 Paiutes: Tempiute area: Manly-Rogers party: interactions between Native Americans and Euroamericans - Sheldon Young's diary reports: "This day lay in camp. Caught two Pi Ute Indians. Found that we were too far North, let one of them go again and kept the other for a guide. Caught another in the evening." [Long, 1941:256]

1849 Native Americans: Groom district: forty-niner emigrants - According to the account of the younger Brier, atter their party had passed Groom Lake and reached "the mouth of a deep walled fissure....A German....surprised two scantily-clad savages who were engaged in lading the sand out of a slow-pulsing spring. Seizing the terrified natives, he led them into camp... Comprehending, at length, that water was the pressing want, they pointed toward a mountain whose base-line marked the confines of the desert. One of them was chosen for a guide, and a party of young men, supplied with canteens, was immediately dispatched to the distant spring. Clear and cold, it rose in its rocky vase, and was found carefully covered by a great, flat rock. The swarthy captive, having quieted suspicion by his willing and faithful service, struck the trail back with a rapid pace, and when advancing night made objects indistinct, he eluded vision at a bound, leaving the panting white men to find their way home....The native held in camp had been the beneficiary of many gitts, but he, too, managed to elude his sleepy guards" (Brier in "Argonauts of Death Valley," Grizzly Bear, June 1911, p. 2, col. 3, reprinted in Long, 1941: 173). Long concludes that the first spring in this account was either Cottontail Spring or Tub Spring, and that the second spring was Whiterock Spring, "the largest and most permanent spring in Emigrant Valley, even before cattlemen enlarged it." [Long, 1941:174-176]

1849 Native Americans: study area: interactions between Native Americans and Euroamericans: Manly-Rogers party - Sheldon Young's diary reports that somewhere between Whiterock Spring and the Amargosa Valley, along a southwesterly course, the party "[h]ad one ox driven off by the Paiutes last night." [Long, $1941: 256]$

1849 Fortymile Canyon: forty-niner emigrants - "A small group, the Briers among them, kept west into Forty Mile Canyon" after reaching Emigrant Canyon. "The Briers were compelled to abandon their wagons soon after entering Forty Mile Canyon" and "the Briers entered Amargosa Valley from Forty Mile Canyon." [Long, $1941: 170,179,182,185]$

1849 Native American agriculture: food caches: Manly-Rogers party - Along its route through southeastern Nevada, the Manly-Rogers party found Native American cornfields at some springs, as well as large piles of bunch grass stored for food at Native American camps. [Manly, 1928:134]

1849 Native Americans: water resources: Manly-Rogers party - Along its route through southeastern Nevada, the Manly-Rogers party found an American Indian camp with a well carved out of stone and covered with large stone. The well was full of water. [Manly, 1928:134-5] 
1849 Native Americans: Manly-Rogers party - Along its route, the Manly-Rogers party was followed by a small party of Native Americans. [Manly, 1928:135]

1849 Native Americans: water sources: captive: Manly-Rogers party - Members of the Manly-Rogers party captured a Native American who had attempted to hide in a cave, near a small rock basin of water which the travelers had just drained dry. The Native American captive led the party to two more water holes several miles distant, before managing to escape. [Manly, 1928:137]

1849 Native Americans: Manly-Rogers party - A Native American woman, infant, and small child fled from an Indian camp at the approach of the Manly-Rogers party. [Manly, 1928:139]

1849 Native Americans: Manly-Rogers party - "We saw signs of Indians almost every day." [Manly, 1928:140]

1849 Native American: food caches: Manly-Rogers party - The Manly-Rogers party found Native American food caches in rock shelters on a high cliff containing "balls of a glistening substance, looking something like pieces of variegated candy stuck together...as large as small pumpkins...sweet but sickish." The travelers consumed them. [Manly, 1928:148]

1849 Native Americans: Cane Spring: agriculture: Manly-Rogers party - The ManlyRogers party found an "Indian farm" at Cane Spring. They saw a cornfield with the stalks remaining after harvest. [Koenig, 1984:86-93]

1849 Native Americans: Cane Spring: agriculture: Manly-Rogers party - The ManlyRogers party stayed for nine days at a "hastily abandoned" Native American village, "most likely Hugwap at Cane Spring...devouring the winter's store of squash which they found there and fattening their oxen on the stubble in the cornfield." [Lingenfelter, 1986:42]

1849 Native Americans: Cane Spring: agriculture: Manly-Rogers party - Manly-Rogers managed to steal up on a Native American camp before the occupants could flee. A Native American man went into the dwelling and brought out a "handful of corn" to give to them. Nearby there were warm springs and a cornfield with dry stalks still standing. Manly signed that he would return the next day and took water from the springs to take back to the wagon train. [Manly, 1928:151]

1849 Native Americans: Cane Spring: agriculture: Manly-Rogers party - Nusbaumer dated the discovery of the Indian farm as December 8. [Nusbaumer, 1967:38]

1849 Cane Spring: livestock grazing: Manly-Rogers party - The Manly-Rogers party traveled to the warm spring found the previous day. "The warm spring was quite large and ran a hundred yards or more before the water sank down into the...desert. The dry cornstalks of last year's crop, some small willows, sagebrush, weeds, and grass suited our animals very well, and they ate better than for a long time, and we thought it best to remain two or three days... The Indian we had left here [and other members of his family] had gone, leaving behind nothing but a chunk of crystallized rock salt. He seemed to be afraid of his friends." [At this point the Manly party consisted of seven wagons with at least seven teams of draft animals plus other animals.] [Manly, 1928:153,157] 
1849 Cane Spring: Manly-Rogers party - The Manly-Rogers party arrived at Cane Spring on December 9 and stayed until the 19th. According to Nusbaumer's diary entry for December 19: "Today we left the farm where we had been camping for nine days and started for a spring which was said to be situated about seven miles from here." [Nusbaumer, 1967:38,40,42]

1849 Native Americans: Cane Spring: agriculture: Manly-Rogers party - While Manly and Rogers were away scouting for three days, the Manly party remained at the warm springs and found a cache of squashes "sufficient in number so that every person could have one." [Manly, 1928:156]

1849 Native Americans: Cane Spring: agriculture: Manly-Rogers party - John Rogers' account states that "[w]e struck an Indian rancheria. The Indians were very much frightened. They had a garden and raised corn and squashes. Our train being behind we told the Indians that we had to go back... The next morning we hitched up and drove to the rancheria. All had left when we got there. Being good feed and water we camped there eight days. During that time we eat a good many of those squashes." [Merced Star, April 26, 1894, reprinted in Belden, 1954:64]

1849 Native Americans: Cane Spring: agriculture: Manly-Rogers party - Manly reported that "my companions told me that after I had left [the Indian rancheria] they had found a small pile of squashes covered over with sage brush. They had divided them in camp and all were eaten with a relish as they were very good." [Santa Clara Valley, vol. V, no. 1, p. 10, reprinted in Johnson and Johnson, 1987:59]

1849 Native Americans: Cane Spring: agriculture - Koenig, in reconstructing the location of the Native American and rancheria farm where the Manly-Rogers party stopped, concluded that "[a]ny reasonable evaluation of the distance and directions [given in Nusbaumer's joumal] precludes the 'farm' as being farther south of Cane Springs, for example at present-day Indian Springs, which would place them too far southwest for any feasible route into Furnace Creek Wash." [Nusbaumer, 1967:43]

1849 Death Valley area: interactions between Native Americans and Euroamericans: Manly-Rogers party - Rogers reported that after leaving the rancheria (at Cane Spring) and traveling southwestward for two days, members of the party went to round up the cattle in the moming and "found three of them shot with arrows, two of them with only one arrow in each, and the third...filled with them. We killed and skinned him and jerked the meat. ...We had never stood guard since the train had busted up. I suppose the Indians shot our cattle out of revenge for eating their squashes." [Merced Star, April 26, 1894, reprinted in Belden, 1954:64)

1849 Death Valley area: Manly-Rogers party: interactions between Native Americans and Euroamericans - While the Manly-Rogers party was camped two days travel westward from the Native American rancheria, "three of the oxen had been shot with arrows by the Indians. One was shot fatally and we killed the poor beast and ate his flesh. The other two got well. I told the men they were now getting their pay for stealing their squashes and might possibly fare worse. I think the object of the Indians was to cripple our cattle so that we would leave them, they would then use it for food." [Santa Clara Valley, March 1888, vol. V, no. 1, p. 10, reprinted in Johnson and Johnson, 1987:61] 
1849 Native Americans: Cane Spring: agriculture: forty-niner emigrants - Nusbaumer, traveling with Manly, reported that "[t]oday we left the farm where we had been camping for nine days" (a farm most sources conclude must have been located at Cane Spring). The group started for a spring which was said to be situated about seven miles from the farm. [Nusbaumer, 1967:40]

1849 Native Americans: water sources: Manly-Rogers party - Manly found that at a seep in a small canyon "the Indians had made a clay bowl and fastened it to the [canyon] wall so that it would collect and retain about a quart of water." [Manly, 1928:160]

1849 Native American camp: Manly party - Manly found a cave "which had the appearance of being continuously occupied by Indians." Nearby he found a very old and apparently crippled inan concealed in a "well-like" hole dug in a small sand hill. [Manly, 1928:163]

1849 Native Americans: Ash Meadows: interactions between Native Americans and Euroamericans: Ash Meadows Charley - Zanjani states that "[a]ccording to Ash Meadows Charlie, who still was war chief of the Ash Meadows Indians in Longstreet's day [late 1800s, early 1900s], the angry Indians attacked the [fortyniner] emigrants as they camped at Longstreet Springs, shooting their oxen with arrows. News of their ordeal forestalled future attempts to use this route and left Ash Meadows securely isolated in the desert." [Zanjani, 1988:62]

1849 Ash Meadows: Manly-Rogers party - Nusbaumer's diary describes a spring in a cave that corresponds to Devil's Hole west of the Ash Meadows area. [Nusbaumer, 1967:43]

1849 Native Americans: Death Valley area: Native American camp - John Rogers' account states that, "at the mouth of the creek where it emptied out into the plains," he and Manly "found a big Indian camp [at the mouth of Fumace Creek Wash]. Their fires were still burning and the Indians gone, except an old man who was blind. He was crawling around on the ground. He had a little willow basket full of muddy water and had a sharp stick which he was using in digging up roots." Manly and Rogers scouted ahead another ten miles. "When we struck the Indian camp again the old Indian was gone. I think that he was lett there for a purposeto see what we would do with him. I think the kind treatment we gave that Indian [Rogers gave him meat and water] saved our party." [Merced Star, April 26, 1894, reprinted in Johnson and Johnson, 1987:150-151]

1849 Death Valley region: forty-niner emigrants: interactions between Native Americans and Euroamericans - Hungry Bill, who died in the 1930s, was a boy of about 12 in 1849 and was the grandson of the old American Indian man who Manly and Rogers encountered in the otherwise empty Indian village. [Long, 1941:188]

1849 Fortymile Canyon: forty-niner emigrants - Samuel Davis in his History of Nevada reports "a tradition among the miners of Pahranagat that some of the forty-niners passed through Fortymile Canyon...based on the fact that, during the mining boom of 1865 and 1866, tires and other irons, such as were used on emigrant wagons, were found in that canyon, taken to Pahranagat, and again used by the miners." "Grant Welch, of Sharp, Nevada, has found irons of emigrant wagons in Forty Mile Canyon about six miles from Tippipah Spring." [Long, 1941:101] 
1849 Fortymile Canyon: forty-niner emigrants - "Mrs. Brier [one of the 49er emigrants] speaks of entering 'a branch of Forty Mile Canyon'...it is probable that the irons Mr. Welch found...belonged to the Brier wagons, and that the Briers entered Forty Mile Canyon from Tipipah Springs." [Long, 1941:102]

1849 Death Valley Junction: forty-niner emigrants: interactions between Native Americans and Euroamericans - "The Indians, doubtless in reprisal [for the emigrants' taking supplies of food stored by the Indians near Cane Spring] attacked one division of the emigrant train near what is now Death Valley Junction. Wagons were burned, and horses and cattle stampeded.... The tradition of it has been repeated to Dad Fairbanks by the Shoshoni Indians." [Long, 1941:115]

1849 Panamint region: forty-niner emigrants: Native Americans - George Hansen was "one of the Shoshonis to hide in the hills and watch the invasion of Death Valley by the first white men. He was named for Dr. G.S. George, whom he guided to Surprise Canyon in the Panamints during the winter of 1860-61." [Long, 1941:127]

1849 Amargosa: mining activities - The Amargosa Mines, also known as the Salt Spring Gold Mines, were discovered in 1849 and 1850. The 1853 expedition led by Indian Agent E.F. Beale discovered the remains of houses and mining equipment some 15 miles from the Amargosa River. [Hafen and Hafen, vol. 7, 1954:244]

1849 Paiutes: Santa Clara River: agriculture - The diary of Addison Pratt reports that there were fewer Native American cornfields along the Santa Clara River. [Pratt, 1849, in Hafen and Hafen, vol. II, 1954:81]

\section{0-57}

1850- Shoshones: Nye County: employment: ranch workers: teamsters - "[A]s

60 s the better land was acquired by whites, the Shoshones remained and adjusted as best they could. Nearly all became part-time ranch hands and domestics..." [Stewart, 1978:81]

1850s Paiutes and Shoshone: Ash Meadows: villages: Euroamerican settlement - After Euroamerican ranchers moved into the Ash Meadows area, most of the local Paiutes and Shoshones moved to a single ranch of their own at a spring a mile east of Longstreet Spring. [Lingenfelter, 1986:21]

1853 Paiutes: Santa Clara River: agriculture - Gwinn Harris Heap, journalist traveling with an expedition over the Old Spanish Trail led by Lieutenant E.F. Beale, noted that at the Santa Clara River "the Indians being apprehensive that our animals might trespass on their field, which was without enclosure, we permitted them to drive the band several miles up the stream..." [Heap, 1957:234]

1853 Paiutes: Santa Clara River: agriculture - Heap says that in the Virgin River area "[a] Pah-Utah handed me some ears of wheat, the grains of which I preserved, and he stated that it grows spontaneously near the Santa Clara. It is from this stock that the New Mexicans have obtained the seed which they call Payute wheat, and the Mormons, Taos wheat. It has been much improved by cultivation, and is considered the best in New Mexico and Utah." [Heap, 1957:236]

1853 Paiutes: Santa Clara River: slave raids - Heap noted that along the Santa Clara River American Indian women hid their children in fear that white men might carry them off as slaves. [Hafen and Hafen, vol. 1, 1954:278] 
1854 Paiutes: Santa Clara River: slave raids - Sanpitch, a brother of Chief Wakara, went to the Paiutes on the Santa Clara River and bought three young girls to sell as siaves. [Hafen and Hafen, vol. 1, 1954:279]

1854 Amargosa: mining activities - Mormons reportedly discovered and mined a ledge of gold in the Amargosa Valley about 25 miles south of Resting Springs. [Chalfant, 1933:119]

1855 Paiutes: Owens Valley: population - Field notes by A.W. Von Schmidt, part of a surveying party in 1855, estimated a population of about 1,000 "Indians of the Mono tribe" in Owens Valley. [Chalfant, 1933:12]

1855-56 Native Americans: Owens Valley: agriculture - Government survey expeditions under Henry Washington and Von Schmidt explored the entire Owens Valley. Von Schmidt mapped the valley, locating and mapping extensive irrigation systems at some ten locations throughout the northern half. [Lawton et al., 1976:21-27; Wilke and Lawton, 1986:47]

1855 Muddy River: Mormon mission - Mormans established the Las Vegas Mission in 1855 with the intention of converting the Native American people. [Hafner, 1967:11]

1855 Paiutes: slave raids - Utes came to the Muddy River area in December 1855 "buying up squaws and children, and those about here [Las Vegas area] are in great consternation, fearing they will visit here and force them to sell their squaws," according to the report of the Las Vegas Mission. [Jensen, 1926:188]

1855 Paiutes: Las Vegas Mission baptism records - The list of names of American Indians baptized at Las Vegas includes 58 listed as "of the Paiute nation;" 4 "of the Quoeech nation;" and 3 "of the lat nation." [Jensen, 1926:196]

1856 Native Americans: southern Nevada - A diary from the Las Vegas Mission reports "the visit of two strange Indians of the tribe called 'Quoeech,' northwest of Las Vegas in January. They said their home was five days travel from Las Vegas and their country was poor and their people hungry. They also brought word that Sister Nancy, one of those who had been baptized the previous November, was at the point of death. She left Las Vegas January 23 , went fifteen miles, took sick and sent for relatives to come' and see her die.... Her child had died only a month before...[of] erypsipelas of the head and throat." [Squires and Squires, 1955:70]

1856 Paiutes: Muddy River: agriculture - Mormons traveling along the Muddy River "passed the Indian's camp" and noted that "[t]heir corn was just ripening. They all seemed quite friendly and gave us some corn to eat." [Jensen, 1926:242]

1856 Amargosa Valley: mining activities - In 1856, "a gold vein of low-grade ore" was found near the Amargosa River bed. [Spears, 1892:22]

1856 Mormons: Las Vegas Mission: exploration - Bishop Jones reported that he explored the country northwest from Las Vegas, claiming to have "penetrated the country about 400 miles in this direction and found it to be one continuous stretch of dry, burnt-up mountains and arid sand plains, entirely destitute of vegetation or timber....we saw nothing worthy of note except a strata of gold-bearing quartz, about seventy miles north-west from the Vegas. We were gone six days on the trip." The Squires note that Bishop Jones could not possibly have traveled 400 miles to the northwest on a six-day round trip.] [Squires and Squires, 1955:151152] 
1857 Paiutes: Las Vegas region: mineworkers: Native American Indian mineworkers: interactions between Native Americans and Euroamericans - In 1857, Mormons from Las Vegas were mining for lead about thirty miles southwest of Las Vegas. "During the months of August and September we hired the Piedes to pack down the mineral, for which we fed them during the time they were at work and gave them clothes....the Indians threatened us upon every hand. They were stealing from us every chance they could get. Most of the Indians in the country had collected at a spring about 3 hours' travel from us, and were making their calculations to drive off all of our stock and drive us out of the country or kill us. This they had been talking of doing for some time past and I had every reason to believe they would put their threats into execution. The difficulties attending the working of the mines, together with the hostile feelings of the Indians made me not consider it wisdom to remain longer. Accordingly, on the 26th of January, 1857, we left the mines for the Vegas. When we arrived there we sent for the Indian chiefs and had a long talk with them and made them many presents. Theyappeared to feel better for a few days, but in a few days after, one of the chiefs came into the fort and threatened to come upon us and kill us all..." [Jensen, 1926:275-276]

1857 Native Americans: Las Vegas Mission: Native American prospecting: interactions between Native Americans and Euroamericans - Indians told Bishop Jones of the Las Vegas Mission that there was a quantity of lead ore about fifty miles south. Mormons located the ore 27 miles southwest of Vegas. [Squires and Squires, 1955:150-151]

1857 Paiutes: Muddy River: interactions between Native Americans and Euroamericans - Brigham Young sent a wagon train of immigrants to California led by Jacob Hamblin. At the crossing of the Muddy River, the group found Paiutes surrounding another company of wagons and preparing to destroy it. Hamblin gave the American Indians all the loose horses and cattle to dissuade them. Later the same year, Hamblin guided another party, which received news of an impending Indian attack as it approached the Muddy Valley. Hamblin made peace with the Indian people. [Hafner, 1967:10]

1857 Paiutes: Las Vegas and southern Nevada: wild plant harvesting - During the winter, Indian people staying at Las Vegas "seemed to subsist on almost nothing. At that season they lived chiefly on a sweet substance they gathered toward the mountains, which they called chump." [Jensen, 1926:262]

1857 Owens Valley: Euroamerican exploration - Among the whites to enter the Owens Valley in 1857 were Charles Uhl and John Kispert, who returned in 1861 and established a farm. [Chalfant, 1933:123]

1858-59

1858 Owens Valley: mining activities - Several parties of prospectors entered the Owens Valley in 1858. [Wilke and Lawton, 1986:9]

1858 Panamints: mining activities - Mormons reportedly discovered silver ore in the Panamint Mountains and produced some silver bullion in furnaces at Anvil Springs and Furnace Creek. [Chalfant, 1933:119-120] 
1858 Las Vegas Mission: interactions between Native Americans and Euroamericans On June 15, 1858, two Mormon men who were sleeping in their wagons were "awakened by the Indian chief, Patsearump, and a band of his warriors, who asked us if we were their friends; if so, they wanted us to let them go up to the Springs...and kill the mail party, who were encamped there...the chief said that some one of this party had killed one of his men by giving him poison, and that they were going this morning to take revenge....After much persuasion, they agreed to wait until the party came down to the fort. On the arrival of the party at the fort, they were surrounded by a band of about 90 warriors. Patsearump, the chief...seemed determined on fighting....our interpreter told him that his man had not been poisoned, but was sick before he came to the camp, and it might be possible that he was still alive. The Indian was found alive and given medicine. [Jensen, 1926:278-280] The Indian Chief had no doubt of their right to kill the travelers...but they just naturally wanted the killing to be regular and above-board... The Indians were told that if they went one of the Mormons was going to accompany them because they felt assured there was no cause for bloodshed. Chief Patsearump objected vigorously... [finally] the Indians agreed to do nothing until the mail party came down to the Fort. So the next moming when the mail party arrived they were instantly surrounded by a band of about ninety warriors with Chief Patsearump at their head..." The Mormons suggested that the man might be ill, not dead, and arranged a compromise. They found the Indian man only ill and gave him some medicine. [Squires and Squires, 1955:163-168]

1858 Las Vegas: Mormon mission: interactions between Native Americans and Euroamericans - "Jacob Hamblin wrote that the brethren and Indians on Las Vegas had raised forty acres of corn and wheat [in 1858] but that the mountain Indians had come down and stolen the whole of it." [Jensen, 1926:281]

1858 Las Vegas: Santa Clara River: Mormon mission: interactions between Native Americans and Euroamericans - In September 1858, Mormon "missionaries were called in from the Muddy and Las Vegas Missions on account of the thieving disposition of the Indians at those places. Some of the Indians were willing to work, but would steal everything they could get their eyes upon and the chiefs had no control over them." [Jensen, 1926:281]

1858 Muddy River: Las Vegas: Mormon mission: relations between Native Americans and Euroamericans - In September 1858, the decision was made to abandon the Muddy Mission and the Las Vegas Mission "on account of the thieving disposition of the Indians." [Hafner, 1967:11-12]

1858 Paiutes: Pahrump: Las Vegas: farm labor: Chief Tecopa - O.D. Gass took over the Las Vegas ranch when the Mormons abandoned it in 1858. "[Chief] Tecopa used to spend a good deal of time there. He just loved to take over the management of the Indians who worked on the ranch, and Mr. Gass was perfectly willing that he do so, for, as their chief, he could get more work out of them than anyone. All of them eagerly obeyed his slightest wish. One day, an Indian was accidentally killed and no one was in any way to blame, but there were mutterings and sullen looks, as though the Indians might try to make something out of it. Mr. Gass became frightened, fearful for the safety of his wife and children, so he hurriedly hitched up a team and started for Ivanpah, over 150 miles away, the nearest place 
where he could leave his family. The round trip took about a week. On the way back...they saw old Tecopa sitting on top of the haystack with his silk hat on his head and his red blanket over his shoulders, directing the affairs of the ranch. Everything seemed to be peaceful - the hay had been cut, the fields irrigated, and the crop cared for. When Tecopa saw Gass, he descended from his throne and he extended a welcoming hand and then asked to speak to him in private. Taking him aside, he asked Gass to call on the bereaved widow and ask her what sum would compensate her for the loss of her man...So he made a visit to the tepee of the widow." [Boyer, 1967:77-78]

1858 Paiutes: Owens Valley: hostilities between Euroamericans and Native Americans A party of six Euroamerican men led by J.H. Johnson and a 'Digger Indian' named Sampson skirmished with a party of Paiutes near Kearsarge Pass, west of Independence. Two Paiutes were killed. [Chalfant, 1933:124]

1859 Owens Valley: military expedition - Captain Davidson led a force of 60 men from Fort Tejon to Owens Valley with the aims of locating and reclaiming livestock believed to have been stolen by Native Americans there, punishing the Native Americans responsible, and generally reconnoitering the Owens Valley. Davidson found no stolen stock and concluded that the Native Americans had been unjustly accused. The focus of the expedition shifted to detailed documentation of Native American life in the region. [Wilke and Lawton, 1986:6-7,21-22]

1859 Owens Valley: Native American agriculture - Captain Davidson reported that large tracts of land in the Owens Valley were under irrigation by Native Americans to produce grass seeds and grass nuts (probably Brodiaea capitata). Davidson noted that the Indian fields often extended for miles, as did the irrigation ditches.

"[W]hole fields of this grass, miles in extent, are irrigated with great care, yielding an abundant harvest of what is one of their principal articles of food." Davidson specifically stated that their fields of "grass-nuts" were planted, as well as irrigated: "They are reproduced by planting." In 1859, when Davidson toured the region, there was as yet no Euroamerican settlement in the area. [Wilke and Lawton, $1986: 19,29]$

1859 Paiutes: Owens Valley: population - Captain Davidson estimated a population of 1,200 Paiutes living along "the borders of Owen's Lake and River." [Wilke and Lawton, 1986:29]

1859 Paiutes: Owens Valley: population: aboriginal agriculture - A correspondent who accompanied the Davidson expedition estimated a population of 1,200 to 1,500 for the Owens Valley and reported that "large tracts of land are irrigated by the natives...Their ditches for irrigation are in some cases carried for miles..." [LOS Angeles Star, August 27, 1859, reprinted in Lawton et al., 1976:28]

1859 Owens Valley: relations between Native Americans and Euroamericans - Captain Davidson found the Owens Valley Indian people to be peaceful. He proposed that the valley be made a reservation and made promises to the indians that it would be. [Wilke and Lawton, 1986:21,31]

1859 Western Nevada: mining activities - Discovery of the Comstock Lode led to intensified prospecting throughout Nevada. [Busby et al., 1979:45] 
1859 Owens Valley: mining activities - Gold and silver strikes were made at Monoville (or Mono Diggings). Mining camps developed at Monoville and Dogtown. [Busby et al., 1979:45]

1859 Owens Valley: hostilities between Native Americans and Euroamericans - By 1859 there were a number of hostilities between Native Americans and Euroamericans. [Chalfant, 1933:123]

1859 Owens Valley: Euroamerican settlement - The federal government suspended settlement of several square miles in the vicinity of Independence, pending possible establishment of an Indian reservation there. The suspension was revoked in 1864. [Chalfant, 1933:124]

1850- Whiterock Spring: Tippipah Spring: Fortymile Canyon: Ash Meadows:

60s mail route - On the mail route from Salt Lake City to Los Angeles during the 1850 s and 1860 s, there were relay stations at Whiterock Spring, Tippipah Spring, Fortymile Canyon, and Ash Meadows. "Forty Mile Canyon...probably received its name because of distances traveled on the [Salt Lake-Los Angeles mail] route." [NTS News, vol. XII, no. 16, August 8, 1969, p. 6]

1860-64

1860 Nevada: population: census - According to the 1860 census, Nevada had a population of 6,857 . (This figure does not seem to include the Native American population, which Indian Agents estimated at from several thousand to roughly 10,000.) [Department of the Interior, Census Office, 1870:48]

1860s Paiutes: Pahrump: Native American ranching - Mormon Charlie, a Paiute, started the first stock ranch in Pahrump Valley. [Lingenfelter, 1986:162]

1860s Johnnie district: mining activities - Breyfogle discovered a rich ore deposit in southern Nevada, apparently in the Johnnie district, but as he started back to Austin, Nevada, he was "waylaid by Indians, was partly scalped, and left for dead." He survived and took numerous prospecting parties back to the vicinity of the Johnnie district, but was never able to relocate his discovery. [Tonopah Mining Reporter, vol. IV, no. 3, September 20, 1924, p. 2, col. 4]

1860 Owens Valley: mining activities - Rich ledges were discovered at Coso, southeast of Owens Lake, and there was prospecting activity throughout the valley. [Busby et al., 1979:46]

1860 Owens Valley: mining activities - The Visalia Delta estimated there were 100 prospectors at work in Owens Valley, east and south of Owens Lake, and another 200 prospectors in the Coso area. [Chalfant, 1933:130]

1860 Owens Valley: Euroamerican settlement - A party of Euroamerican settlers established a camp near the later site of Independence. The camp was later moved to the location of the Union Lode. [Chalfant, 1933:139-140]

1860 Owens Valley: interactions between Native Americans and Euroamericans Native Americans paid a friendly visit to the new Euroamerican camp in Owens Valley. [Chalfant, 1933:140] 
1860s Owens Valley: Panamint Valley: mining activities - The first mineral strikes in the Owens and Panamint valleys were made in the early to mid-1860s and centered mostly around the extraction of silver, although lead and gold also appeared in promising amounts. High transportation costs, low yields, expensive machinery unsuited for the job at hand, and falling lead and silver prices soon contributed to the demise of these enterprises. By the late 1870s, the earliest southern Inyo camps were already collapsing. [Greene, 1981:23]

1860s Owens Valley: Panamint Valley: mining activities: relations between Native Americans and Euroamericans - Development of mines in the Death Valley region "during these early forays [exploratory expeditions in the early 1860s] was hindered by the constant threat of attacks by hostile Paiutes who were resentful of the encroachment upon their lands by miners and settlers in the Owens and Panamint valleys. The frequency and ferocity of their attacks led to the establishment of Camp Independence.... This action did not deter the Indians, however, who continued to raid and prey on small groups of settlers and miners.... Severe retaliation by soldiers and citizens alike culminated in 1865 in the slaughter and drowning of about 100 Indians at the mouth of Owens... This act broke the resistance of the Paiutes..." [Greene, 1981:26]

1861 Amargosa Valley: mining activities: hostilities between Native Americans and Euroamericans - In 1861, a party of eight Mexicans began working a gold mine near the Amargosa River bed (discovered in 1856). "W]hen they had built a small mill the Paiutes came along in force, killed all the men, and burned the mill." [Spears, 1892:22]

1861 Paiutes: Nevada: population - The Indian Agent estimated the Paiute population at 6,000. [Ingalls, 1913:35]

1861 Shoshones: Panamint: prospecting - A Native American guide who was later known as George Hansen led Dr. Samuel George to Surprise Canyon, the site of the Panamint mines later on. [Lingenfelter, 1986:125]

1861 Owens Valley: Euroamerican settlers: hostilities between Native Americans and Euroamericans - The first ranches were established in Owens Valley in 1861 by cattlemen. Conflicts between the new settlers and American Indian occupants began almost immediately, as Paiutes fought to defend their lands. [Wilke and Lawton, 1986:7]

1861 Owens Valley: Euroamerican settlers - In 1861, ranches were established near the later sites of Laws and Independence. [Chalfant, 1933:141]

1861 Owens Valley: Euroamerican settlers: livestock - One party of Euroamerican settlers, including Samuel Butler and several of his relatives, and American Indian herders, brought 500 to 600 cattle into the Owens Valley in July 1861. [Chalfant, 1933:142)]

1861 Owens Valley: hostilities between Euroamericans and Native Americans - A Euroamerican herder, Al Thompson, killed an Indian he saw driving away an animal. Indians then captured and killed a man named Crossen, in retaliation. [Chalfant, 1933:148] 
1861 Native Americans: Owens Valley: settlement: fandango - "The principal Indian settlement of the northern part of the valley was on Bishop Creek...Indians from all parts of the valley, and beyond, gathered there in the fall of 1861 and held a big fandango." [Chalfant, 1933:149]

1861 Owens Valley: relations between Euroamericans and Native Americans - The killings and the large social gathering referred to in the preceding two entries "caused great alarm among the scattered settlers and they gladly agreed to a pow-wow with the Indian chieftains...A treaty was drawn up and signed...[but] Within two months war was on in earnest." [Chalfant, 1933:149-150]

1862 Owens Valley: livestock - Drought conditions in western California from 1862 to 1864 led many stockmen to drive their herds into Owens Valley and Mono Basin. [Busby et al., 1979:49]

1862 Owens Valley: trails: roads - construction of a pack trail from Tulare Valley to Owens Lake began. [Chalfant, 1933:135]

1862 Owens Valley: hostilities between Native Americans and Euroamericans - Warfare between Euroamerican settlers and Owens Valley Paiutes began in spring 1862. Military forces were brought in. [Busby et al., 1979:55]

1862 Owens Valley: military post established - Camp Independence was established to respond to the conflicts between Native Americans and Euroamerican settlers. A treaty was soon signed, but Indian Agents and the military were unable to provide the material goods promised to the Native Americans in the treaty, and hostilities resumed. [Chalfant, 1922:21; Busby et al., 1979:56]

1862 Owens Valley: mining activities - Mineral strikes in Owens Valley brought more and more settlers into the area. [Chalfant, 1922:146-147]

1863 Owens Valley: Euroamerican settlers - By 1863, Owens Valley had become a "great thoroughfare" due to mineral discoveries all around the rim of the Great Basin, and due to the drought in western California. The sheep and cattle devoured the seed plants the Paiutes depended on for their winter food supply. [Busby et al., 1979:54]

1863 Owens Valley: hostilities between Native Americans and Euroamericans - There were several major battles in 1863 involving substantial numbers of Native Americans. The military resorted to a scorched earth policy against the Native American people, leading to the surrender of about 1,000 Native Americans in June and July. [Chalfant, 1922:146-147; Busby et al., 1979:56]

1863 Paiutes: Owens Valley: food caches: destruction of food - Soldiers destroyed some 300 bushels of cached seeds in the Bishop Creek area in May 1863. Within a few weeks (on June 4) some 400 Paiutes surrendered at Camp Independence, with more soon following suit. [Chalfant, 1922:190)]

1863 Paiutes: Owens Valley: exile: internment - On July 11, 1863, 908 Owens Valley Native Americans prisoners were started on a march from the military post at Camp Independence to Fort Tejon to be interned there. Indian Agent Wentworth reported that $\mathbf{8 5 0}$ persons arrived at Fort Tejon on July 22, the others having escaped along the way. Wentworth reported that twice as many remained in Owens Valley as had been brought to Fort Tejon. [Chalfant, 1933:194-195] 
1863 Owens Valley: Paiutes and Shoshones: resistance to Euroamerican intrusion Owens Valley Paiutes rose up against white prospectors, joined by Panamint Shoshones. They killed a number of prospectors near Wildrose Canyon. "Other Death Valley and Ash Meadows Shoshone were drawn into skirmishes with the whites before an informal peace was reached about 1867." [Lingenfelter, 1986:19]

1863 Native Americans: Amargosa region: relations between Native Americans and Euroamericans - Jacob Breyfogle, on a prospecting trip in the Amargosa region, camped near the later site of Shoshone with a group of Confederate sympathizers on its way to the Southern armies in Texas. Near dawn, Native Americans attacked the camp, but Breyfogle escaped, barefoot. After several hours of hasty barefoot travel, his feet were swollen too large to put on his boots. He wandered for two days, during which time he stumbled upon some rich ore. He was then found in a delirious state by a party of Native Americans from Stump Springs, who treated him as a captive slave, later trading him to a passing wagon train. The travelers left Breyfogle at the Manse ranch in Pahrump Valley, where Mrs. Yount and Mrs. Harsha White nursed him back to health. Breyfogle accompanied many prospecting parties in efforts to rediscover the location of the gold, but Breytogle's memory had been impaired by his ordeal and the efforts were never successful. [Belden, 1976:21-24]

1864 Native Americans: Amargosa region: interactions between Native Americans and Euroamericans - An article suggests that Breyfogle's 'lost mine' was located in Ash Meadows. "There is an old Indian who has resided about the oasis in this part of Nye County for a great number of years who tells the following story that strengthens my conclusion that Ash Meadows was the place where the 'crazy Dutchman' was in the nick of time saved from death by thirst. While in the Meadows, Breyfogle one night made the Indian camp his headquarters, and the old buck then being a young and observing youth, noticed the pale gold seeker take a new pair of shoes from his pack and don them. They were a treasure in the eyes of the young Paiute, and when the prospector departed the following morning the Indian slipped out and followed the white man in hopes that he would find an opportunity to kill Breyfogle and become the possessor of the bright new shoes. For several days he kept in the wake of the white man, but the intended victim some way becoming aware of his follower's intentions, made the Paiute desist... Later, Native Americans coming from the north reported at the Vegas ranch that a white man had been murdered by a young buck for a pair of shoes the former wore, and as a result parties started out to investigate, and several days later Breyfogle and his chunks of nuggeted ore were found. He had about succumbed." ["Breyfogle Again," Beatty Bullfrog Miner, vol. 1, no. 15, July 1, 1905, p. 5, col. 1]

1864 Paiutes: Resting Springs: interactions between Native Americans and Euroamericans: Ash Meadows Charley - "Ash Meadows Charley, the old warchief of the Paiutes, admitted to me [Herman Jones] that he was with the party which followed Breyfogle's enormous footprints until they came up with him at Stump Spring, near Resting Spring. While Breyfogle was leaning over cooking, one of the Paiutes hit him on the back of the head with a warclub and knocked him out. They...left him for dead, but he recovered and headed north along an old Indian trail." [Coolidge, 1937:63-66] 
1864 Northern Death Valley: mining activities - Silver mining operations were under way by 1864 at Silver Peak, Palmetto, and Montezuma, and mining began soon after at Lida and Sylvania. [Zanjani, 1987:81]

1864 Nevada: mining: impacts on wild foods - "Gold and silver are discovered in many portions of the Territory among large bands of Indians who have recently had undisturbed possession of the country....miners drive away the game and cut down the pine-nut tress, upon which the Indians subsist." [CIA, 1865:142]

1864 Nye County - Nye County was established in an area that had previously been part of Esmeralda County. [Kral, 1951:1]

1865-69

1865 Paiutes: Timpahute area: commerce - Local Paiute women salvaged iron tires from wagons abandoned by the forty-niner emigrants in the vicinity of the Timpahute Range and rolled them 25 miles to the mining camp at Pahranagat where a blacksmith bought them. [Lingenfelter, 1986:41]

1865 Native Americans: Belmont: Native American prospecting - Gold in the Belmont area was first discovered by a Native American in October 1865. [Cook, nd:150]

1865 Pahranagat: mining activities - Silver was discovered in the Pahranagat area and the Pahranagat district was organized. [Sadovich, nd:246]

1865 Pahranagat: hostilities between Native Americans and Euroamericans - Native American hostilities drove miners out of Pahranagat Valley in the summer of 1865 . [Sadovich, nd:246]

1866 Shoshones: Nevada: population - The Indian Agent estimated a Shoshone population of 2,500, occupying almost the whole eastern half of the State of Nevada. [CIA, 1866:114]

1866 Shoshones: Nevada: employment - The Indian Agent reported that around Austin and along the overland mail route, Shoshones were employed by whites; the men cutting wood, cultivating gardens, and running errands; the women doing laundry. [ClA, 1866:114]

1866 Paiutes: Nevada: population - The Indian Agent estimated a Paiute population of 4,200. [CIA, 1866:115]

1866 Paiutes: Nevada: employment - The Indian Agent described Paiutes as temperate, chaste, industrious, efficient, and faithful workers. [CIA, 1866:115]

1866 Shoshones: Paiutes: territories - The Indian Agent noted that the line separating the Shoshones from the Paiutes to the east and south was not very clearly defined. [CIA, 1866:114]

1866 Native Americans: Nevada population - The Indian Agent estimated a total population of about 10,000 Indians in Nevada, dispersed over the entire country, living in small bands. [CIA, 1866:117]

1866 Native Americans: Nevada: employment - The Indian Agent reported that Paiutes were extensively employed throughout the country, especially during the harvest season, and were employed in the towns and mining camps in large numbers. [CIA, 1866:119] 
1866 Hiko: population - In 1866, Hiko had a population of about 200 . The following year, a post office was opened. [Sadovich, nd:248; Carlson, 1974:134]

1867 Shoshones: Nye County: agriculture - An Indian Agent traveled to Big Pine Mountains (90 miles east of Belmont), found a camp of 30 American Indians with crops of corn, bean, squash, etc., and noted that many had never seen a white man before. [CIA, 1868:170]

1867 Paiutes: Nye County: interactions between Native Americans and Euroamericans - After a "desperado" assaulted several peaceful Paiutes in the Mammoth district and compelled them to pay him for an ox they did not kill, influential Euroamericans protested in writing to the Indian Agent, asking that the Indian people be treated justly. [CIA, 1868:171]

1867 Shoshones: Nye County: residence in towns - The Indian Agent reported that a majority of Native Americans in southeastern Nevada were camped in the vicinity of mining towns. [CIA, 1868:172]

1867 Shoshones: Belmont: Nye County: residence in towns - The Indian Agent saw 300 Shoshones at Belmont (100 miles southeast of Austin). [CIA, 1868:172]

1867 Native Americans: Nevada: mining: Native American prospecting - The Indian Agent stated that nearly all the rich mines in southeastern Nevada were discovered and made known to whites by Native Americans. [CIA, 1868:173]

1867 Paiutes: Walker River: epidemic - Seventy-five to one hundred Native Americans died at Walker River, with causes of death listed as ague, bilious, and typhoid fevers. "So many Paiutes were aftlicted by illness that they were unable to go to the mountains for fall gathering of pine nuts, but rather were forced to go to Virginia City to do light work to earn money for their winter's keep." [CIA, 1867/ 68:146-147, cited in Hittman, 1973:73]

1867 Shoshones: Owens Valley: Native American prospecting - A Shoshone man at Big Pine Mountain offered to lead the Indian Agent to a silver lode. [CIA, 1868:173]

1868 Timpahute district: mining activities - Lead and silver ore were discovered in the Timpahute Range in 1868. [Carlson, 1974:232]

1869 Shoshones: Nevada: territories - The report of the 1869 Wheeler expedition stated that Shoshone territory extended "as far south as 37 degrees 30 minutes of latitude" and "as far south as Tim-Pah-Ute Mountain, and to the east as Ruby Valley." [Wheeler, 1875:27,36]

1869 Paiutes: Spring Mountains: camps - The report of the 1869 Wheeler expedition mentioned finding Paiute camps at several locations in the Spring Mountain Range. [Wheeler, 1875:37]

1869 Paiutes: Spring Mountains: Las Vegas: population - The report of the 1869 Wheeler expedition stated that "[t]he Indians in the vicinity of Las Vegas are the Pahutes, and vary in numbers from fifty or sixty to one hundred and fifty or two hundred, according as they see fit to live in the valley, or keep to the mountains. Some of these at times make their wick-e-ups about El Dorado Canon, and again a few near Cottonwood Island, on the river; while the most of these same Indians 
are found in the mountains of the Spring Mountain range, and to the northwest from the Vegas, numbering as high as three or four hundred, all told. As some of these Indians could speak Shoshone, it was concluded that our guide would be able to gather from some of them information about getting north from Indian Springs. The result proved quite fortunate in giving us a knowledge of one of the worst forced marches of the trip." [Wheeler, 1875:21]

1869 Paiutes: Nevada: territories in Nevada - The report of the 1869 Wheeler expedition stated that "[t]he Utes, Utahs, or Piedes, as they have sometimes been called...are found from Pahranagat Valley to the mouth of the Virgin River as the most westerly line of their country..." and that for the "Pah-Utes, or WaterUtes....Their eastern limit is the western one of the Utes or Piedes; the Colorado bounds them on the south, and to the north and west the Great Death Valley of Southwestern Nevada, that almost extends to and joins Death Valley proper in California. We found their wick-e-up at Las Vegas Ranch, at various points on the Spring Mountain range, and some few at Eldorado Canyon and below, in and about Cottonwood Island." [Wheeler, 1876:36-37]

1869 Paiutes: agriculture - The report of the 1869 Wheeler expedition stated that the "Utes or Piedes [identified as "found from Pahranagat Valley to the mouth of the Virgin River as the most westerly line of their country...7] cultivate the soil..."; and that "The Pah-Utes, or Water-Utes.... [whose] eastern limit is the western one of the Utes or Piedes.... plant but little, living for the greater part on pine-nuts, which are very plentiful, and by hunting, which around these mountains is better than at any point along the route." [Wheeler, 1876:36-37]

1869 Paiutes: interactions between Native Americans and Euroamericans - The report of the 1869 Wheeler expedition said of the Paiutes that "[t]hey have seen and mixed with many whites, principally on the old emigrant road; know well the value of money, and have a great desire for clothes and blankets. They make frequent pilgrimages, and always return well-laden with spoils, both in wardrobe and funds. They plant but little, living for the greater on pine-nuts, which are very plentiful, and by hunting, which around these mountains is better than at any point along the route." [Wheeler, 1876:37] '

1869 Paiutes: slave raids - The report of the 1869 Wheeler expedition said of the "Utes or Piedes" that "this tribe has been for long years at enmity with the Navajoes, who have been in the habit of crossing the Colorado and making inroads upon the Utes and Piedes, taking their stock, squaws, or anything else, and then beating a hasty retreat." [Wheeler, 1876:37]

1869 Nevada: drought - The years 1869 and 1870 represented a period of severe drought that crippled production of pinyon nuts and grass seeds and led the Indian Agent to warn of impending starvation for Indian people. [Hittman, 1973:71]

1869 Timber Mountain district: Groom district: mining activities - The report of the 1869 Wheeler expedition noted that the "Tim-Pah-Ute mines...are situated in the southern end of a short detached range to the northeast from Tim-Pah-Ute Peak..." and describes the "Groom District...[as] situated to the south and west from Tim-PahUte Peak...This district was not being worked by any miners in November last, but I understand that since that time parties have one there to make some developments." [Wheeler, 1876:23] 
1869 Timber Mountain district: mining activities - Galena ore was discovered and claims entered in 1869. [Pippin and Zerga, 1983:56]

1869 Timber Mountain district: mining activities - Galena and silver ore discoveries were made in 1869 in the Timber Mountain district, located in the Spring Mountains, and including the area later known as the Johnnie district. [Carlson, 1974:231; Wheeler, 1872:52]

1869 Native Americans: Nevada: water resources - "These fountains, both mineral and thermal, are much frequented by the Indians for their supposed medicinal virtues." [Browne, 1869:307]

1860s Death Valley: interactions between Native Americans and Euroamericans "[R]enegade" Euroamericans lived in Death Valley, along with the Paiutes there. [Spears, 1892:23]

1860s Meadow Valley: Panaca: hostilities between Native Americans and Euroamericans - John N. Lee, witness in a mining suit, testified regarding Native American hostilities in the Panaca area of Meadow Valley: "[W]e had stock stolen in 1866 by the Indians.... think the Indians in 1868 killed two or three men down in the canyon; don't know who they killed in 1869; there has always been danger here till the country was thoroughly settled... We took Indian prisoners and had to kill them to save our lives....from their trying to steal our weapons and stealing our stock in July, 1864 , originated the troubles..." Barber, another witness, testified that in Clover Valley "the settlers had trouble with the Indians; one Indian was killed in Clover Valley and one hung; Indians were killed at Panaca; a white man, named Rogers was killed by the Indians; in the early part of 1866 two white men were killed by Indians on the Muddy; in 1864-5-6 the settlers stood guard.... an Indian said he killed him [Rogers] on the Pahranagat road, eight miles beyond Bennett's Springs....the Indian said his father told him he couldn't be a brave till he killed a white man, and he watched till Rogers came along, decoyed him off to show him 'panaca' or 'white metal,' and thus killed him.....we didn't think it was safe to be out away from a settlement in $1866 . .$. there were 10 or 15 Indians killed to one white man..." ["The Great Mining Suit," Pioche Daily Record, vol. 6, no. 13, April 1, 1873, p. 3, col. 3]

1860s Paiutes: Shoshones: interactions between Native Americans and Euroamericans "By 1868 most of the Numic cultures were undergoing a period of rapid transition. Some groups had been dispossessed of their land and resources. Settlers and miners had moved into the best areas, fenced and plowed the land and turned livestock into valuable seed-gathering areas. In some locations pinyon pine, a major food resource for the Indians, had been cut for firewood, fenceposts, and mining timbers." [Fowler and Fowler, 1971:14]

\section{0-72}

1870 Nye County: population - According to the 1870 census, Nevada had a total population of 42,491 and Nye County had a population of 1,087. [Census Office, vol. 1, 1870, p. 48]

1870s Pahrump: ranching - More than a dozen ranches were established at Pahrump in the 1870s. [Lingenfelter, 1986:166] 
1870s Shoshones: Beatty: camps - There were half a dozen Shoshones in Oasis Valley in the vicinity of Beatty around 1875 or 80 , giving the area a total of about 29 people. This number included people at the mouth of Beatty Wash, at Hick's Hot Springs, at Goss Springs, and at Howell Ranch. [Steward, 1938:93]

1870s Shoshones: Panamint: wood haulers - George Hansen, a Panamint Shoshone man, worked as a 'wood-packer' at Panamint City in the early 1870s. [Hubbard et al., 1965:33]

1870s Timpahute district: mining activities - Lead and silver were mined in the Timpahute district from 1870 through the early 1880 s. There was a post office in the area from 1879 to 1883 . [Carison, 1974:232]

1870 Owens Valley: Native Americans: population - The 1870 census counted 1,150 Native Americans in Owens Valley, a reduced figure after the warfare and removal of 1863. [D.C. Cragen, The Boys in the Sky-Blue Pants: The Men and Events of Camp Independence and Forts of Eastern California, Nevada, and Utah, 18621877, Pioneer Publishing Company, Fresno:88,187. Cited in Busby et al., 1979:57]

1871 Spring Mountains: Paiutes: employment: guides: messengers: interactions between Native Americans and Euroamericans: mining activities: Wheeler expedition - The report of the 1871 Wheeler expedition stated that "[f]rom among the Pah-Utes, in the Spring Mountain Range, often as many as seven or eight guides and messengers were employed at one time. These Indians have been considered friendly for some years, but frequently prospectors, in parties of two, going out into the mountains, never return. They have, however, a wonderful regard for a superior force." [Wheeler, 1872:28]

1871 Paiutes: Pahrump: agriculture: Wheeler expedition - The report of the 1871 Wheeler expedition stated that the "Pah-rimp Desert...extends south for miles, and skirts the Spring Mountain Range. This desert contains several beautiful little oases, the principal one being at Pah-rimp Springs, at which point are located quite a number of Pah-Ute Indians, very friendly and quite intelligent. These Indians raise corn, melons, and squashes. Great quantities of wild grapes were found around these springs." [Wheeler, 1872:84]

1871 Native Americans: Ash Meadows: messenger: hostilities between Native Americans and Euroamericans: Wheeler expedition - At Ash Meadows, "Wheeler tried to get an Indian to take a note to his brother at a point 70 miles distant. The Indian asked for five dollars, a shirt and a pair of pants as pay. This was refused and he left camp. The next morning he returned, with four others. All were seized and tied up. One broke away, started to run, and was shot and killed. The rest of them set out, under guard, with the note; the corporal reported that they had run away, with shots flying after them. In this dilemma Wheeler concluded to go himself, with an orderly. He was surrounded, somewhere during his trip, by a dozen Indians, and would have been killed had it not been for the interposition of a Salt Lake Indian with the crowd." [Chalfant, 1922:224]

1871 Central Nevada: drought - The period of drought which began in 1869 extended into 1871. The Indian Agent noted that "[t]he present year is lamentably unfavorable for their [Paiutes] desires as the unparalleled drought in this country has entirely cut off the supply of bunch grass, and consequently no seeds to be gathered; 
also the supply of pine nuts has shared the same fate. Thus the Indians have had to depend almost wholly upon their fish and game, though the increased demand has greatly reduced the game until that supply is now quite limited." [CIA, 1870/ 71:558, cited in Hittman, 1973:71]

1872 Paiutes: Nevada: population - The Indian Agent estimated a population of 6,000 Paiutes, with their population growing rapidly. The agent was impressed with the numbers of youth and small children. [CIA, 1872:285]

\section{3-74}

1873 Paiutes: Shoshones: territories: political organization - According to Powell and Ingalis, "[t]he original political organization of the tribes under consideration had a territorial basis; that is, the country was divided into districts, and each district was inhabited by a small tribe, which took the name of the land, and had one principal chief. These tribes, of 'land-nameds,' as they are called in the Indian idiom, were the only permanent organizations, but sometimes two or more of them would unite in a confederacy under some great chief." [Powells and Ingalls, 1874:10]

1873 Paiutes: aboriginal agriculture - Indian Agent G.W. Ingalls reported that "[t]he PaiUtes have always been an agricultural people, and their history can be traced back for more than one hundred years, which sustains this statement." [Ingalls, 1913:87]

1873 Paiutes: Shoshones: Great Basin: political organization: territories - J.W. Powell reported that all the Numic peoples "have well-defined governmental organizations. The unit of political organization is the family presided over by some patriarch." "From half a dozien or two or three score of such families may be organized into a tribe. Over such a tribe there is a principal or executive chief, sometimes also a war chief and sometimes a chief of the council..." "The whole of the region of country occupied by these tribes numbering two or three hundred, is divided into districts with lines separating them, well defined, usually by natural objects and to each of such districts there belongs a tribe of indians who take the name of the land and the Indians are fixed to this land. If they cultivate the soil it must be in this district; they must hunt in this district; they must gather roots and seeds and nuts in this district." "An Indian will never ask to what nation or tribe or body of people another Indian belongs but to "what land do you belong and how are you land named? Thus the very name of the Indian is his title deed to his home and thus it is that these Indians have contended so fiercely for the possession of the soil, for a tribe to yieid the district which it inhabits they must lose their nationality and become incorporated in other tribes and perhaps to do so it becomes necessary for them to fight for a recognition. His national pride and patriotism, his peace with other tribes, his home and livelihood for his family, all his interests, everything that is dear to him is associated with his country." [Powell Manuscript \#798, published in Fowler and Fowler, 1971:37-38]

1873 Paiutes: aboriginal agriculture - J.W. Powell noted that "[a]ll the Pai-Utes subsist in part by cultivating the soil, some of them raising the grain and vegetables introduced by white men, others cultivating native seeds...Prior to the settlement of the country by the white men they all [the Paiute tribes] cultivated the soil, and would do so now to an extent sufficient to obtain a living, if they had the lands in the districts of country which they severally occupy.... Previous to the advent of white 
men in Utah, the Indians were raising corn, squashes, and other grains, and vegetables. Among the tracts of land thus cultivated, there were four remarkable for their extent, one in a little valley along a stream, tributary to the San Pete, now known as Twelve-Mile Creek, another at Com Creek, near Fillmore, a third at Spanish Fork, on the shore of Utah Lake, and a fourth at Deep Creek, near the Nevada line." [Powell and Ingalls, 1874:3,14,19]

1873 Paiutes: Southern Nevada: populations: tribal groupings: regional political organization: regional link - See Table 3.

1873 Paiutes: Shoshones: religious beliefs - J.W. Powell noted that the Numic people believed in "a great number of beings whom we may call demons. The air above, the earth beneath, the waters, the recesses in the rocks, the trees, everything is peopled by strange, weird beings. [Fowler and Fowler, 1971:75]

1873 Native Americans: Pioche: epidemic deaths - "The Indians around Pioche continue to perish, unattended and uncared for, in the sagebrush..." ["Still Dying in the Sagebrush," Pioche Daily Record, vol. 6, no. 24, April 19, 1873, p. 3, col. 1]

1873 Shoshones: Paiutes: Pioche - "Yesterday...a Shoshone Indian, known as 'Captain Andy,' tried to forcibly take a Shoshone squaw away from a house on Lacour street...the crowd rapidly increased, many of whom were Indians....'Bill Robinson,' half Paiute and half Shoshone...gives the following version...." ["Excitement over a Shoshone Squaw," Pioche Weekly Record, vol. 6, no. 7, March 25, 1873, p. 3, col. 2]

1873 Native Americans: Death Valley region: agriculture - Travelers to the gold fields of Lida and Gold Mountain saw a Native American farm north of Death Valley "under a high state of cultivation. The proprietor is always to be seen diligently at work upon his property. He is an aged and remarkable sedate-looking old Paiute, who is known as 'Billy Rogers'." [Greene, 1981:362-63]

1873 Ash Meadows: livestock - Charles King ran a herd of 1,300 cattle in Ash Meadows atter purchasing them in southern California. He sold beef to miners at Ivanpah and in the Panamints. [Zanjani, 1987:62]

1873 Ash Meadows: livestock - "Thirteen hundred head of cattle, one thousand being cows, and all American stock, have been driven into Ash Meadows, in the southwestern portion of this county. bCharles Foreman and Charles King are the proprietors. The animals were purchased in Califomia. Messers. Foreman \& King are making permanent improvements and intend to give their entire attention to stock raising in Lincoln county." ["A Big Live Stock Enterprise," Pioche Weekly Record, vol. 5, no. 143, March 4, 1873, p. 3, col. 3]

1873 Paiutes: Nevada: employment - The Indian Agent noted that scattered bands of Paiutes in westem Nevada are employed by Euroamericans, who preferred that Indians stay among them rather than be placed on reservations, "as they need their help and say they could not get along without them." [Secretary of the Interior, 1874:4]

1873 Shoshones: Nevada: employment: herders - The Indian Agent noted that some Shoshones were employed by Euroamericans in herding and other labors. [Secretary of Interior, 1874:4] 
Table 3. Southern Paiute Tribal Groupings, Populations, Political Leadership, and Regional Links, $1870 \mathrm{~s}^{\mathrm{a}, \mathrm{b}}$

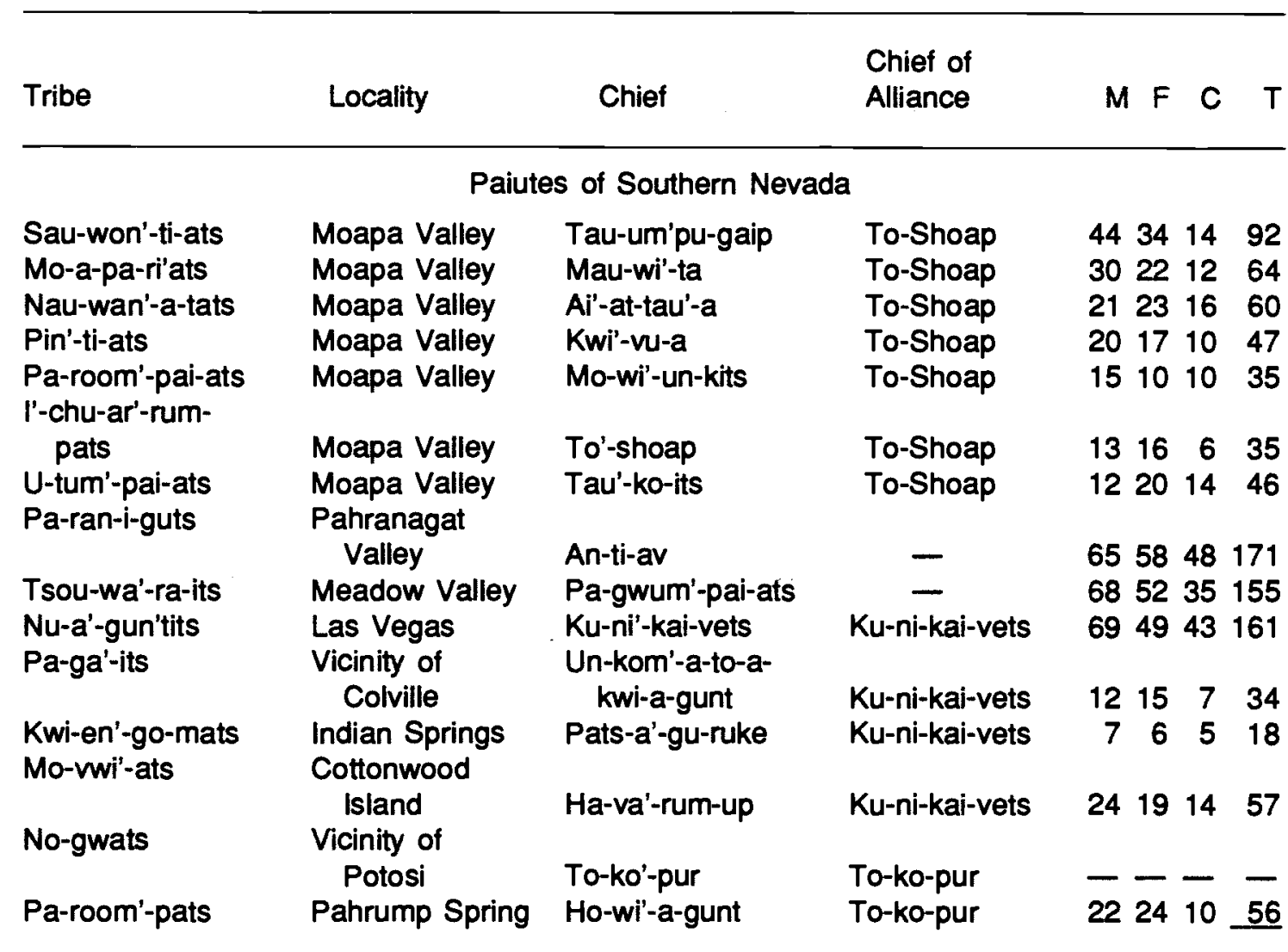

Sum Total

Paiutes of Southeastem California

\begin{tabular}{|c|c|c|c|c|}
\hline $\begin{array}{l}\text { Mo-quats } \\
\text { Ho-kwaits }\end{array}$ & $\begin{array}{l}\text { Kingston Mtn } \\
\text { Vicinity of } \\
\text { Ivanpah }\end{array}$ & $\begin{array}{l}\text { Hu-nu'-na-wa } \\
\text { Ko-isi'-an }\end{array}$ & $\begin{array}{l}\text { To-ko-pur } \\
\text { To-ko-pur }\end{array}$ & $\begin{array}{l}--- \\
343417\end{array}$ \\
\hline $\begin{array}{l}\text { Tim-pa-shau-wa- } \\
\text { got-sits } \\
\text { Kau-yai'-chits } \\
\text { Ya'-gats }\end{array}$ & $\begin{array}{l}\text { Providence Mtn } \\
\text { Ash Meadows } \\
\text { Armagosa }\end{array}$ & $\begin{array}{l}\text { Wa-gu'-up } \\
\text { Nu-a'-rung } \\
\text { Ni-a-pa'-ga-rats }\end{array}$ & $\begin{array}{l}\text { To-ko-pur } \\
\text { To-ko-pur } \\
\text { To-ko-pur }\end{array}$ & $\begin{array}{lll}\overline{10} & -\overline{12} & - \\
31 & 23 & 14\end{array}$ \\
\hline
\end{tabular}

Sum Total . . . . . . . . . . . . . . . . . . . . . . . . . . . . . . . . . . .

adapted from "Tabular Statement of Indians Visited by Special Indian Commissioners J.W. Powell and G.W. Ingalls" (Powell and Ingalls, 1874:11-12).

bey to columns: $M=$ male, $F=$ female, $C=$ child under ten, and $T=$ total. 
1873 Disease: smallpox: Utah - The Pioche newspaper called "attention to the fact that small-pox exists and is rapidly spreading in the Utah settlements, and repeat the suggestion that it would be well for our physicians to provide themselves with vaccine." [local news column, Pioche Daily Record, vol. 6, no. 4, March 21, 1873, p. 3, col. 2]

1873 Panamint area: mining activities - Copper-silver ore was discovered in Surprise Canyon in 1873 and a road was completed through Panamint Valley up into Surprise Canyon in 1874. The boom in this area lasted only until 1876. [Greene, 1981:29]

1874 Native Americans: Hiko: Bullionville: camp: hostilities between Native Americans and Euroamericans - Native Americans attacked and killed a party of Euroamericans near Hiko. Afterward, the Native American people involved returned to the Native American camp near Bullionville. [local news column, Pioche Daily Record, vol. 9, no. 77, December 17, 1874, p. 3, col. 1]

1874 Native Americans: Hiko area: hostilities between Native Americans and Euroamericans - "The Eureka Sentinel of the 10th instant has the following in relation to the killing of two white men and the wounding of a third by Indians, on the road between Pioche and Panamint...about seven miles from Hiko..." The party was met by "nine Indians - members, it is supposed, of Tempiute Bill's band...The Indians had a good many inquiries to make, and their style of talk and their actions caused Horan to suspect something was wrong. The Indians apparently wanted to lure them off the trail...The whole settlement was at once up in arms... and have sent out parties for the purpose of dealing out a proper punishment..." [Inyo Register, vol. 5, no. 235, December 19, 1874, p. 3, col. 4]

1874 Panamint area: mining town - The camp of Panamint had a population of 2,000 in 1874. [Lingenfelter, 1986:123]

1874 Paiutes: Nevada: political organization: territories: tribal groupings - The Indian Agent noted of the Paiute that "[t]heir hunting grounds have been spoiled, their favorite valleys are occupied by white men, and they are compelled to scatter into small bands in order to attain subsistence. Formerly they were organized into nations, or confederacies, under the influence of great chiefs.... The broad territory over which they are scattered has been parceled out among the tribes by common consent usually determined at general councils, so that each tribe holds a certain district of the country as it's own." [Secretary of the Interior, 1874:4]

1874 Paiutes: Nevada: aboriginal agriculture - The Indian Agent stated that, prior to white settlement, all the Paiute tribes cultivated the soil and continued to do so, but that they now lacked sufficient land. [Secretary of the Interior, 1874:14]

1874 Paiutes: Nevada: employment - The Indian Agent noted that Euroamericans frequently expressed their need for Indian people to help in houses, mines, and ranches. [CIA, 1874c:280-81] 
1874 Native Americans: Nevada: railroad travel - The Indian Agent noted that Nevada Indians had the permission of the railroad companies to ride at their pleasure without regard to government policy requiring written permits for Indians to leave their reservations. [CIA, 1874C:281]

1875-79

1875 Indian Springs: Paiutes: Euroamerican settlement - Andrew Jackson Laswell "bought the Paiute rancheria at Indian Springs and made it a popular way station on what had become the main road from Pioche to the Death Valley camps." [Lingenfelter, 1986:164]

1875 Native Americans: Nevada: employment - The Indian Agent reported that Indian labor was in demand in "all the departments of labor throughout the State" and that if this labor were denied, it would cause "hardship to many citizens in certain localities, as without Indian help laborers would be scarce." [CIA, 1875:339]

1875 Native Americans: Indian Springs: Euroamerican settlers - "Andy Lazwell and Charley King have recently purchased Indian Springs ranch from the Indians. Indian Springs ranch is a beautifully watered spot about sixty miles this side of the Vegas rancn." [Pioche Daily Record, vol. 11, no. 15, October 3, 1875, p. 3, col. 2]

1875 Pahrump: Native Americans: Euroamerican settlers: interactions between Native Americans and Euroamericans - At Manse in 1875 Joseph Yount wife and family settled because the Indians killed their horses and they could travel no further." ["Manse White's Springs and the Garden Spot in the Desert," Beatty Bulfrog Miner, vol. 2, no. 27, September 23, 1905, p. 3, col. 4]

1876 Ash Meadows: Native Americans: Euroamerican settlers: interactions between Native Americans and Euroamericans - In 1876, the Yount family emigrated from Oregon and wintered in Ash Meadows. They brought 75 cows and "a large number of fine horses." In the Fall, the Yount boys were away at various mining locations and Mr. Yount left for San Bernardino to replenish their supplies, leaving Mrs. Yount and the three youngest children alone. During this time "an Indian chief known as Hos Killim" killed eight of Yount's fine horses. Horseshutem Springs, about four miles east of Johnnie, is probably named after this event. [Brooks, 1970:10-11,39]

1876 Ash Meadows: Native Americans: Euroamerican settlers: interactions between Native Americans and Euroamericans - A party of three families and three cowpunchers totaling 19 persons and led by Joseph Yount left Oregon with 400 cattle and a herd of about thirty horses on its way to a gold strike in Tombstone, Arizona. They reached the Pahranagat Valley in October 1876. There cattle rustlers stole about 50 of their cattle and the party spent several days tracking down the livestock. At Pahranagat, the party decided not to proceed to Arizona. The Harsha White family wintered in Hiko. The C.W. Towner family bought the Indian Springs ranch from Andy Laswell. The Yount family drove the livestock south to the Ash Meadows area, passing by the Groom mine and Indian Springs. While pastured in the mountains near Johnnie, the work horses were killed by Native Americans. "The Indians had killed all the work horses, which they knew by the collar marks. The reason that they killed only the work horses was to cripple the settlers so they could not go on with the cattle as the Indians were killing the 
cattle and drying the meat. ...Both the leading renegade Indians were later killed by the tribe Indians who were peaceful." Yount traded his cattle for a ranch in the Pahrump Valley, about six miles from the ranch of Mr. Bennett. Mr. Bennett told Yount that the Indians who killed his horses were renegades; that most of the Paiutes were peaceful and that a great many of them were employed on his ranch. [Doherty, 1974:166-167]

1876 Indian Springs: Euroamerican settlers: interaction between Native Americans and Euroamericans - In 1876, Charles W. Towner purchased Indian Springs from an Indian Chief, Whispering Ben. "This piece of property had been in Ben's family for many years and old Ben had been born there." [Squires and Squires, 1955:334]

1876 Native Americans: Nevada: employment - The Indian Agent noted that "Indians are employed as farmhands, herdsmen, and in the kitchens of ranchers, in much greater numbers and with as much satisfaction as most other laborers, and exceed the chinaman in every department where employed, with perhaps the single exception of cooking." [CIA, 1876:117]

1876 Shoshones: Nevada: employment - The Indian Agent reported that many Shoshone were employed by whites as servants, domestics, and herdsmen. [CIA, 1876:117]

1876 Shoshones: Nevada: agriculture - The Indian Agent reported that the Shoshones who farmed throughout eastern Nevada were losing their land and water, with Euroamerican settlers taking their croplands and appropriating their water sources. [CIA, 1876:117]

1876 Shoshones: Nevada: impacts on wild foods - Chief Tsa-wie (Good Knife) complained that the game was all gone, the pine nut trees cut and burned in the quartz-mills, the grass-seed lands cut by whites for hay before the seeds ripen, and the good lands taken by whites. [ClA, 1876:117]

1876 Shoshones: Nevada: population - The Indian Agent estimated a Western Shoshone population of 4,000 and indicated that the estimate of just under 2,000 made by an earlier agent in 1873 was erroneous. [CIA, 1876:118]

1876 Owens Valley: Native Americans: epidemic - A severe epidemic of measles in Owens Valley was reported by the Inyo Independent. [Chalfant, 1922:32]

1877 Native Americans: Nevada: residence in towns - The Indian Agent reported that a majority of off-reservation Indians had congregated along the line of the railroad (across northern Nevada) at "every little station and town." [CIA, 1877:150]

1877 Paiutes: Pahrump: Native Americans: population - In spring 1877, the Yount family moved from Ash Meadows to Pahrump. Yount wrote that "Mr. Bennett, six miles distance, is our only neighbor, except that we consider the hundreds of roving Paiutes neighbors." [Brooks, 1970:11]

1877 Native Americans: Nevada: railroad travel - The Indian Agent reported that "[t]hey [Nevada Native Americans] ride upon the cars at will; never a train passes either way but that Indians can be seen piled up on the platiorms of the cars." [CIA, 1877:150] 
1877 Shoshones: Nevada: employment: farm labor - The Indian Agent reported that the Shoshones were peaceable and industrious. Many of them worked as farmhands, "some driving teams of 4 and 6 horses, others chopping, mowing, and doing all manner of farm work." [CIA, 1877:152]

1878 Paiutes: Pahrump: Native American prospecting: Chief Tecopa - Chief Tecopa showed Yount the Boss mine and the Columbia mine in the Yellow Pine district. The Younts, Harsha White, and other investors formed the Yellow Pine Mining Company which took in the Potosi Mountains, Manse ranch, and the Charleston Mountains. [Doherty, 1974:168]

1878 Native Americans: Pioche: relations between Native Americans and Euroamericans - "A week since one Latapie, a Frenchman, and a man named Johnston, left here to go to the mountains west of Pioche for the purpose of cutting wood. The first day out, as they were engaged in cooking...they observed at a distance a band of Indians on horseback, moving in their direction. They immediately imagined that the Indians looked hostile... [and fled. Later] they made their way to the eight-mile house, where... Hazeltine...stated that a band of Indians had passed by, engaged in moving their wickiups to another quarter..." ["Another Indian War," Pioche Weekly Record, vol. 17, no. 18, January 11, 1879, p. 3, col. 3]

1879 Native Americans: Pahranagat: Moapa: hostilities between Native Americans and Euroamericans - Native Americans killed a Euroamerican man at Pah Rock Springs in September. "The Indians in the neighborhood of Pah Rock Springs are renegades from the Moapa reservation and very seldom hang around the settlements, but are a band of desperadoes who live off of plunder....This band...is composed of the remnants of Tem Paiute Bill's band, who killed Roberts and another man from Pioche...en route for Panamint in the Spring of '75. ... There has been several disturbances out in that neighborhood since then, and one time the troops stationed at Fort Cameron, Utah, in the dead of winter, were compelled to march from there to Pahranagat Valley..." ["Killed by Indians," Pioche Weekly Record, vol. 19 , no. 10 , November 22,1879 , p. 3, col. 1]

1879 Shoshones: Nevada: farming - The Indian Agent reported that most Shoshones south of the railroad resided on their own small farms or ranches, except for seasonal departures to hunt and to gather pinyon nuts. [CIA, 1879:104]

1879 Shoshones: Nevada: residence in towns: prostitution - Chief Timoke stated that many Shoshones were living around the mining camps and railroad towns, subsisting on food thrown away by restaurants and boarding houses, and that many "squaws" were working as prostitutes. [CIA, 1879:105]

1879 Paiutes: Northern Nevada: employment - The Indian Agent reported that Paiutes had been leaving their reservations due to crop failure, insufficient irrigation ditches, and encroachment by whites. Many left to work on ranches, around the mining camps, and around the railroad towns. [CIA, 1879:109]

1879 Oasis Valley: ranching - Eugene Lander started a ranch near what later became the town of Beatty. [Lingenfelter, 1986:167]

1870s Death Valley area: Panamint: towns - By the early 1870s, Panamint City had a population of 2,000. [Zanjani, 1987:81] 
1870s Paiutes: Virginia City: employment: woodcutters - "[l]t is not unusual to see a Paiute brave marching through a street in Virginia City with a wood-saw and buck under his left arm, and upon his right shoulder an axe." [Dequille, 1876:196]

1870s Paiutes: towns - "The Paiutes swarm about the towns." [Dequille, 1876:196]

1870 S Paiutes: Virginia City: camp - The Paiutes lived on the slopes of the mountains surrounding Virginia City. [Dequille, 1876:214]

1870s Paiutes: Virginia City: employment: woodcutters - "Paiute squaws" served as the scavengers of the town. Paiute males worked as wood cutters. [Dequille, 1876:214]

1870s Paiutes: Nevada population - The Paiute population was growing rapidly: "Even very old women are having children." [Dequille, 1876:216]

\section{0-84}

1880 Nye County: population - According to the 1880 census, Nevada had a population of 62,266 and Nye County had a population of 1,875. (Detailed census rolls for the 1880 Nevada census were destroyed by fire.) [Department of the Interior, Census Office, 1890:1]

1880 Paiutes: Nevada: agriculture - The Indian Agent noted that "Pahutes...by some unaccountable predilection seem naturally inclined to agriculture..." [CIA, 1880:124, 125]

1880 Paiutes: Moapa region - The Indian Agent noted that due to the limited resources of the reservation "the Indians are scattered over the surrounding country for 200 miles around," working, begging, root-digging, and insect-eating. [CIA, 1880:127]

1880 Shoshones: Ash Meadows: Native American camp: interaction between Native Americans and Euroamericans - A Euroamerican man named Rockwell stole a mule from Shoshone people at Ash Meadows. The people apprehended him, took all his possessions, and set him free. He returned to the Shoshone camp at night and killed four Shoshones. [Lingenfelter, 1986:141]

1880 Ash Meadows: Euroamerican setters - Aaron and Rosie Winters settled in Ash Meadows. [Spears, 1892:56]

1880 Fortymile Canyon: prospecting: hostilities between Native Americans and Euroamericans - One of the survivors of the party of forty-niner emigrants who traversed the Fortymile Canyon area in 1849 is reported to have shown a prospector near Barstow some rich ore. The forty-niner claimed to have found the ore in Fortymile Canyon near a spring with a cottonwood close to a conjunction of several Indian trails. The prospector set out to find the spring in about 1880 . He found the general area, but was attacked and driven away by Indian people. [Carrara Obelisk, vol. 2, no. 1, May 8, 1914, p. 6, col. 3]

1881 Native Americans: Snake Indians: murder: Pioche - "[T]he Indians around Pioche discovered that one of their number had been murdered...It was discovered that he had been killed by a Snake Indian called 'One-Eyed-Jack'...The Indians here pursued Jack as far as Bristol..." ["Indian Killed," Pioche Weekly Record, vol. 21, no. 19, January 29, 1881, p. 3, col. 1]

1881 Paiutes: Nevada: employment: herding: teamsters - The Indian Agent noted that many Paiutes worked in farming, freighting, herding. [CIA, 1881:130] 
1881 Shoshones: Nevada: employment - The Indian Agent reported that Shoshone labor was sought for by the ranchers and by many of the miners "in preference." [CIA, 1881:133]

1881 Native Americans: Amargosa Valley: hostilities between Native Americans and Euroamericans - Two "badmen" named Rockwell and Tex murdered a Native American family in the Amargosa Valley. Only a small boy survived. After caching extra horses and rifles at Lida's Little Mill, the two men staged a holdup at Chiatovich's store near Silver Peak. Antone Babcock shot one of their horses and the men fled riding double. Bob Stewart of Little Mill cut them off from their extra horses and they fled south on foot. Three Native American people from Lida accompanied Bob Stewart in pursuit of the pair: these were Shakespeare, Black Montezuma Dick, and Butcher Jake. The killers were finally killed "in the vicinity of a huge Medicine Rock held sacred by the Indians for ceremonial purposes." [Cook, nd:18]

1882 Native Americans: Pahranagat: agriculture: hostilities between Native Americans and Euroamericans - According to a newspaper report, "[i]t seems that a party of old Indians were engaged in farming, on their own account, a small plot of ground on the lower end of the ranch owned by Mr. Sharp. A man named Frenchy, living near, owned stock that naturally encroached on the growing crop, and the Indians were constantly compelled to herd them off. Mr. Frenchy, it appears, became indignant...and one day followed a venerable warrior to his wickiup and shot him dead...." ["Another from Pahranagat," Pioche Weekly Record, vol. 24, no. 19, July 22, 1882, p. 3, col. 3]

1882 Resting Springs: intermarriages between Native Americans and Euroamericans Philander Lee reportedly settled at Resting Springs about 1882, and was married to an Indian woman, as was his brother Leander. The two are credited with discovering the Lila C. colemanite mine. [Brooks, 1970:38]

1882 Paiutes: Nevada: employment - The Indian Agent noted that Paiutes were working for Euroamericans in "nearly every department of labor" and were willing to work hard. He stated that at least half the men could speak English well enough to be understood in work situations. Many lived off-reservation and "get their living by working for whites, appearing no different but in color from white laborers." [CIA, 1882:127]

1882 Shoshones: Nevada: residence in towns - The Indian Agent urged that Indian people be removed from the railroad and mining towns because of the evil influences there. "They congregate around small railroad and mining towns." [CIA, 1882:129]

1883 Native Americans: Pahrump - Charles Bennett had a homestead in Pahrump Valley "with the Paiutes only for neighbors, unless, indeed, the scattered white Arabs of the desert - renegade whites and squaw wives - and one or two white families, who lived at springs, from twenty to 100 miles away, could be called neighbors." Bennett furnished supplies to prospectors and traded with the Indian people. [Spears, 1892:86-87]

1883 Pioche: Native Americans: railroad travel - A newspaper refers to "[t]he Indian known as Railroad Jim, owing to his always being on the train when the cars are running..." [Pioche Weekly Record, vol. 26, no. 1, March 17, 1883] 
1883 Paiutes: Muddy River: disease - "The measles are scourging the Muddy [River]. Settlers and the Indians are dying off." [Pioche Weekly Record, vol. 25, no. 19, January 20, 1883, p. 2, col. 3]

1883 Navajo: Pioche: commerce - A local newspaper reported the presence of a Navajo Indian trader in Pioche, selling Navajo blankets to the local Indian people. [Pioche Weekly Record, vol. 27, no. 4, October 6, 1883, p. 2, col. 2]

1883 Timber Mountain: mining activities - Silver was discovered in the Timber Mountain Range. "Al Jones, of Little Cherry Creek, Nye county, who has been traveling considerable to and fro between his ranch and Pioche within the last year, reported the finding of rich float about fifty miles from Pioche, in what is called the 'Timber Mountain Range.' Some three weeks or so ago Hall Gear, at the request of Jones, went out there and prospected a little. While there he uncovered a ledge...W.H. Newton...left for the new field. At Bristol A.C. House, C. Quiliei, Grant Porter and Al Jones, all joined him...." ["New Mines Discovered," Pioche Daily Record, vol. 26, no. 14 , June 16,1883 , p. 3 , col. 1]

1883 Native Americans: Pioche: camp: employment: woodcutters: pinyon nuts - The Pioche newspaper reported that "[q]uite a number of Indians are camped close to our village." About 60 Native American people had retumed to town after gathering pinyon nuts in the mountains for about five weeks. "During that time Piochers had to cut their own wood." [Pioche Weekly Record, vol. 27, no. 7, October 27, 1883, p. 3, col. 2]

1883 Native Americans: Bullionville: sporting events: hostilities between Native Americans and Euroamericans - "[L]ast Friday was a gala day in Bullionville and one to be pleasantly remembered, if it were not for the shocking tragedy that took place in the evening, close to town, when an intoxicated Indian, after killing a dog, and shattering John Hearty's leg with a bullet, met his death at the hands of infuriated citizens. A large number of racemen, with their ponies, but (sic) in an appearance in the moming, and matches were made and run till evening...There were quite a number of Indians present also, and they two (sic) seemed imbued with the fun, betting their money freely on their favorite steeds..." [local news column, Pioche Weekly Record, vol. 26, no. 4, April 7, 1883, p. 2, col. 2]

1883 Native Americans: Bullionville: Moapa: regional political organization: relations between Native Americans and Euroamericans: Indian runners - "In a conversation with the Chief of the Muddy Indians on Tuesday, he said that his people did not want to have any trouble with the whites, and that he would not have been here at present if it were not for the Indian runners from the Rancheria near Panaca, who reported to his people that the Bullionville people were going to exterminate the last one of them." [local news column, Pioche Weekly Record, vol. 26, no. 5, April 14,1883 , p. 2, col. 2]

1883 Native Americans: Highland: pinyon nuts: horse thefts - "There are parties at Highland, hid in the mountains, stealing horses. It is probably the Indians, who are now out there gathering pine-nuts. The Indians, like many of their white brothers, have a great weakness for horseflesh." [local news column, Pioche Weekly Record, vol. 27, no. 2, September 22, 1883, p. 2, col. 2] 
1884 Native Americans: Pioche: Bullionville: Panaca: dance - "Several Pioche Indians, with the belle of the campoody, indulged in a protracted war dance Tuesday evening, on the road between Panaca and Bullionville." [local news column, Pioche Weekly Record, vol. 27, no. 18, January 12, 1884, p. 2, col. 2]

\section{5-89}

1886 Native Americans: Oasis Valley: camps - At the Scott ranch in Oasis Valley, Brooks climbed a craggy mountain behind the springs and found thirteen large "dens...which would accommodate two or three hundred Indians." "In some of these dens I found Indian stores, baskets, and broken crockery." [Brooks, 1970:18$19,41]$

1887 Paiutes: Nevada: population - The Indian Agent estimated the Paiute population at 4,500, with 425 living on the Walker River reservation, 469 on the Pyramid Lake reservation, and the majority living off-reservation. [CIA, 1887:162]

1887 Paiutes: Nevada: employment - The Indian Agent reported that several hundred Paiutes were working on farms and in salt, soda, and borax marshes. [ClA, 1887:162]

1889 Paiutes: Pyramid Lake: disease - "Pneumonia has proved fatal in many cases among the Paiutes on the Pyramid Lake Reservation, due to the fact that the Indians refuse to have any person except their own 'medicine men' prescribe for them." [Pioche Weekly Record, vol. 27, no. 17, July 6, 1889, inside p. 4]

1889 Native Americans: Panaca: fandango: regional links - The Biggest Indian fandango of the season ended last Saturday night at Panaca. It was in progress for five or six nights during which time dancing was kept up pretty steadily, ending with great ceremonies on Saturday. Between 200 and 300 Indians were assembled, a number coming in from Cedar and Parowan, Utah....The Indians from St. George and the neighboring settlements of Southern Utah and from all over this country spent five nights last week in dancing eating, and engaging in a general fandango." [local news column, Panaca Items, Pioche Weekly Record, vol. 37, no. 6 , April 20,1889 , p. 3, col. 1, 3]

1889 Native Americans: Pioche: fandango - "Bucks and squaws were at a premium for housework during the fandango last week." [local news column, Pioche Weekly Record, vol. 37, no. 6, April 20, 1889, p. 3, col. 1]

1889 Paiutes: Mason Valley: dance: regional links - The Paiutes of Mason Valley had a big rain dance last week. The big man who formerly brought rain when they desired it, died last Summer, and therefore they have taken it upon themselves to pray for rain in their peculiar manner. If rain does not come soon there will be another big dance at the Walker Lake Reservation on which occasion the Paiutes from all over the country will be notified to be present." [Pioche Weekly Record, vol. 37 , no. 8 , May 4,1889, p. 3, col. 4]

1889 Native Americans: Panaca: fandango - "Another Indian Fandango was in progress at Panaca Thursday. The Indians seem to have been on a spree for two or three months past." [local news column, Pioche Weekly Record, vol. 37, no. 11, May 25, 1889 , p. 3, col. 2] 
1889 Native Americans: Pioche: pow-wow: regional links - "The Indians have just finished another five days and nights pow-wow. This time there were Indians from the Northem part of the State." [local news column, Pioche Weekly Record, vol. 37 , no. 16 , June 29,1889 , p. 3, col. 3]

1889 Native American: Pioche: pow-wow: regional links - "Last Sunday night the Indians finished another prolonged pow wow. It was reported that about 200 Indians were gathered from the surrounding country; many of them were from Cedar City, Utah, and others from the remote parts of this State. Pine nuts formed their general bill of fare." [local news column, Pioche Weekly Record, vol. 38, no. 1, September 21, 1889, p. 3, col. 3]

1889 Native Americans: Pioche: pow-wow - "The Indians are gathering in from the neighboring settlements and town preparatory for a general Christmas powwow. The Indians here are making improvements on the dancing grounds so they will be in good condition for the occasion." [local news column, Pioche Weekly Record, vol. 38, no. 14, December 21, 1889, inside p. 4, col. 3]

1889 Pioche: Hawthorne: Austin: disease - "A good many of our citizens have been down with a sort of distemper....Seven cases of pneumonia are reported in Hawthorne, Nevada....Austin is afflicted with an epidemic of typhoid-pneumonia, with fatal results, three deaths occurring last week." [local state news, Pioche Weekly Record, vol. 37, no. 6, April 20, 1889, p. 3, col. 1, 4]

1880s Paiutes: Oasis Valley: intermarriage of Native Americans and Euroamericans: interactions between Native Americans and Euroamericans - Philip Earl, of the Nevada Historical Society, writes that Montillion Murray Beatty arrived in the Oasis Valley in the late 1800s. Reportedly Beatty "wandered in off the desert one day with all his worldly goods packed on two burros. The Paiutes took him in with every expectation that he would remain among them only until he rested...but...he showed no inclination to depart. After some weeks, the Indians held a meeting to discuss their paleface guest and decided to ask him to leave...but he lingered on. The Indians then decided to kill him, but he had at least one staunch defender, Mahanagos, the daughter of their leader. It was apparently for her sake that Beatty tarnied, and she had given him to understand that he had found favor in her eyes also....one night, the Paiutes held another conference and decided to dispatch him to the hereafter....Mahanagos, meaning 'spring of the desert' in English, came to his defense and his life was spared, but only on the condition that he marry her. Beatty was willing and the wedding took place a few days later. Montillion Beatty settled in with his bride, gave up his dreams of mineral wealth and became for all intents and purposes an Indian," though the development of Beatty on what had been Beatty's ranch made him fairly prosperous. (Beatty's wife Mahanogos was called Maude by Euroamericans.) [Earl, 1986:10-13]

1880s Paiutes: Spring Mountains: water resources: relations between Native Americans and Euroamericans - "Pahutes denied the Mt. Potosi miners the use of any water from Mountain Springs" when mining operations were begun in that area by the Yellow Pine Mining Company, whose owners included the Yount family. As a result, water had to be hauled from Blue Diamond. [Lynch, 1979:69]

\section{0-91}

1890 Nye County: population - According to the 1890 census, Nevada had a total population of 45,761 and a total Native American population of $5,156,3,604$ of 
them living off-reservation. Nye County had a total population of 1,290 (down from 1,875 in 1880) and a Native American population of 414 . (The detailed enumeration for Nye County does not enumerate any Native Americans for southern Nye County, though this clearly does not mean there were no Native Americans there.) [Department of the Interior, Census Office, 1891:2,381,395; Department of Commerce and Labor, Bureau of the Census, 1910:86]

1890 Oasis Valley: Euroamerican settlers - Jack Longstreet took a 160-acre homestead just north of the later site of Beatty. According to Deputy Nichol, he had 28 cattle and 18 horses. [Zanjani, 1988:49]

1890 Shoshones: Nevada: fandangos - The Indian Agent reported that the Shoshones customarily have four fandangos a year, all moving to a common camp and singing and dancing and gambling. "Fandangos are both social and religious in character." [CIA, 1890:151j

1890 Native Americans: Pioche: commerce - "Young mocking birds are plentiful in town, the Indians bringing them in and selling them for two bits apiece." [local news column, Pioche Weekly News, vol. 39, no. 18, July 19, 1890, p. 3, col. 1]

1890 Native Americans: Panaca: pow-wow: regional ties - "During the week the Indians have had their annual pow wow at Panaca. The Indians gathered from all over the county and some were from Utah." [local news column, Pioche Weekly Record, vol. 40 , no. 11 , November 29,1890, p. 3, col. 2]

1890 Paiutes: Shoshones: Belmont: Reese Valley: militance: relations between Native Americans and Euroamericans: relations between Paiutes and Shoshone - "The Belmont Courier says: News was received at Belmont on Tuesday evening last that a band of Paiute Indians were on the warpath in Reese River Valley and that 300 Shoshones had pitched their tents in Raycrott Canyon near Belmont. A number of citizens immediately armed themselves and patrolled the town all night...The next day it was ascertained that the Indians in Roycroft Canyon had no intention of attacking the whites, but, on the contrary, Captain John, commonly known by the sobriquet of Whiskey Johnny, informed several citizens that should the Paiutes attempt to interfere with the whites, the Shoshones would join the citizens in downing the Paiutes. Naches on the Indian Scare. The Virginia Chronicle says: Chief Naches of the Paiutes thinks the reported hostile Indian uprising in Nye county and further east does not amount to much.... The Paiutes, he says will live and die with the whites, and in case of war will help them. Naches has judiciously gone over to consult with the military heads of the Pacific Coast Division to ally their fears." ["The Nye County Indian Trouble," "Naches on the Indian Scare," Pioche Weekly Record, vol. 40, no. 11, November 29, 1890, p. 3, col. 2]

1890 Pioche: disease - "Nearly everybody in town has a cold or something akin to 'la gripp'(sic). It's a mixture of Influenza, sneezerine and cougherine." [local news column, Pioche Weekly Record, vol. 38, no. 22, February 15, 1890, p. 3, col. 3]

1890 Pioche: disease - "The sickness that has been prevalent in our midst for the last couple of months still holds its sway, and several of our citizens are seriously indisposed." [local news column, Pioche Weekly Record, vol. 40, no. 11, November 29,1890, p. 3, col. 2] 
1890s Oasis Valley: Euroamerican settlers: intermarriage of Native Americans and Euroamericans - Ralph J. Fairbanks, one of the earliest white settlers in the Amargosa region, reminisced that when he first settled in the Ash Meadows area there were only five white men around, all of them "on the dodge for something," and most of them married to Native American women. [Zanjani, 1988:53]

1890s Paiutes: Death Valley area: impacts on wild foods: interactions between Native Americans and Euroamericans - "The Paiutes...look with disfavor on the cutters of nut-pine, but are calmly indifferent to acts of the mesquite-wood miners." (Both trees were cut for fuelwood.) "Both trees produce seeds much prized as Paiute food." [Spears, 1892:119]

1890 s Johnnie district: mining activities - Several ore discoveries were made by a party from Indian Springs. [Kral, 1951:86]

1890s Pahrump: outlaws - The citizens of Pioche during the 1890 s tolerated a nationwide reputation for casual gunplay and epic political corruption, but they drew the line at horsetheft. For years, Pioche had been victimized by the loss of valuable horses and cattle. The Lincoln County Record blamed the rustling on 'the lawless element who now infest the interior of the county between California and Nevada and where no law now exists.' This meant Pahrump Valley...Piochers were convinced that most of the stolen animals were going to Pahrump....in March of 1892, when one of the Pioche mining companies lost its entire string of horses and mules, [Sheriff] Rives and two deputies set out to track the stolen herd.... The posse moved on to the Evans ranch on the Amargosa River. W.P. Yount, a leading Pahrump rancher who had joined the posse...returned to report that the stolen stock was in the corral....suspects were hauled to Pahrump the next day..." The prisoners, Charles McCannon and Charles Wilkinson, escaped to a ranch at Resting Springs. They were again taken into custody. "Surprisingly, the court heard all the evidence and ruled the facts were insufficient to justify a verdict of guilty, although they had been caught with the stolen stock....Things returned to normal quickly. Pioche horseflesh still had a tendency to stray toward Pahrump and the California border. The honest ranchers of Pahrump continued to act as recipients of stock with questionable bills of sale..." ["In Old Nevada," Pahrump Valley's Horse Thieves," Nevada State Joumal, March 7, 1976, p. 10, col. 1]

1890 Johnnie district: mining activities - The Johnnie mine was worked from 1890-95. There was placer mining on the slopes below the Congress mine. [Kral, 1951:86]

1890-91 Native Americans: Independence: Palmetto: Sylvania: Ghost Dance - According to Zanjani, in the winter of 1890-91 there was a very large Ghost Dance near Independence with at least 300 "braves" participating. Another large Ghost Dance was held in the Smoky Valley and the governor sent rifles and ammunition to Belmont. On January 4, a Ghost Dance was held on the crest of the White Mountains in western Esmeralda County. Native Americans from the Sylvania area joumeyed to the dance, as did Jack Longstreet, who ran a tent saloon in Sylvania at the time. Jack Longstreet apparently persuaded the Native American people employed in Sylvania to proceed from the Ghost Dance and take direct action upon the superintendent of the Sylvania Mining Company. Superintendent Robert Starrett had refused to pay Native American employees in cash or checks, forcing them to trade in scrip at extremely unfavorable exchange with local merchants. Jack 
Longstreet and Ross Edwards led a crowd of Indians to the Sylvania mine (just across the California border). Starrett was severely beaten by the party until he agreed to make out large checks to all the men. Liquor was also taken. After this, the Ghost Dance was resumed. The next day, Starrett swore out warrants against Longstreet, Edwards, and several Native Americans. [Zanjani, 1987:47-48; Zanjani, 1988:55-56]

1891 Native Americans: Sylvania: Palmetto: Ghost Dance: mineworkers: hostilities between Native Americans and Euroamericans: other tribes - A Ghost Dance was held near the Palmetto mine on the California side of the California/Nevada border. Several Sioux Indians participated. The day after the dance, a crowd left the dance together, traveling first to a cabin near the state line inhabited by a man named Murphy. There they hoped to obtain liquor. Murphy drove them off with gunfire, and the party traveled on to the Sylvania mine on the Nevada side. The party included and reportedly led by Jack Longstreet and Ross Edwards, both of whom had Native American wives. The crowd administered a beating to the Superintendent of the Sylvania mine and forced him to write paychecks to the Native American men. There was a longstanding issue between Native American laborers at the Sylvania mine and Superintendent Robert Starrett, who paid the men in scrip that could only be cashed by agents of the mine, apparently in San Francisco. Superintendent Starrett later swore out warrants in Inyo County for Edwards, Longstreet, and several Shoshone and Paiute men. Euroamerican miners in Tule Canyon organized to "bring the Paiutes to their senses." ["We Have the Ghost Dance," San Francisco Examiner, vol. LII, January 11, 1891, p. 4, col. 1]

1891 Native Americans: Ash Meadows: Native American prospecting: Black family Bob Black, Ash Meadows Native American, was "a prospector of some ability." "The rich ledges uncovered south of Ivanpah at Vanderbilt in 1891 were Black's discovery, although he received virtually nothing for his pains." $\mathrm{He}$ also contributed to mineral discoveries at Greenwater. [Zanjani, 1988:114]

1891 Native Americans: Ash Meadows: agriculture: water resources: Ash Meadows Charley - "In former times, it [Ash Meadows] has been something of a place, judging from the ruins of houses and deserted ranches....At present there are but three small ranches which are owned respectively by George Walkins, John Howell and Indian Charley....The most singular feature of the Meadows, however, is the numerous large springs, which make a portion of the country a veritable oasis in the desert...Some of these springs are very large and strong, discharging from $5 \mathrm{cs}$ to 600 inches...and some of them boil up with such force that a person attempting to dive into them is driven back by the current." ["Ash Meadows and the Great Amargosa and Ralston Deserts," Belmont Courier, vol. 18, no. 19, June 13, 1891, p. 2, col. 3-6]

1891 Native Americans: Pahrump: employment: gunmen - Jack Longstreet, Phil Foote, and several Native Americans were apparently among the hired gunmen on the "MacArthur side" of a dispute at the Johnnie mine in Pahrump Valley, a mine held by a Mormon group headed by a man named Langford. There was a gun battle between this group and gunmen working for the Mormon mine owners, resulting in the death of Phil Foote and the wounding of several Indians. [Lewis, 1969:5] 
1891 Native Americans: Muddy River: Ghost Dance: regional links - "John Roeder, who returned last Tuesday from the Muddy Valley 150 miles south of here...reports the Indians from this whole section of country to be congregating there. The Indians in the valley made frequent inquiries of him as to whether Indians from this vicinity were on their way down or not. On his return he met squad after squad going south. The recent Indian troubles in the east, and Messiah craze in the northern part of this State are supposed to be the causes of the unrest among the Indians of this section. They are peaceful but their present movements alarm settlers of the Muddy and a request for State arms may be made. The Wallapai Indians frequenting Mineral Park, in Arizona just over the line left that town some weeks ago, the squaws in leaving saying to some of the white women, 'Squaw long time wash for white woman, pretty soon white woman wash for squaw' and since then have tried to induce the Mohave tribe further down the river to join them and go on the war path. So far their efforts have failed but our Muddy settlers fear overtures from the Wallapis to the Indians now gathering there and want to be prepared to fight if necessary..." ["Moving Indians," Pioche Weekly Record, vol. 40, no. 17, January 10, 1891, p. 3, col. 3]

1891 Pioche: disease - "The malady, la grippe, which made its first appearance here two weeks ago yesterday, has since that time swept the whole town and surrounding country. Fully 90 per cent. of the population here have been affected by it, and five deaths have thus far resulted. It appears in several forms....In those cases which terminated fatally the disease developed into pneumonia....The question still is, not who is sick, but who is well..." ["A Sick Town," Pioche Weekly Record, vol. 40, no. 24, February 26, 1891, p. 3, col. 2]

1891 Native Americans: Pioche: camp - "Too much fire-water among the Indians camped south of town caused a rumpus among them last Thursday night.... We doubt if anywhere in the State the law against selling whiskey to Indians is held in such contempt as here..." [local news column, Pioche Weekly Record, vol. 40, no. 28, March 26, 1891, inside p. 4, col. 2]

1891 Native Americans: Pioche: disease - "Since la grippe has been so prevalent here our usual quota of Indians appear to have given it a wide latitude, and but few are to be seen on our streets. They underwent the ordeal and seem afraid to return." [local news column, Pioche Weekly Record, vol. 40, no. 32, April 23, 1891, p. 3, col. 2]

1891 Native Americans: Pioche: commerce - "Our Indians are making rapid strides in civilization. All their small change goes in the purchasing of oranges." [Pioche Weekly Record, vol. 40, no. 34, May 11, 1891, inside p. 4]

1891 Native Americans: Pioche: Fourth of July - In the announcement of the order of the Fourth of July parade, Item 13, the last, is "Aborigines." ["The Fourth: Order of Exercises," Pioche Weekly Record, vol. 40, no. 40, June 25, 1891, inside p.]

1891 Native Americans: Pioche: Fourth of July - "The procession on the Fourth was one to be long remembered.... The wives of the noble reds took a prominent part and appeared to appreciate the honor of the occasion even more than the spectators." ["The Fourth's Observance," Pioche Weekly Record, vol. 40, no. 42, July 9, 1891, inside p.] 
1891 Native Americans: Pioche: pow-wow - "Of late the Indians hold a big powwow every Sunday afternoon, on the highhill northeast of town, and spend the time in gambling accompanied by singing, which attracts large numbers of visitors." [Pioche Weekly Record, vol. 41, no. 7, October 29, 1891, inside p. 4, col. 1]

1891 Johnnie: mining activities - Gold was discovered near Johnnie in 1891. [Kensier, nd: $11-217]$

1891 Johnnie: town - Gold was discovered on the northwestern slopes of the Spring Mountains in winter 1891 and a rush ensued. The area was called the Montgomery district. By May 1891, there was a camp with over 100 inhabitants. By 1893, the boom had turned to bust, but the camp revived in 1898. [Paher, 1970:324]

1891 Pahrump: mining activities - "[N]ew mines in the Southern part of Nye county.... were discovered early last Winter by George Montgomery....In the northwest end of the Washington Mountains, which skirt one side of the Pahrump Valley, the party discovered gold bearing quartz....A new district, named Montgomery in honor of the discoverer, has been organized, and when Mr. Glass left there were about 100 men and one woman in the camp....Nut pine timber, good for fuel, is abundant within four or five miles.... Much of the agricultural land in Pahrump Valley has been taken up by Californians under the land laws of Nevada, but there is plenty of timber land to be had at the Government price, $\$ 1.25$ per acre." ["The Pahrump Mines," Daily Nevada State Journal, vol. 37, no. 28, May 1, 1891, p. 2, col. 3]

1891 Pahrump: mining activities - "Thhe North Belle mine, which is owned by the Yount brothers...is located three miles north of the Chispa [owned by Montgomery]." ["The Montgomery Mines," Daily Nevada State Journal, vol. 37, no. 58, June 5, 1891, p. 3, col. 2]

1891 Native Americans: Death Valley: Panamint Valley: agriculture - Botanist Vernon Coville, member of the 1891 Death Valley expedition, saw about 25 Panamint Indians living on the west side of the valley. "At the mouth of Hall canon, near Hot springs, at the west foot of the Panamint mountains, and in Johnson Canyon, on the eastern or Death Valley slope of the same range, the Indians have under crude irrigation and cultivation two or three acres of ground. The crops commonly raised are corn, potatoes, squashes, and watermelons...." [Greene, 1981:364]

1891 Native Americans: Death Valley area: agriculture: mine workers - In Saline Valley the Native American village had "about one hundred acres of land enclosed, and some of it planted in alfalfa... The alfalfa barley, and wheat raised they sell readily to the Borax Company, whose borax works are located less than a mile from the Indian village. This company pays the Indians a small royalty for the use of water during the irrigating season... On the east side of the Panamint mountains, at a place marked "Johnson's $R$, ... a couple of families... [are] raising corn, melons, squashes, and a few peaches and grapes...All told, these Indians IPanamint and Saline Valley] must number less than one hundred. The men are very fair workers and find employment at times about the mining camps of Panamint, Darwin, and elsewhere." [Nelson, 1891:372] 
1891 Paiutes: Death Valley area: hunting - When "Paiutes" began building sheephunting blinds along the ridges around Death Valley in fall 1891, prospectors in the area "jumped to the conclusion that the Indian people were building forts to guard mines of fabulous wealth, and for a general attack on the white navigators of the desert." [Spears, 1982:73]

1891 Other tribes: Nevada - "Many Indians from distant tribes have been here to see him [Wovoka] and are now visiting him, and from eighty to a hundred have been here to see him during the past six months." (CIA, 1891:301) [Wovoka was the Prophet of the Ghost Dance, which spread to Indian peoples all over the West in the early 1890s. Wovoka lived at Pyramid Lake, and Indians came from all over the country to hear his prophecies and teachings first hand (Knack and Stewart, 1984:120-21)]

1891 Paiutes: Northern Nevada: fandangos - The Indian Agent reported that the fandangos during 1890 "took a religious turn," inspired by Jack Wilson. [CIA, 1891:304]

\section{2-99}

1892 Paiutes: Shoshones: Ash Meadows: settlement - Coville wrote that "[a]mong the mixed Paiutes and Shoshonis at Ash Meadows, Nevada, was seen a very broad, shallow, flat bottomed kind of bowl..." [Coville, 1892:359]

1892 Paiutes: Spring Mountains: plant harvesting - Coville wrote that "[i]n some parts of the Charleston mountains, Nevada, the Paiutes use a small mescal plant, Agave utahensis, which grows there in great abundance. Near the summit of Mountain Spring pass...some of the hillsides are almost covered with the plant, and in suitable places near by are the holes where in previous years mescal has been cooked." [Coville, 1892:356]

1893 Johnnie district: mining activities - George M. Montgomery discovered the Congress mines in the Johnnie district. M.B. Bartlett, a later owner, believed these to be the "lost Breyfogle mines" (see entry for late 1860s). [Tonopah Mining Reporter, vol. 4, no. 3, September 20, 1924, p. 2, col. 4]

1894 Oasis Valley: agriculture - M.M. Beatty and John Howell (a black man) settled at the ranch later known as Beatty ranch in 1894. [Tonopah Miner, vol. 4, no. 5, July 15, 1905, p. 6, col. 4]

1895 Paiutes: Ash Meadows: Native American prospecting: Bob Black: Mary Scott Mary Scott, an Ash Meadows Shoshone woman, discovered some gold float on a hunting trip in the Black Mountains east of Death Valley. She showed it to Bob Black, an Ash Meadows Paiute man, who paid her twelve bottles of wine for the information. Black then sold the site of the Confidence mine to Frank Cole and James Ashdown for $\$ 4,000$. Black never received the money. The mine proved unprofitable and the investors refused to pay Black and other creditors. The following year, a new supervisor was sent to try to make the mine profitable and cut off Black's access to supplies at the company store, which George Montgomery had permitted Black to draw in lieu of the substantial payment owed to Black for the discovery. The superintendent was shot and Black was under suspicion though never charged. Black had hoped to buy Longstreet's Ash Meadows ranch with the $\$ 4,000$ he never received. [Zanjani, 1988:114-115] 
1895 Paiute: Shoshone: Pioche: settlement - "The Indian wickiup in the vicinity of the smelter below town, was the scene of a rather cold blooded killing last Friday night. Mustache Charley, a Paiute, who has been around town here for a number of years, and is well known, was shot dead by 'Bob' another Indian, a Shoshone, with a Winchester rifle..." ["Shot Dead," Pioche Weekly Record, vol. 45, no. 11, December 5, 1895, p. 4, col. 3]

1895 Paiute: Shoshone: Pioche: murder: political leadership: relations between Paiutes and Shoshones - Settling the murder of Mustache Charley involved "several lengthy interviews over the telephone with Duck Creek Charley, the Shoshone Chief heading matters from this end, and Cowich Bill, Chief of the Paiute's speaking from Delamar..." ["A Buckboard and Harness," Pioche Weekly Record, vol. 45, no. 12, December 12, 1895, p. 4, col. 3]

1896 Paiute: Oasis Valley: intermarriage of Native Americans and Euroamericans: M.M. Beatty, Jr. - M.M. Beatty, Jr., stated that he was born in 1896, one of three children of a union between M.M. Beatty, Sr., and his wife Jane. M.M. Beatty, Jr., identified his mother as a full-blooded Paiute born in the vicinity of Death Valley. [Taped interview with M.M. Beatty, Jr., November 1, 1968, Nevada Historical Society]

1896 Native Americans: Death Valley: agriculture - In Johnson Canyon, "just over the summit, and southeast of Panamint, was 'Johnson's garden' in the flush days of the rise and before the fall of Panamint. Here Indians Pete and George are cultivating four or five acres of land." Their crops included alfalfa, grapes, beans, corn, and wheat. [Greene, 1981:364]

1896 Paiutes: Pioche: Panaca: murder - "Railroad Jim, the mechanical genius of the Paiute tribe of Indians which frequents this [Pioche area] and the Panaca vicinity, will no more follow his vocation of painting, roofing, farming, or drinking bad whiskey." He was killed by his brother after going to the Indian camp near Panaca and threatening various relatives there. ["Riddled with Bullets," Pioche Weekly Record, vol. 45, no. 24, March 5, 1896, p. 4, col. 2]

1897 Native Americans: Panamint region: agriculture - An Indian farm known as Panamint Tom's place was located in Anvil Canyon. When W.J. Langdon visited it in 1897, there were eleven Indian people on the ranch. [Greene, 1981:365]

1897 Native Americans: Nevada: commerce: pinyon nuts - "Over 1,000 sacks of pine nuts weighing 75,000 pounds have been shipped from Carson this season, and not half of the crop gathered has yet reached there." [Belmont Courier, vol. 14, no. 46, December 10, 1897, p. 3, col. 1]

1897 Paiutes: Walker Lake area: employment: agriculture - The Indian Agent said the Paiutes paid more attention to securing work in the adjoining valleys than to caring for their crops: "T]hey commonly arrange these so that they will not mature at the same time as those of the ranchers near, that they may secure work from these ranchers." [CIA, 1897:188]

1897 Panamint region: mining town - The town of Ballarat became prominent around 1897. The main mine, the Radcliffe, produced from 1898 to 1903. [Greene, $1981: 30]$ 
1899 Native Americans: Belmont: residence in town: pow-wow - "A crowd of drunken Indians created great excitement in Belmont on Monday last. A number of bucks had been rabbit hunting and concluded on their return to celebrate the successful hunt by holding a feast and Indian Tim's house was selected as the place for the pow-wow....about six o'clock the residents in the northem part of town were frightened by the loud talking of the excited Indians. Several white men went to stop the disturbance..." Several Native Americans were arrested. "This disturbance is only one of many which have occurred in Belmont recently and from present indications it will not be the last. The hills are being covered with Indian houses, which are occupied by 'smart' young Indians, who consider themselves as good as the whites, being led to this conclusion by the familiar way in which they are treated by white men..." ["Local Jots," Belmont Courier, vol. 26, no. 46, December 9, 1899, p. 2, col. 2]

1890s Shoshones: Oasis Valley: intermarriage of Native Americans and Euroamericans Several Euroamerican ranchers who settled in Oasis Valley in the late nineteenth century married Shoshone women. [Lingenfelter, 1986:21]

1890s Paiutes: Oasis Valley area: intermarriage of Native Americans and Euroamericans - M.M. Beatty lived with a full-blood Shoshone wife named Jane. They had four children. [Weight and Weight, 1980:13-17]

1890s Native Americans: Ash Meadows: camps: Black family - Jack Longstreet lived at Ash Meadows in the 1890s, until 1899. Zanjani states that there were two Native American camps near Longstreet's ranch, "one at the hill behind his cabin and the other farther northeast at Point of Rocks; both were linked to the Meadows by trails. Longstreet was undoubtedly acquainted with the Blacks, an Indian family in the Meadows. One of the Black women later married his good friend and drinking partner Albert Howell, a half-breed and an impecunious rancher. He surely knew the shadowy and dangerous Bob Black and once came near selling his ranch to the Indian. Bob's sister Fannie would also have been a familiar face to him." [Longstreet later married Fannie Black.] While living in Ash Meadows, Longstreet lived with a Native American woman named Susie, marrying Fannie after he moved away from Ash Meadows. After moving from Ash Meadows to the Kawich Range, Longstreet "kept close ties to the Death Valley area. Not only did he continue to prospect here, but he also came back occasionally to Ash Meadows for a few days of drinking, gambling, and general roistering with his old Indian friends. Another factor that kept Longstreet linked to this region was his wife, Fannie Black, who was an Ash Meadows Paiute." [Zanjani, 1988:76-78,109; Zanjani, 1987:49-50]

1890s Native Americans: Death Valley region: prospecting - Panamint Tom reportedly guided Julius Goldsmith to a rich mine in Pleasant Canyon. Hungry Bill was reported to have found gold and silver near Panamint City long before whites did. The Nellie mine near the Indian Ranch in Johnson Canyon apparently was located by Tim Billson, the son of Hungry Bill. [Greene, 1981:371]

1890s Shoshones: Tule Canyon: mine workers - Most of the placer miners in Tule Canyon during the 1870 s were Mexicans; in the 1880s, most were Chinese; and in the 1890s, they were a mix of Euroamericans, Chinese, and Shoshones. [Lingenfelter, 1986:111] 
1890s Southern Paiutes: Ghost Dance - Paiute groups affected by the Ghost Dance included Las Vegas, Moapa, Panaca, and Pahranagat. [Kelly and Fowler, 1986:384]

1890s Paiutes: Rhodes Salt Marsh: mine workers - At Rhodes Salt Marsh, owned by the Nevada Salt and Borax Company and located about eight miles from the later site of Mina, some 125 Paiutes were employed to dig clay, women as well as men. [Spears, 1892:126]

\section{Post-Contact Period Since 1900}

\section{0-04}

1900 Nye County. Native Americans: population - According to the 1900 census, the total population of Nevada was 42,335 . The population of Nye County was 1,140 and the Native American population of Nye County was 372. In the 1900 census, Pahrump is the only precinct listed in southern Nevada. It evidently encompassed all of southern Nye County, including Ash Meadows and the Oasis Valley as well as Pahrump Valley, since some of the individuals and families enumerated in the Pahrump precinct are identified in other sources as living in Ash Meadows or in the Oasis Valley area.

The census of Pahrump precinct for 1900 enumerated a total of 107 persons, 74 of them identified as full-blood Indians, and three as children of a white father and an Indian mother of an unidentified tribe from North Carolina.

The 1900 census was the first with a detailed enumeration of Native American people in southern Nye County, including individual names, tribal affiliations, tribal affiliations of parents, occupations, and information about housing (whether an individual owned a house or land), and language.

Of the full-blood Native Americans enumerated for Pahrump precinct, 39 persons were identified as Shoshone and 34 as Paiute. Of those listed as Paiute, four had a Paiute father and a Shoshone mother. Listed occupations included cook (1), common laborer (3), farm laborer (2), gardener (2), irrigator (2), teamster (1), washer (1), and "none" or blank (62). Among those with occupations listed as "none" was Chief Tecopa of Pahrump. For details, see Table 4. [Census Office, 1901a:264; Census Office, 1901b; Bureau of the Census, 1913:86]

1900s Shoshones: Oasis Valley: political organization: Panamint Joe Stuart - The last pakwinavi of the Oasis Valley people was Panamint Joe Stuart [Lingenfelter, 1986:21]

1901 Disease: Lincoln County - "And now the smallpox has worked its way into Lincoln County..." ["Smallpox," Lincoln County Record, January 11, 1901, p. 2, col. 3]

1901 Native Americans: Pioche: employment - "The Indians are getting back to town and are being utilized [for] housework." [local news column, Lincoln County Record, October 25, 1901, p. 2, col. 1]

1902 Shoshones: Oasis Valley: Native American prospecting - Bob Montgomery employed Hungry Johnny, a Shoshone, to prospect for him. Montgomery met him at a ranch in Oasis Valley (north of Bullfrog). [Weight and Weight, 1980:27-28] 
Table 4. 1900 Census Data on Native American People in Pahrump Census Precinct (Encompassing All of Southern Nye County) ${ }^{a}$ (Page 1 of 3 )

\begin{tabular}{|c|c|c|c|c|c|c|c|}
\hline Name, Rel. to $\mathrm{HOH}$ & G A & $\begin{array}{l}\text { Mar } \\
\text { CY }\end{array}$ & $\begin{array}{l}\text { Child } \\
\text { D N }\end{array}$ & Occupation & $\begin{array}{l}\text { Language } \\
\text { RWS }\end{array}$ & $\begin{array}{l}\text { Economic } \\
\text { HXAT }\end{array}$ & $\begin{array}{l}\text { Ethnic } \\
\text { EF M }\end{array}$ \\
\hline Adobe JIm & $M, 60$ & $M, 16$ &,-- & Gardener & $N, N, N$ & $-, N, Y, N$ & $P, P, P$ \\
\hline Lamopitz, Wife & $F, 55$ & $M, 16$ & 4,2 & Washer & $N, N, N$ & $-, N, Y, N$ & $P, P, P$ \\
\hline Jicks, Dau & $\mathrm{F}, 15$ & $S,-$ &,-- & $\longrightarrow$ & $N, N, Y$ & $-, N, Y, N$ & $P, P, P$ \\
\hline Indlan Creek Ben & $M, 65$ & $M, 27$ & $\because-$ & Gardener & $N, N, Y$ & $-, N, Y, N$ & $P, P, F$ \\
\hline Jennie, Wife & $F, 60$ & $M, 27$ & 6,5 & None & $N, N, N$ & $-, N, Y, N$ & $\mathrm{~S}, \mathrm{~S}, \mathrm{~S}$ \\
\hline Wahmoritz, Dau & $F, 25$ & $M, 3$ & 2,1 & None & $N, N, Y$ & $-, \mathrm{N}, \mathrm{Y}, \mathrm{N}$ & $P, P, S$ \\
\hline Sam, Son & $M, 23$ & $S,-$ & $\because-$ & Laborer & $N, N, Y$ & $-, N,-, N$ & $P, P, S$ \\
\hline Fred, Son & $M, 13$ & $M, 1$ & $\therefore-$ & None & $N, N, Y$ & $-, \mathrm{N},-, \mathrm{N}$ & $P, P, S$ \\
\hline Ipatch, Son & $M, 3$ & $S_{1}-$ &,-- & None & $N, N, N$ & $-, N,-, N$ & $P, P, P$ \\
\hline George Roberts & $M, 70$ & $M, 17$ & $\because-$ & Laborer & $N, N, Y$ & $-, N,-, N$ & $P, P, P$ \\
\hline Sally, Wife & $F, 50$ & $M, 17$ & 2,1 & None & $N, N, N$ & $-, N,-, N$ & $P, P, P$ \\
\hline ?, Sister & $F, 60$ & $W,-$ & 3,0 & None & $N, N, N$ & $-, N,-, N$ & $P, P, P$ \\
\hline Pooyet, Nephew & $F, 75$ & $\mathbf{W},-$ & 2,2 & None & $N, N, N$ & $-, N,-, N$ & $P, P, P$ \\
\hline Mouse, Nephew & $M, 15$ & $S,-$ &,-- & None & $N, N, N$ & $-, \mathrm{N},-, \mathrm{N}$ & $P, P, P$ \\
\hline Sooner (?) & $M, 35$ & $M, 12$ & $\because-$ & Farm Labor & $N, N, Y$ & $-, \mathrm{N},-, \mathrm{N}$ & $P, P, P$ \\
\hline Nancy, Wife & $F, 30$ & $M, 12$ & 0,0 & None & $N, N, N$ & $-, N,-, N$ & $P, P, P$ \\
\hline Tecopa John & $M, 35$ & $M, 7$ &,-- & Farm Labor & $N, N, Y$ & $-, N,-, N$ & $P, P, P$ \\
\hline Crow, Wife & $\mathrm{F}, 30$ & $M, 7$ & 0,0 & None & $N, N, N$ & $-, N,-, N$ & $P, P, P$ \\
\hline Nana, Sister & $F, 10$ & $\mathrm{~S},-$ &,-- & None & $N, N, N$ & $-, N,-, N$ & $P, P, P$ \\
\hline Shoofly Jim & $M, 50$ & $M, 20$ & 0,0 & None & $N, N, N$ & $-, N, Y, N$ & S,S,S \\
\hline Shoofly, Wife & $F, 45$ & $M, 20$ & 0,0 & None & $\mathrm{N}, \mathrm{N}, \mathbf{N}$ & $-, \mathrm{N},-, \mathrm{N}$ & $S, S, S$ \\
\hline Mary, Sister & $F, 35$ & $w,-$ & $\because-$ & $?$ & $N, N, Y$ & $-, N,-, N$ & $S, S, S$ \\
\hline Charley Ashmeadow & $M, 55$ & $M, 28$ & $\therefore-$ & None & $N, N, N$ & $-, N,-, N$ & S,S,S \\
\hline Minnie, Wife & $\mathrm{F}, 40$ & $M, 28$ & 6,4 & None & $N, N, N$ & $-, N,-, N$ & $S, S, S$ \\
\hline Annie, Dau & $\mathrm{F}, 20$ & W, 4 & 2,2 & None & $N, N, N$ & $-, N,-, N$ & S,S,S \\
\hline Hawley, Son & $M, 10$ & $S,-$ & $\because-$ & None & $N, N, N$ & $-, N,-, N$ & $\mathrm{~S}, \mathrm{~S}, \mathrm{~S}$ \\
\hline Winters, Son & $M, 8$ & S,- & $\because-$ & None & $N, N, N$ & $-, N,-, N$ & S,S,S \\
\hline Duke, Son & $M, 6$ & $S,-$ & $\because-$ & None & $N, N, N$ & $-, N,-, N$ & S,S,S \\
\hline ?, Granddau & $F, 6$ & $\mathrm{~S},-$ & $\therefore-$ & None & $N, N, N$ & $-, N,-, N$ & S,S,S \\
\hline Dan, Grandson & $M, 4$ & S,- &,- & None & $N, N, N$ & $-, N,-, N$ & $S, S, S$ \\
\hline Frank & $M, 20$ & $M, 3$ & $\therefore-$ & None & $N, N, Y$ & $-, N,-, N$ & S,S,S \\
\hline Hannah, Wife & $F, 22$ & $M, 3$ & 2,2 & None & $N, N, N$ & $-, \mathrm{N},-, \mathrm{N}$ & S,S,S \\
\hline Dewey, Son & $M, 2$ & $S, 2$ & $\because-$ & None & $N, N, N$ & $-, N,-, N$ & $\mathrm{~S}, \mathrm{~S}, \mathrm{~S}$ \\
\hline Mark, Son & $\mathrm{M}, ?$ & S,- & $\because-$ & None & $N, N, N$ & $-, N,-, N$ & $S, S, S$ \\
\hline Tallion & $F, 30$ & $S,-$ &,-- & None & $N, N, N$ & $-, N,-, N$ & $P, P, P$ \\
\hline Lamopitz, Grandmo & $F, 80$ & $?,-$ & 0,0 & None & $N, N, N$ & $-, N,-, N$ & $S, S, S$ \\
\hline $\begin{array}{l}\text { Grapevine Dock } \\
\text { Gold Mountain }\end{array}$ & $M, 40$ & $w,-$ & $\because-$ & None & $N, N, N$ & $-, N,-, N$ & $S, S, S$ \\
\hline Bill, Son & $M, 20$ & $S_{1}-$ &,-- & Laborer & $N, N, N$ & $-, N,-, N$ & $S, S, S$ \\
\hline
\end{tabular}


Table 4. 1900 Census Data on Native American People in Pahrump Census Precinct (Encompassing All of Southern Nye County) ${ }^{\mathrm{a}}$ (Page 2 of 3)

\begin{tabular}{|c|c|c|c|c|c|c|c|}
\hline Name, Rel. to $\mathrm{HOH}$ & G A & $\begin{array}{l}\text { Mar } \\
\text { CY }\end{array}$ & $\begin{array}{l}\text { Child } \\
\text { D N }\end{array}$ & Occupation & $\begin{array}{l}\text { Language } \\
\text { RWS }\end{array}$ & $\begin{array}{l}\text { Economic } \\
\text { HXAT }\end{array}$ & $\begin{array}{l}\text { Ethnic } \\
\text { E F M }\end{array}$ \\
\hline Gold Mountaln Jack & $M, 55$ & $M, 30$ & $\because$ & None & $N, N, Y$ & $R, N, Y, N$ & $S, S, S$ \\
\hline Susie & $\mathrm{F}, 45$ & $M, 30$ & 4,2 & None & $\mathrm{N}, \mathrm{N}, \mathrm{N}$ & $-, N,-, N$ & S,S,S \\
\hline George, Son & $M, 22$ & $S,-$ & $\because-$ & None & $N, N, Y$ & $-, N,-, N$ & $S, S, S$ \\
\hline Bob, Son & $M, 10$ & $S,-$ & $\because-$ & None & $N, N, Y$ & $-, N,-, N$ & $S, S, S$ \\
\hline Lazy Sam & $M, 45$ & $M, 20$ & $\because$ & None & $N, N, N$ & $-, N,-, N$ & S,S,S \\
\hline Sally, Wife & $F, 35$ & $M, 20$ & 3,1 & None & $\mathrm{N}, \mathrm{N}, \mathrm{Y}$ & $-, N,-, N$ & S,S,S \\
\hline Rosy, Dau & $F, 20$ & $S,-$ &,-- & None & $N, N, Y$ & $-, N,-, N$ & $S, S, S$ \\
\hline Lamopitz, Mother & $F, 60$ & $W, 20$ & 4,3 & None & $\mathrm{N}, \mathrm{N}, \mathrm{N}$ & $-, N,-, N$ & $S, S, S$ \\
\hline Pooya & $M, 25$ & $S,-$ &,-- & None & $N, N, Y$ & $-, N,-, N$ & $S, S, S$ \\
\hline Nettie & $F, 30$ & S,- & $\because-$ & None & $N, N, Y$ & $-, N,-, N$ & $S, S, S$ \\
\hline Dan & $M, 20$ & M, 6 &,-- & None & $N, N, Y$ & $-, N,-, N$ & S,S,S \\
\hline Jane, Wife & $F, 20$ & M, 6 & 3,3 & None & $N, N, Y$ & $-, N,-, N$ & $S, S, S$ \\
\hline John, Son & $M, 16$ & $S,-$ &,-- & None & $N, N, Y$ & $-, N,-, N$ & $S, S, S$ \\
\hline Minnie, Dau & $F, 4$ & $S,-$ &,-- & None & $N, N, N$ & $-, N,-, N$ & S,S,S \\
\hline Lil, Dau & $F, 1$ & S,- &,-- & None & $\mathrm{N}, \mathrm{N}, \mathrm{N}$ & $-, \mathrm{N},-, \mathrm{N}$ & S,S,S \\
\hline Panamint Joe & $M, 35$ & M, 4 & $\therefore-$ & Irrigator & $N, N, Y$ & $R, N,-, N$ & S,S,S \\
\hline Maggie, Wife & $F, 35$ & M, 4 & 0,0 & $\longrightarrow$ & $\mathrm{N}, \mathrm{N}, \mathrm{N}$ & $-, N,-, N$ & S,S,S \\
\hline Tom Utes & $M, 20$ & $M,-$ & $\because-$ & None & $N, N, Y$ & $-, N,-, N$ & S,S,S \\
\hline Rova, Wife & $F, 16$ & $M,-$ & 0,0 & None & $N, N, Y$ & $-, N,-, N$ & S,S,S \\
\hline $\begin{array}{l}\text { Chief Tecopa } \\
\text { Tecopa Charley, }\end{array}$ & $M, 70$ & W,- & $\because-$ & None & $N, N, Y$ & $R, N, Y, N$ & $P, P, P$ \\
\hline $\begin{array}{l}\text { Son } \\
\text { Tecopa Minnie, }\end{array}$ & $M, 23$ & $M, 2$ &,-- & Teamster & $N, N, Y$ & $-, N, Y, N$ & $P, P, P$ \\
\hline Wife & $F, 30$ & $M, 2$ & 0,0 & None & $N, N, Y$ & $-, N, Y, N$ & $P, P, P$ \\
\hline Umbercelt? & $M, 40$ & $M, 11$ &,-- & None & $N, N, Y$ & $-, N, Y, N$ & $P, P, P$ \\
\hline Schusts?, Wife & $F, 38$ & $M, 11$ & 8,6 & None & $\mathrm{N}, \mathrm{N}, \mathrm{N}$ & $-, N, Y, N$ & $P, P, P$ \\
\hline John, Son & $M, 9$ & $S,-$ & $\because-$ & None & $\mathrm{N}, \mathrm{N}, \mathrm{N}$ & $-, N, Y, N$ & $P, P, P$ \\
\hline Phawean (?), Dau & $\mathrm{F}, 7$ & $s,-$ & $\because-$ & None & $\mathrm{N}, \mathrm{N}, \mathrm{N}$ & $-, N, Y, N$ & $P, P, P$ \\
\hline Kanna, Dau & $\mathrm{F}, 5$ & $S,-$ & $\because-$ & None & $\mathrm{N}, \mathrm{N}, \mathrm{N}$ & $-, N, Y, N$ & $P, P, P$ \\
\hline Nancits?, Dau & $\mathrm{F}, 3$ & $s,-$ &,-- & None & $\mathrm{N}, \mathrm{N}, \mathrm{N}$ & $-, N, Y, N$ & $P, P, P$ \\
\hline O.O.S.O., Dau & $\mathrm{F}, ?$ & $S,-$ & $\because,-$ & None & $\mathrm{N}, \mathrm{N}, \mathrm{N}$ & $-, N, Y, N$ & $P, P, P$ \\
\hline Henry & $M, 22$ & M, 5 & $\because,-$ & None & $N, N, Y$ & $-, N, Y, N$ & $P, P, P$ \\
\hline ?, Wife & $F, 18$ & M, 5 & 2,2 & None & $\mathrm{N}, \mathrm{N}, \mathrm{N}$ & $-, N, Y, N$ & $P, P, P$ \\
\hline Golly, Son & M, 4 & $S,-$ &,-- & None & $\mathrm{N}, \mathrm{N}, \mathrm{N}$ & $-, N, Y, N$ & $P, P, P$ \\
\hline Mingham, Dau & $F, 3$ & $S,-$ &,-- & None & $\mathrm{N}, \mathrm{N}, \mathrm{N}$ & $-, N, Y, N$ & $P, P, P$ \\
\hline Jim Oliphant & $M, 48$ & M, 4 &,-- & Irrigator & $N, N, Y$ & $-, N, Y, N$ & $P, P, P$ \\
\hline Rubbin (?), Wife & $F, 45$ & M, 4 & 0,0 & None & $N, N, Y$ & $-, N, Y, N$ & S,S,S \\
\hline
\end{tabular}


Table 4. 1900 Census Data on Native American People in Pahrump Census Precinct (Encompassing All of Southern Nye County) ${ }^{\text {a }}$ (Page 3 of 3 )

Note: The 1900 census of non-Native American people in southern Nye County includes John Howell, his sons Albert and Charles, and his daughter Jennie. The father is identified as white, born in North Carolina. The three children are identified as half-Indian, born in Nevada of a mother (apparently a Native American) whose birthplace is identified as North Carolina.

- Key to columns, from left to right:

- Rel. to $\mathrm{HOH}=$ Relation to head of household. Heads of household are shown in boldface, with all individuals living in the same household indented under the $\mathrm{HOH}$.

- $G=$ Gender $(M=$ male, $F=$ female $)$

- $A=$ Age

- $C=$ Conjugal status $(M=$ married, $S=$ single $)$

- $Y=$ Years married

- $D=$ Number of children, if a mother

- $N=$ Number of surviving children, if a mother

- $R=$ Reads English $(Y=$ yes, $N=$ no)

- $W=$ Writes English $(Y=$ yes, $N=n o)$

- $S=$ Speaks English ( $Y=$ yes, $N=$ no)

- $H=$ Home ( $O=$ owns a home, $R=$ rents a home)

- $X=$ Home is a farm $(Y=$ yes, $N=$ no)

- $A=$ Dwelling of temporary or aboriginal-style construction $(Y=$ yes, $N=n o)$

- $T=$ Pays taxes

- $E=$ Ethnic group affiliation

- $F=$ Father's ethnic group affiliation"

- $M=$ Mother's ethnic group affiliation"

- $P=$ Paiute, $S=$ Shoshone, $D=$ Panamint Shoshone, $W=$ White, $P S=$ Mixed Paiute and Shoshone descent, WP $=$ Mixed White and Paiute descent, and WS = Mixed White and Shoshone descent.

Question marks are used to indicate that handwritten census entries are illegible or uncertain. Dashes are used to indicate the item was left blank on the census form.

Data are from 1900 Census Enumeration for Nevada (microfilm) [Census Office, Department of the Interior, 1901b] 
1902 Shoshones: Oasis Valley: Panamint Range: Native American prospecting: Panamint Joe Stuart - Frank "Shorty" Harris paid Panamint Joe (a Shoshone) fifty dollars to guide him while prospecting in the Panamint Range in the late 1800s. [Weight and Weight, 1953:13]

1902 Oasis Valley: mining camps - There were mining camps all along the Amargosa River, including Beatty, Gold Center (two miles south of Beatty), Springdale, Fluorine, and Pioneer. [Weight and Weight, 1953:17]

1902 Owens Valley: Indian reservations - The first small tract of reservation land was established in 1902. [Liljeblad and Fowler, 1986:430]

1903 Indian Springs: Native American: murder - A 16-year-old half-breed named Cochi murdered a white man while the two were left in charge of a ranch in the owner's absence. [Tonopah Miner, vol. 2, no. 10, August 22, 1903, p. 3, col. 1]

1903 Indian Springs: Native Americans: ranch labor - The Lattimers employed a Native American boy named Coachie. When the Lattimers went to Los Angeles to get treatment for an infection in Mr. Lattimer's hand, they left Coachie in charge of the ranch. Wild Bill, another Indian who did occasional work on the ranch, "was very cruel to this Coachie." Coachie decided to kill him, and did. Coachie served several years in jail, then returned to the ranch "and was accepted as a good and respected Indian." [Boyer, 1967:69-70]

1903 Paiutes: southern Nevada: Indian Springs: relations between Native Americans and Euroamericans - A petition was circulated for presentation to the Board of Pardon "requesting them to commute the sentence of Conchie Seigmiller, the Indian who was sentenced to be hung...for the murder of one William Williams.... It is a common rumor that the Piute Indians in this county understand that Conchie must be punished and they feel that if he gets life imprisonment that he is being punished enough for the murder of such a man as Williams and that they have said, 'Should Conchie be executed they would kill twelve white men.' ["A Good Move," Lincoln County Record, vol. 54, no. 23, November 27, p. 4, col. 2]

1903 Paiutes: southern Nevada: relations between Native Americans and Euroamericans - "T]he people of Southeastern Nevada are very much worked up over the threats of the Piutes to wreck vengeance on the whites of that section should the sentence of death be carried out in the case of Conchie..." ["Bad Feeling Among Indians," Searchlight, vol. 2, no. 23, November 8, 1903, p. 3, col. 6]

1903 Paiutes: Shoshones: Tonopah: Fourth of July: sports - "The Squaw race was won by the Queen of the Shoshones, and Phyllis the Pride of the Piutes, of Hawthorne, got second prize." [Tonopah Miner, vol. 2, no. 4, July 11, 1903, inside p., col. 3]

1903 Native Americans: Pioche: Native American prospecting - "About a week ago an Indian dropped into the Power Plant camp with a piece of ore the size of a man's fist which showed gold quite freely...It caused quite an excitement, and all attempts to get any information from the Indian about whence it come or where he found it has been fruitless. All he would say, "Me find him mountain." [local news page, Pioche Weekly Record, vol. 54, no. 6, July 31, 1903, p. 4, col. 4]

1903 Searchlight: Needles: Native Americans: employment - An advertisement in the Searchlight for railroad construction laborers included the following: "white laborers, $\$ 2.00$ per day, of ten hours; Mexicans and Indians, $\$ 1.75$ per day of ten hours."

[Searchlight, vol. 2, no. 4, July 3, 1903, p. 6, col. 2] 
1903 Native American: Reno: funeral - The corpse of Johnson Sides, "a good Indian," was returned from California and "buried like a white" in Hillside cemetery. The pallbearers and chief moumers were Native Americans. Two clergymen gave eulogies at the service in the park across from the courthouse. [Tonopah Miner, vol. 2, no. 18 , October 17,1903 , p. 2, col. 2]

1904 Shoshones: Beatty area: Native American prospecting: Shoshone Johnny: Indian Johnny - Shoshone Johnny, originally from the Panamint area, "showed Bob Montgomery the richest gold mine in all the Death Valley country - the Montgomery Shoshone, the mine that made the Bullfrog boom." [Lingenfelter, 1986:20]

1904 Paiutes: Caliente: hostilities between Native Americans and Euroamericans "Two prospectors... are reported to have been killed by Piute Indians near Caliente... in Arrow Canyon range....The murder is laid to the Piute Indians from the Moapa reservation, who have been ugly of late. Many small parties have left the reservation and are now roving about, committing depredations on ranches and camps of the surveyors or prospectors. A general uprising is feared...The above press dispatch lacks confirmation and is probably a gross exaggeration...." ["Two Prospectors Murdered," Searchlight, vol. 2, no. 31, January 8, 1904, p. 1, col. 4]

1904 Native Americans: Pahrump: Chief Tecopa - Tecopa was "Paiute chieftain of all the Indians in the southern part of Nevada and part of California....[and] was a very old man at the time of his death... He'd hung on tenaciously to life because his son, who would have succeeded him as chieftain, was just plain no good. He kept hoping that the son would either die or reform, because he hated to leave his people at the mercies of this no-account person." [Boyer, 1967:76-77]

1904 Native Americans: Goldfield: Fourth of July: sports - The program of events for the Fourth of July included a "Squaw race, 100 yards, prize, \$5." ["The Fourth at Goldfield," Tonopah Miner, vol. 3, no. 3, July 2, 1904, inside p., col. 2]

1904 Bulfrog district: mining activities - Gold was first discovered in the Bullfrog district in summer 1904. [Greene, vol. 2, 1981:1]

1904 Shoshones: Tonopah: woodcutter - Shoshone Charley was hired to chop firewood. He shared the work with "about ten of his younger tribesmen." Later he was paid with a check, the first he had ever received. [Tonopah Miner, vol. II, no. 32, January 30, 1904, p. 6, col. 2]

1904 Tonopah: railroad - The railroad line connecting Tonopah to the Southern Pacific was completed in 1904. [Greene, vol. 2, 1981:168]

1904 Kawich Range: mining activities - A very active prospecting waterway was in the Kawich district, five and a half miles east of Goldfield. [Tonopah Miner, vol. 3, no. 29, December 31, 1904, p. 1, col. 1]

1904 Johnnie district: mining activities - There was a revival of mining in the Johnnie district, involving a small camp of about 100 prospectors. [Lingenfelter, 1986:352]

1904 Carrara area: mining activities - The Carrara Marble Company, located ten miles southeast of Beatty, was established in 1904. Its works were dismantled in 1936. [Kral, 1951:63] 
1904 Gold Crater district: mining activities - Discoveries were made in 1904, followed by limited production in the Gold Crater district, 27 miles southeast of Goldfield. [Kral, 1951:69]

1904 Kawich district: mining activities - The area was named for Chief Kawich who lived in the vicinity. The first locations were made in 1904. In 1905, several hundred men rushed to the camps, Gold Reed Camp and Queen City Camp. [Kral, 1951:90-92]

1905

1905 Shoshones: Oasis Valley: settlement: Panamint Joe Stuart - "At Panamint Joe's place, ten miles north of Beatty on the west side of the river, are springs flowing about fifteen inches." ["Water Sources," Beatty Bullfrog Miner, vol. 1, no. 29, October 7, 1905, p. 2, col. 2]

1905 Shoshones: Beatty: ranch: Panamint Joe Stuart - Panamint Joe Stuart owned a ranch north of Beatty. [Bulfrog Miner, vol. 3, no. 1, March 30, 1905, inside p., col. 3]

1905 Native Americans: Beatty: Fourth of July: sports - A listing of Fourth of July contests and prizes included: "Indian Saddle pony race, 1 st prize $\$ 25$, 2nd prize $\$ 10$. Squaw race on horses, $\$ 25$ prize." ["Fourth at Beatty," Beatty Bullfrog Miner, vol. 1, no. 13, June 17, 1905, p. 6, col. 3; "4th at Beatty," Beatty Bullfrog Miner, vol. 1, no. 15 , July 1,1905 , entire p.]

1905 Native Americans: Beatty: Fourth of July - Native American 'braves' and 'squaws' were reported as attending the Fourth of July barbecue. [Beatty Bullfrog Miner, vol. 1, no. 17, July 15, 1905, p. 3, col. 1]

1905 Native Americans: Ash Meadows: Black family: murder - "Dave Black, the Indian who some months ago killed three or four men of his own race near the Ash Meadows road, and who is supposed to have killed several white prospectors that were found murdered in that section, has been located in hiding. Several Indians came in a few days ago advising the authorities of Black's hiding place. The man has not yet been taken into custody, but undoubtedly will be very soon." [Goldfield Review, vol. 1, no. 38, July 13, 1905, p. 6, col. 2]

1905 Paiutes: Pahrump: funeral ceremonies: Chief Tecopa - About 100 Paiutes met at Pahrump for feasting and dancing, then offered sacrifices at the grave of Chief Tecopa. Several ponies were killed and clothing was bumed to honor the Chief, who died about a year earlier and was buried in a suit that was a gift from George Montgomery. The pow-wow participants recounted "the glorious days when Piutes put the Shoshones to flight...not long ago the Piutes and Shoshones met at Reno and buried the war hatchet...In his last years Chief Tecopa worried about his successor. Tecopa means wildcat, and his son John had some traits of that animal, which made the good father doubtful about allowing John to wear his shoes." ["Indian Powwow," Beatty Bulffrog Miner, vol. 1, no. 27, September 23, 1905, p. 1, col. 1]

1905 Paiutes: southern Nevada: population - "Mr. Harsha White, who took the census, says the Piute population has decreased 60 per cent since 1890. The white man's whiskey and biscuits and love have wrought their undoing....Not more than one 
hundred bucks, squaws and children gathered to dance, feast, and give sacrifice to appease the wrath of the Great Spirit that is calling them to the hunting ground rapidly." [Beatty Bullfrog Miner, vol. 1, no. 27, September 23, 1905, p. 1, col. 1]

1905 Shoshones: Beatty: Native American prospecting - A Native American man hired to do prospecting by E.A. (Bob) Montgomery reportedly made the first locations of ore on Montgomery Mountain. [Beatty Bullfrog Miner, vol. 1, no. 33, November 4, 1905, p. 1, col. 4]

1905 Paiutes: Pahrump: Chief Tecopa's funeral - Tecopa, pakwinavi of Pahrump, died. His mourning ceremony drew Paiutes from as far as the Colorado River and across Death Valley. [Lingenfelter, 1986:22]

1905 Native Americans: Oasis Valley: intermarriage of Native Americans and Euroamericans - M.M. Beatty came to the area in 1894 and bought a ranch from W.W. Stockton, who had settled there in 1877. Stockton was identified as a "squaw man" since he had a Native American wife (then deceased). (Beatty himself married a Shoshone woman.) In 1905, M.M. Beatty became postmaster. Beatty was described as "very popular with whites and reds alike." [Tonopah Miner, vol. 4, no. 5, July 15, 1905, p. 6, col. 4]

1905 Paiutes: Nevada: employment - Native American families from whom pupils of Walker Piver School were drawn "live in scattering settlements, few in a place..." They were self-supporting, living by their labor on the ranches and in the families of white people, where they were in great demand. [CIA, 1905:242]

1905 Paiutes: Ash Meadows area: Black family: murders: relations between Native Americans and Euroamericans - Many deaths in Ash Meadows and the surrounding region were attributed to a member of the Black family of Ash Meadows. "Dave Black, the Indian who some months ago killed three or four men of his own race near the Ash Meadow road, and who is supposed to have killed several white prospectors in that section, has been located in hiding. Several Indians came in a few days ago advising the authorities of Black's hiding place. The man has not yet been taken into custody..." ["A Tough Indian," Goldfield Review, vol. 1, no. 38, July 13,1905 , p. 6, col. 2]

1905 Native Americans: Ash Meadows area: Black family: murders: relations between Native Americans and Euroamericans - In January 1905, Bob Black went on a "murderous binge in which he killed at least four people, including his squaw, his brother, and two other men" and then went into hiding. In June, the partially buried bodies of three more murdered prospectors were discovered on the north side of the Funeral Range. Soon after, Native American people learned where Bob Black was hiding. "Although they usually preferred to deal with Indian criminals according to tribal custom without interference from white legal authorities, Indian representatives arrived in Goldfield in the summer of 1905 begging lawmen to come after Bob Black so that he could kill no more. But no arrest was made. Fannie Longstreet, Bob Black's sister, asked Longstreet to give sanctuary to her brother at his ranch in the Monitor Range. Black worked on Longstreet's ranch, and the two went prospecting together. Black found ore at Longstreet Canyon." In 1910, Longstreet killed Black after Black threatened to kill him. [Zanjani, 1988:113-119] 
1905 Shoshone: Beatty: guide - Mr. Weller, father of a young prospector who died in the desert, employed a Shoshone as a guide in searching for his lost son. [Tonopah Miner, vol. 4, no. 13, September 9, 1905, p. 7, col. 2]

1905 Paiutes: southern Nevada: population - "Mr. Harsha White, who took the census, says the Piute Indian population has decreased 60 per cent since 1890. The white man's whiskey and biscuits and love have wrought their undoing." ["Piutes Hold Carnival at Grave of Chief Tecopa," Goldfield Review, vol. 1, no. 49, September 28, 1905, p. 2, col. 6]

1905 Native Americans: Lida: settlement: murder - A man was killed in a "squaw camp about a quarter of a mile away" from Lida. "George A. Logan is believed to have been the slayer. The two men went out from Lida to a squaw camp about a quarter of a mile away....A party of men went out to the camp and found the unknown man lying dead in the center of a circle of squaws who were lamenting after the weird manner of their race.... One of the squaws ceased her death chant and pointed her finger at Logan, exclaiming: 'You killed him. You shot him in the back.' Other squaws made the same accusation." ["Unknown Man Killed in Squaw Camp Near Lida," Tonopah Daily Sun, March 21, 1905, p. 1, col. 3]

1905 Oasis Valley area: water resources - At Goss Springs the flow from two springs totaled 18 cubic feet/minute $(425,000$ gallons a day). [Tonopah Miner, vol. 4 , no. 1 , June 17, 1905, p. 6, col. 1]

1905 Oasis Valley/Beatty: water resources - For 12 miles along the Amargosa, there were ranches and homes. [Rhyolite Herald, vol. 1, no. 19, September 8, 1905, p. 1, col. 1]

1905 Oasis Valley: water resources - Bullirog Water, Power and Light Company bought Beatty's ranch and water rights. [Rhyolite Herald, vol. 1, no. 19, September 8, 1905]

1905 Oasis Valley: water resources - A newspaper lists the springs supplying camps in the Bullfrog area. Most are north and east, in or adjacent to the Amargosa river bed (including Panamint Joe's ranch, ten miles north of Beatty). [Beatty Bullfrog Miner, vol. 1, no. 29, October 7, 1905, p. 2, col. 2]

1905 Amargosa Canyon: railroad construction - By fall 1905, up to 900 men were working along an 11-mile stretch of the Amargosa, building the Tonopah and Tidewater Railroad. [Lingenfelter, 1986:386]

1905 Fortymile Canyon: mining activities - "Recent reports of strikes east of Beatty as far as Forty Mile Canyon, 50 miles from here, have started a rush of prospectors in that direction. H.F. Porch, L.V. Lonsway, Percy McCabe and Jack Gosworthy own several claims in Forty Mile Canyon. Col. Ed. F. Brown has a party in there under the charge of Hugh Willis. G.A. Sexton has gone out in his own interests....Messrs. Blumlein...and Oscar Jamieson went out two weeks ago. C.L. Engle and $W$. Beck left Beatty on a prospecting trip in the same country last week. Water is hauled 15 miles from Cane Springs on the Las Vegas Toll road." ["40 Mile Canyon," Beatty Bullfrog Miner, vol. 1, no. 21, August 12, 1905, p. 5, col. 2]

1905 Transvaal district: mining activities - After a new gold strike, 18 to 20 rigs went out "with prospectors and locators on Tuesday. All day Wednesday teams, saddlehorses, burro outfits and men afoot streamed out to the strike." [Bullfrog Miner, vol. 2, no. 2, March 30, 1905, inside p., col. 3] 
1905 Bare Mountain: mining activities - Marble beds were discovered on Bare Mountain. [Lingenfelter, 1986:404]

1905 Fluorine district: mining activities - Gold was discovered on the east side of Bare Mountain. [Kral, 1957:60]

1905 Bare Mountain/Fluorine: mining activities - Gold was discovered. [Cornwall, 1972:35]

1905 Oak Spring area: mining activities - Development work was underway on gold prospects at the north end of Yucca Flat. [Cornwall, 1972:38]

1905 Oak Spring area: mining activities - "Jack Burgess, Jack Miles, and Messrs Marty and Spears own claims at Oak Springs...They get values as high as $\$ 100$ and have a shaft down $\mathbf{4 0}$ feet. Lawrence and partner are also doing a great deal of work at Oak Springs and obtain values of $\$ 150$. Burgess and Miles also have good copper properties there. Outfitting for the Springs is done at Beatty, and they drive from here in a wagon all the way." ["Oak Springs," Beatty Bullfrog Miner, vol. 1, no. 20, August 5, 1905, p. 6, col. 1]

1905 Johnnie: town - The town of Johnnie was laid out in 1905, just northwest of the Pahrump Valley. "By 1907, the town had several saloons, stores, restaurants, and hotels." [Kensler, nd:II-237]

1905 Wahmonie district: mining activities - The Hornsilver mine was operating in the vicinity of Skull Mountain. [Cornwall, 1972:41]

1905 Kawich district: mining activities - Considerable prospecting and development work were underway, and there were several camps. The Goldreed or Kawich Silver Bow Camp had about 300 residents. [Tonopah Miner, vol. 4, no. 22, November 11, 1905, p. 1, col. 1]

1905 Ballarat area: mining activities - There was a mining boom around Ballarat. [Tonopah Miner, vol. 4, no. 21, November 4, 1905, p. 2, col. 1]

1905 Lida area: mining activities - A new prospecting rush began in 1904. By 1905 , there was a population of about 600 at Lida. [Lingenfelter, 1986:340]

1905 Owens Valley: water resources - The city of Los Angeles began to acquire water rights and irrigated land in southern Owens Valley. [Liljeblad and Fowler, 1986:430)

\section{6}

1906 Shoshones: Rhyolite: commercial activities - "Thhe increasing importance of the white man's economy...drew Indian people into new activities and into regions outside their native districts....during the Rhyolite mining boom in 1906 they left their farms to haul wood for the mines." [Steward, 1938:89]

1906 Shoshones: Bullfrog: camp - A photograph showing a group of Native Americans around a cooking fire in a brush windbreak is inscribed on the back with "our neighbors at Bullfrog Nevada, 1906." [Ethnic File, Photo Collection, Nevada Historical Society, reprinted in Thomas et al., 1986:274, where it is identified as a Shoshone camp] 
1906 Shoshones: Oasis Valley area: Native American prospecting: Indian Johnny - In a court case involving conflicting claims to the Montgomery Shoshone mine, the defendants testified that Bob Montgomery hired Indian Johnny to prospect with him and that the two located two claims, with Montgomery later locating another nearby claim on which the Montgomery Shoshone mine was later developed. [Rhyolite Herald, vol. 1, no. 36, January 5, 1906, p. 1]

1906 Shoshones: Bullfrog: court hearing: Indian Johnny - Indian Johnny told the court he must have an interpreter, then disappeared, afraid that his inability to recall exact dates would land him in jail. [Rhyolite Herald, vol. 1 , no. 36 , January 5 , 1906, p. 1]

1906 Native Americans: Oasis Valley: prospecting: settlement: Indian Johnny - Indian Johnny's affidavit of July 2, 1905, reads: "I remember the time last fall when Bob Montgomery and Pat O'Brien left Howell's ranch for Goldfield, the day before we cut watermelons at Howell's ranch, and the day they left for Goldfield Bob and Pat bought some watermelons at Indian ranch.... It was about ten days before that day that Bob went to Goldfield, and Bob asked me to go prospecting. About a week before they went to Goldfield I located two claims. I built monuments and put the papers in the monuments: the papers Bob told me were notices. Bob wrote them out over at my house at Indian ranch. When Bob came over with me to see them he said there was no gold in the rock. He took some rock from the claims to have it assayed....These two claims were Shoshone and Indian Johnnie. When Bob came to see the claim before he went to Goldfield I saw him put up another notice and monument. I helped him put up the monument...I put up two monuments myself and I helped Bob put up the monument near where the tunnel now is.... On the day that Bob and Pat went to Goldfield, Bob told me to go prospecting again. I prospected after he left, but did not find anything good....The claim located by Bob and I, where the Montgomery mine now is, was named Shoshone No. 2, but I do not know whether it had any more names or not. It was the same ground where the big Montgomery mine now is, called the Shoshone No. 2..."

Bob Montgomery testified "that he first became acquainted with the Indian at Howells ranch....Learning Johnnie had some knowledge of rock, Montgomery employed him, purchased supplies from Howell for him, and next day at Indian ranch directed him to prospect to the westward of where the parties then were; gave the Indian some location notices and an order on one Chiatovich for more 'grub' and dating the location notices ahead to suit Johnnie's convenience, departed with O'Brien for Goldfield. That on Montgomery's return to Bull Frog district on the 23rd of September he met the Indian prospector at Beatty, and was taken by him to the Shoshone and Indian Johnnie locations on the 24th of September."

"As to the employment of the Indian by the defendant, Montgomery, he is corroborated by O'Brien in all details, save as to the date...." ["Full Text of Judge Breen's Decision," Beatty Bullfrog Miner, vol. 1, no. 42, January 6, 1906, pp. 3-4]

1906 Paiutes: Oasis Valley - Oasis Valley is identified as a traditional Paiute area, a "memorable haunt of the Piutes." [Rhyolite Herald, vol. 2, no. 8, June 22, 1906, inside p., col. 3] 
1906 Native Americans: Oasis Valley: settlement: Panamint Joe Stuart: Lulu Jackrabbit - "Lulu Jackrabbit, an Indian woman, the wife of George Jackrabbit, was struck by lightning Tuesday near Panamint Joe Stuart's ranch, about 12 miles north of Rhyolite, and instantly killed....She was buried Wednesday according to the native rites and ceremonies. Panamint Joe officiated and delivered the funeral sermon. Only two white men were present...." ["Killed by Lightning," Bullfrog Miner, vol. 2, no. 18 , July 27,1906 , inside p., col. 1]

1906 Shoshones: Rhyolite and Bullfrog: commerce: Panamint Joe Stuart - Panamint Joe Stuart and his people moved to the Grapevine Mountains and began supplying firewood to Rhyolite and Bullfrog. [Lingenfelter, 1986:21]

1906 Shoshones: Beatty: ranch: Panamint Joe Stuart - Panamint Joe Stuart reportedly was in the process of selling his ranch north of Beatty and of moving his band to Inyo. The move was apparently in response to the death of Mrs. Lulu Jackrabbit, who was struck by lightning at the ranch. ["Panamint Joe Gets Message From Clouds," Bullfrog Miner, vol. 2, no. 26, August 31, 1906, p. 1, col. 2]

1906 Shoshones: Oasis Valley: settlement: commerce: Panamint Joe Stuart - "Panamint Joe sold his ranch to A.L. Lidwell and will move his people to a wood camp, about 30 miles west. His camp numbers about 25 people. He was born at the Beatty ranch and has always lived in that vicinity. He says he will engage in hauling wood to Rhyolite." ["Superstition of Panamint Joe," Bullfrog Miner, vol. 2, no. 24, September 7, 1906, p. 3, col. 6]

1906 Shoshones: Oasis Valley: village: Panamint Joe Stuart - "Springdale is situated...about ten miles north of Rhyolite as the crow flies. Previous to the coming of the white man, this spot was inhabited by the Indians, Panamint Joe having fenced in some ground around the springs and built himself a typical Indian camp. About three years ago, A.L. Lidwell secured the ranch from Panamint Joe, and established a townsite, which, after a few months, gained the advantage of a railroad....the old Indian ranch grew into quite an important trading point." ["Springdale, Gateway from the North," Rhyolite Herald Pictorial Edition, Midwinter Supplement, March 1909]

1906 Shoshones: Rhyolite: commerce: Panamint Joe Stuart - Panamint Joe Stuart was in Rhyolite selling pine nuts. [Bullfrog Miner, vol. 2, no. 24, September 7, 1906, inside p.]

1906 Shoshones: Oasis Valley: ranch - There was prospecting activity in Oasis Valley, eight miles north of Rhyolite. A new strike was made on what is referred to as 'the old Indian Joe ranch.' [Bullfrog Miner, vol. 2, no. 34, November 16, 1906, inside p., col. 3]

1906 Native Americans: Ash Meadows: ranching: farming: Ash Meadows Charley: Mary Scott - "Ash Meadows Charley, an Indian, has a 200 acre ranch. Mary Scott, an Indian, grows vegetables, hay, and stock on 160 acres." [Beatty Bullfrog Miner, vol. 1, no. 44, February 3, 1906, p. 3, col. 4]

1906 Native American: Nye County: Native American prospecting: Native American mining claims - Johnnie Peavine, a Native American, claimed in a court hearing that he and his Native American wife found rich ore at Clifford "to which they directed the Clifford party upon condition that they were to receive an equal share in the property which was to be located and developed for patent by the Cliffords. The 
latter, it is claimed, after locating many valuable claims and townsite, turned the Indians adrift with no other recompense than a promise to pay, with a face value of about $\$ 6,000$. This note has never been paid and the Indian says he was under the impression that it was his deed to a full interest in the property." Judge Breen held "that an Indian can own and hold real estate in the form of mining claims, sue and be sued the same as other citizens of this country. This opinion was delivered in one of the most important grubstake cases pending in the local court and clears the way for a trial of the case which involves property which was recently sold for about \$250,000." ["Indian Rights," Beatty Bulffrog Miner, vol. 2, no. 7, May 5, 1906, p. 2, col. 2]

1906 Native American: Beatty: death by pneumonia: Captain Jack - "Captain Jack's wife, an old Indian woman about 80 years old, died Friday of pneumonia. She was born in Oasis Valley and spent most of her life in this immediate vicinity." [Beatty Bullfrog Miner, vol. 2, no. 37, December 1, 1906, p. 12, col. 2]

1906 Native Americans: Searchlight: Native American mining claims: murder - "Jim Monaghan, a full-blooded Piute Indian, fatally wounded Captain Mullen and shot a hand off Joe Babbon, also Indians, in a drunken row over a squaw. The three own valuable mining property in the mountains and had brought in the month's ore output. After celebrating with a gallon of whiskey Babbon and Mullen went to Monaghan's tent to get the latter's squaw. All were armed with Winchester rifles....Mary Shixee, Monaghan's squaw seized Monaghan's other gun when the officers entered the ten, but was overpowered atter a terrific struggle." ["Squaw Causes Gun Fight Between Indians," Tonopah Daily Sun, March 29, 1906, inside p., col. 1]

1906 Paiutes: Shoshones: Tonopah: Fourth of July - An article includes as number 16 in a list of 23 parade participants "100 Piute and Shoshone Indians." ["Order of the Grand Parade," Tonopah Daily Sun, July 3, 1906, inside p., col. 3]

1906 Native Americans: Tonopah: Fourth of July - "One of the striking features of the Fourth of July celebration in Tonopah will be the participation of the Indians of this section under the leadership of Captain Johnnie Kay, the headman of the Indians in Nevada. At the time of the oratorical portion of the celebration Captain Kay will tell of the great gold region of southwestem Nevada as it was in the old days before the white men came. Captain Johnnie Kay is quite a character. About two years ago Chief Johnson Sikes, the aged head of the red men of the Nevada desert, died in Preston, California. The old chief had been a father to his people for many years and had led them down into the hopfields of California each summer that they might make a little money....Captain Johnnie Kay was one of Chief Johnson's men and when the leader lay on his death bed, he called Kay to him and charged him with the care of his people....Following the orders of his leader, Kay has each year gathered the desert people together in the late summer and taken them to California for a two months' trip to the hopfields. It is the chief who arranges with the railroad for cars to carry the redmen over the hills, and who must know the whereabouts and occupation of all the scattered bands. To do this it is necessary that he should travel from one end of the state to the other and the railroads take him to any part of the line without charge. Captain Kay is a familiar sight wherever the Indians gather in the state..." ["Indians Will Join in Celebration," Tonopah Daily Sun, July 3, 1906, inside p., col. 4] 
1906 Native Americans: Walker River reservation: Native American mining claims "Several hundred Indians, led by Chief Johnnie Kay, are seeking to secure mineral claims in the Walker River reservation under the decision of Judge Peter Breen of Tonopah that an Indian can take up and hold a mining claim. They threaten to lead the rush to locate in the reservation." ["Indians Will Locate Claims," Tonopah Daily Sun, October 20, 1906, p. 1, col. 5]

1906 Native American: Tonopah: dance - "Last night marked the close of a ten days and nights' Indian dance, held near here....It proved a great attraction for prospectors and townsite people coming here for supplies...The dancers formed one large ring or circle and were, doubtless, grunting the same guttural, monotonous airs as those emitted by their remote ancestors... On the side of the grounds an inner tent had been transformed into an improvised grocery store and butcher shop by one of the bucks who was using to advantage his elementary knowledge of civilization and was gathering unto himself that most potent factor - money - while a younger buck was successfully manipulating a modem graphaphone (sic) or talking machine supplied with the latest records." ["Piute Indians Give a Big Dance. Indians at Schurz Perform for Spectators. White Men Get Permission to Join in and Wild Time Follows Acceptance," Tonopah Daily Sun, November 26, 1906, inside p., col. 1]

1906 Native Americans: Walker Lake: Native American prospecting - "Bertha Williams and Lee Foster, two well-known Indians, came in this week from some point in the Walker Lake reservation with a pack-horse laden with rich samples of gold ore, gathered by them in the reservation, says the Aurora Borealis.... The samples go to show what we have heretofore asserted, that the reservation is rich in the precious metals and should be thrown open to prospectors at an early date." ["Rich Ore from Indian Reservation," Tonopah Daily News, February 2, 1906, inside p., col. 2]

1906 Disease: Tonopah: Goldfield - "Numerous deaths are reported in Tonopah and Goldfield from cold, exposure, and pneumonia." [Beatty Bullfrog Miner, vol. 2, no. 38, December 8, 1906, p. 12, col. 2]

1906 Gold Center: town - The town of Gold Center was platted in 1904. In 1906, it became the terminus of the Las Vegas and Tonopah Railroad and briefly served as a railhead for Rhyolite. The peak year of Gold Center was 1907. It had a post office, bank and trust company, newspaper (Gold Center News), hotel, several saloons and stcres, and a brewery. [Paher, 1970:321]

1906 Paiutes: Nevada: employment - The Indian Agent reported that Paiutes from the Walker River reservation were "in constant demand all over Western Nevada as ranch hands for the white land owner;" were excellent cattle hands; and received the same wages as their fellow workers among the whites. [CIA, 1906:257]

1906 Paiutes: Nevada: employment - The Indian Agent reported that the population of Walker River reservation and Wadsworth varied "continually on account of their nomadic propensities.... In the spring and summer they....wander away, the men to work in the fields and on the cattle ranges, the women to find work near where the men are occupied....Paiute women's work as housemaids and in the laundry is in great demand." [CIA, 1906:258] 
1906 Paiutes: Nevada: railroad labor - The Indian Agent reported that "[t]he superintendent of the Nevada Railroad Company employed all [the Paiutes] he could hire as graders, and informs me that Indian labor is much more satisfactory than whites in the same capacity." [CIA, 1907:271]

1906 Paiutes: Nevada: residence in towns - The reservation field matron at Walker River contrasted the condition and habits of supervised reservation Indians with those who were "living unrestrained lives on the outskirts of the railroad towns or mining camps." [CIA, 1907:273]

1906 Nevada Indians: ranch labor - The Indian Agent reported that "Dr. W.H. Patterson, of Reno...a ranch owner, authorized me to employ 20 Indians at $\$ 2.50$ per day to work on his ranch." The Gerlock Cattle Company at Granite Creek employed Native Americans at the same rate of pay. [CIA, 1907:271]

1906 Oasis Valley: water resources - There was enough water "for a stamp mill on every hillside" and for irrigation. [Rhyolite Herald, vol. 2, no. 8, June 22, 1906, inside p., col. 3]

1906 Oasis Valley: agriculture - A newspaper reported that most of the ranches in the Oasis Valley had been purchased by "capitalists." The Beatty Company owned four ranches: White ranch, Davis ranch, and two of the Howell ranches. [Rhyolite Herald, vol. 2, no. 8, June 22, 1906, inside p., col. 3]

1906 Johnnie: railroad construction - A railroad station opened at Johnnie, 43 miles from Rhyolite (75 miles from Las Vegas). Work was being held back by scarcity of labor for the road crews. [Bulffrog Miner, vol. 2, no. 9, May 25, 1906, p. 1, col. 3]

1906 Amargosa: railroad construction - A Mexican man working on the steelgang of the Las Vegas and Tonopah Railroad was murdered near Rosewell. [Bullfrog Miner, vol. 2, no. 18, July 27, 1906, p. 2, col. 5]

1906 Amargosa Valley: railroad construction - The construction force working on the Tonopah and Tidewater Railroad was increased to 1,000 men and 900 teams. "The grading camps have stretched out for fully 15 miles north of Amargosa Canyon....Within the canyon men are working like swarms of bees." The work there would require 60 days or more. [Rhyolite Herald, vol. 2, no. 34, December 21, 1906, p. 1, col. 5]

1906 Beatty: Rhyolite: Gold Center - Railroad service to Gold Center and Beatty began in October 1906. Service to Rhyolite began in December 1906. [Greene, 1981:173]

1906 Rhyolite: railroad - The Rhyolite freight yards were reportedly overflowing. "[E]very available team is employed in hauling freight." [Rhyolite Herald, vol. 2, no. 35, December 28, 1906, inside p., col. 5]

1906 Oasis Valley: agriculture - Indian Creek ranch was leased to the "Kimball boys," sons of L.P. Kimball of Kimball Brothers. Beatty's ranch produced melons and beets. W.H. Eddy of the Patrick water system managed the Beatty ranch. [Bullfrog Miner, vol. 2, no. 26, September 21, 1906, p. 5, col. 5]

1906 Fortymile Canyon: mining activities - "J.D. Donahoe returned from a two weeks prospecting trip in the Forty Mile canon country.... He states that he and a companion located six claims...and...says there are a number of fine prospect[s] already located in various sections of the country." ["Forty Mile Canon," Beatty Bulffrog Miner, vol. 2, no. 26, September 15, 1906, p. 9, col. 1] 
1906 Fortymile Canyon: mining activities - "Many prospectors inform us that 25 or 30 miles east of Beatty is a good country, rich in minerals...Some copper claims have been staked in Forty Mile Canyon, and gold has been found near Oak Springs....A road leads east from Beatty to Forty Mile Canyon, and thence northeast to the Groom district. All this territory is practically unexplored and offers a good field for prospectors." ["Forty Mile," Beatty Bullfrog Miner, vol. 2, no. 40, December 22, 1906, p. 4, col. 2]

1906 Fortymile Canyon: mining activities - In 1907, an old lead-silver mine was discovered in Fortymile Canyon. "A few miles away is a great lake bed, full of water at this season. One ex-Beatty resident recalls that an outfit of Mexicans mined in the area over 20 years before." [Beatty Bullfrog Miner, vol. 2, no. 46, February 23, 1907, p. 2, col. 2]

1906 Bare Mountain: mining activities - Several companies were engaged in development work for gold, silver, copper, and lead mines. [Rhyolite Herald, vol. 2, no. 15, August 10, 1906, p. 1, col. 5]

1906 Pocopah district: mining activities - A newspaper reported prospecting and development activities around Pocopah, 35-40 miles east of Rhyolite, 28 miles north of Ash Meadows, and 8 miles from Fortymile Canyon. ["Pocopah the Latest: Ideal Mining Section North of Ash Meadows Attracts Attention," Rhyolite Herald, vol. 2, no. 16, August 17, 1906, p. 1, col. 5]

1906 Pocopah: mining activities - "A new gold-copper district is being opened up about 35 miles east of Rhyolite. It has been named the Pocopah district, which is a Piute word meaning hidden water. H.H. Dickson, who has been out for Judge Ray and C.S. McLaren returned from the new camp this week and he brings a good report Deal Brothers \& Mendenhall and Fairbanks \& Hovey have extensive holdings in the new territory." ["Pocopah - New Camp," Bulffrog Miner, vol. 2, no. 21, August 17, 1906, p. 6, col. 3]

1906 Pocopah: mining activities - The Pocopah Copper Company owned ten claims in the Pocopah copper district. ["Pocopah," Bulltrog Miner, vol. 2, no. 40, December 28,1906, p. 10, col. 6]

1906 Transvaal: mining activities - After gold discoveries in 1906, a short-lived tent city grew at Transvaal, just north of Yucca Mountain and southwest of Timber Mountain. [Kensler, nd: 2-215]

1906 Transvaal: mining activities - The Transvaal district was organized (bounded north by Indian ranch, south by Amargosa Wash, west by the Amargosa river). The area measured about 9 miles by 15 miles. [Bullfrog Miner, vol. 2, no. 2, April 6, 1906, p. 1, col. 1]

1906 Transvaal: mining activities - The new camp of Transvaal had a population of 700-900. It was five miles from Beatty by stage. [Rhyolite Herald, vol. 2, no. 1, May 4, 1906]

1906 Transvaal: mining activities - Fifteen miles northeast of Beatty, the new camp had 50 tents and buildings and "dozens of teams and outfits" arriving daily. [Beatty Bullfrog Miner, vol. 2, no. 3, April 7, 1906, p. 1, col. 1] 
1906 Transvaal: mining camp - The population of Transvaal reached as high as 800 , but the boom was short-lived. [Paher, 1970:326]

1906 Tecopa: mining activities - Mining was revived at Tecopa. By 1907, there was a camp of nearly 100 men. [Lingenfelter, 1986:357]

1906 Ubehebe Range: mining activities - A "lost Spanish mine" was discovered by A.D. Whittier, ten miles southwest of Rhyolite. An old Mexican said that, according to tradition, it was worked by Indians before the Spaniards took possession. [Bullfrog Miner, vol. 2, no. 28, October 5, 1906, p. 1, col. 1]

1907

1907 Native Americans: Rhyolite - A photograph shows nine Native Americans seated in front of a building and is inscribed "Some of Rhyolite's First Inhabitants, April 1907." [A.E. Holt album, Photo Collection, Nevada Historical Society]

1907 Native Americans: Beatty: Fourth of July: sports - George Birt's horse won a race. The rider was "an Indian girl." [Beatty Bullfrog Miner, vol. 3, no. 15, July 6, 1907, p. 1, col. 2]

1907 Native Americans: Beatty - "An animal spirited encounter on the street Christmas day between two native daughters furnished amusement for the entire male population of Beatty. The 'other Indians' early became disgusted with the sight and slunk off, leaving the whole of the fun to their white brethren." [local news column, Beatty Bullfrog Miner, vol. 3, no. 40, December 28, 1907, p. 1, col. 2]

1907 Paiutes: Pahrump: camp: murder: Indian Charley - "It seems that Chas. Clay.....went to a tent occupied by an Indian called Little Charley, only a short distance from the ranch house, and demanded that the latter get him [Clay] a squaw. Indian Charley, with several other Indians there, tried to persuade the intoxicated man to go back to the ranch house and go to bed, but this he refused to do. Upon the refusal of the Indians to produce a squaw, Clay pulled his six shooter. At this an Indian named Weeds grabbed Clay from behind and attempted to take the gun away from him but was not successful. Clay then fired one shot at the Indians which missed, but the second one struck Indian Charley....Deputy Sheriff Casey remained at the scene of the killing and with a posse of Indians will try and apprehend Clay....The Indians belong to the Peyote tribe." ["Indian Was Murdered:

Redskin Killed at Pahrump Ranch Monday," Rhyolite Daily Bulletin, vol. 1, no. 4, September 26, 1907, p. 1, col. 2]

1907 Native Americans: Pahrump: murder - "An Indian was shot and killed by a man named Charles Clay at Pahrump Sunday night...officers and Indians are trying to capture Clay who is well armed." ["Johnnie," Beatty Bullfrog Miner, vol. 3, no. 27, September 28, 1907, p. 1, col. 3]

1907 Native Americans: Pahrump: Native American posse: Indian Charley - Rhyolite's sheriff took 20 armed Indians to apprehend the murderer of Little Charley, an Indian killed at the Pahrump ranch 80 miles south of Rhyolite. Charley had been employed at the ranch and lived at an Indian camp a mile away. [Bulffrog Miner, vol. 3, no. 27, September 28,1907 , p. 10, col. 3]

1907 Native American: Pahrump: murder - "Casey Got the Desperado: Pahrump Indian Killer Finally Arrested." [Rhyolite Daily Bulletin, vol. 1, no. 7, September 30, 1907, p. 3, col. 1] 
1907 Native American: Pahrump: employment: murder: Indian Charley - "The trial of Chas. Clay, who killed Indian Charley at Pahrump on Sept. 30, was commenced today before Judge Kalaher....Several witnesses were examined among them being two Indians from the Pahrump ranch who witnessed the affair." ["Preliminary of Charles Clay: Killing of Indian Charley at Pahrump Ranch is Being Investigated," Rhyolite Daily Bulletin, vol. 1, no. 10, October 3, 1907, p. 1, col. 2]

1907 Native Americans: Pahrump: murder - "A man named Ray is reported to have shot and killed and (sic) Indian at the White Ranch Tuesday. It is said to be the same Ray who was mixed up in a shooting scrape about a year ago... The Indians are on his trail and may lynch him, if officers are not present." ["Shooting at Manse," Beatty Bullfrog Miner, vol. 3, no. 28, October 5, 1907, p. 3, col. 2]

1907 Shoshones: Bulfrog area: pinyon nuts - A newspaper reported that the fall 190? pinyon nut crop was a failure. [Bullfrog Miner, vol. 4, no. 30, September 12, 1908, p. 6, col. 4]

1907 Paiutes: Nevada: funeral: ceremonies - Paiutes from all over Nevada assembled at Pyramid Lake for the funeral of Chief Natchez on February 8. [Beatty Bullfrog Miner, vol. 2, no. 50, March 2, 1907, p. 4, col. 2]

1907 Shoshones: Rhyolite: Panamint Joe Stuart - Watching the construction of a new office building in Rhyolite, Panamint Joe Stuart is reported to have squinted over his spectacles and shrugged "someday white man gone, Indian sleep here." [Lingenfelter, 1986:219]

1907 Fortymile Canyon: mining activities - A newspaper reported that the Fortymile Canyon section was highly mineralized and had many good springs. [Beatty Bullfrog Miner, vol. 4, no. 14, June 29, 1907, p. 2, col. 2]

1907 Ash Meadows: water resources - The Ash Meadows water system, under construction, would serve the Bullfrog district and other districts. It would have a 15milion gallon reservoir. [Bullfrog Miner, vol. 3, no. 9, May 24, 1907, p. 1, col. 1]

1907 Pioneer: boomtown - Gold was discovered in 1907 about seven miles north of Beatty. A boomtown developed, with a population of about 1,000 by 1909. (In 1909, a fire destroyed the town, which was never fully rebuilt.) [Kensler, nd:2-213]

1907 Oak Springs: mining activities - "John Doser and Herbert Llewellyn have returned from Oak Springs...They report good mineral and spring. Mr. Doser has some fine specimens of the ore bearing lead and silver at his office in Beatty." ["Oak Springs," Beatty Bullfrog Miner, vol. 2, no. 43, January 12, 1907, p. 2, col. 4]

1907 Fortymile Canyon: mining activities - John Doser and H.S. Llewellyn discovered "an old lead-silver mine" in Fortymile Canyon and opened three claims there. "Other prospectors have located in the immediate vicinity since the discovery became known and other finds have been made....Mr. Doser brought in with him the last time some of the tools used and left by the original workers. The make and character of these tell a story of old and amateur workmanship, but a pair of bellows, made entirely of canvass...is a curiosity and...could be used even today. A certain party in Beatty, while a resident of Eureka, Nevada, over twenty years ago, remember an outtit of Mexicans that made irregular trips into this country and returned with a string of animals loaded with silver ore identical in appearance with that of the old mine in Forty Mile." ["The Old Lead-Silver Mine of Forty Mile," Beatty Bulfrog Miner, vol. 2, no. 49, February 23, 1907, p. 2, col. 2] 
1907 Fortymile Canyon: mining activities - "Two men are working a good copper vein near Oak Springs...Copper, gold, silver, and lead abound in Forty Mile Canyon. Mr. Atwill has a ledge near Tipapan springs...A man named Holmes is working a good prospect near Tipapan Springs." ["Forty Mile," Beatty Bullfrog Miner, vol. 3, no. 14, June 29, 1907, p. 2, col. 2]

1907 Native Americans: Panamint Range - Clarence E. Eddy, "poet-prospector," claimed his party was attacked by wild Indians who told him "this is the Indians country." [Bullfrog Miner, vol. 3, no. 9, May 24, 1907, p. 1, col. 1]

1907 Native Americans: Panamint Range: Native American prospecting - As Clarence Eddy encroached on their resources, "a few Indians went to Greenwater, brought back some white men they knew, and pointed out to them a 2-foot-wide lode...and located within 100 feet of Eddy's gold-and-silver-producing Red Mammoth Claim. The Greenwater people were so enthused they stayed day and night extracting and shipping the ore, which was practically in a natural state, having been crudely 'blasted' out by Indians years ago... This property, known hereafter as the "Indian Strike," was later expected to be bonded for $\$ 100,000$." Another version of this story is that one member of the tribe was dispatched to Greenwater to get heip in legally holding the ground. A Judge L.O. Ray, president of the Rhyolite Mining and Brokerage Company, who was then in town, accompanied the Native American back, along with a Henry Brown and a George Fairbanks, in return for one-fourth interest in the claims. [Greene, 1981:374-375]

1907 Native American: Grapevine Range: guides - Walter Scott, traveling from Death Valley to Rhyolite, was accompanied by two men, one of them a Native American. [Bullfrog Miner, vol. 3, no. 12, June 15, 1907, inside p., col. 5]

1907 Native Americans: Panamint Range: Native American mineral claims - Native Americans claimed Clarence Eddy was encroaching on their prior discovery. They brought white friends from Greenwater to support their claims. [Bullfrog Miner, vol. 3, no. 15, July 8, 1907, inside p., col. 3]

1907 Paiutes: Lida: employment: mining activities: wood haulers - "John and Sammy Best, two Paiute Indian wood haulers of Lida, Esmeralda county, are now reported to be possessed of a fortune, having sold a mine which they accidentally discovered while hauling wood...The mine is known as the Geraldine....Charles Kollogg, an old-time prospector who lived with his Indian wife near the head of Smoky Valley, Lander county, sold several rich claims recently for $\$ 30,000$, and on his death the Paiute woman has inherited the estate." [Searchlight, vol. 6, no. 23, November 8, 1907, p. 3, col. 6]

1907 Rhyolite: population - The Rhyolite Herald editor estimated a population of 3,000 in May 1907. [Weight and Weight, 1985:18]

1907 Rhyolite: Labor Day picnic - A Labor Day picnic was held at Howell's ranch, some 12 miles north of Rhyolite. Approximately 1,500 attended. [Bullfrog Miner, vol. 3, no. 24, September 7, 1907, p. 10, col. 5]

1907 Ash Meadows: water resources - A corporation acquired the water supply at Ash Meadows, with a flow of 12 millions gallons a day. [Rhyolite Herald, vol. 2, no. 40, February 1, 1907, inside p., col. 3] 
1907 Oasis Valley: water resources - Rhyolite's water supply systems drew water from Goss Springs (The Bullfrog Line) and from the "innumerable springs of the Beatty ranch" (The Patrick Line). [Bullfrog Miner, vol. 3, no. 1, March 29, 1907, p. 7, col. 2]

1907 Rhyolite: railroads - Rhyolite was the distributing point for supplies for various tributary camps. [Bullfrog Miner, vol. 3, no. 39, December 21, 1907, p. 14, col. 3]

1907 Transvaal: mining activities - Several companies were involved in development work in the Transvaal district, 20 miles northeast of Rhyolite. [Bulffrog Miner, vol. 3, no. 1, March 29, 1907, p. 3, col. 1]

1907 Bare Mountain: mining activities - Ore was discovered on Bare Mountain's western slope, about one mile from the Clark Railroad. [Bullfrog Miner, vol. 3, no. 33, November 9, 1907, inside p., col. 3]

1907 Goldfield: population - Goldfield had a population over 20,000. [Pippin and Zerga, 1983:58]

1907 Bullfrog district: mining activities - The largest mines during 1907-11 were the Montgomery-Shoshone with a gross yield of $\$ 1,388,398$ and the Shoshone-Polaris with $\$ 101,081$. [Couch and Carpenter, 1943:118]

1908

1908 Shoshones: Beatty: Panamints: Native American mining claims: Panamint Joe Stuart - "Panamint Joe Stuart, the chief of the Shoshones, who with S. Park of Beatty owns four claims about six miles south of Telescope Peak in the Panamint range, accompanied by M.T. Hubbard, the mining engineer, returned a few days ago from the property....'Injun man got heap good ore' says Joe....It seems that the discovery was originally made by Joe, the Shoshone chief, and he allowed Mr. Park to do the locating for a half interest....Joe is rapidly coming to the front as a mining man of importance. In addition to the Kismet claims in the Panamints...Joe and his associates have another group of nine claims about 15 miles from the first locations. Joe is exhibiting some ore in Rhyolite from the property.... There is no doubt about the specimens being rich, and if Joe has the amount of ore he says he has, he is destined to become the richest "old Injun man" in the country. S. Park of Beatty and two others are interested with him in the locations." ["Heap Old Injun Man Has Good Locations," Bullfrog Miner, vol. 4, no. 12, June 13, 1908, p. 5, col. 3]

1908 Native Americans: Bullfrog: dance performance - "A few remnants of the once powerful Paiute tribe of Indians, gathered in a tent near the Bullfrog corral last night and gave an entertainment to a large number of white people. The affair lasted until nearly midnight." ["Paiute Indians Hold Pow Wow," Rhyolite Daily Bulletin, vol. 1, no. 178, April 20, 1908, p. 1, col. 1]

1908 Shoshones: Bullfrog: dance performance: Panamint Joe Stuart - "Panamint Joe Stuart led a 'war dance' near Clark's corral and agreed to repeat the event the next night ('[s]cant remnant of a once mighty tribe')." Panamint Joe had just completed a week's stand at Beatty, "his former stronghold and headquarters of his tribe." ["Panamint Joseph Gives War Dance at Bullfrog," Bullfrog Miner, vol. 4, no. 5, April 25, 1908, p. 8, col. 3] 
1908 Shoshones: Rhyolite: dance performance: Fourth of July: Panamint Joe Stuart Panamint Joe Stuart and his tribe of "wild Indians" were scheduled to pertorm a "genuine war dance" after the Fourth of July program at the opera house. ["Plans for the Fourth," Rhyolite Herald, vol. 4, no. 8, June 17, 1908, p. 5, col. 5]

1908 Native Americans: Rhyolite: Fourth of July: sports - The Fourth of July program included a "Squaw Race, prize \$10." [Bullfrog Miner, vol. 4, no. 14, June 27, 1908]

1908 Native Americans: Rhyolite: Fourth of July: dance performance: Panamint Joe Stuart - Panamint Joe Stuart was scheduled to present "one of the greatest war hops in history.... Half a dozen professional dancers are expected from Idaho to join the dancers." [Bullfrog Miner, vol. 4, no. 13, June 20, 1908, p. 8, col. 3]

1908 Shoshones: Rhyolite: Fourth of July: dance performance: sports: Panamint Joe Stuart - The Fourth of July sports program included a "squaw race." The evening program included a "Grand Shoshone war dance, conducted by Chief-Rain-in-theface Gwynne" assisted by Panamint Joe Stuart "and the twenty warriors of the tribe" from 8:30-9:30 p.m. [Rhyolite Herald, vol. 4, no. 10, July 1, 1908, p. 10, col. 4]

1908 Native Americans: Rhyolite: Fourth of July: dance performance: Panamint Joe Stuart - The Fourth of July program included a "Grand Shoshone War Dance," conducted by Panamint Joe Stuart. [Bullfrog Miner, vol. 4, no. 15, July 4, 1908, p. 6. col. 3]

1908 Native Americans: Rhyolite: dance performance - "A few of the straggling remnants of the once powerful Paiute tribe of Indians gave a second entertainment near the baseball grounds last night and a large crowd witnessed the maneuvers of the once masters of the desert." ["Indians Hold Another Powwow," Rhyolite Daily Bulletin, vol. 1, no. 228, October 7, 1908, p. 4, col. 1]

1908 Native Americans: Rhyolite: sports: Panamint Joe Stuart: Fourth of July - The winner of the Fourth of July squaw race was Julia Jackrabbit. Mayme Sidewinder received the second prize. Panamint Joe Stuart was one of the runners in the 70-yard dash for men over 50. [Bullfrog Miner, vol. 4, no. 16, July 11, 1908, p. 5, col. 3]

1908 Native Americans: Rhyolite: pinyon nuts - Native Americans in Rhyolite had predicted a mild winter and hot summer followed by a poor pinyon nut harvest. The fall 1907 pinyon crop was small, as predicted. ["No Heap Pine Nuts, No Heap Cold; No Heap Cold, Heap Hot," Bullfrog Miner, vol. 4, no. 18, July 23, 1908, p. 8, col. 1]

1908 Shoshones: Bullfrog area: pinyon nuts: Panamint Joe Stuart - The fall 1908 pinyon nut crop was a failure, according to Panamint Joe Stuart. [Bullfrog Miner, vol. 4, no. 24, September 12, 1908, p. 6, col. 4]

1908 Shoshones: Bullfrog area: weather forecast: Panamint Joe Stuart - Panamint Joe Stuart predicted a mild winter. His prediction for a mild winter the previous year had been accurate. The newspaper characterized "Indian weather theory" as "[n]o heap pinenuts, no heap cold"; and as "no heap cold, heap hot." [Bullfrog Miner, vol. 4, no. 30, September 12, 1908, p. 6, col. 4] 
1908 Shoshones: Rhyolite: camp: Panamint Joe Stuart - There was an apparent murder at a Native American camp near the Indian Springs water camp north of Rhyolite. Panamint Joe Stuart said he had no information about any trouble or killing there. [Bullfrog Miner, vol. 4, no. 29, October 17, 1908, p. 8, col. 5]

1908 Shoshones: Rhyolite: Panamint Joe Stuart - The diary of Jeanne E. Wier records that she arrived in Rhyolite on October 23, 1908. On October 24, she recorded "[t]his P.M. interviewed Panamint Joe, Chief of the Shoshones." On October 25, she took the train from Rhyolite to Beatty. [Wier, 1961:19]

1908 Native Americans: Rhyolite: camp - "The Indian camp on the flat a little north of Rhyolite was the scene of a sanguinary encounter the other day....Two Paiute braves, Poison Oak and Running Horse, both fell in love with a copper colored damsel, Weeping Willow...and as maidens of marriageable age are not plentiful among the Paiutes, the rivaly soon became something fierce....picking a time when Panamint Joe, the big chief of the Paiutes in this section was absent, Running Horse and Poison Oak agreed to battle to the death....they moved a short distance from camp, and with the squaws and children looking wonderingly on, the battle began....The only warrior in the camp besides the combatants was Little Stinking Skunk - the pet Paiute discovered by Abe Gwynne....A canvas was thrown over the fallen Indian [Poison Oak] and when white passersby...asked what was the matter, were gruffly told, "[h]e no dead, only dead drunk." The next morning the body was placed in a wagon and, accompanied by a group of warriors, started west to the wooded hills.... Little Stinking Skunk is now ostracized by his fellow Indians for his cowardice. They will have none of him and he must go forth a wanderer, lonely and disconsolate...And thus passeth the chance of Mrs. Stinking of ever becoming the leader of the Paiute ' 400 ' and poor 'Abe' is heartbroken." ["Duel to Death Between Enraged Indians," Rhyolite Daily Bulletin, vol. 1, no. 233, October 13, 1908, p. 1, col. 1]

1908 Native Americans: Rhyolite: camp - "The law against giving or selling Indians liquor should be enforced in Rhyolite, and at once, as its use has caused the bunch of redskins camped in the north end of town to become a veritable nuisance. The other evening Constable Hofmann rounded up the entire camp, who had been quarreling and fighting for some time, and put them in jail...Besides fighting among themselves the Indians have scared women and children living in the north end of town several times, and complaints of their conduct has been made. They should be moved to a more isolated neighborhood." ["Indians in Jail for Raising a Disturbance," Rhyolite Daily Bulletin, vol. 1, no. 294, December 26, 1908, p. 4, col. 1]

1908 Native Americans: Oasis Valley: intermamiage of Native Americans and Euroamericans - The obituary of M.M. Beatty refers to him as 'Old Man' and comments that "with his demise there passes from out the Amargosa desert the last of the race of 'squaw men', of whom M.M. Beatty was a notable character. 'Old Man' Beatty resided in this section for more than thirty years, we are told. He came here many years before the first sign of civilization, and lived among the Shoshone Indians, taking a young squaw for his wife. He raised a family of children, engaged in business pursuits when the onward march of civilization sought him out in his lonely haunts, and, building a splendid home in the town of Beatty, 
there maintained his household, with the squaw wife as his queen. Unlike many other white men who had lived with squaw wives for years, 'Old Man' Beatty did not desert his red-faced companion when the country began to settle up. When fortune favored him by the sale of property, he provided a home for her just like the white men provided homes for their wives and families, and gave his family all of the comforts that his fortune could afford. Whatever may have been the faults of this hardy pioneer, his devotion to his squaw and his children evidenced a manly virtue." ["The Last of the Squaw Men," Rhyolite Herald, vol. 4, no. 34, December 16, 1908, inside p., col. 3]

1908 Native Americans: Oasis Valley: intermanriage of Native Americans and Euroamericans - The obituary of M.M. Beatty incorrectly identified him as the first white man in the 'Bullfrog district.' "He lived at Beatty ranch, a half mile from town and was known as a 'squaw' man, since his wife was a full-blood Indian. Beatty left 4 children." [Bullfrog Miner, vol. 4, no. 38, December 19, 1908, p. 8, col. 5]

1908 Native Americans: Inyo: Native American claims - Panamint Joe, Wild Bill, and Amargosa Albert accompanied S. Park and Deputy Surveyor Hubbard of Rhyolite to survey mining properties in the Inyo area. ["Indians and Mining," Beatty Bullfrog Miner, vol. 4, no. 13, June 20, 1908, p. 4, col. 2]

1908 Native American: Native American prospecting: Native American mining claims A Native American made the first find of gold on Bowman's Creek (five miles south of old Kingston on the west side of the upper Smoky Valley). [Rhyolite Herald, vol. 4, no. 9, June 24, 1908, p. 7$]$

1908 Native American: Oasis Valley: village: water resources - A newspaper reported "archaeological" evidence of an "ancient Indian camp" near the water supply of the California Bullfrog Company. "There is a tradition that the gulch below the camping ground once flowed with water." [Bullfrog Miner, vol. 4, no. 4, April 18, 1908, p. 5, col. 1]

1908 Native Americans: Nevada: mining activities - A newspaper editor noted that Native Americans were willing to cooperate with Euroamerican miners, combining Native American knowledge of the terrain with Euroamerican knowledge of financial and legal affairs. ["Indians and Mining," Beatty Bullfrog Miner, vol. 4, no. 13, June 20, 1908, p. 4, col. 2]

1908 Oasis Valley: water resources: land claims - Litigation over the Beatty ranch, involving the Patrick water line running into Rhyolite, was ruled upon by the General Land Otfice in Washington. The decision ruled against the claims of the water company, reversing an earlier decision by the land office at Carson City and affirming the claims of parties named Groshong and Garberg. The Patrick water company bought the ranch and its water rights from M.M. Beatty, "who had squatted there many years before, but had never perfected his title." Later Groshong and Garberg of Beatty filed claims under the homestead laws, and the case was tried at Carson. ["Beatty Ranch Case Has Been Decided Again," Rhyolite Daily Bulletin, vol. 1, no. 228, October 7, 1908, p. 1, col. 3.]

1908 Rhyolite area: timber - A newspaper article reported that govemment timberlands in the Grapevine Mountains had been denuded for fuel for Rhyolite and that timberlands in the Kingston and Charleston Mountain regions had also been denuded. [Bulffrog Miner, vol. 3, no. 47, February 15, 1908, p. 1, col. 6] 
1908 Rhyolite: railroad - Rhyolite was no longer a stub line of the Tonopah and Tidewater Railroad. It was now on the main line. [Bullfrog Miner, vol. 4, no. 17, July 18, 1908, p. 2, col. 5]

1908 Fortymile Canyon: mining activities - "Robert Browne was in town Thursday after supplies for his camp at Forty Mile. He has several men working on a good prospect in the Calico hills, 20 miles north of Canyon siding." ["Forty Mile," Beatty Bullfrog Miner, vol. 4, no. 27, September 26, 1908, p. 1, col. 2]

1908 Fortymile Canyon: mining activities - Miners struck gold at the Maxine mine, 15 miles east of Fortymile Canyon. ["Good-Strike Near 40-Mile Canyon," Rhyolite Herald, vol. 4, no. 34, December 16, 1908, inside p., col. 1]

1908 Fluorine: mining activities - There was a new camp at the Diamond Queen mine (12 miles east of Bulfrog and 15 miles northeast of Beatty) with a population around 300. A road from Beatty was under construction. [Bulffrog Miner, vol. 4, no. 4, April 18, 1908, p. 1, col. 6]

1908 Mining: Fluorine: mining activities: road - A stage line ran to a new camp at Fluorine. [Beatty Bullfrog Miner, vol. 4, no. 6, May 2, 1908, p. 2, col. 1]

1908 Telluride: mining activities - A new mining camp called Telluride was located a few miles north of Fluorine. [Rhyolite Herald, vol. 4, no. 4, May 20, 1908, inside p., col 1]

1908 Bulfrog district: mining activities - Mining activity was underway in the section around Fluorine and Diamond Queen, with construction of roads, shafts, and crosscuts at numerous mines. [Rhyolite Herald, vol. 4, no. 2, May 6, 1908, inside p., col. 6]

1908 Bare Mountain: mining activities - According to a newspaper, the Transvaal/ Diamond Queen area east and northeast of Beatty was "teaming with mines and prospects." The Diamond Queen was nine miles southeast of Beatty, the Transvaal was fifteen miles northeast, and the Bon Ton and Oasis were ten miles north. [Beatty Bullfrog Miner, vol. 4, no. 6, May 2, 1908, p. 2, col. 1]

1908 Bullfrog district: mining activities - At least 357 miners were on the payrolls of mines in the Bulffrog district. [Bullfrog Miner, vol. 4, no. 12, June 13, 1908, inside p., col. 3]

1908 Diamond Queen: mining activities - Ore shipments were being made. [Beatty Bullfrog Miner, vol. 4, no. 6, May 2, 1908, p. 2, col. 1]

1908 Mining: Fluorine district - Mercury was discovered. [Kral, 1957:60]

1908 Jamestown: mining activities - There was a new camp 32 miles southeast of Goldfield. [Bullfrog Miner, vol. 4, no. 5, April 25, 1908, p. 4, col. 6]

1909

1909 Shoshones: Pahrump: murder: Ash Meadows Charley: Black family: Indian Henry - Indian Henry, brother of Mrs. Beatty, was killed in Pahrump by a Shoshone man named John Scott, who was the son of Ash Meadows Charley. "Indian Henry, an old-time Shoshone Indian, and a brother of Mrs. Beatty, was killed at Parump on last Sunday by a fellow tribesman. The deceased was paying the penalty of a 
violation of Indian customs and traditions. He was slayed by John Scott, the son of Ash Meadow Charley, probably aided by one Ed Brusse.... Brusse was arrested at White's ranch, while Scott was captured at Ash Meadows. Both of the captives talk good English (sic)....Scott is a bad Indian. He bears a reputation among his kind as being a strange one.... There is a custom among Indians to burn all of the personal property of any member of the tribe who dies a violent death. There was a killing in the family of Bob Black some time ago. At this time Henry had possession of a wagon that belonged to Bob. He never turned this in for destruction or destroyed it himself. This act got him in bad with the Indians of his neighborhood. Scott, in particular, was very jealous of Henry's use of the Black wagon. For this reason, he is reported to have sworn to kill him...." [Bulfrog Miner, vol. 5, no. 18, July 24, 1909, p. 4, col. 1]

1909 Shoshones: Pahrump: murder: Indian Henry - Indian Henry was killed near Pahrump ranch by two other Native Americans (John Scott and Ed Bruce). The murder was attributed to drunkenness. Scott and Bruce were taken to the Rhyolite jail. [Rhyolite Herald, vol. 5, no. 13, July 24, 1909, p. 1, col. 3]

1909 Shoshones: Pahrump: settlement: murder: Indian Henry - The coroner's inquest found that Indian Henry of Pahrump died of wounds inflicted by John Scott and Ed Bruce. Witnesses included several Native Americans living in Pahrump, including Joe Lake, Nancy Tecopa, and "Indian Henry's wife." [Inquest file, Nye County Recorder's Office, document dated July 20, 1909]

1909 Shoshones: Rhyolite: interactions between Native Americans and Euroamericans: Panamint Joe Stuart: guides - "Panamint Joe, 'chief' of the Shoshone Indians which frequented Rhyolite during the boom days, proved himself a real hero, giving up his life in an unsuccessful effort to take water to a party of white people stranded in the vicinity of Emigrant Canyon on the south side of Death Valley. ...For many years after his death, his widow Maggie was pensioned by E.A. (Bob) Montgomery...in appreciation for Panamint Joe's heroic sacrifice." [Ritter, 1982:14]

1909 Shoshones: Rhyolite: Death Valley: guide: Panamint Joe Stuart: Maggie Stuart Panamint Joe Stuart, his wife Maggie, and their "papoose" guided a party of five Euroamericans across Death Valley from Rhyolite to Skidoo. The mules died in the heat. Panamint Joe became ill, apparently after eating some canned meat. His wife and two Euroamerican men went to get water and help. Maggie returned with water from Emigrant Springs, but to no avail. Panamint Joe died and was buried five miles from the Springs. His wife returned to the springs to keep the three white women supplied with water. [Rhyolite Herald, vol. 5, no. 13, July 24, 1909, inside p., col. 4]

1909 Shoshone: Beatty: guide: Panamint Joe Stuart. Maggie Stuart - Panamint Joe Stuart and his wife Maggie guided a party of travelers from Rhyolite on its way to Skidoo. "In the party were Mr. and Mrs. J. Parks of Beatty, a man named Worden and his grown-up daughter, and another man named Zemki. The party was under the guidance of Panamint Joe, for twenty years well known among mining men... On the morning of the third day, Panamint Joe ate a large portion of uncooked ham...In less than five hours...Joe had died. Panic seized the white people, and they immediately jumped upon the causes...leaving Maggie to trail along as 
best she might. The heat, lack of water and the strangeness of the silent vastness...caused the white people to overdrive their animals...the animals finally perished...Hours after they had come to a halt Maggie quietly slipped into camp." Maggie pointed the men toward Emigrant Springs, but they wandered lost for three days until finally finding the springs. That same night Maggie arrived at the spring. "For three days Maggie traveled twice each day to the water...It was only her hardness and bravery that enabled the women to live." After some days of recuperation, two of the men continued to Skidoo. When finally rescued, "the two white women...were nearly dead and Miss Worden had entirely lost her mind." [Owens Valley Herald, vol. 1, no. 6, July 9, 1909, p. 2, entire]

1909 Shoshone: Beatty: drinking: Panamint Joe Stuart: Maggie Stuart - Maggie, Panamint Joe Stuart's widow, received money from Bob Montgomery after the death of her husband. After receiving the money, she bought whiskey, got drunk, and got into a fight in Beatty. Panamint Joe's nephew Tom Stuart went to the newspaper office and dictated a letter to Bob Montgomery asking him to send her support money in credit rather than in cash to prevent her from buying liquor. [Rhyolite Herald, vol. 5, no. 21, September 18, 1909, p. 2, col. 2]

1909 Shoshone: Bullfrog district: Native American prospecting: Panamint Joe Stuart Bob Montgomery was a friend of Panamint Joe Stuart. Panamint Joe helped Montgomery in the discovery of the Montgomery Shoshone mine and in protecting Montgomery's interest. From this partnership came the name, the MontgomeryShoshone mine. "Montgomery assured that Joe never wanted for anything and likewise provided for Joe's wife after Joe's death." [Rhyolite Herald, vol. 5, no. 13, July 24, 1909, inside p., col. 4]

1909 Shoshone: Beatty: guide: Panamint Joe Stuart: Maggie Stuart - A Euroamerican man in the party guided by Panamint Joe Stuart and his wife Maggie across Death Valley claimed that Maggie did not act altruistically. He said Panamint Joe and Maggie rode ponies while the white women in the party had to walk. He also claimed that Maggie demanded money before bringing the stranded women water. [Rhyolite Herald, vol. 5, no. 25, October 16, 1909, inside p., col. 3]

1909 Pahrump: agriculture - Pahrump ranch (10,000 acres, with 800 cultivated acres) provided vegetables and fruit to Rhyolite. White's ranch was six miles to the southeast. [Rhyolite Herald, vol. 5, no. 21, September 18, 1909, p. 1, col. 2]

1909 Native Americans: Pahrump: agriculture - "A number of Indians are employed" in the cultivation of Pahrump ranch. [Mendenhall, 1909:91]

1909 Native American: Oasis Valley: Native American Camp - A map in Mendenhall (1909) shows a Native American camp northeast of Springdale. [Mendenhall, 1909:map]

1909 Native Americans: Pioneer - "Three Indians have made their appearance in camp and are intimidating some of our tame canines." ["Pioneer Topics," Pioneer Topics, vol. 1, no. 7, April 1, 1909, p. 1, col. 6]

1909 Amargosa Valley: agriculture - The farms and ranches between Beatty and Springdale included those of J.A. Knight (160 acres), L.S. Burrel (160 acres), A.P. Garberg (160 acres), L.L. Williams, Jack Castle, Jake Eck, Jesse Kline, H.W. Groshong, J.W. Ewing, and Mr. Johnson. [Rhyolite Herald, vol. 5, no. 19, September 4, 1909, inside p., col. 2] 
1909 Rhyolite: oil - Oil discoveries were made at Indian Springs, north of Rhyolite. [Bullfrog Miner, vol. 4, no. 40, January 2, 1909, p. 6, col. 3]

1909 Pioneer: mining activities - The new camp of Pioneer in the Bullfrog district had a population of 2,500. [Lingenfelter, 1986:230]

1909 Johnnie district: mining activities - There was steady production in the Johnnie district from 1909-11. [Lingenfelter, 1986:358]

1909 Fortymile Canyon: Cane Spring: stage roads - A 1909 map made by a government geological surveyor shows a road following Fortymile Canyon and then slanting eastward to Tippipah Spring; another road crossing Crater Flat and Jackass Flat north of Skull Mountain; and several roads converging on Cane Spring, including one from Cane Spring to Toboban Spring on Shoshone Mountain. [Mendenhall, 1909:map]

1910

1910 Nye County: population - The 1910 census enumerated a total population of 7,513 for Nye County. Population of precincts in the vicinity of the study area were as follows:

a. Beatty precinct, 122.

b. Florine precinct, 32 .

c. Johnnie precinct, 179 .

d. Springdale precinct, 231 .

The total Native American population of Nye County, according to the 1910 census, was 523 (up from 372 in 1900). Note: the census totals omitted the Rhyolite precinct, although the detailed census enumeration for Nye County included a census of Rhyolite (see next entry). Note also that both the 1900 and 1910 censuses missed the boom years of population in the Rhyolite and Oasis Valley area. [Bureau of the Census, 1913a:79,86]

1910 Shoshones: Paiutes: southern Nye County: population - The 1910 Nevada census provided a detailed enumeration of Native Americans, including names, tribal aftiliations, and occupations, for the following precincts around the study area:

a. Rhyolite precinct.

b. Springdale precinct (apparently encompassing the Oasis Valley north of Beatty).

c. Johnnie precinct (apparently encompassing Ash Meadows and Pahrump).

Thity Native American people are enumerated for Springdale precinct, ten for Rhyolite precinct, and fifty-four for Johnnie precinct. No Native Americans are listed in the census for Beatty precinct. Evidently Beatty area Native American people were either away from the locality at the time of the census, or were enumerated as part of the Springdale precinct. For details, see Table 5.

All the Native American people in Rhyolite precinct were identified as Shoshone, with listed occupations including basket weaver (2), woodcutter (2), and "none" (5). 
Table 5. 1910 Census Data on Native American People in Southern Nye Countya (Page 1 of 4)

\begin{tabular}{|c|c|c|c|c|c|c|c|}
\hline Name, Rel. to $\mathrm{HOH}$ & G A & $\begin{array}{l}\text { Mar } \\
C Y\end{array}$ & $\begin{array}{l}\text { Child } \\
\text { D N }\end{array}$ & Jccupation & $\begin{array}{l}\text { Language } \\
\text { RWS }\end{array}$ & & $\begin{array}{l}\text { Ethnic } \\
\text { E F M }\end{array}$ \\
\hline $\begin{array}{l}\text { Charlle Meadows } \\
\text { ?, Wife } \\
\text { John, Son } \\
\text { Dan, Son } \\
\text { Winters, Son } \\
\text { Hawley, Son } \\
\text { Annie, Dau } \\
\text { Hannah, Dau } \\
\text { Ubehebe (?), Niece } \\
\text { Gerogh, Nephew } \\
\text { John Hughes } \\
\text { Jim Ash } \\
\text { Lucy, Wife } \\
\text { Charlle Chapeau } \\
\text { Liza Kearney } \\
\text {-, Son } \\
\text {-, Son } \\
\text {-, Dau } \\
\text { Mary Scott } \\
\text { Higgens } \\
\text { Albert Howells } \\
\text { Sports?, Wite } \\
\text { Tecopa Charles } \\
\text { Dan Meadows } \\
\text { Annie, Wife } \\
\text { Billy, Son } \\
\text { Jones } \\
\text { Dave Jenks } \\
\text { Charlie Howells } \\
\text { Minnle Smlth } \\
\text { Vintah?, Son } \\
\text { Tonopah, Son } \\
\text { White Tim, Brother } \\
\text { Johnnle Pahwean (?) } \\
\text { Susie, Wife } \\
\text { Georgh, Son } \\
\text { Dennis Kearney } \\
\text { Paprah, Wife } \\
\text { Mary, Dau } \\
\text { Man }\end{array}$ & $\begin{array}{l}M, 84 \\
F, 65 \\
M, 31 \\
M, 27 \\
M, 24 \\
M, 19 \\
F, 32 \\
F, 29 \\
F, 14 \\
M, 12 \\
M, 35 \\
M, 65 \\
F, 63 \\
M, 25 \\
F, 41 \\
M, 6 \\
M, 4 \\
F, 3 \\
F, 47 \\
M, 55 \\
M, 39 \\
F, 39 \\
M, 35 \\
M, 26 \\
F, 27 \\
M, ? \\
M, 25 \\
M, 26 \\
M, 27 \\
F, 26 \\
M, 4 \\
M, 1 \\
M, 5 \\
M, 28 \\
F, 18 \\
M, ? \\
M, 47 \\
F, 22 \\
F, 1 / 2\end{array}$ & 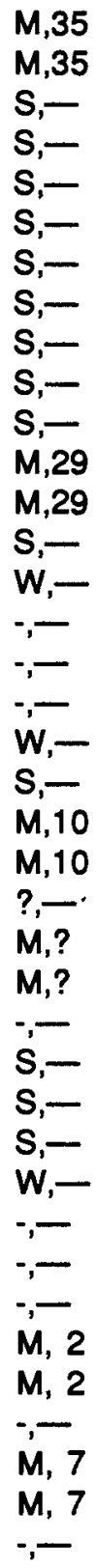 & 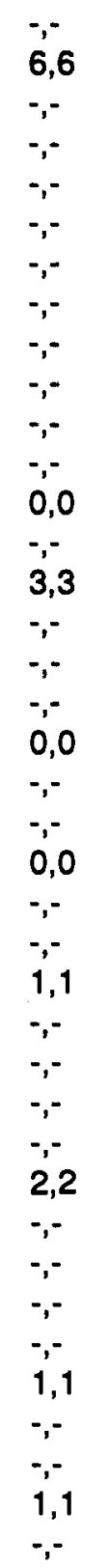 & $\begin{array}{l}\text { Farmer } \\
\text { None } \\
\text { Farmer } \\
\text { Farmer } \\
\text { Farmer } \\
\text { Farmer } \\
\text { Farmer } \\
\text { Farmer } \\
\\
\text { Farmer } \\
\text { Farmer } \\
\text { Farmer } \\
\text { Farmer } \\
\text { Farmer } \\
\\
\\
\text { Farmer } \\
\text { Farmer } \\
\text { Farm Labor } \\
\text { None } \\
\text { Farm Labor } \\
\text { Farm Labor } \\
\text { None } \\
\text { Farm Labor } \\
\text { Farm Labor } \\
\text { Farm Labor } \\
\text { None } \\
\\
\\
\text { Farm Labor } \\
\text { None } \\
\text { Farm Labor } \\
\text { None } \\
\end{array}$ & 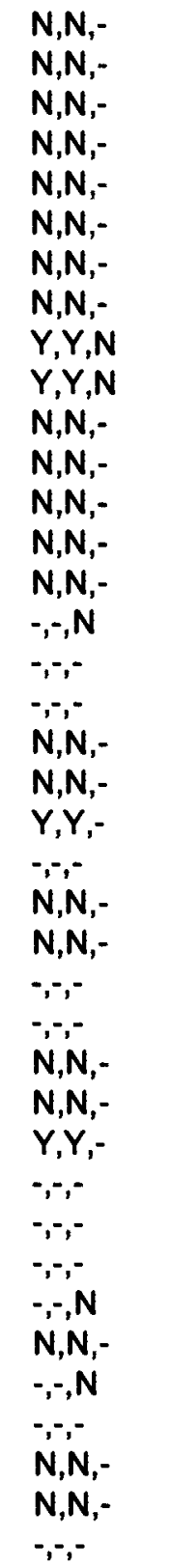 & 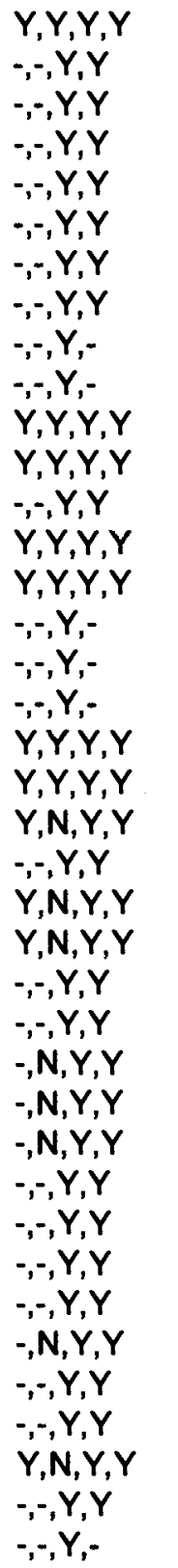 & 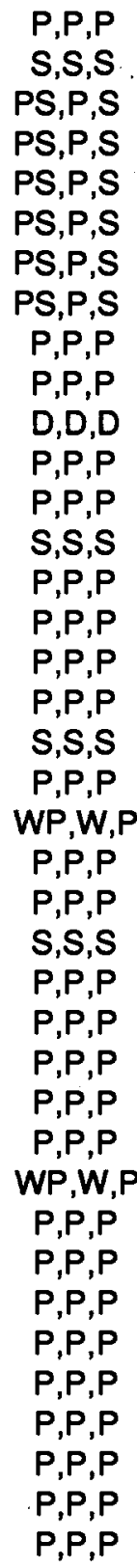 \\
\hline
\end{tabular}


Table 5. 1910 Census Data on Native American People in Southern Nye Countya (Page 2 of 4)

\begin{tabular}{|c|c|c|c|c|c|c|c|}
\hline Name, Rel. to $\mathrm{HOH}$ & G A & $\begin{array}{l}\text { Mar } \\
\text { C Y }\end{array}$ & $\begin{array}{l}\text { Child } \\
\text { D N }\end{array}$ & Occupation & $\begin{array}{l}\text { Language } \\
\text { RWS }\end{array}$ & $\begin{array}{l}\text { Economic } \\
\text { HXAT }\end{array}$ & $\begin{array}{l}\text { Ethnic } \\
\text { E F M }\end{array}$ \\
\hline $\begin{array}{l}\text { Nellie, Dau } \\
\text { Johnnie, Son } \\
\text { Jim Smith } \\
\text { Hootscot?, Wife } \\
\text { Snooks (?), Dau } \\
\text { Pete, Son } \\
\text { Ike Manse } \\
\text { Minnle Ute } \\
\text { Jon Lasee (?) } \\
\text { Nellie, Wife } \\
\text { Louis, Son } \\
\text {-, Son } \\
\text {-, Son } \\
\text { Loulse Tecopa } \\
\text {-, Son }\end{array}$ & $\begin{array}{l}F, 6 \\
M, 3 \\
M, 26 \\
F, 21 \\
F, 5 \\
M, 3 \\
M, 32 \\
F, 35 \\
M, 35 \\
F, 32 \\
M, 5 \\
M, 2 \\
M, 1 \\
F, 35 \\
M, 20\end{array}$ & $\begin{array}{l}:-- \\
:-, \\
M, 6 \\
M, 6 \\
:-- \\
:-, \\
S,- \\
S,- \\
M, 7 \\
M, 7 \\
:-- \\
:- \\
:- \\
W,- \\
S,-\end{array}$ & $\begin{array}{l}\because- \\
\because,- \\
\because- \\
\because- \\
\because- \\
\because- \\
\because- \\
\because- \\
\because- \\
3,3 \\
\because- \\
\because- \\
\because- \\
2,1 \\
\because-\end{array}$ & $\begin{array}{l}\overline{ } \\
\text { Farm Labor } \\
\text { None } \\
\overline{-} \\
\text { Farm Labor } \\
\text { None } \\
\text { Farmer } \\
\text { Farmer } \\
\square \\
\overline{\text { Farmer }} \\
\text { Farmer }\end{array}$ & 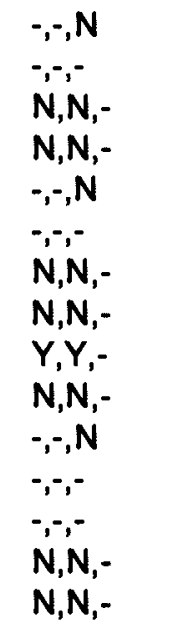 & $\begin{array}{l}-,-, Y,- \\
\because,-, Y,- \\
Y, N, Y, Y \\
\because \because, Y, Y \\
\because \because, Y,- \\
\because \because, Y,- \\
Y, N, Y, Y \\
Y, N, Y, Y \\
Y, Y, Y, Y \\
\because \because, Y, Y \\
\because, Y, Y,- \\
\because \because, Y,-- \\
\because, Y, Y,- \\
Y, Y, Y, Y \\
\because-, Y, Y\end{array}$ & $\begin{array}{c}P, P, P \\
P, P, P \\
P, P, P \\
P, P, P \\
P, P, P \\
P, P, P \\
P, P, P \\
P, P, P \\
\text { SW,W,S } \\
\text { S,S,S } \\
\text { S,S,S } \\
\text { S,S,S } \\
\text { S,S,S } \\
\text { P,P,P } \\
\text { P,P,P }\end{array}$ \\
\hline
\end{tabular}

Springdale Census Precinct (in Oasis Valley)

\begin{tabular}{|c|c|c|c|c|c|c|c|}
\hline $\begin{array}{l}\text { Tom Stewart } \\
\text { Pahiveib, Wife } \\
\text { Jerry, Son } \\
\text { May, Dau } \\
\text {-, Dau } \\
\text { George Bollna } \\
\text { Dixie, Wife } \\
\text {-, Son } \\
\text {-, Dau } \\
\text { Mary, Sister } \\
\text { Susle } \\
\text { George Roberts } \\
\text {-, Wife } \\
\text { Frank Kennedy } \\
\text { Bob Thompson } \\
\text { Minnie, Wife } \\
\text {-, Dau } \\
\text { Jon Kennedy } \\
\text { Rosle } \\
\text { John }\end{array}$ & $\begin{array}{l}M, 41 \\
F, 35 \\
M, 9 \\
F, 7 \\
F, 2 \\
M, 25 \\
F, 20 \\
M, 2 \\
F, 1 \\
F, 15 \\
F, 90 \\
M, 32 \\
F, 25 \\
M, 54 \\
M, 29 \\
M, 21 \\
F, 1 \\
M, 25 \\
F, 19 \\
M, 80\end{array}$ & $\begin{array}{l}M, 20 \\
M, 20 \\
:,- \\
:,- \\
:,- \\
M, 3 \\
M, 3 \\
:-, \\
:-, \\
S,- \\
W,- \\
M, 2 \\
M, 2 \\
?,- \\
M, 4 \\
M, 4 \\
:-, \\
S,- \\
S,- \\
W,-\end{array}$ & $\begin{array}{l}\because- \\
3,3 \\
\because-, \\
\because- \\
\because- \\
\because- \\
2,2 \\
\because- \\
\because- \\
\because- \\
3,2 \\
\because- \\
0,0 \\
\because- \\
\because- \\
1,1 \\
\because- \\
\because- \\
\because- \\
\because-\end{array}$ & $\begin{array}{l}\text { Farm Labor } \\
\text { None } \\
- \\
\text { Cowboy } \\
\text { None } \\
\overline{-} \\
\text { None } \\
\text { None } \\
\text { Farm Labor } \\
\text { None } \\
\text { Prospector } \\
\text { Prospector } \\
\text { None } \\
\text { Cowboy } \\
\text { None } \\
\text { None }\end{array}$ & $\begin{array}{l}N, N,- \\
N, N,- \\
\because \because,- \\
\because \because- \\
\because \because,- \\
Y, Y,- \\
N, N,- \\
\because \because- \\
\because,- \\
N, N, N \\
N, N,- \\
N, N,- \\
N, N,- \\
N, N,- \\
N, N,- \\
N, N,- \\
\because,-- \\
N, N,- \\
N, N,- \\
N, N,-\end{array}$ & 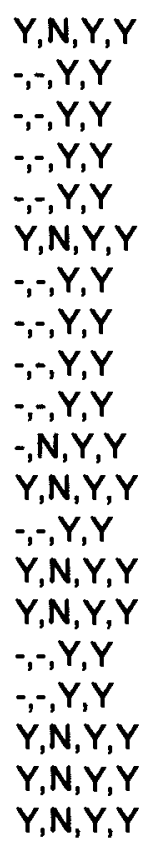 & $\begin{array}{l}\text { S,S,S } \\
\text { S,S,S } \\
\text { S,S,S } \\
\text { S,S,S } \\
\text { S,S,S } \\
\text { S,S,S } \\
\text { S,S,S } \\
\text { S,S,S } \\
\text { S,S,S } \\
\text { S,S,S } \\
\text { S,S,S } \\
\text { S,S,S } \\
\text { S,S,S } \\
\text { S,S,S } \\
\text { S,S,S } \\
\text { S,S,S } \\
\text { S,S,S } \\
\text { S,S,S } \\
\text { S,S,S } \\
\text { S,S,S }\end{array}$ \\
\hline
\end{tabular}


Table 5. 1910 Census Data on Native American People in Southern Nye Countya (Page 3 of 4)

\begin{tabular}{|c|c|c|c|c|c|c|c|}
\hline Name, Rel. to $\mathrm{HOH}$ & G A & $\begin{array}{l}\text { Mar } \\
\text { CY }\end{array}$ & $\begin{array}{l}\text { Child } \\
\text { D N }\end{array}$ & Occupation & $\begin{array}{l}\text { Language } \\
\text { RWS }\end{array}$ & $\begin{array}{l}\text { Economic } \\
\mathrm{H} \times \mathrm{AT}\end{array}$ & $\begin{array}{l}\text { Ethnic } \\
\text { E F M }\end{array}$ \\
\hline $\begin{array}{l}\text { Johnnle Bass } \\
\text { Minnie, Wife } \\
\text { BIII Dock } \\
\text {-, Wife } \\
\text { Pahone, Dau } \\
\text { Jane, Mother } \\
\text { Toni, Brother-in- } \\
\text { law } \\
\text {-, Brother-in-law } \\
\text {-, Brother-in-law } \\
\text { Tom Bollnas }\end{array}$ & $\begin{array}{l}M, 24 \\
F, 20 \\
M, 40 \\
F, 33 \\
F, 7 \\
F, 62 \\
M, 15 \\
M, 12 \\
M, 10 \\
M, 21\end{array}$ & $\begin{array}{l}M, 3 \\
M, 3 \\
M, 10 \\
M, 10 \\
S,- \\
W,- \\
\\
S,- \\
S,- \\
S,- \\
S,-\end{array}$ & $\begin{array}{l}-,- \\
-,- \\
\because- \\
1,1 \\
-,- \\
2,1 \\
\\
-,- \\
-,- \\
-,- \\
-,-\end{array}$ & $\begin{array}{l}\text { None } \\
\text { Laundress(?) } \\
? \\
\text { None } \\
\text { None } \\
\square \\
\overline{-} \\
\text { Cowboy }\end{array}$ & $\begin{array}{l}\text { N,N,- } \\
N, N,- \\
N, N,- \\
N, N,- \\
-, N,- \\
N, N,-\end{array}$ & $\begin{array}{l}Y, N, Y, Y \\
-,-, Y, Y \\
Y, N, Y, Y \\
-\because, Y, Y \\
-,-Y, Y, Y \\
\because-Y, Y, Y\end{array}$ & $\begin{array}{l}\text { S,S,S } \\
\text { S,S,S } \\
\text { S,S,S } \\
\text { S,S,S } \\
\text { S,S,S } \\
\text { S,S,S }\end{array}$ \\
\hline
\end{tabular}

Rhyolite Census Precinct

$\begin{array}{lllllll}\text { Doc WIIllam } & \text { M,45 } & \text { M, } & -,- & \text { Woodcutter } & \text { N,N,- } & \text { S,S,S } \\ \text { Tina, Wife } & \text { F,46 } & \text { M, } & 5,5 & \text { None } & \text { N,N,- } & \text { S,S,S } \\ \text { George, Son } & \text { M,20 } & \text { S,- } & -, & \text { Woodcutter } & \text { N,N,- } & \text { S,S,S } \\ \text { Shug, Dau } & \text { F,16 } & \text { S,- } & -,- & \text { None } & \text { N,N,N } & \text { S,S,S } \\ \text { Liza, Dau } & \text { F,? } & \text { S,- } & -, & \text { None } & \text { N,N,- } & \text { S,S,S } \\ \text { Pioni (?), Dau } & \text { F,10 } & \text { S,- } & -,- & \text { None } & \text { N,N,N } & \text { S,S,S } \\ \text { ?, Sister } & \text { F,35 } & \text { S,- } & -,- & \text { None } & \text { N,N,N } & \text { S,S,S } \\ \text {-, Mother } & \text { F,65 } & ?,- & ?, ? & \text { None } & \text { N,N,- } & \text { S,S,S } \\ \text {-, Lodger } & \text { F,60 } & ?, ? & -,- & \text { Basketweaver N,N,- } & \text { S,S,S } \\ \text {-, Lodger } & \text { F,45 } & ?, ? & 2,2 & \text { Basketweaver N,N,- } & \text { S,S,S }\end{array}$

Key to columns, from left to right:

- Rel. to $\mathrm{HOH}=$ Relation to head of household. Heads of household are shown in boldface, with all individuals living in the same household indented under the $\mathrm{HOH}$.

- $G=$ Gender $(M=$ male, $F=$ female $)$

- $A=$ Age

- $C=$ Conjugal status $(M=$ married, $S=$ single $)$

- $Y=$ Years married

- $D=$ Number of children, if a mother

- $\mathbf{N}=$ Number of surviving children, if a mother

- $R=$ Reads English ( $Y=$ yes, $N=$ no)

- $W=$ Writes English ( $Y=$ yes, $N=$ no) 
Table 5. 1910 Census Data on Native American People in Southern Nye County (Page 4 of 4 )

Footnotes (continued)

- $S=$ Speaks English $(Y=$ yes, $N=$ no)

- $H=$ Home $(O=$ owns a home, $R=$ rents a home)

- $X=$ Home is a farm ( $Y=$ yes, $N=$ no)

- $A=$ Dwelling of temporary or aboriginal-style construction $(Y=$ yes, $N=n o)$

- $T$ = Pays taxes

- $E=$ Ethnic group affiliation*

- $F=$ Father's ethnic group affiliation"

- $M=$ Mother's ethnic group affiliation"

- $P=$ Paiute, $S=$ Shoshone, $D=$ Panamint Shoshone, $W=$ White, $P S=$ Mixed Paiute and Shoshone descent, WP = Mixed White and Paiute descent, and WS = Mixed White and Shoshone descent.

Question marks are used to indicate that handwritten census entries are illegible or uncertain. Dashes are used to indicate the item was left blank on the census form.

Data are from 1910 Census Enumeration for Nevada (microfilm) [Bureau of the Census, Department of Commerce, 1913b] 
The Native American population of Springdale precinct was identified as entirely Shoshone, with listed occupations including cowboy (3), farm laborer (2), laundress (1), prospector (2), wood hauler (1), and "none" (10). The rest were children and adolescents.

The Native American population of Johnnie precinct was identified as predominantly Paiute, with 23 Paiutes, 11 Shoshones, 1 Panamint (Shoshone), 8 persons of mixed Paiute/Shoshone parentage, and 2 of mixed Paiute/white parentage. Listed occupations include farmer (18), farm laborer (10), and none (7). The rest were children and adolescents. [Bureau of the Census, 1913b]

1910 Native Americans: Indian Springs: - "Whispering Ben," identified as an "Indian chief," sold Indian Springs ranch to Charles Towner in 1876. It was sold again in 1903 to the Clark Railroad interests. In 1910, Mr. and Mrs. Ira MacFarland bought the ranch. They sold it in the 1920s "with the proviso that the couple had lifetenancy in the ranch house...Mrs. MacFarland maintained residence there until her death in 1957." "Whispering Ben worked for the MacFarlands and had his camp on the ranch." [NTS News, vol. 9, no. 16, August 5, 1966, pp. 4-7]

1910 Native Americans: Ash Meadows: farming - A newspaper article indicated that "Indian farmers" at Ash Meadows are sending "dandy" melons to Rhyolite. [Oh You Watermelon!," Rhyolite Herald, vol. 6, no. 17, August 20, 1910, p. 1, col. 6]

1910 Shoshones: Ash Meadows: Black family - Jack Longstreet shot and killed Bob Black, identified as a Shoshone man. "Late Saturday evening an inquest was held on the body of Bob Black, the Shoshone Indian, who on Friday was shot by Jack Longstreet...It is also stated that the Indian is the one who killed a number of his own tribe down on the Amargosa some years ago, but for this he was never apprehended." ["Longstreet Killed Indian in Self-Defense," Carson City News, vol. 9, no. 205, August 31,1910, p. 1, col. 1]

1910 Telluride: mining activities - Construction of mineshafts, etc., was in progress around Telluride. [Rhyolite Herald, vol. 5, no. 51, April 16, 1910, p. 1, col. 3]

1910 Shoshones: Paiutes: Tonopah: settlement - "A Shoshone Indian woman named Mary was beaten up by two Paiute bucks, all having been under the influence of liquor...The affray happened at a wickiup at the upper end of Florence avenue. That is a Shoshone camp, while the Paiutes live at the north side of Mount Brougher." [Tonopah Sun, vol. 6, no. 18, January 21, 1910, p. 1, col. 4]

1910 Paiutes: Shoshones: Tonopah: liquor: relations between Native Americans and Euroamericans: mobility - An article deplored "the liquor traffic among the festive Shoshones and Paiutes....Before the recent shooting of William Baker at Spanish Springs by Tang Darrow, it was quite a common thing to see Indians going over the stage road from Tonopah toward Manhattan displaying liquor in bottles as well as affording evidence in their own persons... This liquor presumably was bought in Tonopah. And it was about as common to see Indians in the same condition on the road from Manhattan bound this way, with a cargo aboard that it is supposed was taken on at the latter place. This presumes that the red men have a pretty regular source of supply at both points....Since the shooting of Baker most of the 
Indians that formerly floated about this part of the county have hiked over to the Smoky valley. But before this some of the red men, more or less saturated with booze, terrorized women and children at houses out in the country. Several complaints of this were made to the various officers of the county." ["Booze to Indians Causes Trouble," Tonopah Sun, vol. 6, no. 101, April 20, 1910, p. 1, col. 1]

1910 Johnnie district: mining activities - The Johnnie district, on the northwest flank of the Spring Mountains, had its major production between 1910 and 1913. [Cornwall, 1972:38]

1910 Johnnie district: mining activities - The period of greatest activity at the Johnnie mine was 1910-13 with over $\$ 1$ million of production. [Kral, 1951:86]

\section{1-14}

1911 Native Americans: Pahrump: settlement: murder - A coroner's jury found that Charles Tecopa was murdered by Joe Lake, another Native American. Witnesses included several other Native Americans from Pahrump, including individuals identified as "Willie," "Syring," and "Minnie," each of whom signed the transcript with an $x$. [Inquest Report, Nye County Recorder's Office, dated June 8, 1911]

1911 Bare Mountain: mining activities - Marble mining on the north side of Bare Mountain was in the early stages. [Rhyolite Herald, vol. 6, no. 5, May 27, 1911]

1911 Telluride: mining activities - Many men were working 18 miles south of Battle Mountain in the Telluride area. Nearby was the Kimberly district. [Rhyolite Herald, vol. 6, no. 7, June 10, 1911]

1911 Bare Mountain: water resources - Water pipes led from Gold Center to Bare Mountain (a distance of eight miles). [Lingenfelter, 1986:404]

1912 Native Americans: Bullfrog district: wood camp: wood cutters: Indian Kennedy 'Indian Joe Kennedy' was charged with shooting at Isidore Artche at a wood camp at Petergold on the Las Vegas and Tonopah Railroad. Kennedy and several other Indians were drinking near Artche's cabin. Artche accused them of stealing from his cabin, and a shooting incident ensued. [Rhyolite Herald, vol. 7, no. 37, January 13, 1912, p. 1, col. 4]

1912 Native American: Fortymile Canyon: Native American prospecting - In 1912, "one of the Indians who found the Shoshone [mine]" took some high grade ore to a broker in Goldfield and then left without divulging where the ore came from. He was trailed as far as Oak Spring and disappeared into Fortymile Canyon. A party led by Lige Harris then made several attempts to locate an ore ledge in Fortymile Canyon. [Carrara Obelisk, vol. 2, no. 1, May 8, 1914, inside p., col. 3]

1912 Southern Nevada: livestock - The Kawich cattle association aimed to stock the range 100 miles east of Goldfield with 10,000 cattle. [Rhyolite Herald, vol. 7, no. 43, March 23, 1912, inside p., col. 6)

1912 Southern Nevada: livestock - Sheep were ravaging the ranges in White Pine County and northern Nye County. [Rhyolite Herald, vol. 7, no. 41, March 9, 1912, inside p., col. 1]

1912 Amargosa Valley: ranching - Wealthy Chicago meat packers and lumbermen acquired 40,000 acres along the Amargosa above Rhyolite. [Rhyolite Herald, vol. 7, no. 44, March 30, 1912, inside p., col. 1] 
1912 Telluride: mining activities - A mercury furnace was established in 1912, yielding a small production of mercury between 1912-16. [Lincoln, 1923:167]

1912 Owens Valley: Indian reservations - Tracts of land were assigned for reservations at Bishop, Lone Pine, and Big Pine. [Liljeblad and Fowler, 1986:430]

1913 Fluorine district: mining activities - Gold was discovered at the Ace mine, ten miles southeast of Beatty. [Kral, 1951:63-64]

1913 Bare Mountain: mining activities - A new town called Carrara was established along the Las Vegas and Tonopah Railroad, but it never attracted many people. [Lingenfelter, 1986:405]

1913 Bare Mountain: mining activities - Marble mining began. [Lingenfelter, 1986:405]

1913 Telluride: mining activities - The Bull Moose mine produced gold ore from 191315. [Lincoin, 1923:167]

1914 Native Americans: Fortymile Canyon: Native American prospecting - A party was on its way to search for an ore ledge. The ledge was reputed to have been found by one of the survivors of the Jayhawker party. It was thought to have been the source of some rich ore sold by a Shoshone, who was trailed into Fortymile Canyon in 1912. [Carrara Obelisk, vol. 2, no. 1, May 8, 1914, p. 6, col. 3]

1915-19

1915 Native Americans: Oasis Valley area: liquor - A newspaper editor complained about illegal sale of liquor to "Indians around the district." [Carrara Obelisk, vol. 2, no. 24, April 17, 1915, p. 8, col. 2]

1915 Native Americans: Oasis Valley area: camps: liquor - A newspaper editor noted that "[t]here are several of the red skinned persuasion about the district and a good many of these seem to have no difficulty in getting intoxicating liquors from some source. If this is allowed to continue unchecked, it must inevitably result in some criminal act endangering those living in proximity to the Indian camps." [Carrara Obelisk, vol. 3, no. 4, November 27, 1915, p. 8, col. 1]

1915 Native Americans: Oasis Valley area: liquor - A newspaper editor commended Sheriff Norris for convicting individuals who sold intoxicating liquor to local Indian people. [Carrara Obelisk, vol. 3, no. 6, December 4, 1915, p. 8, col. 1]

1916 Native Americans: Pahrump: village - A map titled "Pahrump Valley Ranch - 1916 and 1917 Layout from Pictures and as George Telford Remembers from 8 or 9 years of age by Dorothy Telford 1978" shows an "Indian Village" next to the stream/pond, about three fourths of a mile northeast of the Telford residence and the Hotel. [Lynch, 1978:89]

1916 Bare Mountain: mining activities - A marble quarry was excavated down to 100 feet (15 floors), but only a few loads were ever sold, as the quality was poor. [Lingenfelter, 1986:406]

1917 Shoshones: Ash Meadows: water rights: Ash Meadows Charley - Ash Meadows Charley's rights to spring water for irrigation were contested by white neighbors. Charley testified to State Engineer J.G. Scrugham that he lived at the springs and that he had accepted money from G.G. Davis some ten years before in exchange for allowing Davis to use some of the water for one year only. Testimony taken in Ash Meadows, September 29, 1917, in Correspondence Files of Lorenzo Creel, Lorenzo Creel Collection, UNR] 
1917 Cherokee: Ash Meadows: land claims and water claims: William G. Morris William Gideon Morris, a Cherokee, settled in Ash Meadows in about 1907. In 1915, he settled on a parcel of land the water rights of which later came into dispute. Conflicting claims between Morris and a Mrs. Etta E. Garner were heard by a U.S. Commissioner in 1917 in Beatty, and Mr. Morris' claim to the land was upheld. The conflict continued over rights to the water of "Big Spring." Morris appealed to Indian Agent Lorenzo Creel for assistance in the dispute. After H.K. Palmer, Engineer, surveyed the land, the State Engineer and Indian Agent L.A. Dorrington assisted Morris in filing a claim for water rights. Dorrington urged him that once notified his application had been granted, he should do his "best to reclaim your land and your constant use of this water". [Letter to L.D. Creel from William Morris dated December 28, 1917; Letter to L.D. Creel from William Morris dated February 24, 1918; Letter to William Morris from L.A. Dorrington; Application for Permit to Appropriate the Public Waters of the State of Nevada by William Gideon Morris, and also signed by L.D. Creel and L.A. Dorrington, undated. Lorenzo Creel Collection, Special Collections, UNR]

1917 Shoshone: Ash Meadows: water rights: Ash Meadows Charley - Ash Meadows Charley's rights to water were contested by Euroamerican neighbors. [Letter from Lorenzo Creel dated January 3, 1918, Lorenzo Creel Collection, UNR]

1917 Ash Meadows: mining activities - An enormous clay bed was discovered. [Lingenfelter, 1986:409]

1918 Native Americans: Ash Meadows: water rights - Indian Agent L.A. Dorrington noted that "there are two factions of the whites in that section [Ash Meadows] who are fighting each other over land and water matters, and so far as I know the Indians have had no one to look after their interests." [Letter dated February 16, 1918, Lorenzo Creel Collection, Special Collections, UNR]

1918 Native Americans: Ash Meadows: water rights: Ash Meadows Charley - William Morris noted that the water rights of Ash Meadows Charley and Ash Meadow James were being challenged by Euroamericans and that H.K. Palmer, Engineer was on his way to survey their land, after having surveyed that of Morris. [Letter from William Morris dated February 24, 1918, Lorenzo Creel Collection, UNR]

1918 Native Americans: Ash Meadows: agriculture: water rights - Indian Agent Lorenzo D. Creel noted that "[w]e have a number of Indians residing in that locality [Ash Meadows] who have been doing some gardening and farming and using the water of certain spring for an indeterminate number of years." [Letter to Marguerite David from L.A. Dorrington and L.D. Creel dated March 4, 1918, Lorenzo Creel Collection, UNR]

1918 Ash Meadows: mining activities - The Ash Meadows district began producing commercial clay in 1918 and continued production through at least 1950. [Kral, 1951:13-15]

1918 Bare Mountain: mining activities - Mining of fluorspar on Bare Mountain began in 1918 and continued through the 1970s. [Cornwall, 1972:35]

1918 Bare Mountain: Fluorine district: mining activities - Large amounts of fluorspar were mined on Bare Mountain, beginning in 1918. [Pippin and Zerga, 1983:58-9] 
1918 Fluorine district: mining activities - Fluoride ore was discovered in 1918. [Kral, 1957:60]

1918 Fluorine district: mining activities - Fluorspar was produced from Bare Mountain from 1918 through 1951. The Crowell Fluorspar mine was located five miles east of Beatty and the Vidano group was located another mile to the east. [Kral, $1951: 60]$

1919 Telluride: mining activities - Fluoride production began at Telluride. [Lincoln, 1923:167]

1920-24

1920 Nye County: population - According to the 1920 census, Nevada had a total population of 77,407 and Nye County had a total population of 6,504. The population of Nye County precincts in the vicinity of the study area were as follows:

a. Ash Meadows precinct, 63.

b. Beatty precinct, 115.

c. Carrara precinct, 54.

d. Pahrump precinct (Johnnie), 94.

e. Pioneer precinct, 44.

f. Rhyolite precinct, 14.

[Bureau of the Census, 1921:520. Detailed census rolls for 1920, giving names, occupations, tribal affiliation of Native American people, and other specific data are sealed until 1992. Detailed census rolls for 1930 are sealed until 2002, those for 1940 are sealed until 2012, and so on.]

1920 Shoshones: Paiutes: Ash Meadows: water rights: Mary Scott: Cherokee - William Gideon Morris, a Cherokee farmer in Ash Meadows, wrote to Indian Agent L.A. Dorrington concerning three orphaned Paiute children in the care of Mary Scott and Shoofly James, both Shoshones living at Ash Meadows, as their guardians. The children's grandfather left them a home with three small springs used by him for irrigation since 1904. Morris noted that the springs were "all on Government Land and have never been used by any other person or persons than Indians." Morris also noted that William Ishmael and George Ishmael, recent arrivals to Ash Meadows, had indicated to other whites that they intended to file claims to those springs. Indian Agent Dorrington advised Morris that no other filings had so far been claimed on the land or water in question and indicated he would assist in securing claims for the Indians. Morris also expressed concern about the Ishmaels infecting the "Indian Camp" with syphilis. [Letter to Indian Agent L.A. Dorrington from William Morris dated November 9, 1920, Letter to William Morris from Indian Agent Dorrington dated November 24, 1920, Lorenzo Creel Collection, UNR]

1920 Native Americans: Ash Meadows: water rights - "According to the report of Mr. Palmer there are other Indians in that neighborhood [Ash Meadows] for which a water filing should be made." [Letter to L.A. Dorrington from L. D. Creel, Lorenzo Creel Collection, UNR]

1922 Native Americans: land titles: southern Nye County - A newspaper article stated that Lorenzo D. Creel, a special supervisor of the U.S. Indian Service, was taking a census of the Native American population of Nevada and California, including 
"outlying sections" of Nye County, which included Ash Meadows. After Nye County, he was to carry out a similar effort in Inyo County. A major part of Creel's mission was reportedly to assist Native Americans in perfecting the titles to their homesteads. [Tonopah Mining Reporter, vol. 2, no. 12, November 18, 1922, p. 1, col. 3]

1922 Oasis Valley: mining activities - There was a new wave of activity in the vicinity of Beatty, Springdale, and Pioneer, with renewed prospecting for minerals, extensive drilling for water wells, and an expansion of agriculture. [Tonopah Mining Reporter, vol. 1, no. 22, May 27, 1922, p. 1, col. 7$]$

1922 Native Americans: Tonopah: Fourth of July - The program for Tonopah's Fourth of July celebration included special activities for children and special activities for Native American children. "There will be special games and races for Indian children." ["July Fourth Entertainment is Completed," Tonopah Mining Reporter, June 24, 1922, inside p., col. 3]

1923 Native Americans: Oasis Valley: Fourth of July: sports - The program for Beatty's Fourth of July celebration, held at Lockett's ranch, included "a race solely for the indian maids on their ponies." [Tonopah Mining Reporter, vol. 1, no. 44, July 1, 1923 , p. 2, col. 7]

1923 Beatty area: Homestead Act $-22,000$ acres of land near Carrara were opened to homesteading by Wortd War I veterans, part of a 110,000-acre total, the balance of which was located in San Bernardino and San Diego Counties in California. [Tonopah Mining Reporter, vol. 2, no. 45, July 7, 1923, p. 1, col. 2]

1923 Beatty area: mining activity - "Considerable mining activity is under way in and around Beatty, where gold, silver, cinnabar, silica, and flurospar deposits are being developed. The marble deposits at Carrara are being developed further and a high grade lead-silver mine is also being developed not far from the marble. At Pioneer, the Mayflower company's holdings are being developed..." [Tonopah Mining Reporter, vol. 3, no. 14, December 1, 1923, p. 1, col. 6]

1924 Native Americans: Beatty: drunkenness, assault: Mike Hughes: Shaw family Mike Hughes, a Native American, shot his brother-in-law, Ika Shaw, after a night of drinking. Hughes was arrested and taken to jail in Tonopah. Shaw was placed in the county hospital. A warrant was issued for the arrest of Hank Shephard of Beatty for selling liquor to Native Americans. The article reported that "[t]here has been considerable trouble among the Indians of the southern section of this county lately caused by drunken brawls." [Tonopah Mining Reporter, vol. 3, no. 37, May 10, 1924, p. 4, col. 6]

1924 Native Americans: Beatty: assault: court case: Mike Hughes: Shaw family - Mike Hughes, who reportedly shot Ika Shaw during a drunken brawl, had a preliminary hearing before Judge Cuddy in Tonopah. Hughes pleaded guilty to the charge of assault and was bound over to the district court. [Tonopah Mining Reporter, vol. 3, no. 38, May 17, 1924, p. 2, col. 5]

1924 Shoshones: Beatty: assault: court case: Mike Hughes: Shaw family - Mike Hughes, a Shoshone man, shot his brother-in-law lke Shaw. After a night of drinking, Hughes saw someone approaching, feared he was about to be assaulted, and shot without knowing who the person was. The two lived in neighboring houses in Beatty. [Court records in the case of the State of Nevada vs. Mike Hughes, May 1924] 
1924 Johnnie district: mining activities - The Congress mines were expected to reopen. [Tonopah Mining Reporter, vol. 4, no. 3, September 20, 1924, p. 2, col. 4]

\section{5-29}

1925 Native Americans: Ash Meadows: Oasis Valley: construction labor - Construction of Scotty's Castle began in 1925 and continued through 1931. Many Native Americans were employed on the project. "When reviewing the detailed payroll records, one notes that the most consistent and steady laborers were those indians from Grapevine Canyon, Lida, Fish Lake Valley, and Beatty who were members of three or four extended families for which Grapevine Canyon was a part of their traditional home ranges. Indians from central Nevada, eastern California, and Ash Meadows worked for short and irregular stretches." [Sennett-Walker, 1987:83]

1926 Beatty area: mining activities - The economy of Beatty was on an upswing due to "nearly boom conditions" in lead mining at Leadfield, west of Beatty. The Pioneer mine was operating, and a party of California investors came to Beatty on a special Pullman on the Tonopah and Tidewater Railroad. [Tonopah Mining Reporter, vol. 4, no. 40, January 9, 1926, inside p., col. 4]

1926 Shoshones: fandango - The annual Shoshone fandango began at "Milletts" and was to last five nights. "All the Indians for hundreds of miles around will be there; that is, all the Shoshones. Others will be barred, [Chief Snow in the Mountains] explained." There was to be horse racing, bronco-busting, gambling, and dances. [Tonopah Mining Reporter, vol. 4, no. 46, August 28, 1926, p. 2, col. 4]

1927 Native Americans: Bishop Agency: census - A 1927 census of Bishop Agency Native Americans traced the Hungry Bill family and identified them as Shoshone. Several family members were living in the Death Valley area at the time of the census. [Greene, 1981:366-368]

1928 Paiutes: Ash Meadows: Black family - After the death of Jack Longstreet, his common-law wife Fannie Longstreet returned to Ash Meadows, her birthplace. She "soon found that she had more kin than she had counted on. At first, coming back as a respected widow to the tribe that had once cast out her renegade brother may have seemed a balm, to family pride...Fannie, with her monthly allotment [from Longstreet's estate] was wealthy by the standards of Ash Meadows, so wealthy that Henderson [administrator of the estate] began receiving letters from Indians all around the country who claimed an interest in the Longstreet estate....As Henderson phrased it, 'The Indians all moved in and thought she had a million dollars.' After a few months of this, Fannie fled north." [Zanjani, 1988:146-147]

1928 Native Americans: Ash Meadows: Black family: intermarriage of Native Americans and Euroamericans - Jack Longstreet's obituary stated that a Native American woman [Fannie Black] had been his wife for 35 years, that he met her at Ash Meadows, and that "Fanny...still has relatives in that section." ["Jack Longstreet, Real Pioneer, Dies at Hospital in Tonopah," Tonopah Mining Reporter, vol. 6, no. 46, July 28, 1928, p. 4, col. 6]

1928 Native Americans: Whiterock Spring area: Captain Jack - Captain Jack was reported to have died in 1928 at his rock shelter some three miles to the north of Whiterock Spring. ["Archaeologist and Party in Survey of 40-Mile Country," Goldfield News and Beatty Bulletin, vol. 44, no. 50, April 23, 1948, p. 2, col. 4] 
1928 Wahmonie district: mining activities - The Wahmonie mining camp (four miles northwest of Cane Spring) mushroomed and then waned during three months in 1928. [Koenig, 1984:66]

1928 Wahmonie: mining camp - High grade silver-gold ore was discovered in February 1928 at Wahmonie on the east edge of Jackass Flat. By March, there was a population of 500 . By April, there was a post office and roughly 1,000 people in the camp. By the end of the year, the town was nearly deserted. [Paher, 1970:32]

1928 Wahmonie district: mining activities - The Wahmonie district was rediscovered in the late 1920s with a strike of high-grade gold and silver ore in 1928. Within three weeks, the camp had a population of over 2,000. [Kral, 1951:206]

1928 Wahmonie district: mining activities: water resources - Cane Spring was the main water supply for the mining camp of Wahmonie. [Koenig, 1984:90]

1928 Wahmonie district: mining activities - 1,351 mining claims were staked in less than a month. [Anonymous, 1928:862]

1928 Wahmonie district: mining activities - The Wahmonie Mines Company reactivated the Hornsilver mine, sinking a 500-foot shaft. [Kral, 1951:63-64]

1928 Wahmonie district: mining - The Wahmonie district produced a small amount of gold and silver. [Cornwall, 1972:41]

1928 Fluorine district: mining activities - Fluorine was an active camp from 1928-29. Between 1932 and 1936, there was a 50-ton mill. [Kral, 1951:63-64]

1928 Whiterock Spring: mining activities: Captain Jack - Some 60 claims were located in the Whiterock Spring country "at the scene of the strike made by Ray H. 'Big Ray' Morris who began a systematic prospect of the country last November, some 40 miles due east of Beatty. The 'Captain Jack' mine is one of Nevada's so-called 'mythical' properties which received its name when Captain Jack, an Indian, frequently showed up in south Nevada with pieces of rich gold-bearing rock which he turned into cash. The Indian took to his grave the secret of where he found it, the legend goes." ["Capt. Jack Mine is Believed Found," Caliente Herald, vol. 2, no. 4, January 31,1929, p. 1, col. 6]

1929 Fluorine district: mining activities - The Grand Junction mine, four miles northeast of Carrara, had shafts, etc., under construction in 1929. [Kral, 1951:63-64]

1920- Shoshones: Ash Meadows: Pahrump: Albert Howell: Mary Scott - Steward

30 s identified Ash Meadows as a Southern Paiute area. He said the Ash Meadows Southern Paiutes "occupied also Pahrump, Nevada....the people of this locality claimed political and social independence of Las Vegas. Today and probably formerly many Shoshoni are intermixed with the Paiute." In the mid-1930s, Steward conducted ethnographic interviews with three Native American residents of Ash Meadows: "AH" (apparently Albert Howell), identified as a "half-Negro, halfSouthern Paiute man;" "MHo," identified as a "full-blood Southern Paiute woman" married to $\mathrm{AH}$ (the couple moved from Pahrump to Ash Meadows at the time of their marriage); and "MS," identified as "three quarters Southern Paiute, onequarter Shoshoni," born about 1865 in Ash Meadows and still living there in the 1930s. [Steward, 1941:212-214] 
1920- Shoshones: Oasis Valley: territory - Steward identified Beatty as a Shoshone

30 s area and said "[t]his group ranged from the Grapevine Mountains, bordering Death Valley on the east, to the Belted Mountains to the northeast. Contacts with Death Valley, Lida, and Kawich region Shoshoni; also, somewhat with Southern Paiute of Ash Meadows." Steward identified his interviewee "TSt" as a "full-blood Shoshoni man, bom ca. 1865 near Beatty, at or near which he has subsequently lived..." [Steward, 1941:212,214]

1920- Shoshones: Lida - Steward identified Lida as a Shoshone location, "one of

30s many independent villages scattered in the deserts north of Death Valley. It included a few Northern Paiute in its population. Contacts with Fish Lake Valley Paiute and Death Valley and Beatty Shoshoni. Informant: JS." [Steward, 1941:212]

\section{0-34}

1930 Nye County: population - According to the 1930 census, Nevada had a total population of 91,058 . Nye County had a total population of 3,989 and an Indian population of 366 . The population totals for precincts in the vicinity of the study area were as follows:

a. Ash Meadows precinct, 140.

b. Beatty precinct, 239.

c. Pahrump precinct, 39.

d. Pioneer precinct, 42.

e. Wahmonie precinct, 6 .

[Bureau of the Census, 1932:149; Bureau of the Census, 1943:753]

1930 Mellan Mountain: mining activities - There were new discoveries and limited production in 1930 at Mellan Mountain, 38 miles east of Goldfield. [Kral, 1951:131]

1931 Native Americans: Ash Meadows: intermarriage of Native Americans and Euroamericans: Black family - The death certificate of Fannie Longstreet, widow of Jack Longstreet, identified her as an Indian born in Ash Meadows. She was the daughter of Bob Black and 65 years old at her death (thus born around 1866). [Death Certificate, Inquest File, Nye County Courthouse, dated May 13, 1931]

1932 Native Americans: Beatty: school - A picture of the 1932-1933 Beatty junior high school class shows eleven students, at least three of them of Native American ancestry. [Photograph, File 309, Central Nevada Historical Society]

1932 Native Americans: Beatty area: cattle rustling: trackers: Mike Hughes - Mike Hughes, a Shoshone, was accused of assisting Fred $E$. Lea in illegally branding cattle belonging to Samuel S. Lockett in the Black Mountain area. Mike Hughes fled and did not appear in court. Sheriff Thomas and two white men were accompanied by two Native American trackers in an attempt to locate the horses and the places the accused men had camped. The State of Nevada vs. Fred E. Lea and Mike Hughes, April 29, 1932; the State of Nevada vs. Frederick E. Lea, December 11, 1933, Nye County Recorder's Office]

1933 Paiutes: southern Nevada: political leadership: mobility - "With a mournful chant pouring from 300 aboriginal throats...the Southern Nevada Piute tribe, including Indians of Southern Utah, Southern Nevada and Northwestern Arizona, installed a new chief recently. Their old chief, Jack Penance...was killed recently in a very 20th century automobile, loaded with blankets, his squaw and about eight children 
blew a tire, overturned...One of his friends, known to white men as Baboon, served as head of the Nevada Indians a short time until a pow-wow could be set and distant Piutes called into meeting. Over desert roads they came, many by foot, horseback and wagon, but the number who maneuvered themselves and families to the reservation in rattling, brass-bound flivvers was amazing to old time desert dwellers.... Harry Skinner, young govemment Reeducated Piute from Arizona, was named chief...The southern Piutes have little in common with the northern Pahutes, whose headquarters are near Indio, Cal. The Piutes are considered more industrious than their indolent cousins, the Pahutes." ["Piutes Install New Chieftain at Tribe Ceremonial," Tonopah Daily Times-Bonanza, October 4, 1933, p. 4, col. 1]

1933 Spring Mountains: forestry camp - The Civilian Conservation Corps operated a forestation camp with about 200 men in the Charleston Mountains in 1933. ["Boys Say Camp Life Picking Up at Charleston," Tonopah Daily Times-Bonanza, vol. 18, no. 183, June 16, 1933, p. 1, col. 3]

1930s Shoshones: Death Valley: village - As of the 1930s, 17 Native Americans reportedly were living at Hungry Bill's ranch during the summertime. [Greene, 1981:368]

1930s Owens Valley: water resources: Indian reservations - In the early 1930s, the City of Los Angeles proposed a variety of plans for consolidating or removing Indian people remaining in Owens Valley as part of its project for securing all the water resources of the Owens Valley. A series of land exchanges involving the Bishop, Lone Pine, and Big Pine reservations was approved by Congress, and by a majority of Indian people involved. [Liljeblad and Fowler, 1986:431]

1930s Bulfrog district: mining activities - Major mines in the Bullfrog district after 1911 were the Coen Companies with over $\$ 1,000,000$ gross yieid from 1929 to 1939; the Polaris mine, with $\$ 35,000$ production from 1934-37; and the Crowell, with $\$ 39,000$ production from 1934-40. [Couch and Carpenter, 1943:118]

1930s Bulfrog district: mining activities - The original Bullfrog mine, later called the Burn Ball mine, had considerable work done in early 30s. [Kral, 1951:35]

\section{5-39}

1936 Native Americans: Beatty: village: Native American students - Ert Moore, who taught in Beatty from 1936 to 1942, reported that at the beginning of the 1936-37 school year there were about 25 Native American children and about 15 Euroamerican children in the elementary grades, while in the high school grades there were 8 Native Americans and 2 Euroamericans. "The Indian children came from the Shoshone indian camp across the Amargosa River from the town. They lived in all types of shacks and brush shelters...The camp had an Indian medicine man to whom they first turned for medical and spiritual help. He used herbs and secret pow-wows...I found the Indian children very, very slow to learn, and eventually found that they were not thinking in English but they were thinking in Indian. All school work had to be translated over into the Indian language and thought through and then tumed back into English. Even the really bright ones were doing this." [Moore, 1979:20-21]

1936 Native Americans: Beatty: Native American camp: pinyon nuts: pow-wows - Ert Moore, who taught in Beatty from 1936 to 1942 noted that "[o]ne day in early October of my first year there, not an Indian child appeared at school. This was puzzling and astounding and we waited for noon to see if they came for their 
lunch. None showed up...I went to the Indian camp and found it completely deserted. I knew they held pow-wows and assumed they had gone to Ash Meadows Nevada, for one of these. But on the second day when they had not returned I called the Indian Service....I was informed that the Indian children and parents were gathering pine nuts near Lida in the Fish Lake Valley of Nevada." [Moore, 1979:25]

1936 Native Americans: Beatty: Pahrump: employment - A 1937 BIA report listed the following Native American individuals as having been employed on WPA projects during 1936:

\author{
Holley W. Charley of Beatty \\ Wilbur Patterson of Beatty \\ John Scott of Beatty \\ Louie Sharp of Beatty \\ Ike Shaw of Beatty
}

\author{
Sullivan Shaw of Beatty \\ Tom Stewart of Beatty \\ Jud Stewart of Beatty \\ Jim Long of Johnnie \\ Jim Steve of Pahrump
}

[TC-BIA, 1937a:21]

1937 Native Americans: southern Nye County: population - A 1937 survey produced jointly by the BIA and the Soil Conservation Service provided the following population figures for Native American people in what it referred to as the "BeattyPahrump Area," encompassing Beatty, Ash Meadows, Pahrump, and outlying areas:
a. Approximate total of 110 Native American individuals.
b. Approximate total of 30 Native American families.
c. Approximate total of 15 Native American families in the Beatty area.
d. Total of 4 families at Lockhart Ranch two miles northwest of Beatty.
e. Total of 4 Native American families in Ash Meadows.
f. Total of 5 Native American families in Pahrump Valley.
g. Additional families in outlying areas: "The few single families scattered at far outlying points have not been reached."

[TC-BIA, 1937b:4,7,17,21]

1937 Native Americans: Beatty area: population: settlement - The 1937 BIA survey indicated that there were about fifteen Native American families living at Beatty, and another four families living at the Lockhart Ranch two miles northwest of Beatty. Fourteen of the Beatty families were interviewed. Those 14 families included 55 Native American individuals, 29 of them males and 26 of them females. (Extrapolating the average of four persons per family to the additional families not surveyed at Beatty and at Lockhart Ranch would give a total of approximately 75 Native American people in the Oasis Valley area in 1937.) The total population of Beatty was approximately 250 . The report states that "The Beatty camp is a scattering of shacks located at the northeast edge of the town...on railroad property...The camp is mostly used as a winter residence, although it is a permanent location for many of the Indians. During the summer months, part of the employable Indians move their families to the ranches where work is obtained....Four families are squatting on the site known as the old Lockhart Ranch, two miles northwest of Beatty." [TCBIA, 1937b:4,7] 
1937 Native Americans: Beatty area: construction labor: ranch work - The 1937 BIA survey stated that "[d]emand for Indian labor on ranches in this particular area has been displaced to a large extent in the past ten years by the necessity to import labor other than Indians during the time Indians were employed at good wages to build Death Valley Scotty's Castle. Not only did the Indian lose out in opportunities for labor, but in many cases it is reported he was dispossessed of squatting rights on the ranches where he, hitherto, had lived and worked....Some of these Indians have found summer employment at nearby WPA projects, and occasional jobs are found in and around Beatty. Efforts are made at gardening on the railroad-owned land...Most of the male population at Beatty and Lockhart have worked on ranches and show aptitude for agriculture and livestock.... With one exception, little or no interest has been shown in the mining opportunities which are sometimes available." Of the aggregate income of the 14 families studied, WPA employment comprised the largest portion (37.8\%). "Private wages amounted to $21.5 \%$ of the total reported cash income; whereas income from relief and emergency sources was 75.3\%. [TC-BIA, 1937b:2,4]

1937 Native Americans: Beatty: traditional crafts: pinyon nuts: commerce - The BIA survey stated that "[s]ome of the Indian women do excellent basket work, which gives a small additional income...Merchants of the town encourage Indian women to continue basketry work, as this group produces excellent handicrafts which sell at a premium. The merchants also purchase pine nuts when the Indians offer them for sale." Sale of handcrafts was listed as comprising $1.7 \%$ of the 1936 aggregate cash income of the 14 families surveyed in Beatty. [TC-BIA, 1937b:4,6]

1937 Native Americans: Beatty area: ranching - The 14 Native American families surveyed at Beatty owned an aggregate of 30 horses, 10 cows, 26 goats, and 1 plow. $1.2 \%$ of the aggregate cash income of the 14 families studied derived from sale of agricultural products produced by themselves. The significance of subsistence agriculture in the families' own diets was not assessed. [TC-BIA, 1937b:7]

1937 Shoshones: Paiutes: Beatty: Pahrump: intermarriage of Paiutes and Shoshones The 1937 BIA survey stated that "[a]lthough the Shoshones predominate in numbers in this area, there is not the historical background of hard feeling and enmity toward the Paiutes living among them that is so often found elsewhere. The two tribes are intermarried. A few Indians from other tribes are also among them..." Only one interviewee stated that "Beatty Shoshones and Pahrump Paiutes could not work and live together." [TC-BIA, 1937b:3]

1937 Native Americans: Ash Meadows: population: settlement: water rights: agriculture - The 1937 BIA survey indicated that there were four Native American families at Ash Meadows. Two families, comprising eight individuals, were studied. (Extrapolating the average of four persons per family to the other two families would give a total of approximately 16 Native American persons living in Ash Meadows in 1937.) "The location is completely isolated....The group is headed by an aged Indian woman who claims ownership of the land. She had selected the site, built the house, planted a small orchard and garden, and controlled the holdings. Her exact title to the land is not determined. While it is believed to be public domain, a recent controversy over the water was settled by the court in favor of the Indians. About an acre of land is used as garden and orchard, and about 10 acres are irrigated for pasture." [TC-BIA, 1937b:10] 
1937 Native Americans: Ash Meadows: employment: agriculture - "The efforts made at gardening show an aptitude for agriculture on a small scale. Besides ranch or relief work, occasional work is found with one of the nearby mining companies...The cash income was supplemented rather substantially by the food, fruits, and vegetables raised by this group and not tabulated under cash income. Twenty-two percent of this inadequate income was from County Relief and $78 \%$ from private wages." [TC-BIA, 1937b:11,12]

1937 Native Americans: Pahrump: population: settlement: employment - The 1937 BlA survey gave a population of five Native American families living at Pahrump. The four families that were studied comprised 26 persons, 11 of them males and 15 of them females. The average family size was 6.5 persons. (Extrapolating the average family size to the fifth family that was not included in the study would give an approximate total of 32 Native American persons living at Pahrump in 1937.) The community was located on the open desert about one-half mile northwest of the large Pahrump ranch.... on public domain desert land." [TC-BIA, 1937b:17]

1937 Native Americans: Pahrump: employment: agriculture: traditional crafts - "[M]ost of the families leave the camp during the summer months for work on nearby ranches and on ranches near the Nevada-California line." For the four families studied, $23.1 \%$ of their aggregate cash income derived from "Sale of Wild Foods," $1.9 \%$ from sale of handcrafts, and $1.4 \%$ from sale of agricultural produce. $27.2 \%$ of their aggregate cash income was from private wages, $38.9 \%$ from WPA employment, and $7.5 \%$ from County Relief comprising most of the balance. The four families studied owned a total of 27 horses, 3 burros, 2 cows, 2 plows, 2 harrows, 2 wagons, and 1 car. [TC-BIA, 1937b:16-17]

1937 Native Americans: southern Nye County: employment: income - The 1937 BIA study surveyed 20 Native American families from an estimated total of 30 families. Of the 1936 aggregate reported cash income for the 20 surveyed families, $5.2 \%$ of cash income came from the sale of wild foods, $1.6 \%$ from the sale of handcrafts, $1.1 \%$ from the sale of agricultural produce, $27.1 \%$ from private wages, $35.1 \%$ from WPA employment, $15 \%$ from County Relief, $13.1 \%$ from PWA, $1.5 \%$ from ECW, and .3\% from Agency Payrolls. [TC-BIA, 1937b:22]

1937-40 Native Americans: Beatty area: Shaw family: Tom Stewart - In their research for Medicinal Uses of Plants by Indian Tribes of Nevada, Percy Train and his coauthors James R. Heinrichs and W. Andrew Archer interviewed several Native American people in the Beatty area. The three men relied especially upon information given by Ike Shaw and Tom Stewart, both Shoshones. Train, Heinrichs, and Archer credit lke Shaw with a very extensive knowledge of medicinal plants and with a history of effective cures using medicinal plants. The authors noted that "among the Indians such [plant] medicines are quite a source of income. Prices charged were amazing. Five dollars for a small handful of dried leaves or roots was not at all uncommon. Care was sometimes taken to pulverize the material so that the buyers could not recognize the plants and gather them themselves." [Train et al., 1974:1,4]

1937-40 Oak Spring district: mining activities - Exploration for tungsten and molybdenum was conducted in the Oak Spring area. [Cornwall, 1972:38] 
1938 Native Americans: Beatty: school - A photograph of Beatty School students and teachers in the 1938-39 school year shows 49 students, 19 of them visibly of Native American ancestry. [Photo collection of Chloe Calvin Lisle, who taught grades 1-4 that year]

1938 Bullfrog district: mining activities - At the Montgomery mine, the main shaft of the Shoshone was 600 feet deep. Some work was done in 1938, but no production had been recorded since 1911. [Kral, 1951:33]

1939 Bullfrog area: railroads - The last railroad in the Amargosa Valley area (the Tonopah and Tidewater Railroad) discontinued service in 1939. [Kral, 1951:30]

\section{0-49}

1940 Nye County: population - The 1940 census enumerated a total population of 110,247 for the State of Nevada, a population of 3,606 for Nye County, and a total population of 374 Native American people in Nye County. In the 1940 census, the entire county was divided into only four census precincts, with Beatty township encompassing all of Southern Nye County. (The other three precincts were Manhattan township, Round Mountain township, and Tonopah precinct - with roughly twothirds of the county's entire population.) The population total for Beatty township was 359. Of these, a total of 43 persons was given for the category "Other Races," defined as races other than "White" and "Negro," and thus including Indian people. [Bureau of the Census, 1943:753,757]

1940s Bare Mountain: mining activities - Active production of mercury continued at the Telluride and other mines. The Telluride was active until 1943. [Comwall, 1972:36]

1940s Bulfrog area: mining activities - The Senator Stewart mine, east of Rhyolite, was used intermittently by lessees through 1950. [Kral, 1951:34]

1940 Native Americans: Fortymile Canyon: camp: Captain Jack - A photograph by S.M. Wheeler, dated 1940, shows "[w]ickiup ruins below Capt. Jack Cave, Forty Mile Canyon." [Fortymile Canyon File, Photo Collection, Nevada Historical Society]

1947 Shoshones: Beatty: continued residence: Cottonwood family - "Spike" Cottonwood, a Shoshone resident of Beatty, was the lead pitcher for Beatty in a softball match between the Beatty team and the Tonopah team. [Goldfield News and Beatty Bulletin, vol. 44, no. 12, August 1, 1947, p. 1, col. 7]

1947 Paiutes: Shoshones: Pahrump: traditional Native American beliets and ceremonies: Shaw family - Nye County Sheriff W.H. Thomas and Deputy Sheriff Bob Revert, of Beatty, went to Pahrump to investigate a report that "three Indian girls were near death in Pahrump valley as a result of being shot in the stomach with poisoned arrows.... When Revert arrived at the disturbance he leamed that the Shoshones and Piutes had been observing a cry dance to honor the memory of an Indian girl who had been killed a year ago. Part of the ritual involves the burning of certain garments belonging to the deceased. Matters were proceeding very much according to Hoyle up until this point, Revert said, but when a blanket of the departed was tossed onto the fire, Bessie Shaw, a witch doctor, protested and put a hex on the three sisters of the dead girl. This was accomplished by a good deal of long range hocus pocus, atter which the girls were advised that they had been shot in the stomach by invisible poisoned arrows.... The father dispatched a frantic 
call to the Indian equivalent of the Mayo hospital in Arizona. In response to his plea an Indian doctor specialist hustled over to Pahrump where, Revert said, he found him vigorously shaking a string of tin cans, charms and miscellaneous objects to effect a cure...Although the Indians maintained that the girls were quite dead, Revert said that they were walking around in apparent good health..." ["3 Indian Girls Unhurt by Shots from Poison Bow," Goldfield News and Beatty Bulletin, vol. 44, no. 15, August 22, 1947, p. 1, col. 4]

1947 Shoshones: Beatty: sports: Cottonwood tamily: Strozzi family - In a sottball match between the Beatty team and the Goldfield team, the Beatty team included the following men of Native American ancestry: B. Cottonwood, S. Cottonwood, J. Strozzi, and H. Strozzi. [Goldfield News and Beatty Bulletin, vol. 44, no. 17, September 5, 1947, p. 1, col. 5]

1947 Native Americans: Fortymile Canyon: archaeo/ogical exploration: hostilities between Native Americans and Euroamericans - An expedition from Beatty explored the Fortymile Canyon area for evidence of "Indian habitation... The group will be investigating an Indian legend related to Hinton [Jim Hinton, one of the members of the expedition] many years ago by John Shakespeare, blind Piute chief who lived in Lida for many years. He was reputedly over 100 when he died several years ago. Many years ago, runs the legend, the Piutes lived in a lonely, rock area where the white man had never been. All around was native silver, which to the Indians had no value. Children were given pieces of the bright metal to play with, and it was tossed around without concem. One day a party of Spanish horsemen rode into the Piute camp, and when their eyes fell upon the silver they offered to barter with the Indians to obtain some of it. The Piutes, who at the time had never seen a horse, gave freely of the metal in exchange for a few animals. A year or two later the Spaniards retumed when the men were away hunting. They seized all of the silver in sight, and started to ride off with the more desirable squaws when the returning indian hunters arrived suddenly to bar their escape. In the bloody battle that ensued the Spaniards were cut down to a man. But the struggle also cost the Piutes many lives and, in keeping with tribal custom, the dead were placed in caves along with their belongings and the entrance sealed up to keep out the evil spirits. The Piutes then abandoned their camp and departed to make their new home near what is now Lida. Only once did they return, that being many years later, when a small group went back to secure some valuables that had been cached near the old grounds. With them went Shakespeare, who although but a lad at the time, recalled in later years that the party traveled for two days with the sun in our faces. Hinton and his companions have calculated that their destination lay in the $\mathbf{4 0}$ Mile country... They will be searching for caves sealed by human hands..." [Goldfield News and Beatty Bulletin, vol. 44, no. 18, September 12, 1947, p. 1, col. 6-7]

1948 Shoshones: Beatty: Strozzi family - Dolores Strozzi, daughter of Mr. and Mrs. Cesar Strozzi (a Native American/Euroamerican couple) and Marcus Looney were married. [Goldfield News and the Beatty Bulletin, vol. 44, no. 48, April 29, 1948, p. 1, col. 4]

1949 Shoshones: Beatty: Shoshone family - "Danny Shoshone, 18-year-old Beatty Indian youth...slipped away from Nye county authorities in Tonopah a week ago while attached to a work detail near the county jail...serving a 60 day sentence for robbery....Shoshone is believed to have obtained a ride to the general vicinity of 
Beatty where he contacted an uncle with a request that he be conveyed to Fumace Creek... [later he] apparently went deeper into California..." ["Danny Shoshone Flees Custody," Goldfield News and Beatty Bulletin, vol. 47, no. 1, May 13, 1949, p. 1, col. 1]

1949 Shoshones: Beatty: sports - In a Labor Day horseshoe pitching contest involving teams from Beatty, Shoshone, and Tonopah, several Shoshone men from Beatty competed, including Bombo Cottonwood, Spike Cottonwood, Bobby Shoshone, and Joe Strozzi (half-Shoshone). Spike Cottonwood was on the first-place team. [Goldfield News and Beatty Bulletin, vol. 47, no. 18, September 9, 1949, p. 1, col. 6]

\section{Since 1949}

1950 Nye County: population - The 1950 census showed a total population of 160,083 for the State of Nevada, a population of 3,101 for Nye County, and a Native American population of 383 for Nye County. The 1950 census divided Nye County into five precincts: Beatty precinct encompassed the entire southern portion of the county and had a population of 487 according to the census. [Bureau of the Census, 1952:28-5,28-6,28-41]

1950 Shoshones: Beatty: sports: Cottonwood family: Strozzi family - Pitchers for the Beatty softball team included Harry Strozzi (son of Euroamerican/Shoshone couple) and Bombo Cottonwood (a Shoshone). [Goldfield News and Beatty Bulletin, vol. 48 , no. 23, September 8, 1950 , p. 1, col. 1]

1950 Native Americans: Beatty: Shaw family - Bessie Shaw was buried in the Beatty cemetery atter passing away in Schurz. "She and her husband Ike Shaw have lived in the Indian section near Beatty for many years." Bessie Shaw "was regarded by members of her Shoshone tribe as possessing magical powers." [Go/dfield News and Beatty Bulletin, vol. 48, no. 31, November 3, 1950, p. 1, col. 4]

1950 Bullfrog area: mining activities - The Crowell Fluorspar mine in the Fluorine district was active at least through 1951. [Kral, 1951:30]

1953 Shoshones: Beatty: Shoshone family - David Shoshone was riding in a truck with Mrs. John Way and her son Frank when the "wishbone" of the truck fell out. David was cut behind the ear, requiring two stitches. [Goldfield News and Beatty Bulletin, vol. 50 , no. 39 , June 26,1953 , p. 1 , col. 3]

1953 Paiutes: Beatty: law enforcement: Gilbert Landis - Gilbert Landis, a Paiute man born in Big Pine and raised in the Lida area, became a full-time deputy sheriff in 1953 atter four years of part-time service. He initially served under Bob Revert and later took full charge of law enforcement in the Beatty area. He served until retirement in 1968. ["Fellow Officers Honor Gilbert Landis," Tonopah Times Bonanza and Goldfield News, July 5, 1968, p. 4, col. 1]

1959 Shoshone: Beatty: law enforcement: Strozzi family - Joseph Strozzi was swom in as a deputy sheriff for the Beatty area. His mother was a local Native American woman. [Oath of Otfice, Nye County Recorder's Office, January 6, 1959]

1960 Nye County: population - According the 1960 census, Nevada had a total population of 285,278 and a total Native American population of 6,681. Nye County had a total population of 4,374 and a Native American population of 152 . Beatty township had a total population of 1,153. [Department of Commerce, Bureau of the Census, 1961:30-5,30-8,30-41] 
1961 Shoshones: Beatty: Shoshone family - The death certificate of Dave Shoshone identified him as having resided in Beatty. He was killed in a car accident (rearended by another car) on Highway 29 traveling between Lathrop Wells and Death Valley. His personal effects were taken to Spike and Bombo Cottonwood of Beatty. [Inquest File, Nye County Recorder's Office, December 4, 1961]

1963 Whiterock Spring area: rock shelters: glass trade beads and abalone pendants Rodgers Rock Shelter, on Ranier Mesa, about two miles from Whiterock Spring, was excavated by Frederick C. Worman in 1962. Among the artifacts recovered were two types of beads: (1) 17 white opaque glass beads identified as "of the type known as the 'seed' bead, an early trade item in the north-west...introduced into the Plains area before 1850," and (2) 8 dark blue glass beads known as "Hudson's Bay Beads" that were "among the earliest used in the Canadian trade. These beads could have been introduced into NTS at any time after 1850 through trade with tribes to the north." The shelter also contained 12 pieces of abalone shell, indicating trade connections with the coast. [Worman, 1963:pages not numbered]

1964 Shoshone: Beatty: law enforcement: Cottonwood family - Charles U. Cottonwood, a local Native American man, was sworn in as a deputy sheriff for the Beatty area. [Oath of Office, Nye County Recorder's Office, December 8, 1964]

1964 Tippipah Spring: historical structures - As of 1964, there was a stable standing at Tippipah Spring with a harness hanging inside. "The structures at Tippapah Spring are said to have been part of a stage station. Perhaps the harness hanging in the weathered stable was once used on stage-line horses." [NTS News, vol. VIII, no. 2, January 24, 1964:4-5]

1964 Whiterock Spring: historical structures - As of 1964, there was a stone house standing at Whiterock Spring. "The house at White Rock Spring is blended into the landscape...The roof is a continuation of the hillside into which the house is built, and the thick white rock walls are as rugged as the clifts from which the springs flow. Heavy logs brace the long log ridgepole...and smaller log rafters support a thick layer of the native brush holding the dirt roof." [NTS News, January 24, 1964:5]

1970 Nye County: population - According to the 1970 census, Nevada had a total population of 488,738 and a Native American population of 7,933. Nye County had a population of 5,599 and a Native American population of 227. The 1970 census divided southern Nye County into two districts: Beatty township, which had a population of 1,131, and Pahrump, which had a population of 963. [Department of Commerce, Bureau of the Census, 1973:30-12,30-24,30-51]

1971 Native Americans: Pahrump: Chief Tecopa - In a photograph of a ceremony dedicating a monument to Chief Tecopa at the Pahrump cemetery, two of the persons seated on the speakers' platform were grandnieces of Chief Tecopa as well as local residents, Alice Jim and Cynthia Lynch. Cynthia Lynch is a "full blood Pahute and a member of the 'Jim' family." [Lynch, 1971:191]

1980 Nye County: population - According to the 1980 census, Nevada had a total population of 800,493 and a Native American population of 13,205 . Nye County had a total population of 9,048 and a Native American population of 352 . Beatty township had a population of 3,524 and Pahrump township had a population of 1,358. [Department of Commerce, Bureau of the Census, 1981:30-8,30-10,30-9.x] 
1980s Paiutes and Shoshones: Owens Valley: contemporary groupings - The population of the Lone Pine colony is partly Shoshone, the descendants of Panamint Shoshone groups from Saline Valley, Death Valley, and the slopes of the Sierra Nevada and Coso Range. [Liljeblad and Fowler, 1986:415]

\section{Twentieth Century, No Exact Date}

- Yucca Mountain: mining activities - A moderate amount of ceramic silica was produced from the northwest end of Yucca Mountain. [Comwall, 1972:3-6]

- Mining: Kawich (Gold Reed) district - There was small production of gold and silver. [Cornwall, 1972:38]

- Nevada Test Site: mining activities - Mining districts within the Nevada Test Site included Antelope Springs, 30 miles east of Goldfield; Cactus Springs; Gold Crater; Goldfield; Kawich; Mellan Mountain; Oak Spring; Wahmonie; Wellington; and Wilsons. [Kral, 1951:7]

- Nevada Test Site: mining activities - Operating mines within the Nevada Test Site included the Hornsilver mine at the short-lived town of Wahmonie, four miles west of Cane Spring; the Climax Tungsten mine at the north end of Yucca Flat; a cinnabar mine and retort on Mine Mountain; and galena deposits at the Groom mine. [Worman, 1969:8]

- Mine Mountain: mining activities - There were mining activities on Mine Mountain, but no archaeological reconnaissance had been done in this area. [Pippin and Zerga, 1983:60]

- Cane Spring area: mining activities - In addition to the Hornsilver mine, there were two travertine quarrying operations in the southern portion of the Specter Range and a copper prospect known as the Lucky group in the Striped Hills. Both areas are south of Skull Mountain. [Kral, 1951:207]

- Oasis Valley area: mining activities - There were two major mines in the Pioneer district, northwest of Beatty: the Mayflower mine (worked through the 1930s) and the Pioneer mine (worked through 1949). [Kral, 1951:37-38]

- Oasis Valley area: mining activities: water resources - Several mills were built in the Beatty area because of the ready water in the Amargosa River. One was built as late as 1938. [Kral, 1951:40]

Cactus Springs area: mining activities - Considerable development work was performed in the Cactus Springs area, but not much production. Turquoise was discovered in 1901. Silver was discovered in 1904. The Cactus silver mine operated around 1920. [Kral, 1951:40-42]

- Oasis Valley area: mining activities - Areas with mines in the vicinity of Oasis Valley included Beatty, Bare Mountain, Carrara, Big Dune, and Lee. The Telluride district included Bare Mountain, Crater Flat, the southeast end of Yucca Mountain, and part of the Amargosa Desert. [Kral, 1957:60]

Oasis Valley: mining activities - The Fluorine district, including the Diamond Queen mine, was on the east side of Bare Mountain, 13 miles southeast of Beatty. "Present ruins indicate that at one time this was a fair-sized mining camp built at considerable expense." [Kral, 1951:63] 
- Wahmonie: mining activities - The Wahmonie district was located 50 miles east of Beatty and five miles northeast of Cane Spring. [Kral, 1951:206]

- Topopah Spring: ranching - There is debris from ranching activities at Topopah Spring, including several water tanks. [Worman, 1969:15-16]

- Nevada Test Site: mining activities - Mining districts within the Tonopah Bombing and Gunnery Range include Antelope Springs, Cactus Springs, Gold Crater, Goldfield, Kawich, Mellan Mountain, Oak Spring, Wahmonie, Wellington, and Wilsons. [Kral, 1951:7] 




Map 6. Some of the Archaeological Sites on the Nevada Test Site (Worman, 1969). 


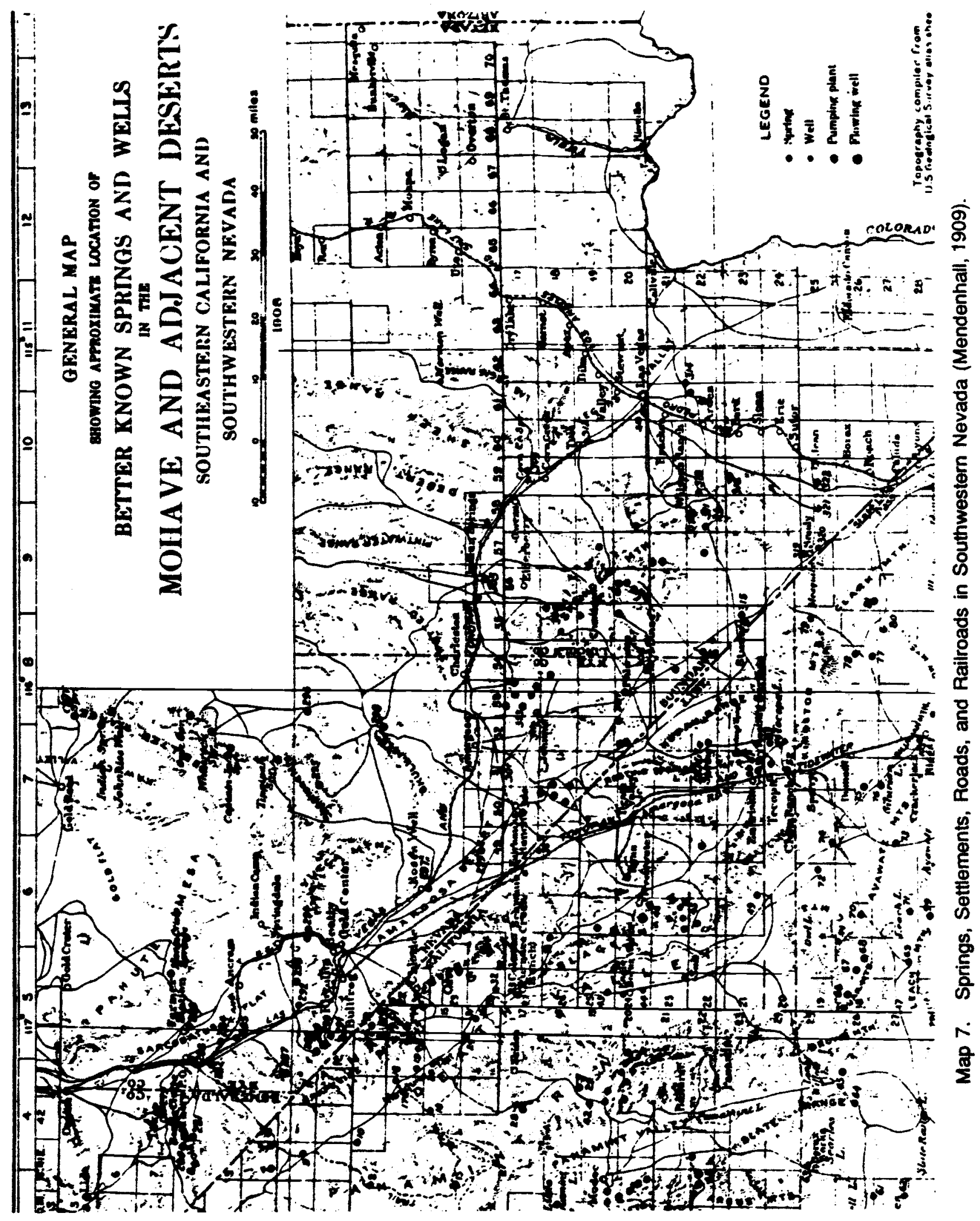




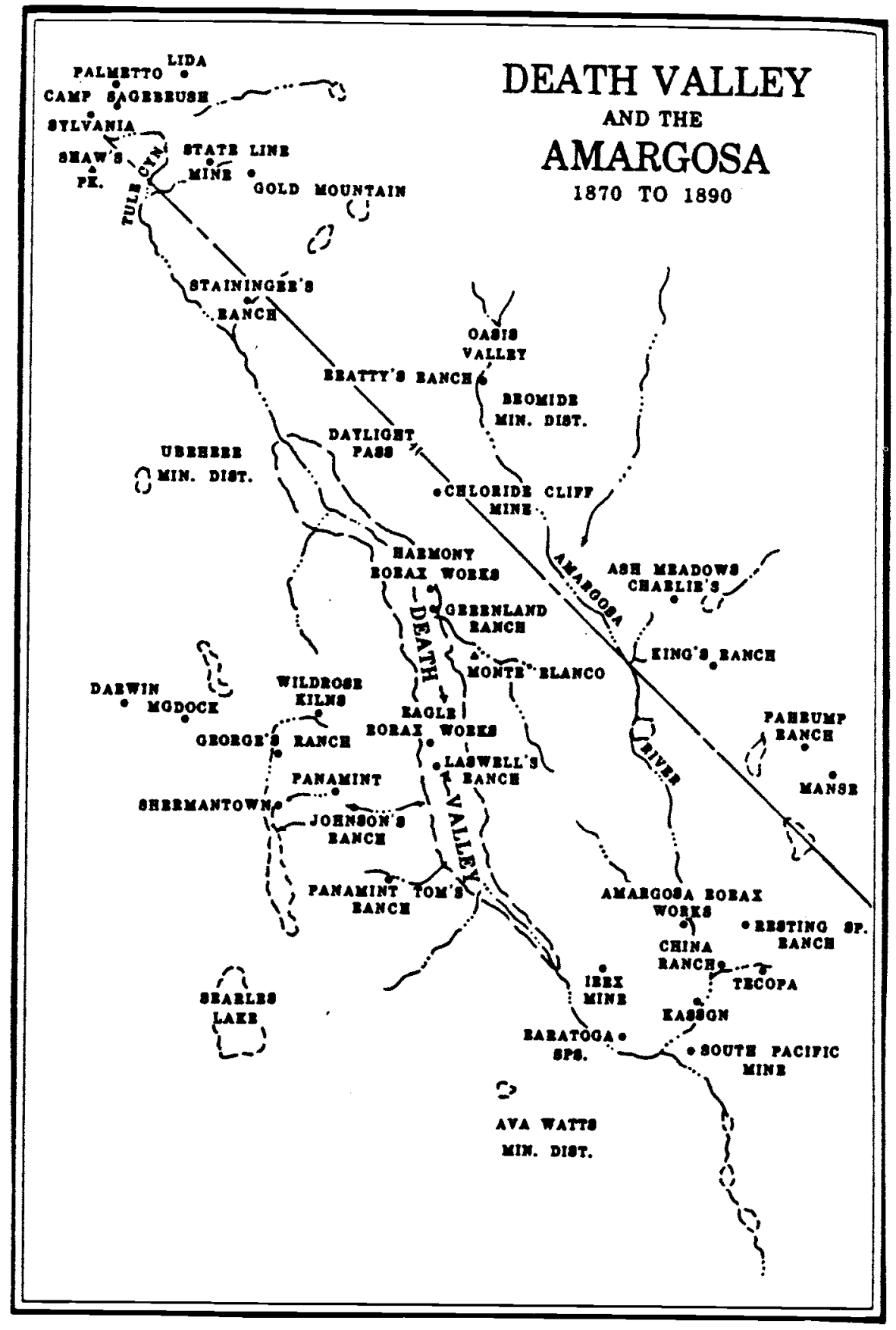

Map 8. Ranches, Mines, and Settlements in the Amargosa Region, 1870-90 (Lingenfelter, 1986). 


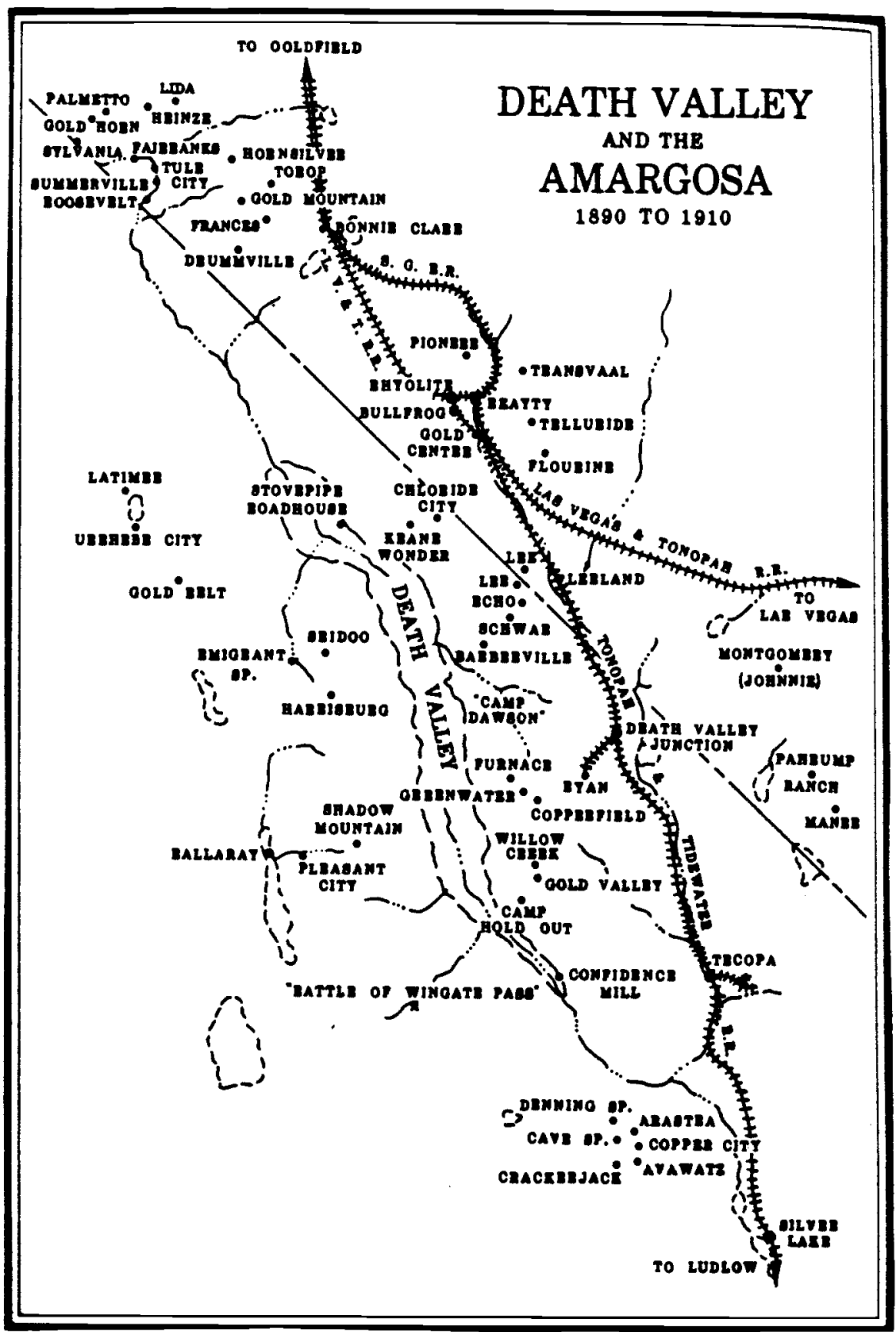

Map 9. Towns, Mining Camps, and Railroads in the Amargosa Region, 1890-1910 (Lingenfelter, 1986). 


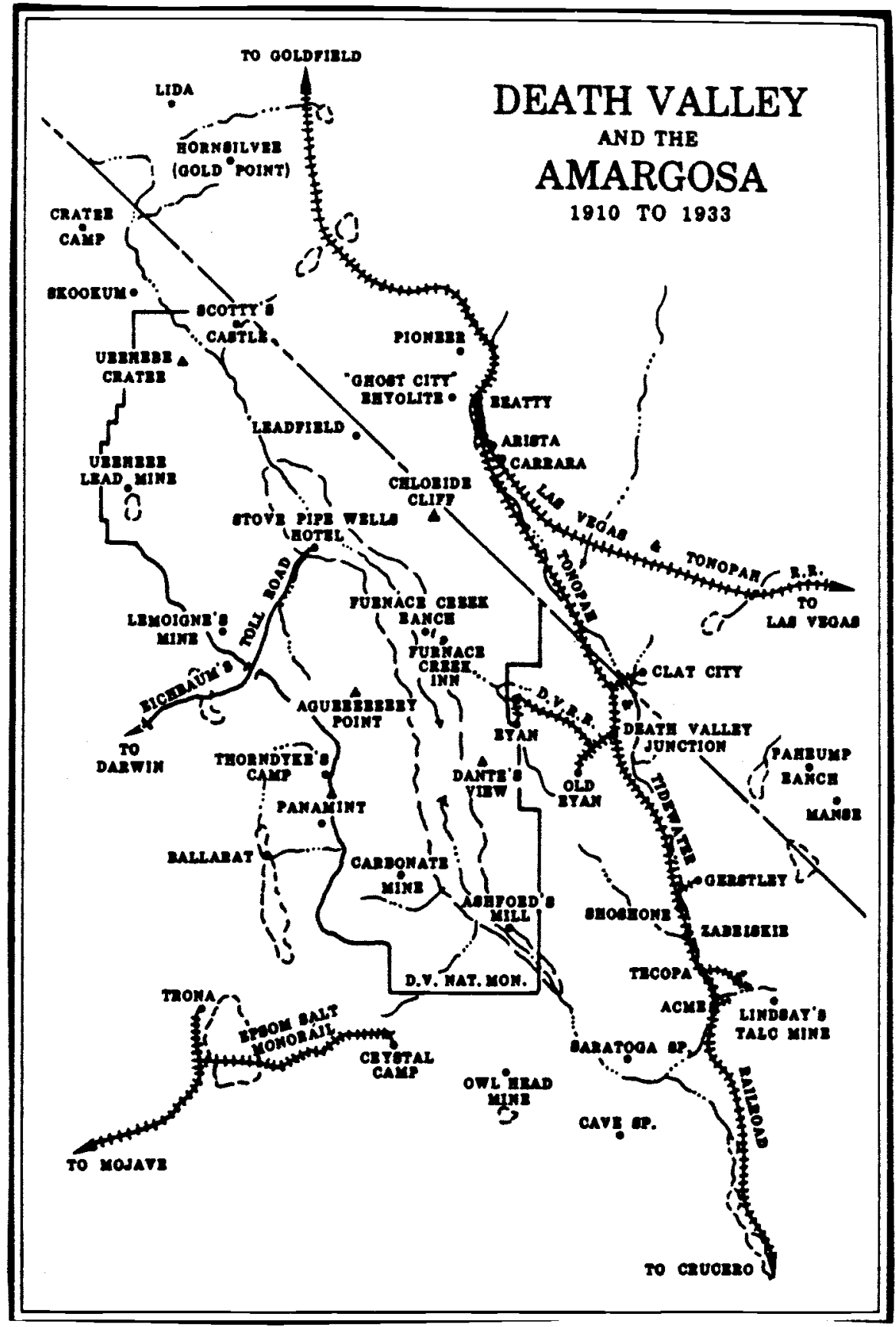

Map 10. Towns, Mining Camps, and Railroads in the Amargosa Region, 1910-33 (Lingenfelter, 1986). 


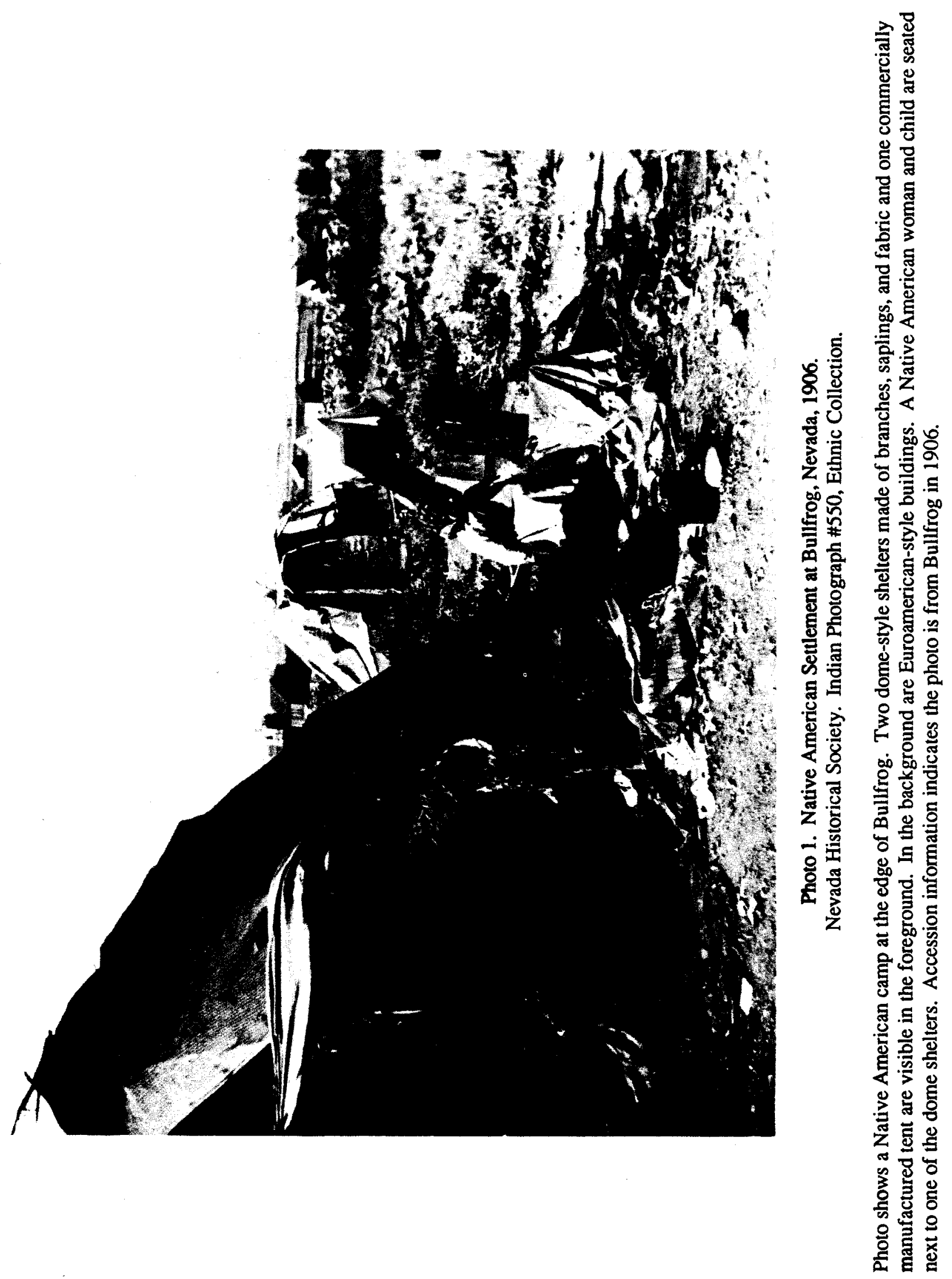




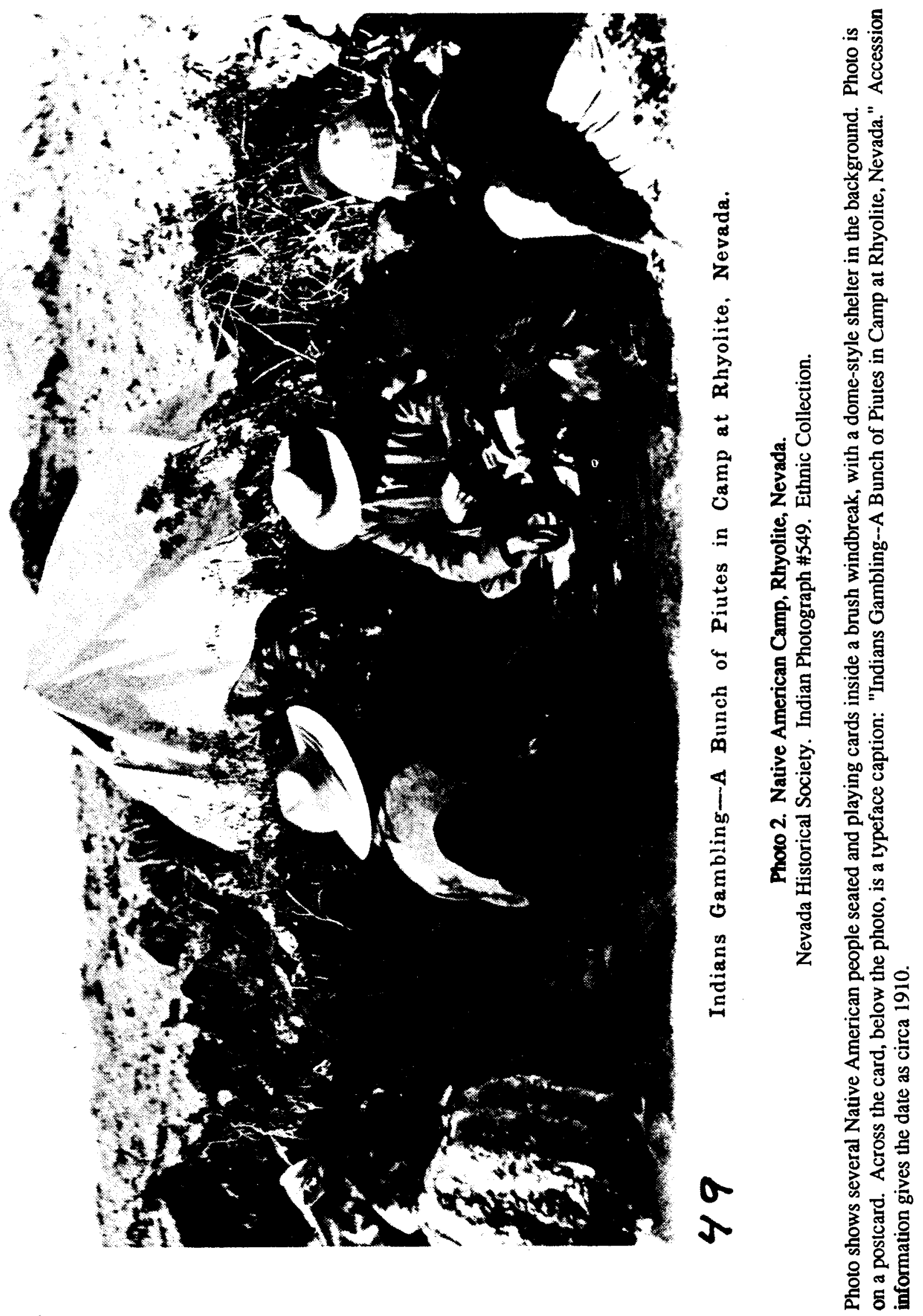




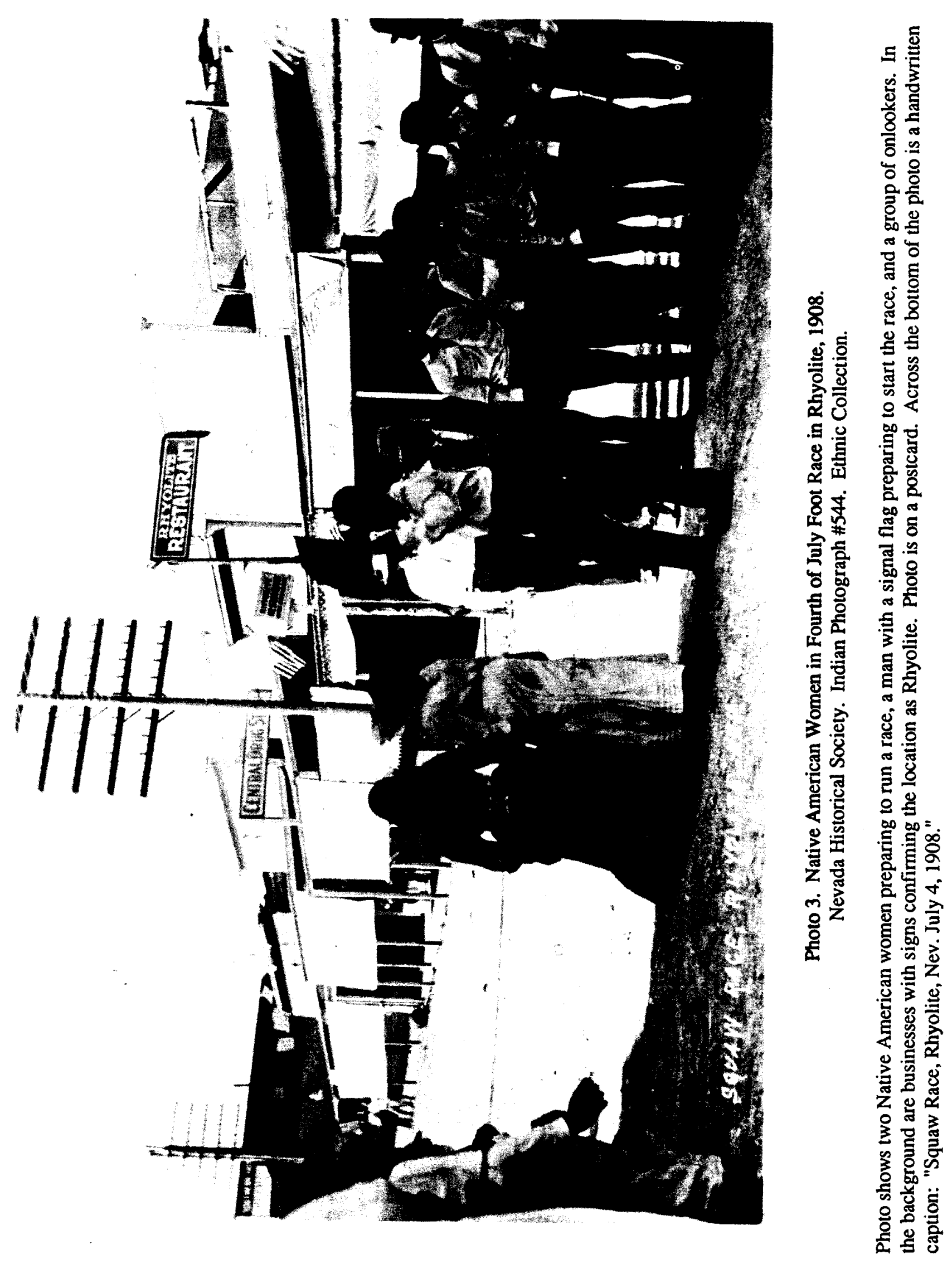




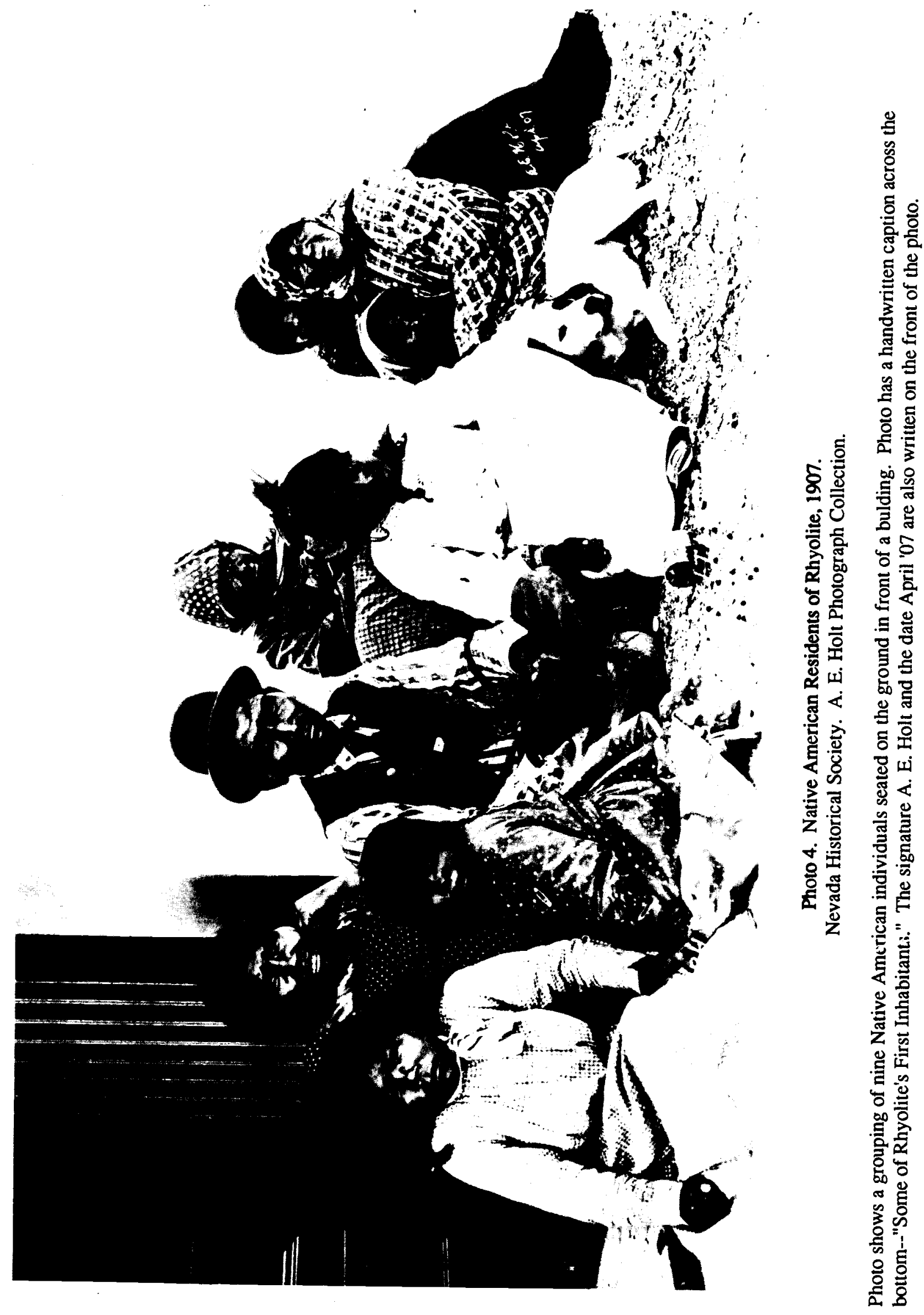






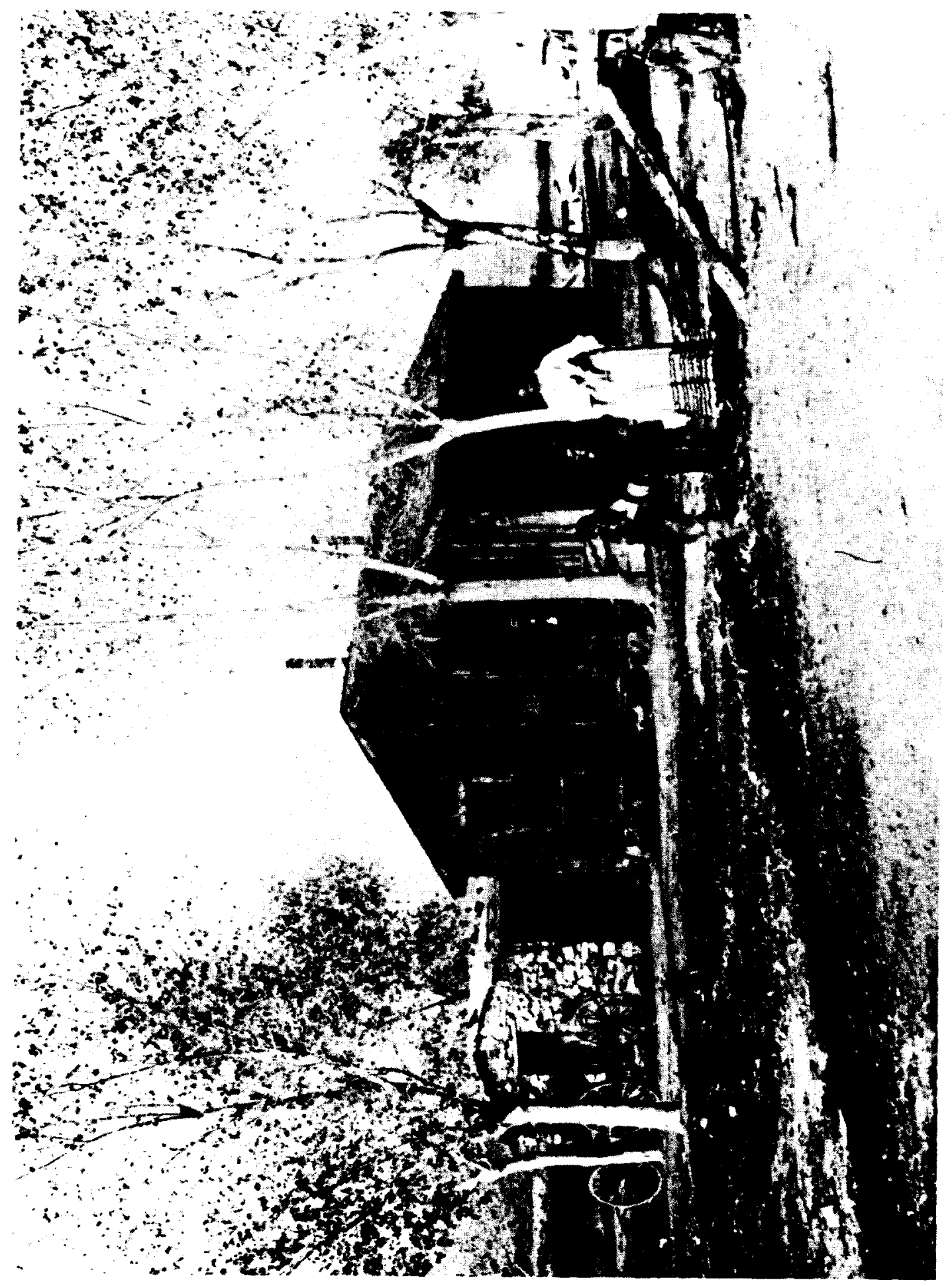

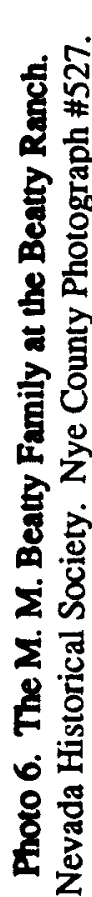

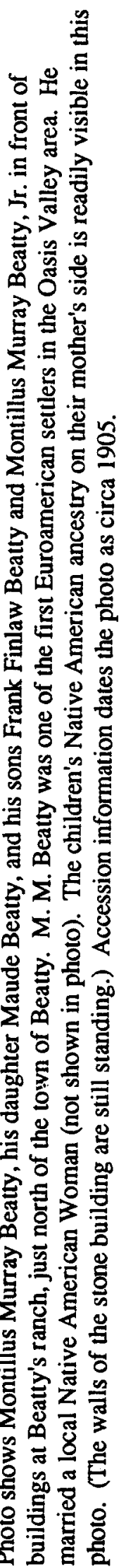




\section{Bibliography}

\section{Books, Journal Articles, and Government Publications}

Anonymous

1928 "One Strike of Real Importance Made at Nevada's New Camp," Engineering and Mining Journal 125(11):467.

1928b "One Wahmonie Citizen in Clover," Engineering and Mining Journal 125(21):862.

Ashbaugh, Don

1963 Nevada's Turbulent Yesterday: A Study in Ghost Towns. Westernlore Press.

Belden, L. Burr

1954 Death Valley Heroine and Source Accounts of the 1849 Travelers. San Bernardino: Inland Printing and Engraving Company.

1976 Mines of Death Valley. Glendale: La Siesta Press.

Bowers, Martha $\mathrm{H}$. and Hans Muessig

1982 History of Central Nevada: An Overview of the Battle Mountain District. Cultural Resource Series No. 4. Reno: Bureau of Land Management, Nevada.

Boyer, Florence

1967 Las Vegas: My Home for Sixty Years. Reno: Oral History Program, University of Nevada.

Brooks, Thomas W.

1970 By Buckboard to Beatty: The California-Nevada Desert in 1886. Edited, with introduction and notes by Anthony L. Lehman. Los Angeles: Dawson's Bookshop.

Browne, J. Ross

1869 Resources of the Pacific Slope. New York: D. Appleton and Company.

Bureau of the Census, Department of Commerce

1913a Thirteenth Census of the United States. Vol. 3. Population. 1910. NebraskaWyoming. Washington, D.C.: U.S. Government Printing Office.

1913b Thirteenth Census of the United States. [Census Enumeration for Nevada (microfilm)].

1921 Fourteenth Census of the United States Taken in the Year 1920. Population. Washington, D.C.: U.S. Government Printing Office.

1932 Fifteenth Census of the United States: 1930. Population. Vol. 3. Part 2: Montana-Wyoming. Washington, D.C: U.S. Government Printing Office.

1943 Sixteenth Census of the United States: 1940. Population. Vol. 2. Characteristics of the Population. Part 4: Minnesota-New Mexico. Washington, D.C.: U.S. Government Printing Otfice. 
1952 Seventeenth Census of the United States: 1950. Characteristics of the Population. Vol. 2. Part 28: Nevada. Washington, D.C.: U.S. Government Printing Office.

1961 Eighteenth Census of the United States: 1960. Characteristics of the Population. Vol. 3. Part 30: Nevada. Washington, D.C.: U.S. Government Printing Office.

1973 Nineteenth Census of the United States: 1970. Characteristics of the Population. Vol. 1. Part 30: Nevada. Washington, D.C.: U.S. Government Printing Office.

1981 Twentieth Census of the United States: 1980. Characteristics of the Population. Vol. 1. Part 30: Nevada. Washington, D.C.: U.S. Government Printing Office.

Busby, Colin I., John M. Findlay, and James C. Bard

1979 A Culture Resource Overview of the Bureau of Land Management Coleville, Bodie, Benton, and Owens Valley Planning Units, California. Oakland: Basin Research Associates, for the U.S. Department of the Interior.

Carison, Helen S.

1974 Nevada Place Names: A Geographical Dictionary. Reno: University of Nevada.

Census Office, Department of the Interior

1870 Ninth Census. Vol. 1. The Statistics of the Population of the United States. Washington, D.C.: U.S. Census Printing Office.

1890 Census Bulletin: Population of Nevada. Washington, D.C.: U.S. Census Printing Office.

1891 Population of the United States by Minor Civil Divisions. The Eleventh Census.

1901 a Census Reports. Vol. 1. Twelth Census of the United States, Taken in the Year 1900. Population. Pant 1. Washington, D.C.: U.S. Census Printing Office.

1901b Census Enumeration for Nevada (microfilm).

ClA (Commissioner of Indian Affairs)

Reports of Nevada Indian Agents to the Commissioner of Indian Affairs, the U.S. Secretary of the Interior, and the U.S. Congress.

1860 Report of the Commissioner of Indian Affairs Accompanying the Annual Report of the Secretary of the Interior for the Year 1859. Washington, D.C. George Bowman, Printer. pp. 362-376.

1865 Report of the Commissioner of Indian Affairs for the Year 1864. Washington, D.C.: U.S. Government Printing Office. pp. 139-149.

1866 Report of the Commissioner of Indian Affairs for the Year 1866. Washington, D.C.: U.S. Government Printing Office. pp. 113-121.

1868 Report on Indian Affairs by the Acting Commissioner, for the Year 1867. Washington, D.C.: U.S. Government Printing Office. pp. 168-173. 
1872 Report of the Commissioner of Indian Affairs to the Secretary of the Interior for the Year 1872. Washington, D.C.: U.S. Government Printing Otfice. pp. 282-

287.

1873 "Letter from the Acting Secretary of the Interior relative to the condition of the Pi-Ute Indians," House Executive Documents No. 1565. Exec. Doc. No. 66. Washington D.C.: U.S. Government Printing Office. pp. 1-4.

1874a "Letter from the Secretary of the Interior transmitting...information relative to the Indian Agencies in Nevada," Senate Executive Documents No. 1580. Exec. Doc. No. 42. Washington, D.C.: U.S. Government Printing Office. pp 3-17.

1874b "Letter from the Acting Secretary of the Interior in relation to the condition and wants of the Ute Indians of Utah; the Pai-Utes of Utah, Northern Arizona, Southern Nevada, and Southeastern California; the Go-si Utes of Utah and Nevada; the Northwestern Shoshones of Idaho and Utah, and the Western Shoshones of Nevada," House Executive Documents No. 1610. Exec. Doc. No. 157. Washington, D.C.: U.S. Government Printing Otfice. pp. 1-35.

1874c Annual Report of the Commissioner of Indian Affairs to the Secretary of the Interior for the Year 1874. Washington, D.C.: U.S. Government Printing Otfice. pp. 278-285.

1875 Annual Report of the Commissioner of Indian Affairs to the Secretary of the Interior for the Year 1875. Washington, D.C.: U.S. Government Printing Otfice. pp. 336-343.

1876 Annual Report of the Commissioner of Indian Affairs to the Secretary of the Interior for the Year 1876. Washington, D.C.: U.S. Government Printing Otfice. pp. 114-119.

1877 Annual Report of the Commissioner of Indian Affairs to the Secretary of the Interior for the Year 1877. Washington, D.C.: U.S. Government Printing Office. pp. 150-153.

1878 Annual Report of the Commissioner of Indian Affairs to the Secretary of the Interior for the Year 1878. Washington, D.C.: U.S. Government Printing Otfice. pp. 102-107.

1879 Annual Report of the Commissioner of Indian Affairs to the Secretary of the Interior for the Year 1879. Washington, D.C.: U.S. Government Printing Otfice. pp. 109-112.

1880 Annual Report of the Commissioner of Indian Affairs to the Secretary of the Interior for the Year 1880. Washington, D.C.: U.S. Government Printing Office. pp. 123-129.

1881 Annual Report of the Commissioner of Indian Affairs to the Secretary of the Interior for the Year 1881. Washington, D.C.: U.S. Government Printing Office. pp. $130-134$.

1882 Annual Report of the Commissioner of Indian Affairs to the Secretary of the Interior for the Year 1882. Washington, D.C.: U.S. Government Printing Office. pp. 117-121. 
1884 Annual Report of the Commissioner of Indian Affairs to the Secretary of the Interior for the Year 1884. Washington, D.C.: U.S. Government Printing Office. pp. 126-131.

1887 Annual Report of the Commissioner of Indian Affairs to the Secretary of the Interior for the Year 1887. Washington, D.C.: U.S. Government Printing Office. pp. $162-166$.

1889 Fitty-Eighth Annual Report of the Commissioner of Indian Affairs to the Secretary of the Interior 1889. Washington, D.C.: U.S. Govemment Printing Office. pp. 504-507, 522-523.

1890 Fitty-Ninth Annual Report of the Commissioner of Indian Affairs to the Secretary of the Interior for the Year 1890. Washington, D.C.: U.S. Government Printing Office. pp. 147-154.

1891 Sixtieth Annual Report of the Commissioner of Indian Affairs to the Secretary of the Interior for the Year 1891. Washington, D.C.: U.S. Government Printing Office. pp. 298-305.

1892 Sixty-First Annual Report of the Commissioner of Indian Affairs to the Secretary of the Interior for the Year 1892. Washington, D.C.: U.S. Government Printing Otfice. pp. 319-327.

1895 Annual Report of the Commissioner of Indian Affairs, 1894. Washington, D.C.: U.S. Government Printing Office. pp. 199-205.

1897 Annual Reports of the Department of the Interior for the Fiscal Year ended June 30, 1897. Report of the Commissioner of Indian Affairs. Washington, D.C.: U.S. Government Printing Office. pp. 186-191.

1905 Annual Reports of the Department of the Interior for the Fiscal Year ended June 30, 1904. Indian Affairs. Part I. Report of the Commissioner and Appendixes. Washington, D.C.: U.S. Government Printing Office. pp. 240-249.

1906 Annual Reports of the Department of the Interior for the Fiscal Year ended June 30, 1905. Indian .Affairs. Part I. Washington, D.C.: U.S. Government Printing Office. pp. 254-260.

1907 Annual Reports of the Department of the Interior 1906. Indian Affairs: Report of the Commissioner and Appendixes. Washington, D.C.: U.S. Government Printing Office. pp. 269-275.

Cline, Gloria Griffen

1963 Exploring the Great Basin. Norman: University of Oklahoma.

Colley, Charles $\mathrm{C}$.

1973 "The Struggle of Nevada Indians to Hold Their Lands 1847-1870," The Indian Historian 6(3):5-17.

Cook, Fred S.

nd Historic Legends of Nye and Esmeralda Counties. Pahrump, Nevada: The Printery. 
Cornwall, Henry R.

1972 Geology and Mineral Resources of Southem Nye County, Nevada. Bulletin 77. Nevada Bureau of Mines and Geology. Reno: University of Nevada.

Correll, J. Lee, Editha L. Watson, and David M. Brugge

1969 Navajo Bibliography with Subject Index. Window Rock, Arizona: The Navajo Tribe.

Couch, Bertrand F. and Jay Carpenter

1943 "Nevada's Metal and Mineral Production," University of Nevada Bulletin.

Geology and Mining Series No. 38. Reno: Nevada State Bureau of Mines.

Coville, Frederick Vernon

1892 "The Panamint Indians of California," American Anthropologist 5(4):351-361.

Crum, Beverty et al.

1976 Newe: A Westem Shoshone History. Reno: Inter-Tribal Council of Nevada.

Davis, Sam P. (ed.)

1913 History of Nevada. Las Vegas: Nevada Publications.

D'Azevedo, Warren L.

1986 Handbook of North American Indians. Vol. 11: Great Basin. Washington, D.C.: Smithsonian Institution.

De Quille, Dan (William Wright)

1947 The Big Bonanza (reprint of 1876 original). New York: Alfred A. Knopf.

DOE (Department of Energy)

1986 Environmental Assessment: Yucca Mountain Site, Nevada Research and Development Area, Nevada. 3 vols. Washington, D.C.: U.S. Department of Energy.

Doherty, John

1974 "The History of the Settling of the Manse Ranch and Territory," Nevada Historical Society Quarterly, vol. 17, no. 3, Fall 1974. pp. 165-168.

Downs, James F.

1966 The Significance of Environmental Manipulation in Great Basin Cultural Development," The Current Status of Anthropological Research in the Great Basin: 1964. Warren L. d'Azevedo, Wilbur A. Davis, Don D. Fowler, and Wayne Suttles, eds. Reno: Desert Research Institute. pp. 39-56.

Drover, Christopher E.

1985 "Navajo Settlement and Architecture in Southem California," Joumal of California and Great Basin Anthropology 7(1):46-57. 
Dutcher, B.H.

1893 "Pinon Gathering among the Panamint Indians," American Anthropologist 6(4):377-380.

Earl, Phillip I.

1986 This Was Nevada. Reno: Nevada Historical Society.

Elliott, Russell R. and Helen J. Poulton

1963 Writings on Nevada: A Selected Bibliography. Reno: University of Nevada.

Euler, Robert C. and Catherine S. Fowler

1966 Southern Paiute Ethnohistory. Salt Lake City: University of Utah.

Anthropological Papers No. 78 (Glen Canyon Series No. 28).

Folkes, John Gregg

1964 Nevada's Newspapers; A Bibliography: A Compilation of Nevada History, 18541964. Reno: University of Nevada

Fowler, Catherine

1982 "Settlement Patterns and Subsistence Systems in the Great Basin: the Ethnographic Record," Man and Environment in the Great Basin. Society for American Archaeology (SAA) Paper No. 2. pp. 121-138. David B. Madsen and James F. O'Connell, eds. Washington, D.C.: SAA.

Fowler, Don D. and Catherine S. Fowler

1971 Anthropology of the Numa: John Wesley Powell's Manuscripts on the Numic Peoples of Western North America, 1868-1880. Washington, D.C.: Smithsonian Institution Press.

Forbes, Jack D.

1967 Nevada Indians Speak. Reno: University of Nevada Press.

Fremont, John Charles

1845 Report of the Exploring Expedition to the Rocky Mountains in the Year 1842 and to Oregon and North California in the Years 1843-44. Washington, D.C.: Gales and Seaton.

Gianella, Vincent P. and Robert W. Prince

1945 Bibliography of Geologic Literature of Nevada and Bibliography of Geologic Maps of Nevada Areas. University of Nevada Bulletin. Geology and Mining Series No. 43. Vol. 39, no. 6. Reno: University of Nevada.

Greene, Linda W.

1981 Historic Resource Study: A History of Mining in Death Valley National Monument. Denver: National Park Service, U.S. Department of the Interior. 
Grosscup, Gordon L.

1977 "Notes on the Boundaries and Culture of the Panamint Shoshone and Owens Valley Paiute," Great Basin Anthropological Papers 35:109-146. Berkeley: University of California.

Haten, LeRoy R. and Ann W. Hafen

1954 Joumals of the Forty-Niners, Salt Lake to Los Angeles. The Far West and Rockies Series, vol. II. Glendale: The Arthur H. Clark Company.

1957 Central Route to the Pacific by Gwinn Harris Heap. The Far West and Rockies Series, vol. VIl. Glendale: The Arthur H. Clark Company.

1961 The Far West and Rockies: General Analytical Index to the Fifteen Volume Series and Supplement to the Journals of Forty-Niners, Salt Lake to Los Angeles. The Far West and Rockies Series, vol. 15. Glendale: The Arthur H. Clark Company.

Hafner, Arabell Lee

1967100 Years on The Muddy. Springvale, Utah: Art City Publishing Company.

Hanes, Richard C.

1982 "Cultural Persistence in Nevada: Current Native American Issues," Joumal of Califomia and Great Basin Anthropology 4(2):203-221.

Hattori, Eugene Mitsuru

1975 Northern Paiutes on the Comstock: Archaeology and Ethnohistory of an American Indian Population in Virginia City, Nevada. Carson City: Nevada State Museum.

Hattori, Eugene M. and Alvin R. McLane

1981 An Archaeological Survey Between Lathrop Wells, Nye County, Nevada and the Nevada Califomia State Line. Desert Research Institute, Social Sciences Technical Report Series No. 22. Reno: Desert Research Institute.

Heap, Gwinn Harris

1957 Central Route to the Pacific. Edited by Leroy R. Hafen and Ann W. Hafen. Glendale: The Arthur H. Clark Company.

Hubbard, Paul B., Doris Bray, and George Pipkin

1965 Ballarat, 1897-1917: Facts and Folklore. Lancaster, California: Paul. B. and Arline B. Hubbard.

Ingalls, G.W.

1913 "Indians of Nevada, 1825 to 1913," The History of Nevada. Sam P. Daris, ed. Las Vegas: Nevada Publications. pp. 20-130. 
Inter-Tribal Council of Nevada

1976 Nuwuvi: A Southem Paiute History. Salt Lake City: University of Utah for InterTribal Council of Nevada.

Jensen, Andrew

1926 "History of the Las Vegas Mission, compiled by Andrew Jensen, Assistant Church Historian, Salt Lake City," Nevada State Historical Society Papers 192526. pp. 115-284.

Johnson, Leroy and Jean Johnson

1987 Escape from Death Valley as told by William Lewis Manley and Other 49ers. Reno and Las Vegas: University of Nevada.

Kelly, Isabel T.

1934 "Southern Paiute Bands," American Anthropologist 36(4):548-560.

1964 Southern Paiute Ethnography. Salt Lake City: University of Utah. Anthropological Papers No. 69.

Kelly, Isabel T. and Catherine S. Fowler

1986 "Southern Paiute," Handbook of North American Indians. Volume 11: Great Basin. Warren L. D'Azevedo, ed. Washington, D.C.: Smithsonian Institution. pp. 368-397.

Kensler, Charles D.

nd Survey of Historic Structures: Southern Nevada and Death Valley. San Francisco: URS/John A. Blume and Associates for the U.S. Department of Energy.

Knack, Martha C. and Omer C. Stewart

1984 As Long As the River Shall Run: An Ethnohistory of Pyramid Lake Indian Reservation. Berkeley: University of Califomia.

Koenig, George

1984 Beyond This Place There Be Dragons: The Routes of the Tragic Trek of the Death Valley 1849ers through Nevada, Death Valley, and on to Southern California. Glendale: The Arthur H. Clark Company.

Kral, Victor $E$.

1951 Mineral Resources of Nye County, Nevada. Reno: University of Nevada Bulletin. Vol. XLV. No. 3. Geology and Mining Series No. 50.

Kroeber, Alfred

1970 Handbook of the Indians of California. Bureau of American Ethnology Bulletin 78. Washington, D.C.: U.S. Government Printing Office. 
Kuykendoll, Jerome K. et al.

1978 United States Indian Claims Commission Final Report. Washington, D.C.: U.S. Government Printing Office.

Laird, Carobeth

1976 The Chemehuevis. Banning, California: Malki Museum Press.

Lawton, Harry W., Philip J. Wilke, Mary DeDecker, and William M. Mason

1976 "Agriculture Among the Paiute of Owens Valley," Journal of California Anthropology. vol. 3, no. 1. pp. 13-50.

Lewis, Georgia

1969 "Jack Longstreet - Southem Nevada gunslinger who lived to be 93 years old," The Nevadan (Sunday magazine), May 18, 1969. pp. 3-5.

Liljeblad, Sven and Catherine S. Fowler

1986 "Owens Valley Paiute," Handbook of North American Indians. Volume 11: Great Basin. Washington, D.C.: Smithsonian Institution. pp. 412-434.

Lincoln, Francis Church

1923 Mining Districts and Mineral Resources of Nevada. Reno: Nevada Newsletter Publishing Company.

Lingenfelter, Richard E.

1986 Death Valley and the Amargosa: A Land of Illusion. Berkeley: University of California.

Lingenfelter, Richard E. and Karen Rix Gash

1984 The Newspapers of Nevada: A History and Bibliography, 1854-1979. Reno: University of Nevada.

Lisle, Betty

1974 "Dad Fairbanks, Desert Pioneer: Part II," The Nevadan (Sunday magazine), January 20, 1974. pp. 3-5.

Long, Margaret

1941 The Shadow of the Arrow. Caldwell, Idaho: Caxton Printers.

Lynch, Denny

1979 A History of Pahrump Valley. Pahrump, Nevada: Denny Lynch.

Lynch, Robert N.

1978 "Cowboys and Indians," Seiected Papers from the 14th Great Basin Anthropological Conference. Donald R. Tuohy, ed. Sicorro, New Mexico:

Ballena Press. pp. 51-59. 
Lyneis, Margaret

1982 "Prehistory in the Southern Great Basin," Man and Environment in the Great Basin. Society for American Archaeology (SAA) Paper No. 2. David B. Madsen and James F. O'Connell, eds. Washington, D.C.: SAA.

Mack, Effie Mona

1936 Nevada: A History of the State from the Earliest Times through the Civil War. Glendale: The Arthur H. Clark Company.

Malouf, Carling

1964 "Ethnohistory in the Great Basin," The Current Status of Anthropological Research in the Great Basin. Warren L. d'Azevedo et al., eds. Reno: Desert Research Institute. pp. 1-38.

Malouf, Carling I. and John M. Findlay

1986 "Euro-American Impact Before 1870," Handbook of North American Indians. Volume 11: Great Basin. Warren L. D'Azevedo, ed. Washington, D.C.: Smithsonian Institution. pp. 499-516.

Manly, William Lewis

1927 Death Valley in '49. Chicago: The Lakeside Press.

Mathews, M.M.

1985 Ten Years in Nevada. Lincoln: University of Nebraska.

Mendenhall, Walter C.

1909 Some Desert Watering Places in Southeastern California and Southwestern Nevada. Water Supply Paper 224. Washington, D.C.: U.S. Geological Survey.

Moore, Ert

1979 Experiences of a Pioneer Educator. Reno: University of Nevada Oral History Project.

Myrick, David F.

1962 Railroads of Nevada and Eastem California. Berkeley: Howell-North Books. Nelson, E.W.

1891 "The Panamint and Saline Valley Indians," American Anthropologist 4(4):371372.

Nusbaumer, Louis

1967 Valley of Salt, Memories of Wine: A Joumal of Death Valley, 1849 by Louis Nusbaumer. George Koenig, ed. Berkeley: Friends of the Bancroft Library, University of California.

Office of the Federal Register

1987 Federal Register, vol. 52, no. 237, December 10, 1987, p. 46842. 
Paher, Stanley W.

1970 Nevada Ghost Towns and Mining Camps. Berkeley: Howell-North Books.

1973 Death Valley Ghost Towns. Las Vegas: Nevada Publications.

Pippin, Lonnie C.

1986 An Overview of Cultural Resources on Pahute and Rainier Mesas on the Nevada Test Site, Nye County, Nevada. Desert Research Institute. Technical Report No. 45. Reno: Desert Research Institute.

Pippin, Lonnie C. (ed.)

1984 Limited Test Excavations at Selected Archaeological Sites in the NNWSI Yucca Mountain Project Area, Southern Nye County, Nevada. Desert Research Institute. Social Sciences Technical Report No. 40. Reno: Desert Research Institute.

Pippin, L., R. Clerico and R. Reno

1982 Cultural Resources Overview for the Nevada Nuclear Waste Storage Investigations, Nevada Test Site, Nye County, Nevada. Las Vegas: U.S. Department of Energy.

Pippin, Lonnie C. and Donald L. Zerga

1983 Cultural Resources Overview for the Nevada Nuclear Waste Storage Investigations, Nevada Test Site, Nye County, Nevada. Las Vegas: U.S. Department of Energy.

Powell, John Wesley and G.W. Ingalls

1874 "Ute, Pai-Ute, Go-SiUte, and Shoshone Indians," Executive Documents of the House of Representatives. Washington D.C.: U.S. Government Printing Office.

Pratt, Addison

1954 "Addison Pratt's Diary;" Journals of the Forty-Niners, Salt Lake to Los Angeles. Far West and Rockies Series. Vol. II. LeRoy R. Hafen and Ann W. Hafen. Glendale: The Arthur H. Clark Company.

Ransome, F.L.

1907 Preliminary Account of Goldfield, Bullfrog and other Mining Districts in Southem Nevada. U.S. Geological Survey Bulletin 303. Washington, D.C.: U.S. Geological Survey.

Rice, C.T.

1906 "The Bullfrog Mining District, Nevada," Engineering and Mining Journal 82:53436.

Ritter, Betsy

1982 Life in the Ghost City of Rhyolite, Nevada. Terra Bella, Califomia: The Terra Bella News. 
Robertson, Frank C. and Beth Kay Harris

1962 Boom Towns of the Great Basin. Denver: Sage Books.

Rusco, Elmer R.

1975 Good Time Coming? Black Nevadans in the Nineteenth Century. Westport, Connecticut: Greenwood Press.

Secretary of the Interior

1862 Report of the Secretary of the Interior. Washington, D.C.: U.S. Government Printing Office.

1873 "Letter from the Acting Secretary of the Interior relative to the condition of the Pi-Ute Indians." House of Representatives, 42nd Congress, 3rd Session. Executive Document No. 66. Washington D.C.: U.S. Government Printing Otfice.

1874 "Letter from the Acting Secretary of the Interior in relation to the condition and wants of the Ute Indians of Utah; the Pai-Utes of Utah, Northern Arizona, Southern Nevada, and Southeastern California; the Go-Si Utes of Utah and Nevada; the Northwestern Shoshones of Idaho and Utah; and the Western Shoshones of Nevada." House of Representatives, 43rd Congress, 1st session. Executive Document No. 157. Washington, D.C.: U.S. Government Printing Office.

Sennett-Walker, Beth

1987 "Changing Times: Panamint Shoshone Response to White Development," Proceedings: First Death Valley Conference on History and Prehistory. Death Valley Natural History Association; Death Valley 49ers; and National Park Service, U.S. Department of the Interior. pp. 79-85.

Smith, Alfred Merritt and William 0 . Vandenburg

1932 Placer Mining in Nevada. Bulletin of Nevada State Bureau of Mines and the U.S. Bureau of Mines. Vol. 24. No. 8. Reno: University of Nevada.

Spears, John R.

1892 Illustrated Sketches of Death Valley and other Borax Deserts of the Pacific Coast. Chicago and New York: Rand McNally and Company.

Spicer, Edward

1957 "Worlds Apart Cultural Differences in the Modern Southwest," Arizona Quarterly 13(3):197-230.

Squires, Charles P. and Delphine A. Squires

1955 Las Vegas Nevada: Its Romance and History.

Steward, Julian $\mathrm{H}$.

1930 "Irrigation without Agriculture," Papers of the Michigan Academy of Sciences, Arts, and Letters 12:149-156. 
1934 "Ethnography of the Owens Valley Paiute," University of California Publications in American Archaeology and Ethnology. Volume XXXIII. 1932-1934. Berkeley: University of California Press. pp. 233-350.

1938 Basin-Plateau Aboriginal Sociopolitical Groups. Bureau of American Ethnology. Bulletin 120. Washington, D.C.: Smithsonian Institution.

1941 "Culture Element Distributions: XIII, Nevada Shoshoni," Anthropological Records vol. 4, no. 2: 209-358.

Stewart, Omer C.

1964 "Tribal Distributions and Boundaries in the Great Basin," The Current Status of Anthropological Research in the Great Basin: 1964. Warren L. D'Azevedo, Wilbur A. Davis, Don D. Fowler, and Wayne Suttles, eds. Reno: Desert Research Institute.

1978 "The Western Shoshone and the U.S. Government, 1863-1950," Selected Papers from the 14th Great Basin Conference. Donald R. Tuohy, ed. Socorro, New Mexico: Ballena Press Publications in Archaeology, Ethnology, and History No. 11. pp. 77-109.

1982 Indians of the Great Basin: A Critical Bibliography. Bloomington: Indiana University.

Stoffle, Richard W.

1987 Native Americans and Nuclear Waste Storage at Yucca Mountain, Nevada: Potential Impacts of Site Characterization Activities. Ann Arbor: University of Michigan, Institute for Social Research.

Stoffle, Richard W. and Henry F. Dobyns (eds.)

1982 Puaxant Tuvip: Utah Indians Comment on the Intermountain Power Project, Utah Section of Intermountain-Adelanto Bipole I Proposal. Kenosha, Wisconsin: University of Wisconsin-Parkside.

Stoffle, Richard, Henry F. Dobyns and Michael J. Evans

1983 Nungwu-Uakapi: Southern Paiute Indians Comment on the Intermountain Power Project Intermountain-Adelanto Bipole I Transmission Line. Kenosha, Wisconsin: University of Wisconsin-Parkside.

Stoffle, Richard W. and Michael J. Evans

1976 "Resource Competition and Population Change: A Kaibab Paiute Ethnohistorical Case," Ethnohistory 23,2:173-197.

Stoffle, Richard W., Michael J. Evans, and Camille L. Harshbarger

1988 Nevada Nuclear Waste Storage Investigations (NNWSI) Project Native American Interpretation of Cultural Resources in the Area of Yucca Mountain, Nevada. Las Vegas: U.S. Department of Energy.

Stoffle, Richard, Michael Evans, and Florence Jensen

1987 Native American Concerns and State of California Low-Level Radioactive Waste Disposal Facility: Mohave, Navajo, Chemehuevi, and Nevada Pajute Responses: Draft Report. Ann Arbor: University of Michigan, Institute for Social Research. 
Stoffle, Richard W., Merle Jake, Pamela Bunte, and Michael J. Evans

1982 "Southern Paiute Peoples' SIA Responses to Energy Proposals," in C. Geisler et al. (eds.), Indian SIA: The Social Impact Assessment of Rapid Resource Development on Native Peoples. Monograph No. 3. Ann Arbor, Michigan: University of Michigan, Natural Resources Sociology Research.

TC-BIA (Technical Cooperation-Bureau of Indian Affairs)

1937a The Nye County Shoshone Project of Nevada (Reese River Valley and Duckwater). Phoenix: Phoenix Area Office, Bureau of Indian Affairs, Division of Extension and Industry.

1937b Survey of the Beatty-Pahrump Area Located in Southwestern Nevada. Phoenix: Phoenix Area Office, Bureau of Indian Affiars, Branch of Soil Conservation.

Train, Percy, James R. Heinrichs, and W. Andrew Archer

1974 Medicinal Uses of Plants by Indian Tribes of Nevada. U.S. Department of Agriculture (1941) reprinted in Paiute Indians IV. New York: Garland Publishing. pp. 53-258.

Thomas, David H., Lorann S. A. Pendleton, and Stephen C. Cappanari

1986 "Western Shoshone," Handbook of North American Indians. Vol. 11: Great Basin. Warren L. D'Azevedo, ed. Washington, D.C.: Smithsonian Institution. pp. 262-283.

Van Valkenberg, Richard F.

1976 "Chemehuevi Notes," Paiute Indians II. New York: Garland Publishing Inc.

Waldorf, John Taylor

1968 A Kid on the Comstock. Berkeley: Friends of the Bancroft Library, University of California.

Warren, Claude N. and Robert H. Crabtree

1986 "Prehistory of the Southwestern Area," Handbook of North American Indians.

Volume 11: Great Basin. Warren L. D'Azevedo, ed. Washington, D.C.:

Smithsonian Institution. pp. 183-193.

Weight, Harold and Lucile Weight

1953 Rhyolite: The Ghost City of Golden Dreams. Twenty-Nine Palms, California: The Calico Press.

1985 Rhyolite: The Ghost City of Golden Dreams. Revised edition. Twenty-Nine Palms, California: The Calico Press.

Wheeler, George M.

1871 Preliminary Report Concerning Explorations and Surveys Principally in Nevada and Arizona. Washington, D.C.: U.S. Government Printing Office.

1875 Preliminary Report upon a Reconnaissance through Southern and SouthEastern Nevada made in 1869. Washington, D.C.: U.S. Government Printing Office. 
Wier, Jeanne E.

1961 "Diary (1908)," The Back Number: The Quarterly of the Nevada Historical Society vol. IV, no. 1. January-March 1961.

Wilke, Philip J. and Harry W. Lawton

1986 The Expedition of Capt. J.W. Davidson from Fort Tejon to the Owens Valley in 1859. Socorro, New Mexico: Ballena Press Publications in Archaeology, Ethnology, and History.

Winter, Joseph C. and Patrick F. Hogan

1986 "Plant Husbandry in the Great Basin and Adjacent Northern Colorado Plateau," Anthropology of the Desert West: Essays in Honor of Jesse D. Jennings. University of Utah Anthropological Papers, No. 110, pp. 117-144. Salt Lake City: University of Utah.

Worman, Frederick C.

1963 Anatomy of the Nevada Test Site. Los Alamos: University of California.

1969 Archaeological Investigations at the U.S. Atomic Energy Commission's Nevada Test Site and Nuclear Rocket Development Station. Los Alamos: Los Alamos Scientific Laboratory of the University of California.

Zanjani, Sally

1987 "Jack Longstreet in the Death Valley Region," Proceedings: First Death Valley Conference on History and Prehistory. Death Valley Natural History Association, Death Valley 49ers, and National Park Service, U.S. Department of the Interior. pp. 44-51.

1988 Jack Longstreet: Last of the Desert Frontiersmen. Athens, Ohio: Swallow Press, Ohio University Press.

\section{Nye County Government Documents}

1909 Inquest of Indian Henry.

1911 Inquest of Charles Tecopa.

1924 State of Nevada vs. Mike Hughes, Defendant.

1931 Death Certificate of Fannie Longstreet.

1932 State of Nevada vs. Fred E. Lea and Mike Hughes, Defendants.

1959 Oath of Office. Deputy Sheriff Joseph Strozzi.

1961 Inquest of Dave Shoshone

1963 Oath of Otfice. Deputy Sheriff Charles U. Cottonwood. 


\section{Unpublished Manuscripts and Taped Interviews}

Beatty, M.M., Jr.

1968 Taped interview with M.M. Beatty, Jr. 1968. Manuscript Collection. Nevada Historical Society. Reno.

Creel, Lorenzo D.

1917 Testimony taken in connection with a vested right of Ash Meadows Charley. September 29, 1917. Lorenzo D. Creel Collection. Special Collections. University of Nevada-Reno.

1917 Letter to Lorenzo Creel from William G. Morris. December 28, 1917. Lorenzo D. Creel Collection. Special Collections. University of Nevada-Reno.

1918 Letter to William G. Morris from Lorenzo Creel. January 3, 1918. Lorenzo D. Creel Collection. Special Collections. University of Nevada-Reno.

1918 Letter to J.G. Scrugham, State Engineer, from Lorenzo Creel. January 3, 1918. Lorenzo D. Creel Collection. Special Collections. University of Nevada-Reno.

1918 Letter to H. H. Palmer from L. A. Dorrington and Lorenzo D. Creel. February 16, 1918. Lorenzo D. Creel Collection. Special Collections. University of Nevada-Reno.

1918 Letter to Lorenzo Creel from William G. Morris. February 24, 1918. Lorenzo D. Creel Collection. Special Collections. University of Nevada-Reno.

1918 Letter to William G. Morris from Lorenzo D. Creel. March 3, 1918. Lorenzo D. Creel Collection. Special Collections. University of Nevada-Reno.

1918 Letter to Marguerite David from L. A. Dorrington and Lorenzo D. Creel. March 4, 1918. Lorenzo D. Creel Collection. Special Collections. University of NevadaReno.

1920 Letter to L. A. Dorrington from William G. Morris. November 9, 1920. Lorenzo D. Creel Collection. Special Collections. University of Nevada-Reno.

Application for Permit to Appropriate the Public Waters, by William G. Morris. Undated. Lorenzo D. Creel Collection. University of Nevada-Reno.

Letter to L. A. Dorrington from Lorenzo Creel. Undated. Lorenzo D. Creel Collection. Special Collections. University of Nevada-Reno.

Crowell, Jack and Maude Crowell

1988 Taped interview with Jack and Maude Crowell. Beatty.

Crum, Steven James

1983 "The Westem Shoshone of Nevada and the Indian New Deal." University of Utah: Ph.D. dissertation. 
Hittman, Michael

1973 "Ghost Dances, Disillusionment and Opiate Addiction: An Ethnohistory of Smith and Mason Valley Paiutes." University of New Mexico: Ph.D. dissertation manuscript.

Little Beaver, Curtis

1988 Taped interview with Curtis Little Beaver. Tonopah.

Sadovich, Maryellen Vallier Sadovich

nd "A History of Southern Nevada." Manuscript in collection of the Nevada Historical Society.

\section{Photographs}

1906 Bullfrog, Nevada. Indian Photograph \#550. Ethnic File. Nevada Historical Society. Reno.

1907 "Some of Rhyolite's First Inhabitants," April 1907. A.E. Holt, photographer. A.E. Holt Collection. Nevada Historical Society. Reno.

1908 "Squaw Race, Rhyolite Nevada. July 4, 1908." Indian Photograph \#544. Ethnic File. Nevada Historical Society. Reno.

1932-3 Beatty Jr. High School class, 1932-33. Palsgrove Collection. Photo File 309. Central Nevada Historical Society.

1938-9 Beatty School class of 1938-39. Photo Collection of Calvin Chloe Lisle. Beatty. "Indians Gambling-A Bunch of Piutes in Camp at Rhyolite, Nevada." A.E. Holt, photographer. Circa 1910. Nye County Photograph \#549. Nevada Historical Society. Reno.

- "Indians near Beatty" circa 1910. Indian Photograph \#555. Ethnic File. Nevada Historical Society. Reno.

- "Indians in Beatty." Indian Photograph \#553. Ethnic File. Nevada Historical Society. Reno.

"Wikiup ruins below Capt. Jack Cave; Forty Mile Canyon." Photo by S. M. Wheeler. Fortymile Canyon File. Photograph \#813. Nevada Historical Society.

Chief Tecopa playing pool with Sam Yount at Goodsprings, Pahrump. Photo credited to Della Fisk. Published in Paher (1970), p. 327. 


\section{Newspaper Articles}

Beatty Bullfrog Miner

1905 "Fourth at Beatty," Beatty Bullfrog Miner, vol. 1, no. 13, June 17, 1905, p. 6, col. 3.

1905 "Fourth at Beatty," Beatty Bullfrog Miner, vol. 1, no. 15, July 1, 1905, p. 3 (entire p.).

1905 "Breyfogle Again," Beatty Bullfrog Miner, vol. 1, no. 15, July 1, 1905, p. 5, col. 1.

1905 "Echoes from the 4th," Beatty Bullfrog Miner, vol. 1, no. 17, July 15, 1905, p. 3, col. 1.

1905 "Oak Springs," Beatty Bullfrog Miner, vol. 1, no. 20, August 5, 1905, p. 6, col. 1.

1905 "40 Mile Canyon," Beatty Bullfrog Miner, vol. 1, no. 21, August 12, 1905, p. 5 , col. 2.

1905 "Indian Powwow," Beatty Bullfrog Miner, vol. 1, no. 27, September 23, 1905, p. 1, col. 1.

1905 "Manse: White's Springs and Garden Spot in the Desert," Beatty Bullfrog Miner, vol. 1, no. 27, September 23, 1905, p. 3, col. 4.

1905 "Water Sources," Beatty Bullfrog Miner, vol. 1, no. 29, October 7, 1905, p. 2 , col. 2.

1905 "Shoshone: How the Great Mine was Discovered," Beatty Bullfrog Miner, vol. 1, no. 33, November 4, 1905, p. 1, col. 4.

1906 "Full Text of Judge Breen's Decision," Beatty Bullfrog Miner, vol. 1, no. 42, January 6, 1906, pp. 3-4.

1906 "Ash Meadows: Great Water Supply in Southern Nevada," Beatty Bullfrog Miner, vol. 1, no. 46, February 3, 1906, p. 3, col. 4.

1906 "The Great Transvaal Strike Near Beatty," Beatty Bullfrog Miner, vol. 2, no. 3 , April 7, 1906, p. 1, col. 1.

1906 "Gold Center, Nevada," Beatty Bullfrog Miner, vol. 2, no. 7, May 5, 1906, p. 1, col. 1.

1906 "Indian Rights," Beatty Bullfrog Miner, vol. 2, no. 7, May 5, 1906, p. 2, col. 2.

1906 "Forty Mile Canyon," Beatty Bullfrog Miner, vol. 2, no. 26, September 15, 1906, p. 9, col. 1.

1906 "Accidentally Shot," Beatty Bullfrog Miner, vol. 2, no. 27, September 22, 1906, p. 8 , col. 3.

1906 "Local" (local news items), Beatty Bullfrog Miner, vol. 2, no. 37, December 1, 1906, p. 12, col. 2. 
1906 Beatty Bullfrog Miner, vol. 2, no. 38, December 8, 1906, p. 12, col. 2.

1906 "Forty Mile," Beatty Bullfrog Miner, vol. 2, no. 40, December 22, 1906, p. 4, col. 2.

1906 "Forty Mile," Beatty Bulfrog Miner, vol. 2, no. 40, December 22, 1906, p. 12, col. 2.

1907 "Oak Springs," Beatty Bullfog Miner, vol. 2, no. 43, January 12, 1907, p. 3 , col. 4.

1907 "The Old Lead-Silver Mine of Forty Mile," Beatty Bullfrog Miner, vol. 2, no. 46, February 23, 1907, p. 2, col. 2.

1907 "Last of Piute Chiefs," Beatty Bullfrog Miner, vol. 2, no. 48, March 2, 1907, p. 4, col. 2.

1907 "The Old Mines of the District," Beatty Bulffrog Miner, vol. 2, no. 51, March 9, 1907, p. 9, col. 1.

1907 "Forty Mile," Beatty Bulfrog Miner, vol. 3, no. 14, June 29, 1907, p. 2, col. 2.

1907 "July Fourth," Beatty Bullfrog Miner, vol. 3, no. 15, July 6, 1907, p. 1, col. 2.

1907 "Johnnie," Beatty Bullfrog Miner, vol. 3, no. 27, September 28, 1907, p. 1, col. 3.

1907 "Shooting at Manse," Beatty Bullfrog Miner, vol. 3, no. 27, October 5, 1907, p. 3 , col. 2.

1907 "Bullfrogs" (local news), Beatty Bulfrog Miner, vol. 3, no. 40, December 28, 1907, p. 1, col. 2.

1908 "Hurrah for Bare Mountain and Beatty," Beatty Bulltrog Miner, vol. 4, no. 6, May 2, 1908, p. 2, col. 1.

1908 "Indians and Mining," Beatty Bullfrog Miner, vol. 4, no. 13, June 20, 1908, p. 4, col. 2.

1908 "Forty Mile," Beatty Búllfrog Miner, vol. 4, no. 27, September 26, 1908, p. 1, col. 2.

1908 "First White Man in Bulffrog Dead," Beatty Bullfrog Miner, vol. 4, no. 38, December 12, 1908, inside p., col. 5.

Belmont Courier

1891 "Ash Meadows, and the Great Amargosa and Ralston Deserts," Belmont Courier, vol. 18, no. 19, June 13, 1891, p. 2, col. 3.

1897 Belmont Courier, vol. 14, no. 46, December 10, 1897, p. 3, col. 1.

1899 "Local Jots," Belmont Courier, vol. 26, no. 46, December 9, 1899, p. 2, col. 2. 


\section{Bullfrog Miner}

1905 "Water, Pure and Plenty," Bullfrog Miner, vol. I, no. II, June 9, 1905, inside p., col. 3.

1906 "Frog Saddles" (local news items), Bullfrog Miner, vol. II, no. I, March 30, 1906, inside p., col. 3.

1906 Bullfrog Miner, vol. II, no. 2, April 6, 1906, p. 1, col. 1.

1906 "Iron Horse to Johnnie," Bullfrog Miner, vol. II, no. 9, May 25, 1906, p. 1, col. 3.

1906 "Killed by Lightning," Bullfrog Miner, vol. II, no. 18, July 27, 1906, inside p., col. 1.

1906 Bullfrog Miner, vol. II, no. 18, July 27, 1906, p. 2, col. 5.

1906 "Pocopah-New Camp," Bullfrog Miner, vol. II, no. 21, August 17, 1906, p. 6, col. 3.

1906 "Gold Bullfrog Buys Water," Bullfrog Miner, vol. II, no. 21, August 24, 1906, inside p., col. 2.

1906 "Panamint Joe Gets Message from Clouds," Bullfrog Miner, vol. II, no. 23, August 31, 1906, p. 1, col. 2.

1906 "Superstition of Panamint Joe," Bullfrog Miner, vol. II, no. 24, September 7, 1906, p. 3, col. 6.

1906 "Maude Beatty Shot by Brother," Bullfrog Miner, vol. II, no. 26, September 21, 1906, p. 5, col. 4.

1906 Bullfrog Miner, vol. II, ṇo. 26, September 21, 1906, p. 5, col. 5.

1906 Bullfrog Miner, vol. II, no. 28, October 5, 1906, p. 1, col. 1.

1906 Bullfrog Miner, vol. II, no. 34, November 16, 1906, inside p., col. 3.

1906 "Pocopah," Bullfrog Miner, vol. II, no. 39, December 21, 1906, p. 10, col. 6.

1906 "Pocopah," Bullfrog Miner, vol. II, no. 40, December 28, 1906, p. 10, col. 6.

1907 "Rhyolite's Three Good Water Systems," Bullfrog Miner, vol. III, no. 1, March 29,1907 , p. 7 , col. 2.

1907 Bullfrog Miner, vol. III, no. 1, March 29, 1907, p. 3, col. 1.

1907 "Work Started on the Ash Meadows Water System," Bullfrog Miner, vol. II, no. 9, May 24, 1907, p. 1, col. 1.

1907 Bullfrog Miner, vol. II, no. 9, May 24, 1907, p. 1, col. 1.

1907 "Poet Prospector Leads Party to Attact [sic] Redskins," Bullfrog Miner, vol. III, no. 10, May 31, 1907, inside p., col. 3.

1907 "Says 'Scotty' and Poet-Prospector are Four Flushers," Bullfrog Miner, vol. III, no. 11, June 8, 1907, inside p., col. 3. 
1907 Bullfrog Miner, vol. III, no. 12, June 15, 1907, inside p., col. 3, 5.

1907 "Another Comstock in the Panamint Range," Bullfrog Miner, vol. III, no. 15, July 6, 1907, p. 1, col. 3.

1907 Bullfrog Miner, vol. III, no. 24, September 7, 1907, p. 10, col. 5.

1907 Bullfrog Miner, vol. IV, no. 30, September 12, 1908, p. 6, col. 4.

1907 "Little Charlie Killed by Bad Man at Pahrump," Bullfrog Miner, vol. 3, no. 27, September 28, 1907, p. 10, col. 3.

1907 "Make Rich Discovery of Ore on Bare Mt.," Bullfrog Miner, vol. III, no. 29, November 9, 1907, inside p., col. 3.

1907 "Rhyolite's Water Companies," Bullfrog Miner, vol. III, no. 39, December 21, 1907, p. 7, col. 4.

1907 Bullfrog Miner, vol. III, no. 39, December 21, 1907, p. 14, col. 3.

1908 "Spring Goes Dry in Thirty Years," Bullfrog Miner, vol. III, no. 47, February 15, 1908, p. 5, col. 4.

1908 "Will Preserve Timber on U.S. Land," Bullfrog Miner, vol. III, no. 47, February 15, 1908, p. 1, col. 6.

1908 "Fluorine is the New Town," Bullfrog Miner, vol. IV, no. 4, April 18, 1908, p. 1, col. 6.

1908 "Ancient Indian Camp in the Funeral Range," Bullfrog Miner, vol. IV, no. 4, April 18, 1908, p. 5, col. 1.

1908 "Panamint Joe Gives War Dance at Bullfrog," Bullfrog Miner, vol. IV, no. 5, April 25, 1908, p. 8, col. 3.

1908 "Injun Man has Rich Mining Claims," Bullfrog Miner, vol. IV, no. 9, May 23, 1908, p. 1, col. 5.

1908 "Heap Old Injun Man has Good Locations," Bullfrog Miner, vol. IV, no. 12, June 13 , 1908, p. 5 , col. 3.

1908 Bullfrog Miner, vol. IV, no. 12, June 20, 1908, p. 8, col. 3.

1908 Bullfrog Miner, vol. IV, no. 14, June 27, 1908.

1908 Bullfrog Miner, vol. IV, no. 15, July 4, 1908, p. 6, col. 3.

1908 "Celebration on Fourth a Big Success," Bullfrog Miner, vol. IV, no. 16, July 11, 1908 , p. 5 , col. 3.

1908 Bullfrog Miner, vol. IV, no. 12, July 18, 1908, p. 2, col. 5.

1908 "No Heap Pine Nuts, No Heap Cold; No Heap Cold, Heap Hot," Bullfrog Miner, vol. IV, no. 18, July 25,1908, p. 8 , col. 1.

1908 "Injun Man' Says Mild Winter this Year," Bullfrog Miner, vol. IV, no. 30, September 12, 1908, p. 6, col. 4. 
1908 "Indian Murdered in Shoshone Camp," Bullfrog Miner, vol. IV, no. 29, October 17,1908, p. 8 , col. 5 .

1908 "First White Man in Bullfrog Dead," Bullfrog Miner, vol. IV, no. 38, December 19, 1908, p. 8, col. 5.

1909 Bullfrog Miner, vol. IV, no. 40, January 2, 1909, p. 6, col. 3.

1909 "Indian Suffers for Grafting Wagon," Bullfrog Miner, vol, V, no. 18, July 24, 1909, p. 4, col. 1.

Caliente Herald

1929 "Capt. Jack Mine is Believed Found," Caliente Herald, vol. 2, no. 4, January 31,1929, p. 1, col. 6.

\section{Carrara Obelisk}

1914 "Lost Mine: Legend for Forty Mile Canyon," Carrara Obelisk, vol. II, no. 1, May 8, 1914, p. 6, col. 3.

1915 "Selling Booze to Indians," Carrara Obelisk, vol. II, no. 24, April 17, 1915, p. 8, col. 2.

1915 "Jail the Indians Too," Carrara Obelisk, vol. II, no. 1, April 17, 1915, p. 8, col. 3.

1915 Local news column, Carrara Obelisk, vol. III, no. 4, November 27, 1915, p. 8, col. 1.

1915 Local news column, Carrara Obelisk, vol. III, no. 6, December 4, 1915, p. 8, col. 1.

Carson City News

1910 "Longstreet Killed Indian in Defense of His Own Life," Carson City News, vol. IX, no. 205, August 31, 1910, p. 1, col. 1.

Daily Nevada State Joumal

1891 "The Pahrump Mines," Daily Nevada State Journal, vol. 37, no. 28, May 1 , 1891, p. 2, col. 3.

1891 "The Montgomery Mines," Daily Nevada State Joumal, vol. 27, no. 58, June 5 , 1891 , p. 3, col. 2.

Goldfield News and Beatty Bulletin

1947 "Classy Pitching Duel Marks 3-2 Loss to Tonopah," Beatty Bulletin and Goldfield News, vol. 44, no. 12, August 1, 1947, p. 1, col. 7.

1947 "3 Indian Girls Unhurt by "Shots From Poison Bow," Goldfield News and Beatty Bulletin, vol. 44, no. 15, August 22, 1947, p. 1, col. 4.

1947 Goldfield News and Beatty Bulletin, vol. 44, no. 17, September 5, 1947, p. 1, col. 1.

1947 "Local Group to Explore 40 Mile Canyon District," Goldfield News and Beatty Bulletin, vol. 44, no. 18, September 12, 1947, p. 1, col. 6-7. 
1948 "Archeologist and Party in Survey of 40-Mile Country," Goldfield News and Beatty Bulletin, vol. 44, no. 50, April 23, 1948, p. 1, col. 6.

1948 Goldfield News and Beatty Bulletin, vol. 44, no. 48, April 29, 1948, p. 1, col. 4.

1949 "Danny Shoshone Flees Custody," Goldfield News and Beatty Bulletin, vol. 47, no. 1, May 13, 1949, p. 1, col. 1.

1949 "Early History of Pahrump, Death Valley Told in Letter," Goldfield News and Beatty Bulletin, vol. 47, no. 7, June 24, 1949, p. 1, col. 5.

1949 Goldfield News and Beatty Bulletin, vol. 47, no. 18, September 9, 1949.

1950 "Shoshone Rallies to Upset Beatty," Goldfield News and Beatty Bulletin, vol. 48 , no. 23, September 8, 1950, p. 1, col. 2.

1950 "Death Takes Bessie Shaw, Oldtime Beatty Resident," Goldfield News and Beatty Bulletin, vol. 48, no. 31, November 3, 1950, p. 1, col. 4.

1953 "Beatty Briefs," Beatty Bulletin and Goldfield News, vol. 50, no. 39, June 26, 1953 , p. 1, col. 2.

Goldfield Review

1905 "A Tough Indian," Goldfield Review, vol. 1, no. 38, July 13, 1905, p. 6, col. 2.

1905 "Piutes Hold Carnival at Grave of Chief Tecopa," Goldfield Review, vol. 1, no. 49, September 28, 1905, p. 2, col. 6.

Lincoln County Record

1901 "Smallpox," Lincoln County Record, January 11, 1901, p. 2, col. 1.

1903 "A Good Move," Lincoln County Record, vol. 54, no. 23, November 27, 1903, p. 4, col. 2.

1905 Lincoln County Record, January 11, 1901, p. 2, col. 3.

Nevada State Journal

1976 "In Old Nevada: Pahrump Valley's Horse Thieves," Nevada State Journal, March 7, 1976, p. 10, col. 1.

NTS (Nevada Test Site) News

1964 "Remembrances of Yesterday on the Test Site," NTS News, vol. VIII, no. 2, January 24, 1964, pp. 4-5.

1964 "Archaeological Salvage at the Test Site," NTS News, vol. VIII, no. 21, October 30, 1964, pp. 1,4-5,8.

1966 "The Lost Breyfogle Mine," NTS News, vol. IX, no. 3, February 4, 1966, p. 7.

1966 "Would You Believe Indian Springs?," NTS News, vol. IX, no. 16, August 5, 1966, p. 4-6,8. 
Pioche Daily Record

1873 "A Big Live Stock Enterprise," Pioche Daily Record, vol. 5, no. 143, March 4, 1873, p. 3, col. 3.

1873 Local news column, Pioche Daily Record, vol. 6, no. 4, March 21, 1873, p. 3 , col. 2.

1873 "Excitement over a Shoshone Squaw," Pioche Daily Record, vol. 6, no. 7, March 25, 1873, p. 3, col. 2.

1873 "The Great Mining Suit," Pioche Daily Record, vol. 6, no. 13, April 1, 1873, p. 3, col. 3.

1873 "Still Dying in the Sagebrush," Pioche Daily Record, vol. 6, no. 24, April 19, 1873 , p. 3, col. 1.

1874 Local news column, Pioche Daily Record, vol. 9, no. 77, December 17, 1874, p. 3, col. 1.

1875 Pioche Daily Record, vol. V, no. 143, October 3, 1875, p. 3, col. 2.

Pioche Weekly Record

1879 "Another Indian War," Pioche Weekly Record, vol. 17, no. 18, January 11, 1879 , p. 3 , col. 3.

1879 "Killed by Indians," Pioche Weekly Record, vol. 19, no. 6, October 25, 1879, p. 3 , col. 1.

1881 "Indian Killod," Pioche Weekly Record, January 29, 1881, p. 3, col. 1.

1882 "Another from Pahranagat," Pioche Weekly Record, vol. 24, no. 19, July 22 , 1882 , p. 3, col. 3.

1882 Local news column, Pioche Weekly Record, vol. 25, no. 5, October 14, 1882, inside p., col. 3.

1883 Local news column, Pioche Weekly Record, vol. 25, no. 19, January 20, 1883, inside p., col. 3.

1883 Local news column, Pioche Weekly Record, vol. 25, no. 21, February 3, 1883, p. 2, col. 3.

1883 Pioche Weekly Record, vol. 26, no. 1, March 7, 1883.

1.883 Local news column, Pioche Weekly Record, vol. 26, no. 4, April 7, 1883, p. 2 , col. 2.

1883 Local news column, Pioche Weekly Record, vol. 26, no. 5, April 14, 1883, p. 2, col. 2.

1883 "New Mines Discovered," Pioche Weekly Record, vol. 26, no. 14, June 16, 1883 , p. 3, col. 1.

1883 Local news column, Pioche Weekly Record, vol. 27, no. 2, September 22, 1883, p. 2 , col. 2. 
1883 Local news column, Pioche Weekly Record, vol. 27, no. 4, October 6, 1883, p. 2, col. 3.

1883 Local news column, Pioche Weekly Record, vol. 27, no. 7, October 27, 1883, p. 3, col. 2.

1884 Local news column, Pioche Weekly Record, vol. 27, no. 18, January 12, 1884, p. 2, col. 2.

1889 Local and state news column, Pioche Weekly Record, vol. 37, no. 6, April 20, 1889, p. 3, col. 1,4 .

1889 Local news column, Pioche Weekly Record, vol. 37, no. 8, May 4, 1889, p. 3, col. 4.

1889 Local news column, Pioche Weekly Record, vol. 37, no. 11, May 25, 1889, p. 3, col. 2.

1889 Local news column, Pioche Weekly Record, vol. 37, no. 16, June 29, 1889, p. 3, col. 3.

1889 Pioche Weekly Record, vol. 37, no. 17, July 6, 1889, p. 4.

1889 Local news column, Pioche Weekly Record, vol. 38, no. 1, September 21, 1889 , p. 3 , col. 3

1889 Local news column, Pioche Weekly Record, vol. 38, no. 14, December 21, 1889 , p. 4.

1890 Local news column, Pioche Weekly Record, vol. 38, no. 22, February 15, 1890, p. 3 , col. 3.

1890 Local news column, Pioche Weekly Record, vol. 39, no. 18, July 19, 1890, p. 3 , col. 1.

1890 Local news column, Pioche Weekly Record, vol. 40, no. 11, November 29 , 1890, p. 3, col. 2.

1890 "The Nye County Indian Trouble," "Naches on the Indian Scare," Pioche Weekly Record, vol. 40, no. 11, November 29, 1890, p. 3, col. 2.

1891 "Moving Indians," Pioche Weekly Record, vol. 40, no. 17, January 10, 1891, p. 3, col. 3.

1891 "A Sick Town," Pioche Weekly Record, vol. 40, no. 24, February 26, 1891, p. 3 , col. 2.

1891 Local news column, Pioche Weekly Record, vol. 40, no. 28, March 26, 1891, p. 4, col. 2.

1891 Local news column, Pioche Weekly Record, vol. 40, no. 32, April 23, 1891, p. 3, col. 2.

1891 Local news column, Pioche Weekly Record, vol. 40, no. 34, May 11, 1891, p. 4.

1891 "The Fourth: Order of Exercises," Pioche Weekly Record, vol. 40, no. 40, June 25, 1891, p. 4. 
1891 "The Fourth's Observance," Pioche Weekly Record, vol. 40, no. 42, July 9 , 1891 , p. 4.

1891 Local news column, Pioche Weekly Record, vol. 41, no. 7, October 29, 1891, p. 4, col. 1.

1895 "Shot Dead," Pioche Weekly Record, vol. 45, no. 11, December 5, 1895, p. 4, col. 3.

1895 "A Buckboard and Harness," Pioche Weekly Record, vol. 45, no. 12, December 12, 1895, p. 4, col. 3.

1896 "Riddled with Bullets," Pioche Weekly Record, vol. 45, no. 24, March 5, 1896, p. 4 , col. 2.

1903 Local news page, Pioche Weekly Record, vol. 54, no. 6, July 31, 1903, p. 4, col. 4.

Pioneer Topics

1909 "Pioneer Topics," (local news items), Pioneer Topics, vol. 1, no. 7, April 1, 1909, p. 1, col. 6.

Rhyolite Daily Bulletin

1907 "Indian Was Murdered," Rhyolite Daily Bulletin, vol. 1, no. 4, September 26, 1907, p. 1, col. 2.

1907 "Casey Got the Desperado," Rhyolite Daily Bulletin, vol. 1, no. 7, September 30,1907, p. 3, col. 1

1907 "Preliminary of Charles Clay," Rhyolite Daily Bulletin, vol. 1, no. 10, October 3, 1907, p. 1, col. 2.

1908 "Piute Indians Hold Pow Wow," Rhyolite Daily Bulletin, vol. 1, no. 178, April 20, 1908, p. 1, col. 3.

1908 "Indians Hold Another Powwow: Remnants of Noble Red Man Give Entertainment," Rhyolite Daily Bulletin, vol. 1, no. 228, October 7, 1908, p. 4, col. 1.

1908 "Beatty Ranch Case Has Been Decided Again," Rhyolite Daily Bulletin, vol. 1, no. 228 , October 7,1908, p. 1 , col. 3.

1908 "Duel to Death Between Enraged Indians," Rhyolite Daily Bulletin, vol. 1, 1908, October 13, 1908, p. 1, col. 1

1908 "Indians in Jail for Raising a Disturbance," Rhyolite Daily Bulletin, vol. 1, no. 294, December 26, 1908, p. 4, col. 1.

Rhyolite Herald

1905 "In Beatty District," Rhyolite Herald, vol. I, no. 12, July 21, 1905, p. 1, col. 1.

1905 Rhyolite Herald, vol. 1, no. 19, September 8, 1905.

1905 "Resources of the Fertile Oasis Valley," Rhyolite Herald, vol. I, no. 19, September 8, 1905, p. 1, col. 1.

1906 "Grubstake Suit Ended," Rhyolite Herald, vol. I, no. 36, January 5, 1906, p. 1, col. 3. 
Rhyolite Herald, vol. 1, no. 36, January 5, 1906, p. 1.

1906 "Water in Plenty: Oasis Valley," Rhyolite Herald, vol. II, no. 8, June 22, 1906, inside p., col. 3.

1906 "Pocopah The Latest," Rhyolite Herald, vol. II, no. 16, August 17, 1906, inside p., col. 5.

1906 "Bare Mountain's Prospects and Possibilities," Rhyolite Herald, vol. II, no. 15, August 10, 1906, inside p., col. 5.

1906 "The Other Railroads Pushing Work Toward Rhyolite," Rhyolite Herald, vol. II, no. 34, December 21, 1906, p. 1, col. 5 .

1906 "Rhyolite Freight Yards Taxed to the Limit," Rhyolite Herald, vol. II, no. 35, December 28, 1906, inside p., col. 5.

1907 "From Ash Meadows to Greenwater," Rhyolite Herald, vol. II, no. 40, February 1, 1907, inside p., col. 3.

1907 Rhyolite Herald, vol. 4, no. 2, May 6, 1908, inside p., col. 6.

1908 Rhyolite Herald, vol. 4, no. 4, May 20, 1908, inside p., col. 1.

1908 "Plans for the Fourth," Rhyolite Herald, vol. IV, no. 8, June 17, 1908, p. 5, col. 5.

1908 Rhyolite Herald, vol. IV, no. 9, June 24, 1908, p. 7.

1908 "Program for Fourth of July," Rhyolite Herald, vol. IV, no. 10, July 1, 1908, p. 10, col. 4.

1908 "Celebration was a Big Success," Rhyolite Herald, vol. IV, no. 11, July 8, 1908, inside p. 1, col. 3.

1908 Rhyolite Herald, vol. IV, no. 16, August 13, 1908.

1908 "Good Strike Near 40-Mile Canyon," Rhyolite Herald, vol. IV, no. 34, December 16, 1908, inside p., col. 1.

1908 "The Last of the Squaw Men," Rhyolite Herald, vol. IV, no. 34, December 16, 1908, inside p., col. 3.

1909 "Springdale, Gateway from the North," Rhyolite Herald Pictorial Edition, Midwinter Supplement, March 1909.

1909 "Indian Henry Killed by John Scott," Rhyolite Herald, vol. V, no. 3, July 24, 1909 , p. 1, col. 3.

1909 "Red Man's Friend: Millionaire Montgomery Pensions the Copper Colored Heroine of the Panamints," Rhyolite Herald, vol. V, no. 13, July 24, 1909, inside p., col. 4.

1909 "Agricultural Paradise in Amargosa Valley," Rhyolite Herald, vol. V, no. 19, September 4, 1909, inside p., col. 2. 
1909 "Pahrump Valley is Prize Winner," Rhyolite Herald, vol. V, no. 21, September 18, 1901, p. 1, col. 2.

1909 "Maggie the Heroine Loves Whiskey," Rhyolite Herald, vol. V, no. 21, September 18, 1909, p. 2, col. 3.

1909 "Heroine or Holdup," Rhyolite Herald, vol. V, no. 25, October 18, 1909, inside p., col. 3.

1910 "Telluride Camp Shows More Ore," Rhyolite Herald, vol. V, no. 51, April 16, 1910, p. 1, col. 3.

1910 "Oh You Watermelon," Rhyolite Herald, vol. VI, no. 17, August 20, 1910, p. 1, col. 6.

1912 "Shooting at Wood Camp," Rhyolite Herald, vol. VII, no. 37, January 13, 1912, p. 1, col. 4.

1912 Rhyolite Herald, vol. VII, no. 41, March 9, 1912, inside p., col. 1.

1912 Rhyolite Herald, vol. VII, no. 43, March 23, 1912, inside p., col. 6.

1912 Rhyolite Herald, vol. VII, no. 44, March 30, 1912, inside p., col. 1.

San Francisco Examiner

1891 "We Have the Ghost Dance," San Francisco Examiner, vol. LII, no. 11, January 11,1891 , p. 4, col. 1.

Searchlight (Searchlight, California)

1903 Searchlight, vol. 2, no. 4, July 3, 1903, p. 6, col. 2.

1903 Searchlight, vol. 2, no. 23, November 8, 1903, p. 3, col. 6.

1903 "Bad Feelings Among Indians," Searchlight, vol. 2, no. 28, December 18, 1903, p. 1, col. 4.

1904 "Two Prospectors Murdered," Searchlight, vol. 2, no. 31, January 8, 1904, p. 1, col. 4.

Tonopah Daily Sun

1905 "Unknown Man Killed in Squaw Camp Near Lida," Tonopah Daily Sun, March 21, 1905, p. 1, col. 3.

1905 "Indian's Absence Still Clogs Wheels of Justice," Tonopah Daily Sun, vol. I, no. 269, November 13, 1905, p. 1, col. 5 .

1905 "Judge Breen to Probe into Cause of Indian's Flight," Tonopah Daily Sun, vol. I, no. 269 , November 13, 1905, p. 1, col. 3 .

1905 "Missing Indian Witness Ties Up Big Mining Suit," Tonopah Daily Sun, vol. I, no. 269 , November 13, 1905, inside p., col. 1.

1906 "Rich Ore from Indian Reservation," Tonopah Daily Sun, February 2, 1906, inside p., col. 2. 
1906 "Squaw Causes Gun Fight Between Indians," Tonopah Daily Sun, March 29 , 1906, inside p., col. 1.

1906 "Order of the Grand Parade," Tonopah Daily Sun, Juty 3, 1906, inside p., col. 3.

1906 "Indians Will Join in Celebration," Tonopah Daily Sun, July 3, 1906, inside p., col. 4.

1906 "Indians Will Locate Claims," Tonopah Daily Sun, October 20, 1906, p. 1, col. 5.

1906 "Piute Indians Give a Big Dance," Tonopah Daily Sun, November 26, 1906, inside P., col. 1.

Tonopah Daily Times and Bonanza

1933 "Boys Say Camp Life Picking Up at Charleston," Tonopah Daily Times and Bonanza, vol. 18, no. 183, June 16, 1933, p. 1, col. 1.

1933 "Piutes Install New Chieftain at Tribe Ceremonial," Tonopah Daily Timos and Bonanza, October 4, 1933, p. 4, col. 1.

Tonopah Miner

1903 Tonopah Miner, vol. II, no. 4, July 11, 1903, inside p., col. 3.

1903 Tonopah Miner, vol. II, no. 10, August 22, 1903, p. 3, col. 1.

1903 Tonopah Miner, vol. II, no. 18, October 17, 1903, p. 2, col. 2

1904 Tonopah Miner, vol. II, no. 32, January 30, 1904, p. 6, col. 2.

1904 "The Fourth at Goldfield," Tonopah Miner, vol. III, no. 3, July 2, 1904, inside p., col. 2.

1904 Tonopah Miner, vol. IV, no. 5, July 15, 1905, p. 6, col. 4.

1904 Tonopah Miner, vol. III, no. 29, December 31, 1904, p. 1, col. 1.

1905 Water Plenty: Engineer Philbrick Reports the Goss Springs Supply to be Pure and Amply Sufficient," Tonopah Miner, vol. IV, no. 1, June 17, 1905, p. 6, cot. 1.

1905 "The Pioneer of Bulfrog," Tonopah Miner, vol. IV, no. 5, July 15, 1905, p. 6, col. 4 .

1905 "Perished in Death Valley," Tonopah Miner, vol. N, no. 13, September 9, 1905, p. 7 , col. 2.

1905 Tonopah Miner, vol. IV, no. 16, September 30, 1905, p. 1.

1905 Tonopah Miner, vol. IV, no. 21, November 4, 1905, p. 2, col. 1.

1905 Tonopah Miner, vol. IV, no. 22, November 11, 1905, p. 1, col. 1.

1905 "Gold Center: Another Bullfrog Town that is Rapidly Coming to the Front," Tonopah Miner, vol. IV, no. 29, December 30, 1905, p. 10, col. 1. 
Tonopah Nining Reporter

1922 "Southern End of Nye County Very Active," Tonopah Mining Reporter, vol. 1, no. 39, May 27, 1932, p. 1, col. 7.

1922 "July Fourth Entertainment is Completed," Tonopah Mining Reporter, June 24, 1922, inside p., col. 3.

1922 "Taking Census Population of Nye Redskins," Tonopah Mining Reporter, vol. II, no. 12 , November 18, 1922, p. 1, col. 3.

1923 "Beatty Plans Big Barbeque Fourth July," Tonopah Mining Reporter, vol. 1, no. 44, July 1, 1923, p. 2, col. 7.

1923 "Choice Nye Land Thrown Open to Ex Soldiers," Tonopah Mining Reporter, vol. II, no. 45 , July 7,1923, p. 1, col. 2.

1923 "Mining Active in South Nevada," Tonopah Mining Reporter, vol. III, no. 14, December 1, 1923, p. 1, col. 6.

1924 "Indian Puts Bullet into his Relative," Tonopah Mining Reporter, vol. III, no. 27, May 10, 1924, p. 4, col. 6.

1924 "Indian Pleads Guilty to Charge," Tonopah Mining Reporter, vol. III, no. 38, May 17, 1924, p. 2, col. 5.

1924 "Congress Mine at Johnnie to be Opened Now," Tonopah Mining Reporter, vol. IV, no. 3, September 20, 1924, p. 2, col. 4.

1926 "Beatty Region Now Booming Reports Show," Tonopah Mining Reporter, vol. IV, no. 40, January 9, 1926, inside p., col. 4.

1926 "Shoshones to Open Fandango," Tonopah Mining Reporter, vol. IV, no. 46, August 28, 1926, p. 2, col. 4.

1928 "Jack longstreet, Real'Pioneer, Dies at Hospital in Tonopah," Tonopah Mining Reporter, vol. 6, no. 46, July 28, 1928, p. 4, col. 6.

1928 "Jack Longstreet, Real Pioneer, Dies in Tonopah Hospital," Tonopah Mining Reporter, vol. 6, no. 46, July 28, 1928, p. 4, col. 6.

Tonopah Sun

1910 "Shoshone Squaw Beaten Up By Piutes," Tonopah Sun, vol. VI, no. 18, January 21, 1910, p. 1, col. 4.

1910 "Booze to Indians Causes Trouble," Tonopah Sun, vol. VI, no. 101, April 20, 1910, p. 1, col. 1.

Tonopah Times-Bonanza and Goldfield News

1968 "Fellow Otficers Honor Gilbert Landis," Tonopah Times-Bonanza and Goldfield News, July 5, 1968, p. 4, col. 1. 